\title{
Nickel-Catalyzed Cyanation of Unactivated Alkyl Sulfonates with $\mathrm{Zn}(\mathrm{CN})_{2}$
}

Aiyou Xia, Peizhuo Lv, Xin Xie and Yuanhong Liu*

State Key Laboratory of Organometallic Chemistry, Center for Excellence in Molecular Synthesis, Shanghai Institute of Organic Chemistry, University of Chinese Academy of Sciences, Chinese Academy of Sciences, 345 Lingling Lu, Shanghai 200032, People's Republic of China Fax: (+86) 021-64166128, E-mail:yhliu@sioc.ac.cn

\section{Contents:}

General Methods

Synthesis of 1a-Ac, 1a-Bz, 1a-Ts and 1a with different protecting groups S3

General procedure A for the synthesis of alkyl mesylates from alcohols S7

General procedure B for the synthesis of alkyl mesylates from ketones

Reaction of 1a under the standard conditions for alkyl halides reported in our previous paper

1) Reaction of 1a under the standard conditions for alkyl chlorides reported in our previous paper

2) Reaction of 1a under standard conditions for alkyl bromides reported in our previous paper

Optimization studies for cyanation of secondary alkyl mesylates

Nickel-catalyzed cyanation of secondary alkyl mesylates: synthesis of $\mathbf{2}$

Reaction of 3a under the standard conditions for alkyl halides reported in our previous paper 
2) Reaction of $\mathbf{1 a}$ in the presence of $\mathrm{Zn}(\mathrm{CN})_{2}$ with or without $n$-Bu $4 \mathrm{NI}$

3) Reaction of $\mathbf{3 a}$ under the standard conditions for alkyl mesylates

4) Portionwise addition of 3a under the standard conditions for alkyl mesylates

S52

5) Reaction of $1 \mathrm{a}$ under the standard reaction conditions for $1 \mathrm{~h}$

S52

6) Reaction of $1 \mathrm{a}$ with $\mathrm{Zn}(\mathrm{CN})_{2}$ in the presence of radical scavengers

NMR spectra

\section{General Methods.}

Unless noted, all reactions were carried out using a dry box technique under a nitrogen atmosphere. Tetrahydrofuran and toluene were distilled from sodium and benzophenone. 1,4Dioxane was distilled from sodium. $\mathrm{MeCN}$ was dried using Innovative Technology Solvent Purifier. $N, N$-Dimethylformamide, XantPhos, dppf, $\mathrm{PCy}_{3}, n$-Bu $\mathrm{Bu}_{4}, \mathrm{Et}_{4} \mathrm{NI}$ and $\mathrm{Cs}_{2} \mathrm{CO}_{3}$ were purchased from $\mathrm{J} \& \mathrm{~K}$ Chemical Company. $\mathrm{NiCl}_{2} \cdot 6 \mathrm{H}_{2} \mathrm{O}, \mathrm{Mn}, 4$-aminopyridine and $\mathrm{DABCO}$ (triethylene diamine) were purchased from Alfa Aesar. $\mathrm{NiCl}_{2}(\mathrm{DME}), \mathrm{NiI}_{2}$ and $\mathrm{NiXantPhos}$ were purchased from Strem. $\mathrm{NiCl}_{2}$, DMAP, $n-\mathrm{Bu} 4 \mathrm{NCl}$ and $n-\mathrm{Bu}_{4} \mathrm{NBr}$ were purchased from TCI. 2,2'-Bipyridine was purchased from Acros. Zinc powder (99\% metals basis, 325 mesh) was purchased from Adamas. Before using, zinc powder was stirred with $1 \mathrm{M} \mathrm{HCl}$ aqueous solution, filtered and washed thoroughly with water, acetone and diethyl ether and dried under vacuum. Unless otherwise noted, all other reagents were purchased from commercial sources. 4-iodo1-tosylpiperidine (3a) was prepared according to the published method. ${ }^{1}$

${ }^{1} \mathrm{H}$ and ${ }^{13} \mathrm{C}$ NMR spectra were recorded at room temperature in $\mathrm{CDCl}_{3}$ (containing $0.03 \%$ TMS) solutions on Varian or Agilent XL-400 MHz spectrometer. ${ }^{1} \mathrm{H}$ NMR spectra was recorded with tetramethylsilane $(0.00 \mathrm{ppm})$ or solvent residual peak $\left(\mathrm{CDCl}_{3}: 7.26 \mathrm{ppm}\right)$ as internal reference; ${ }^{13} \mathrm{C}$ NMR spectra was recorded with $\mathrm{CDCl}_{3}(77.00 \mathrm{ppm})$ as internal reference. High-resolution mass spectra were obtained by using Waters Micromass GCT Premier or Agilent Technologies 6224 TOF LC/MS. The IR spectra were measured on a ThermoFisher Nicolet FT-IR spectrometer. 


\section{Synthesis of 1a-Ac, 1a-Bz, 1a-Ts and 1a with different protecting groups}

\section{Synthesis of s-1a}

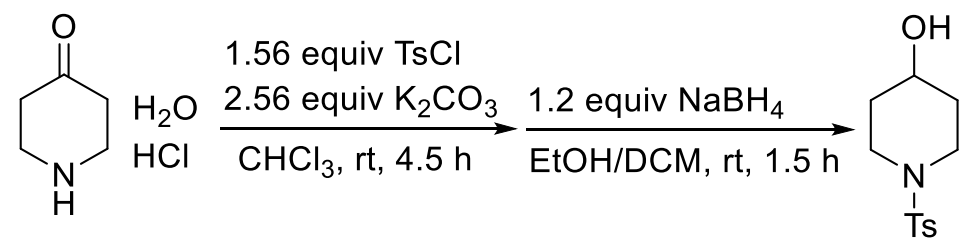

To a solution of 4,4-piperidinediol hydrochloride (1.54 g, $10 \mathrm{mmol}$ ), $\mathrm{K}_{2} \mathrm{CO}_{3}$ (3.54 g, 25.6 mmol) in $\mathrm{CHCl}_{3}(12 \mathrm{~mL})$ and $\mathrm{H}_{2} \mathrm{O}(12 \mathrm{~mL})$ was added $\mathrm{TsCl}(2.97 \mathrm{~g}, 15.6 \mathrm{mmol})$ at room temperature under air. The mixture was stirred at room temperature for $4.5 \mathrm{~h}$. After the starting material was completely consumed, the mixture was quenched with saturated $\mathrm{NaHCO}_{3}$ solution, extracted with $\mathrm{CH}_{2} \mathrm{Cl}_{2}$, dried over anhydrous $\mathrm{Na}_{2} \mathrm{SO}_{4}$. The solvent was evaporated under the reduced pressure and the residue was purified by column chromatography on silica gel (eluent: petroleum ether: dichloromethane $=2: 1$ to dichloromethane) to afford the white solid which was used for the next step.

To a solution of the product above in EtOH $(20 \mathrm{~mL})$ and $\mathrm{CH}_{2} \mathrm{Cl}_{2}(20 \mathrm{~mL})$ was added $\mathrm{NaBH}_{4}(454.0 \mathrm{mg}, 12 \mathrm{mmol})$ at room temperature under air. The mixture was stirred at room temperature for $1.5 \mathrm{~h}$. After the starting material was completely consumed, the mixture was quenched with saturated $\mathrm{NH}_{4} \mathrm{Cl}$ solution. The mixture was then evaporated under the reduced pressure to remove most of EtOH, extracted with $\mathrm{CH}_{2} \mathrm{Cl}_{2}$, dried over anhydrous $\mathrm{Na}_{2} \mathrm{SO}_{4}$. The solvent was evaporated under the reduced pressure and the residue was purified by column chromatography on silica gel (eluent: dichloromethane: ethyl acetate $=3: 1$ ) to afford 1tosylpiperidin-4-ol (s-1a) in 63\% isolated yield (1.61 g) as a white solid. ${ }^{1} \mathrm{H}$ NMR (400 MHz, $\left.\mathrm{CDCl}_{3}\right) \delta 7.62(\mathrm{~d}, J=8.0 \mathrm{~Hz}, 2 \mathrm{H}), 7.32(\mathrm{~d}, J=8.4 \mathrm{~Hz}, 2 \mathrm{H}), 3.71(\mathrm{~s}, 1 \mathrm{H}), 3.33-3.27(\mathrm{~m}, 2 \mathrm{H})$, 2.82-2.76 (m, 2H), 2.43 (s, 3H), 2.07 (bs, 1H), 1.92-1.86 (m, 2H), 1.67-1.58 (m, 2H); ${ }^{13} \mathrm{C} \mathrm{NMR}$ $\left(100 \mathrm{MHz}, \mathrm{CDCl}_{3}\right) \delta 143.5,132.9,129.6,127.5,65.7,43.2,33.1,21.4$. The spectroscopic data is in agreement with that previously reported. ${ }^{2}$ 


\section{Synthesis of 1a-Ac}

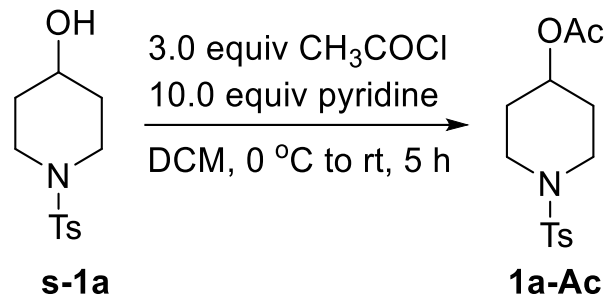

To a solution of s-1a $(766.0 \mathrm{mg}, 3 \mathrm{mmol})$ in $\mathrm{CH}_{2} \mathrm{Cl}_{2}(10 \mathrm{~mL})$ was added pyridine $(2.4 \mathrm{~mL}$, $30 \mathrm{mmol}$ ) at room temperature under air. The reaction mixture was then cooled down to $0{ }^{\circ} \mathrm{C}$ and acetyl chloride $(0.64 \mathrm{~mL}, 9 \mathrm{mmol})$ was then added to the mixture. The mixture was warmed to room temperature and stirred for $5 \mathrm{~h}$ at room temperature. After the starting material was completely consumed, the mixture was quenched with water, extracted with $\mathrm{CH}_{2} \mathrm{Cl}_{2}$, washed with $1 \mathrm{M} \mathrm{HCl}$ and brine, dried over anhydrous $\mathrm{Na}_{2} \mathrm{SO}_{4}$. The solvent was evaporated under the reduced pressure and the residue was purified by column chromatography on silica gel (eluent: petroleum ether: dichloromethane $=1: 2$ to dichloromethane: ethyl acetate $=5: 1$ ) to afford 1tosylpiperidin-4-yl acetate (1a-Ac) in 77\% isolated yield $(683.1 \mathrm{mg})$ as a white solid. M.p. 157$159{ }^{\circ} \mathrm{C} .{ }^{1} \mathrm{H}$ NMR $\left(400 \mathrm{MHz}, \mathrm{CDCl}_{3}\right) \delta 7.65(\mathrm{~d}, J=8.4 \mathrm{~Hz}, 2 \mathrm{H}), 7.34(\mathrm{~d}, J=8.4 \mathrm{~Hz}, 2 \mathrm{H}), 4.77-$ $4.72(\mathrm{~m}, 1 \mathrm{H}), 3.34-3.29(\mathrm{~m}, 2 \mathrm{H}), 2.90-2.84(\mathrm{~m}, 2 \mathrm{H}), 2.45(\mathrm{~s}, 3 \mathrm{H}), 2.00(\mathrm{~s}, 3 \mathrm{H}), 1.98-1.91(\mathrm{~m}$, 2H), 1.80-1.71 (m, 2H); $\left.{ }^{13} \mathrm{C} \mathrm{NMR} \mathrm{(100} \mathrm{MHz,} \mathrm{CDCl}_{3}\right) \delta 170.2,143.6,133.1,129.7,127.6,68.4$, 43.4, 30.0, 21.5, 21.1. IR (neat): 2930, 1726, 1338, 1310, 1246, 1161, 1094, 1028, 977, 934, 896, 844, 816, $724 \mathrm{~cm}^{-1}$. HRMS (ESI-TOF) m/z: $[\mathrm{M}+\mathrm{Na}]^{+}$calcd for $\mathrm{C}_{14} \mathrm{H}_{19} \mathrm{NO}_{4} \mathrm{NaS} 320.0927$; found 320.0927 .

\section{Synthesis of $1 \mathrm{a}-\mathrm{Bz}$}

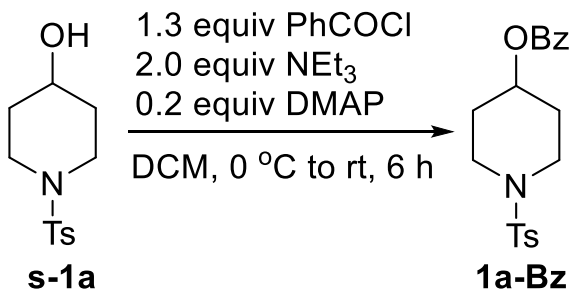

To a solution of s-1a (766.0 mg, $3 \mathrm{mmol})$ and DMAP $(73.3 \mathrm{mg}, 0.6 \mathrm{mmol})$ in $\mathrm{CH}_{2} \mathrm{Cl}_{2}(10$ $\mathrm{mL})$ was added $\mathrm{NEt}_{3}(0.83 \mathrm{~mL}, 6 \mathrm{mmol})$ at room temperature under argon. The mixture was then placed at $0{ }^{\circ} \mathrm{C}$ and benzoyl chloride $(0.45 \mathrm{~mL}, 3.9 \mathrm{mmol})$ was then added to the mixture. The mixture was warmed to room temperature and stirred for $6 \mathrm{~h}$ at room temperature. After 
the starting material was completely consumed, the mixture was quenched with saturated $\mathrm{NH}_{4} \mathrm{Cl}$ solution, extracted with $\mathrm{CH}_{2} \mathrm{Cl}_{2}$, washed with brine, dried over anhydrous $\mathrm{Na}_{2} \mathrm{SO}_{4}$. The solvent was evaporated under the reduced pressure and the residue was purified by column chromatography on silica gel (eluent: petroleum ether: dichloromethane $=1: 1$ to $1: 4$ ) to afford 1-tosylpiperidin-4-yl benzoate (1a-Bz) in $88 \%$ isolated yield $(946.7 \mathrm{mg})$ as a white solid. M.p. 179-181 ${ }^{\circ} \mathrm{C} .{ }^{1} \mathrm{H}$ NMR $\left(400 \mathrm{MHz}, \mathrm{CDCl}_{3}\right) \delta 7.92(\mathrm{~d}, J=8.4 \mathrm{~Hz}, 2 \mathrm{H}), 7.68(\mathrm{~d}, J=8.0 \mathrm{~Hz}, 2 \mathrm{H})$, $7.55(\mathrm{t}, J=7.6 \mathrm{~Hz}, 1 \mathrm{H}), 7.40(\mathrm{t}, J=8.0 \mathrm{~Hz}, 2 \mathrm{H}), 7.35(\mathrm{~d}, J=8.0 \mathrm{~Hz}, 2 \mathrm{H}), 5.05-4.99(\mathrm{~m}, 1 \mathrm{H})$, 3.39-3.33 (m, 2H), 3.02-2.97 (m, 2H), 2.45 (s, 3H), 2.09-2.04 (m, 2H), 1.96-1.88 (m, 2H); ${ }^{13} \mathrm{C}$ NMR $\left(100 \mathrm{MHz}, \mathrm{CDCl}_{3}\right) \delta 165.5,143.6,133.0,130.0,129.6,129.4,128.3,127.6,68.8,43.3$, 30.0, 21.5. IR (neat): 1715, 1448, 1334, 1299, 1276, 1163, 1155, 1021, 932, 816, 714, $651 \mathrm{~cm}^{-}$ 1. HRMS (ESI-TOF) m/z: [M+Na] $]^{+}$calcd for $\mathrm{C}_{19} \mathrm{H}_{21} \mathrm{NO}_{4} \mathrm{NaS} 382.1084$; found 382.1075.

\section{Synthesis of 1a-Ts}

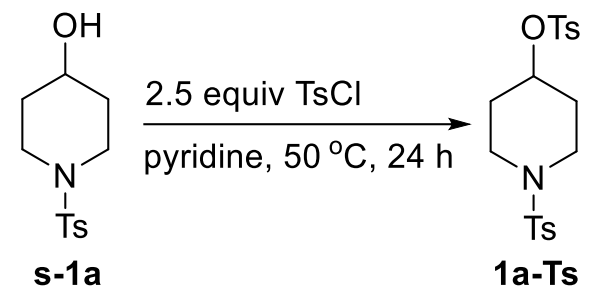

To a solution of $\mathrm{TsCl}(4.76 \mathrm{~g}, 25 \mathrm{mmol})$ in pyridine $(40 \mathrm{~mL})$ was added s-1a $(2.55 \mathrm{~g}, 10$ $\mathrm{mmol}$ ) at room temperature under air. The mixture was heated to $50{ }^{\circ} \mathrm{C}$ (oil bath) and stirred for $24 \mathrm{~h}$. After the starting material was completely consumed, the mixture was quenched with water. When most pyridine was evaporated under the reduced pressure, the residue was quenched with $1 \mathrm{M} \mathrm{HCl}$, extracted with $\mathrm{CH}_{2} \mathrm{Cl}_{2}$, dried over anhydrous $\mathrm{Na}_{2} \mathrm{SO}_{4}$. The solvent was evaporated under the reduced pressure and the residue was purified by column chromatography on silica gel (eluent: petroleum ether: ethyl acetate $=2: 1$ to 1:1) to afford 1-tosylpiperidin-4-yl 4-methylbenzenesulfonate (1a-Ts) in $86 \%$ isolated yield $(3.51 \mathrm{~g})$ as a white solid. ${ }^{1} \mathrm{H}$ NMR $\left(400 \mathrm{MHz}, \mathrm{CDCl}_{3}\right) \delta 7.71(\mathrm{~d}, J=8.0 \mathrm{~Hz}, 2 \mathrm{H}), 7.61(\mathrm{~d}, J=8.4 \mathrm{~Hz}, 2 \mathrm{H}), 7.34-7.30(\mathrm{~m}, 4 \mathrm{H})$, 4.53-4.50 (m, 1H), 3.14-2.98 (m, 4H), 2.44 (s, 3H), 2.43 (s, 3H), 1.90-1.71 (m, 4H); ${ }^{13} \mathrm{C}$ NMR $\left(100 \mathrm{MHz}, \mathrm{CDCl}_{3}\right) \delta 144.9,143.8,133.7,132.9,129.9,129.7,127.5,127.5,75.9,42.2,30.5$, $21.5,21.4$. The spectroscopic data is in agreement with that previously reported. ${ }^{3}$ 


\section{Synthesis of 1a}

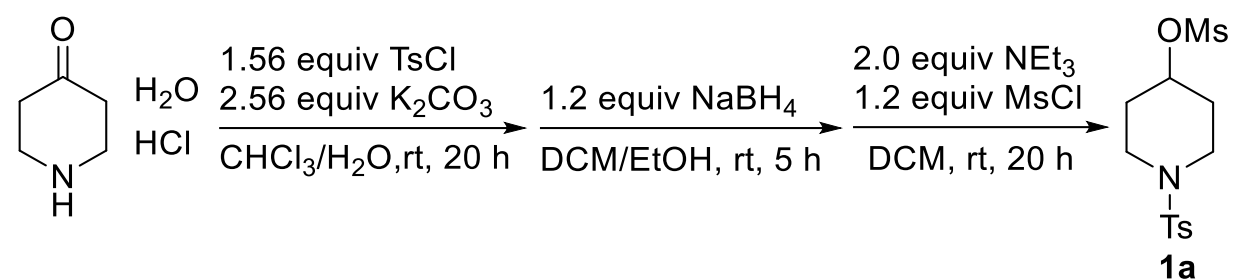

To a solution of 4,4-piperidinediol hydrochloride (3.8 g, $25 \mathrm{mmol}), \mathrm{K}_{2} \mathrm{CO}_{3} \quad(8.8 \mathrm{~g}, 64$ mmol) in $\mathrm{H}_{2} \mathrm{O}(30 \mathrm{~mL})$ and $\mathrm{CHCl}_{3}(30 \mathrm{~mL})$ was added $\mathrm{TsCl}(7.4 \mathrm{~g}, 39 \mathrm{mmol})$ at room temperature under air. After stirring for $20 \mathrm{~h}$, the mixture was extracted with $\mathrm{CH}_{2} \mathrm{Cl}_{2}$, dried over anhydrous $\mathrm{Na}_{2} \mathrm{SO}_{4}$. The solvent was evaporated under the reduced pressure and the residue was purified by column chromatography on silica gel (eluent: petroleum ether: dichloromethane $=2: 1$ to dichloromethane) to afford a white solid which was used for the next step.

To a solution of the above product in $\mathrm{CH}_{2} \mathrm{Cl}_{2}(50 \mathrm{~mL})$ and $\mathrm{EtOH}(50 \mathrm{~mL})$ was added $\mathrm{NaBH}_{4}(1.13 \mathrm{~g}, 30 \mathrm{mmol})$ by four portions in $15 \mathrm{~min}$ at room temperature under air. The mixture was stirred at room temperature for $5 \mathrm{~h}$. After the starting material was completely consumed, the mixture was quenched with saturated $\mathrm{NH}_{4} \mathrm{Cl}$ solution. When most EtOH was evaporated under the reduced pressure, the residue was extracted with $\mathrm{CH}_{2} \mathrm{Cl}_{2}$, dried over anhydrous $\mathrm{Na}_{2} \mathrm{SO}_{4}$. The solvent was evaporated under the reduced pressure and the residue was purified by column chromatography on silica gel (eluent: dichloromethane to dichloromethane: ethyl acetate $=4: 1$ ) to afford the white solid which was used for the next step.

To a solution of the above product in $\mathrm{CH}_{2} \mathrm{Cl}_{2}(50 \mathrm{~mL})$ were added $\mathrm{NEt}_{3}(6.9 \mathrm{~mL}, 50 \mathrm{mmol})$ and $\mathrm{MsCl}(2.3 \mathrm{~mL}, 30 \mathrm{mmol})$ separately at room temperature under air. The mixture was stirred for $20 \mathrm{~h}$ at room temperature. After the starting material was completely consumed, the mixture was quenched with saturated $\mathrm{NH}_{4} \mathrm{Cl}$ solution, extracted with $\mathrm{CH}_{2} \mathrm{Cl}_{2}$, dried over anhydrous $\mathrm{Na}_{2} \mathrm{SO}_{4}$. The solvent was evaporated under the reduced pressure and the residue was purified by column chromatography on silica gel (eluent: petroleum ether: dichloromethane $=1: 1$ to dichloromethane to dichloromethane: ethyl acetate $=10: 1)$ to afford 1-tosylpiperidin-4-yl methanesulfonate (1a) in $89 \%$ isolated yield $(7.42 \mathrm{~g})$ as a white solid. M.p. $175-177{ }^{\circ} \mathrm{C} .{ }^{1} \mathrm{H}$ NMR (400 MHz, $\left.\mathrm{CDCl}_{3}\right) \delta 7.64(\mathrm{~d}, J=8.4 \mathrm{~Hz}, 2 \mathrm{H}), 7.34$ (d, $\left.J=8.4 \mathrm{~Hz}, 2 \mathrm{H}\right), 4.79-4.74$ (m, 1H), 3.17-3.08 (m, 4H), 2.98 (s, 3H), 2.45 (s, 3H), 2.10-1.94 (m, 4H); ${ }^{13} \mathrm{C}$ NMR (100 MHz, 
CDCl3) $\delta 143.8,132.8,129.8,127.5,75.6,42.4,38.5,30.9,21.5$. IR (neat): 1335, 1325, 1309, 1244, 1170, 1160, 1092, 949, 932, 816, 727, 708 IR (neat): 1715, 1448, 1334, 1299, 1276, 1163 , 1155, 1021, 932, 816, 714, $651 \mathrm{~cm}^{-1}$. HRMS (ESI-TOF) $\mathrm{m} / \mathrm{z}:[\mathrm{M}+\mathrm{Na}]^{+}$calcd for $\mathrm{C}_{13} \mathrm{H}_{19} \mathrm{NO}_{5} \mathrm{NaS}_{2} 356.0597$; found 356.0601.

\section{General procedure A for the synthesis of alkyl mesylates from alcohols}

Typical procedure for the synthesis of $\mathbf{1 c}$.

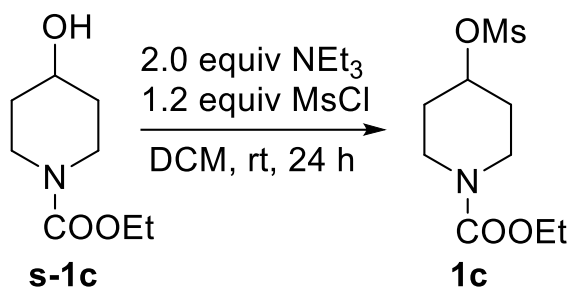

To a solution of s-1c $(1.73 \mathrm{~g}, 10 \mathrm{mmol})$ in $\mathrm{CH}_{2} \mathrm{Cl}_{2}(20 \mathrm{~mL})$ were added $\mathrm{NEt}_{3}(2.78 \mathrm{~mL}, 20$ $\mathrm{mmol})$ and $\mathrm{MsCl}(0.93 \mathrm{~mL}, 12 \mathrm{mmol})$ at room temperature under air. The mixture was stirred for $24 \mathrm{~h}$ at room temperature. After the starting material was completely consumed, the mixture was quenched with saturated $\mathrm{NH}_{4} \mathrm{Cl}$ solution, extracted with $\mathrm{CH}_{2} \mathrm{Cl}_{2}$, dried over anhydrous $\mathrm{Na}_{2} \mathrm{SO}_{4}$. The solvent was evaporated under the reduced pressure and the residue was purified by column chromatography on silica gel (eluent: petroleum ether: ethyl acetate $=2: 1$ to $1: 1$ ) to afford ethyl 4-((methylsulfonyl)oxy)piperidine-1-carboxylate (1c) in 98\% isolated yield (2.46 g) as a light yellow oil. ${ }^{1} \mathrm{H}$ NMR $\left(400 \mathrm{MHz}, \mathrm{CDCl}_{3}\right) \delta 4.93-4.87(\mathrm{~m}, 1 \mathrm{H}), 4.14(\mathrm{q}, J=7.2 \mathrm{~Hz}$, 2H), 3.77-3.71 (m, 2H), 3.42-3.35 (m, 2H), $3.05(\mathrm{~s}, 3 \mathrm{H}), 2.02-1.95(\mathrm{~m}, 2 \mathrm{H}), 1.87-1.79(\mathrm{~m}, 2 \mathrm{H})$, $1.27(\mathrm{t}, J=7.2 \mathrm{~Hz}, 3 \mathrm{H}) ;{ }^{13} \mathrm{C} \mathrm{NMR}\left(100 \mathrm{MHz}, \mathrm{CDCl}_{3}\right) \delta 155.1,77.2,61.3,40.2,38.6,31.4$, 14.5. IR (neat): 2935, 1689, 1433, 1348, 1273, 1229, 1170, 940, 909, 877, 855, 767 IR (neat): $1715,1448,1334,1299,1276,1163,1155,1021,932,816,714,651 \mathrm{~cm}^{-1}$. HRMS (ESI-TOF) $\mathrm{m} / \mathrm{z}:[\mathrm{M}+\mathrm{Na}]^{+}$calcd for $\mathrm{C}_{9} \mathrm{H}_{17} \mathrm{NO}_{5} \mathrm{NaS} 274.0720$; found 274.0724 .

\section{General procedure B for the synthesis of alkyl mesylates from ketones}

Typical procedure for the synthesis of $\mathbf{1 e}$. 


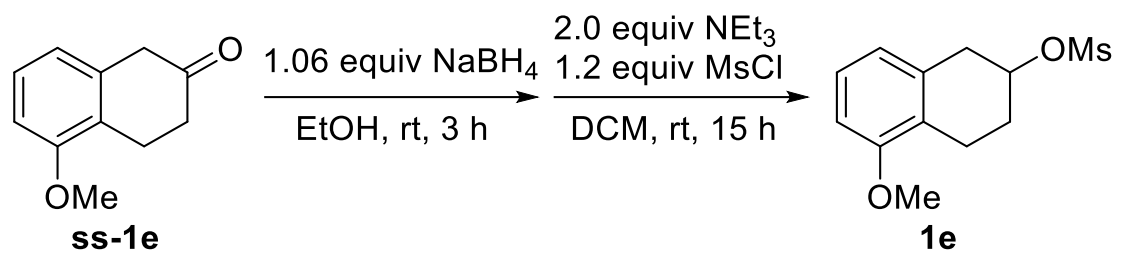

To a solution of ss-1e (1.23 g, $7 \mathrm{mmol})$ in $\mathrm{EtOH}(14 \mathrm{~mL})$ was added $\mathrm{NaBH}_{4}(279.9 \mathrm{mg}$, $7.4 \mathrm{mmol}$ ) by four portions in $15 \mathrm{~min}$ at room temperature under air. The mixture was stirred at room temperature for $3 \mathrm{~h}$. After the starting material was completely consumed, the mixture was quenched with saturated $\mathrm{NH}_{4} \mathrm{Cl}$ solution, extracted with $\mathrm{CH}_{2} \mathrm{Cl}_{2}$, dried over anhydrous $\mathrm{Na}_{2} \mathrm{SO}_{4}$. The solvent was evaporated under the reduced pressure and the residue was purified by column chromatography on silica gel (eluent: petroleum ether: ethyl acetate $=5: 1$ to $3: 1$ ) to afford the red oil which was used for the next step.

To a solution of the above product in $\mathrm{CH}_{2} \mathrm{Cl}_{2}(14 \mathrm{~mL})$ were added $\mathrm{NEt}_{3}(1.95 \mathrm{~mL}, 14 \mathrm{mmol})$ and $\mathrm{MsCl}(0.65 \mathrm{~mL}, 8.4 \mathrm{mmol})$ at room temperature under air. The mixture was stirred for 15 $\mathrm{h}$ at room temperature. After the starting material was completely consumed, the mixture was quenched with saturated $\mathrm{NH}_{4} \mathrm{Cl}$ solution, extracted with $\mathrm{CH}_{2} \mathrm{Cl}_{2}$, dried over anhydrous $\mathrm{Na}_{2} \mathrm{SO}_{4}$. The solvent was evaporated under the reduced pressure and the residue was purified by column chromatography on silica gel (eluent: petroleum ether: ethyl acetate $=5: 1$ ) to afford 5-methoxy1,2,3,4-tetrahydronaphthalen-2-yl methanesulfonate (1e) in 57\% isolated yield (1.02 g) over two steps as a light yellow solid. M.p. $79-81^{\circ} \mathrm{C} .{ }^{1} \mathrm{H} \mathrm{NMR}\left(400 \mathrm{MHz}, \mathrm{CDCl}_{3}\right) \delta 7.12(\mathrm{t}, J=7.6$ Hz, 1H), $6.68(\mathrm{~d}, J=8.0 \mathrm{~Hz}, 2 \mathrm{H}), 5.16-5.10(\mathrm{~m}, 1 \mathrm{H}), 3.81(\mathrm{~s}, 3 \mathrm{H}), 3.21-3.16(\mathrm{~m}, 1 \mathrm{H}), 3.11-$ $3.01(\mathrm{~m}, 4 \mathrm{H}), 2.94-2.86(\mathrm{~m}, 1 \mathrm{H}), 2.78-2.70(\mathrm{~m}, 1 \mathrm{H}), 2.15-2.07(\mathrm{~m}, 2 \mathrm{H}) ;{ }^{13} \mathrm{C} \mathrm{NMR}(100 \mathrm{MHz}$, $\left.\mathrm{CDCl}_{3}\right) \delta 156.9,133.5,126.7,123.7,121.2,107.5,77.6,55.2,38.7,35.4,28.3,20.3$. IR (neat): 2927, 1585, 1470, 1339, 1327, 1257, 1165, 1096, 1069, 980, 910, 881, 822, 771, 756 IR (neat): $1715,1448,1334,1299,1276,1163,1155,1021,932,816,714,651 \mathrm{~cm}^{-1}$. HRMS (ESI-TOF) $\mathrm{m} / \mathrm{z}:[\mathrm{M}+\mathrm{Na}]^{+}$calcd for $\mathrm{C}_{12} \mathrm{H}_{16} \mathrm{O}_{4} \mathrm{NaS} 279.0662$; found 279.0661 .<smiles>COC1Cc2ccccc2C1</smiles>

1d

2,3-Dihydro-1H-inden-2-yl methanesulfonate (1d). General procedure A, 5 mmol scale. The crude product was purified by column chromatography on silica gel (eluent: petroleum ether: 
ethyl acetate $=8: 1$ to $5: 1$ to dichloromethane) to afford $\mathbf{1 d}$ in $92 \%$ isolated yield $(977.2 \mathrm{mg})$ as a light yellow solid. ${ }^{1} \mathrm{H}$ NMR (400 MHz, $\left.\mathrm{CDCl}_{3}\right) \delta$ 7.26-7.19 (m, 4H), 5.53-5.48 (m, 1H), 3.35 $(\mathrm{dd}, J=17.2,6.4 \mathrm{~Hz}, 2 \mathrm{H}), 3.24(\mathrm{dd}, J=17.2,2.8 \mathrm{~Hz}, 2 \mathrm{H}), 3.00(\mathrm{~s}, 3 \mathrm{H}) ;{ }^{13} \mathrm{C}$ NMR $(100 \mathrm{MHz}$, $\left.\mathrm{CDCl}_{3}\right) \delta 139.0,127.1,124.6,81.8,40.1,38.5$. IR (neat): 3021, 1417, 1327, 1315, 1160, 1001, 944, 886, 797, 744, 731, $700 \mathrm{~cm}^{-1}$. HRMS (EI-TOF) m/z: [M] calcd for $\mathrm{C}_{10} \mathrm{H}_{12} \mathrm{O}_{3} \mathrm{~S} 212.0502$; found 212.0510.

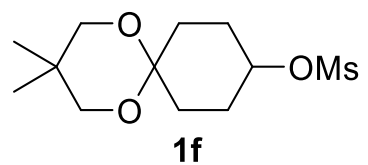

3,3-Dimethyl-1,5-dioxaspiro[5.5] undecan-9-yl methanesulfonate (1f). General procedure B, $10 \mathrm{mmol}$ scale. The crude product was purified by column chromatography on silica gel (eluent: petroleum ether: ethyl acetate $=5: 1)$ to afford $\mathbf{1 f}$ in $96 \%$ isolated yield ( $2.68 \mathrm{~g})$ over two steps as a white solid. ${ }^{1} \mathrm{H}$ NMR $\left(400 \mathrm{MHz}, \mathrm{CDCl}_{3}\right) \delta$ 4.85-4.80 (m, $\left.1 \mathrm{H}\right), 3.51(\mathrm{~s}, 2 \mathrm{H}), 3.48(\mathrm{~s}, 2 \mathrm{H})$, $3.02(\mathrm{~s}, 3 \mathrm{H}), 2.02-1.95(\mathrm{~m}, 2 \mathrm{H}), 1.93-1.89(\mathrm{~m}, 4 \mathrm{H}), 1.85-1.79(\mathrm{~m}, 2 \mathrm{H}), 0.97(\mathrm{~s}, 6 \mathrm{H}) ;{ }^{13} \mathrm{C} \mathrm{NMR}$ $\left(100 \mathrm{MHz}, \mathrm{CDCl}_{3}\right) \delta 96.2,79.0,70.2,69.9,38.6,30.1,28.1,22.6$. IR (neat): 2956, 1335, 1172 , 1098, 938, 913, 898, 858, $755 \mathrm{~cm}^{-1}$. HRMS (EI-TOF) m/z: [M] calcd for $\mathrm{C}_{12} \mathrm{H}_{22} \mathrm{O}_{5} \mathrm{~S} 278.1182$; found 278.1179 .

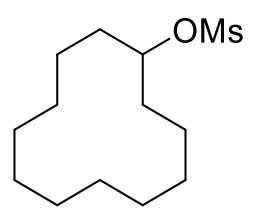

$1 \mathrm{~g}$

Cyclododecyl methanesulfonate (1g). General procedure A, 5 mmol scale. The crude product was purified by column chromatography on silica gel (eluent: petroleum ether: ethyl acetate $=$ 20:1 to $15: 1)$ to afford $1 \mathrm{~g}$ in $93 \%$ isolated yield (1.22 $\mathrm{g}$ ) as a white solid. ${ }^{1} \mathrm{H}$ NMR (400 MHz, $\left.\mathrm{CDCl}_{3}\right) \delta 4.90-4.84(\mathrm{~m}, 1 \mathrm{H}), 3.00(\mathrm{~s}, 3 \mathrm{H}), 1.90-1.83(\mathrm{~m}, 2 \mathrm{H}), 1.72-1.65(\mathrm{~m}, 2 \mathrm{H}), 1.51-1.34(\mathrm{~m}$, $18 \mathrm{H}) ;{ }^{13} \mathrm{C} \mathrm{NMR}\left(100 \mathrm{MHz}, \mathrm{CDCl}_{3}\right) \delta 81.9,38.6,30.0,23.9,23.8,23.1,23.0,20.5$. IR (neat): 2930, 1469, 1337, 1167, 975, 930, 908, 876, 868, 833, $723 \mathrm{~cm}^{-1}$. HRMS (EI-TOF) m/z: [M$\mathrm{Ms}]^{+}$calcd for $\mathrm{C}_{12} \mathrm{H}_{23} \mathrm{O}$ 183.1743; found 183.1746. 


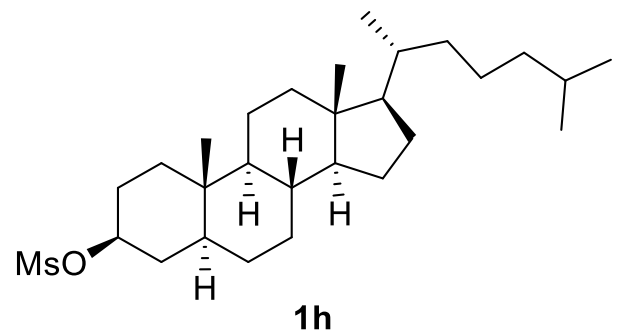

$(3 S, 5 S, 8 R, 9 S, 10 S, 13 R, 14 S, 17 R)-10,13-D i m e t h y l-17-((R)-6-m e t h y l h e p t a n-2-$

yl)hexadecahydro- $1 H$-cyclopenta $[a]$ phenanthren-3-yl methanesulfonate (1h). General procedure A, $3 \mathrm{mmol}$ scale. The crude product was purified by column chromatography on silica gel (eluent: petroleum ether: ethyl acetate $=10: 1)$ to afford $\mathbf{1 h}$ in $99 \%$ isolated yield $(1.38$ g) as a white solid. ${ }^{1} \mathrm{H}$ NMR $\left(400 \mathrm{MHz}, \mathrm{CDCl}_{3}\right) \delta 4.65-4.57(\mathrm{~m}, 1 \mathrm{H}), 2.99(\mathrm{~s}, 3 \mathrm{H}), 1.98-1.95$ $(\mathrm{m}, 2 \mathrm{H}), 1.84-0.94(\mathrm{~m}, 27 \mathrm{H}), 0.90-0.82(\mathrm{~m}, 13 \mathrm{H}), 0.65-0.60(\mathrm{~m}, 4 \mathrm{H}) ;{ }^{13} \mathrm{C}$ NMR $(100 \mathrm{MHz}$, $\left.\mathrm{CDCl}_{3}\right) \delta 82.2,56.3,56.2,54.0,44.8,42.5,39.9,39.4,38.8,36.7,36.1,35.7,35.3,35.2,35.1$, $31.8,28.6,28.4,28.2,27.9,24.1,23.8,22.8,22.5,21.2,18.6,12.1,12.0$. The spectroscopic data is in agreement with that previously reported. ${ }^{4}$<smiles>COc1ccc(CCC(C)OC)cc1</smiles>

4-(4-Methoxyphenyl)butan-2-yl methanesulfonate (1i). General procedure B, 10 mmol scale. The crude product was purified by column chromatography on silica gel (eluent: petroleum ether: ethyl acetate $=5: 1)$ to afford $1 \mathbf{i}$ in $96 \%$ isolated yield $(2.48 \mathrm{~g})$ over two steps as a light yellow oil. ${ }^{1} \mathrm{H}$ NMR $\left(400 \mathrm{MHz}, \mathrm{CDCl}_{3}\right) \delta 7.11(\mathrm{~d}, J=8.4 \mathrm{~Hz}, 2 \mathrm{H}), 6.85-6.82(\mathrm{~m}, 2 \mathrm{H}), 4.86-$ $4.78(\mathrm{~m}, 1 \mathrm{H}), 3.78(\mathrm{~s}, 3 \mathrm{H}), 2.99(\mathrm{~s}, 3 \mathrm{H}), 2.74-2.60(\mathrm{~m}, 2 \mathrm{H}), 2.07-1.98(\mathrm{~m}, 1 \mathrm{H}), 1.93-1.84(\mathrm{~m}$, $1 \mathrm{H}), 1.45(\mathrm{~d}, J=6.4 \mathrm{~Hz}, 3 \mathrm{H}) ;{ }^{13} \mathrm{C} \mathrm{NMR}\left(100 \mathrm{MHz}, \mathrm{CDCl}_{3}\right) \delta 157.9,132.6,129.2,113.9,79.5$, 55.2, 38.6, 38.5, 30.4, 21.2. IR (neat): 2937, 1608, 1511, 1335, 1240, 1169, 972, 916, 899, 831, $817,805,749 \mathrm{~cm}^{-1}$. HRMS (ESI-TOF) m/z: $[\mathrm{M}+\mathrm{Na}]^{+}$calcd for $\mathrm{C}_{12} \mathrm{H}_{18} \mathrm{O}_{4} \mathrm{NaS} 281.0818$; found 281.0826 . 
<smiles>CCCC(CCc1ccccc1)OC</smiles>

1-Phenylhexan-3-yl methanesulfonate (1j). General procedure B, $10 \mathrm{mmol}$ scale. The crude product was purified by column chromatography on silica gel (eluent: petroleum ether: ethyl acetate $=10: 1)$ to afford $\mathbf{1} \mathbf{j}$ in $77 \%$ isolated yield $(1.97 \mathrm{~g})$ over two steps as a yellow oil. ${ }^{1} \mathrm{H}$ NMR (400 MHz, $\left.\mathrm{CDCl}_{3}\right) \delta 7.27(\mathrm{t}, J=8.0 \mathrm{~Hz}, 2 \mathrm{H}), 7.19$ (d, $\left.J=7.6 \mathrm{~Hz}, 3 \mathrm{H}\right), 4.78-4.72(\mathrm{~m}$, $1 \mathrm{H}), 2.95(\mathrm{~s}, 3 \mathrm{H}), 2.78-2.64(\mathrm{~m}, 2 \mathrm{H}), 2.07-1.93(\mathrm{~m}, 2 \mathrm{H}), 1.79-1.63(\mathrm{~m}, 2 \mathrm{H}), 1.51-1.33(\mathrm{~m}, 2 \mathrm{H})$, $0.93(\mathrm{t}, J=7.2 \mathrm{~Hz}, 3 \mathrm{H}) ;{ }^{13} \mathrm{C} \mathrm{NMR}\left(100 \mathrm{MHz}, \mathrm{CDCl}_{3}\right) \delta 140.8,128.3,128.1,125.9,82.9,38.4$, 36.3, 35.9, 31.0, 18.0, 13.6. IR (neat): 2961, 1456, 1330, 1170, 969, 896, 751, $699 \mathrm{~cm}^{-1}$. HRMS (EI-TOF) m/z: [M-OMs-H] $]^{+}$calcd for $\mathrm{C}_{12} \mathrm{H}_{16}$ 160.1247; found 160.1240 .<smiles>COC(Cc1ccccc1)Cc1ccccc1</smiles>

1,3-Diphenylpropan-2-yl methanesulfonate (1k). General procedure B, 10 mmol scale. The crude product was purified by column chromatography on silica gel (eluent: petroleum ether: ethyl acetate $=10: 1$ to $5: 1)$ to afford $1 \mathbf{k}$ in $83 \%$ isolated yield $(2.42 \mathrm{~g})$ over two steps as a light yellow oil. M.p. 79-81 ${ }^{\circ} \mathrm{C} .{ }^{1} \mathrm{H}$ NMR (400 MHz, $\left.\mathrm{CDCl}_{3}\right) \delta$ 7.34-7.21 (m, 10H), 4.93-4.86 (m, $1 \mathrm{H}), 3.00(\mathrm{~d}, J=6.4 \mathrm{~Hz}, 4 \mathrm{H}), 2.15(\mathrm{~s}, 3 \mathrm{H}) ;{ }^{13} \mathrm{C} \mathrm{NMR}\left(100 \mathrm{MHz}, \mathrm{CDCl}_{3}\right) \delta 136.5,129.6,128.6$, 127.0, 85.9, 41.0, 37.0. IR (neat): 3029, 1453, 1342, 1170, 971, 896, 881, 755, 744, $700 \mathrm{~cm}^{-1}$. HRMS (ESI-TOF) m/z: [M+Na] $]^{+}$calcd for $\mathrm{C}_{16} \mathrm{H}_{18} \mathrm{O}_{3} \mathrm{NaS}$ 313.0869; found 313.0861.<smiles>COC(C)Cc1cccc(C(F)(F)F)c1</smiles>

1-(3-(Trifluoromethyl)phenyl)propan-2-yl methanesulfonate (11). General procedure B, 10 mmol scale. The crude product was purified by column chromatography on silica gel (eluent: petroleum ether: ethyl acetate: dichloromethane $=5: 1: 1)$ to afford 11 in $85 \%$ isolated yield $(2.41$ g) over two steps as a yellow oil. ${ }^{1} \mathrm{H}$ NMR $\left(400 \mathrm{MHz}, \mathrm{CDCl}_{3}\right) \delta 7.53-7.52(\mathrm{~m}, 2 \mathrm{H}), 7.46-7.43$ $(\mathrm{m}, 2 \mathrm{H}), 4.97-4.89(\mathrm{~m}, 1 \mathrm{H}), 3.07-2.97(\mathrm{~m}, 2 \mathrm{H}), 2.62(\mathrm{~s}, 3 \mathrm{H}), 1.46(\mathrm{~d}, J=6.4 \mathrm{~Hz}, 3 \mathrm{H}) ;{ }^{13} \mathrm{C}$ 
$\operatorname{NMR}\left(100 \mathrm{MHz}, \mathrm{CDCl}_{3}\right) \delta 137.6,133.0\left(\mathrm{~d},{ }^{4} J_{\mathrm{C}-\mathrm{F}}=1.5 \mathrm{~Hz}\right), 130.4\left(\mathrm{q},{ }^{2} J_{\mathrm{C}-\mathrm{F}}=32.0 \mathrm{~Hz}\right), 128.9$, $126.0\left(\mathrm{q},{ }^{3} J_{\mathrm{C}-\mathrm{F}}=3.7 \mathrm{~Hz}\right), 123.9\left(\mathrm{q},{ }^{1} J_{\mathrm{C}-\mathrm{F}}=270.7 \mathrm{~Hz}\right), 123.6\left(\mathrm{q},{ }^{3} J_{\mathrm{C}-\mathrm{F}}=3.7 \mathrm{~Hz}\right), 80.1,42.2,37.5$, 20.8. IR (neat): 1363, 1346, 1328, 1168, 1127, 1073, 906, 889, 811, $704 \mathrm{~cm}^{-1}$. HRMS (EI-TOF) $\mathrm{m} / \mathrm{z}$ : $\left[\mathrm{M}-\mathrm{CH}_{3}\right]^{+}$calcd for $\mathrm{C}_{10} \mathrm{H}_{10} \mathrm{O}_{3} \mathrm{~F}_{3} \mathrm{~S}$ 267.0297; found 267.0309 .<smiles>COC(C)Cc1ccc(Br)cc1</smiles>

1-(4-Bromophenyl)propan-2-yl methanesulfonate $(\mathbf{1 m})$. General procedure B, $10 \mathrm{mmol}$ scale. The crude product was purified by column chromatography on silica gel (eluent: petroleum ether: ethyl acetate: dichloromethane $=4: 1: 1)$ to afford $1 \mathbf{m}$ in $89 \%$ isolated yield (2.60 g) over two steps as a yellow oil. ${ }^{1} \mathrm{H} \mathrm{NMR}\left(400 \mathrm{MHz}, \mathrm{CDCl}_{3}\right) \delta 7.43(\mathrm{~d}, J=8.4 \mathrm{~Hz}, 2 \mathrm{H})$, $7.11(\mathrm{~d}, J=8.0 \mathrm{~Hz}, 2 \mathrm{H}), 4.91-4.83(\mathrm{~m}, 1 \mathrm{H}), 2.96-2.85(\mathrm{~m}, 2 \mathrm{H}), 2.64(\mathrm{~s}, 3 \mathrm{H}), 1.43(\mathrm{~d}, J=6.4$ $\mathrm{Hz}, 3 \mathrm{H}) ;{ }^{13} \mathrm{C}$ NMR $\left(100 \mathrm{MHz}, \mathrm{CDCl}_{3}\right) \delta 135.4,131.4,131.1,120.7,80.2,42.0,37.7,20.9$. IR (neat): $1487,1370,1343,1330,1171,918,906,892,841,801,786,710 \mathrm{~cm}^{-1}$. HRMS (EI-TOF) $\mathrm{m} / \mathrm{z}:[\mathrm{M}]^{+}$calcd for $\mathrm{C}_{10} \mathrm{H}_{13} \mathrm{O}_{3} \mathrm{BrS} 291.9763$; found 291.9766 .

\section{Synthesis of $1 \mathrm{n}$}

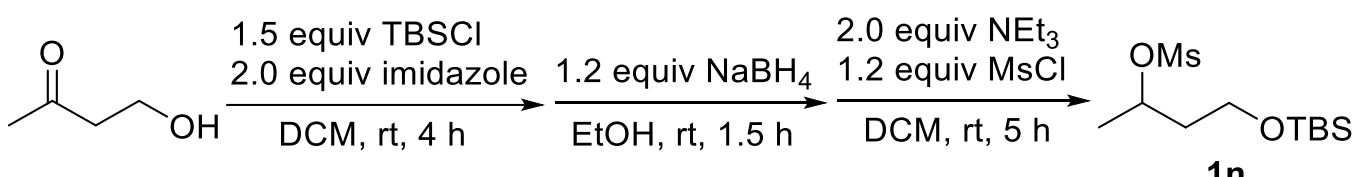

To a solution of 4-hydroxy-2-butanone $(881.1 \mathrm{mg}, 10 \mathrm{mmol})$ in $\mathrm{CH}_{2} \mathrm{Cl}_{2}(20 \mathrm{~mL})$ were added imidazole (1.36 g, $20 \mathrm{mmol})$ and $\mathrm{TBSCl}(2.26 \mathrm{~g}, 15 \mathrm{mmol})$ at room temperature under air. The mixture was stirred for $4 \mathrm{~h}$ at room temperature. After the starting material was completely consumed, the mixture was quenched with saturated $\mathrm{NaHCO}_{3}$ solution, extracted with $\mathrm{CH}_{2} \mathrm{Cl}_{2}$, dried over anhydrous $\mathrm{Na}_{2} \mathrm{SO}_{4}$. The solvent was evaporated under the reduced pressure and the residue was purified by column chromatography on silica gel (eluent: petroleum ether: ethyl acetate $=10: 1)$ to afford the yellow oil which was used for the next step.

To a solution of the product above in EtOH $(20 \mathrm{~mL})$ was added $\mathrm{NaBH}_{4}(454.0 \mathrm{mg}, 12$ $\mathrm{mmol}$ ) by four portions in $15 \mathrm{~min}$ at room temperature under air. The mixture was stirred at 
room temperature for $1.5 \mathrm{~h}$. After the starting material was completely consumed, the mixture was quenched with saturated $\mathrm{NaHCO}_{3}$ solution, extracted with ethyl acetate, dried over anhydrous $\mathrm{Na}_{2} \mathrm{SO}_{4}$. The solvent was evaporated under the reduced pressure and the residue was purified by column chromatography on silica gel (eluent: petroleum ether: ethyl acetate $=$ 10:1 to $5: 1)$ to afford the colourless oil which was used for the next step.

To a solution of the product above in $\mathrm{CH}_{2} \mathrm{Cl}_{2}(20 \mathrm{~mL})$ were added $\mathrm{NEt}_{3}(2.78 \mathrm{~mL}, 20 \mathrm{mmol})$ and $\mathrm{MsCl}(0.93 \mathrm{~mL}, 12 \mathrm{mmol})$ at room temperature under air. The mixture was stirred for $5 \mathrm{~h}$ at room temperature. After the starting material was completely consumed, the mixture was quenched with saturated $\mathrm{NaHCO}_{3}$ solution, extracted with $\mathrm{CH}_{2} \mathrm{Cl}_{2}$, dried over anhydrous $\mathrm{Na}_{2} \mathrm{SO}_{4}$. The solvent was evaporated under the reduced pressure and the residue was purified by column chromatography on silica gel (eluent: petroleum ether: ethyl acetate $=10: 1$ to $5: 1$ ) to afford 4-((tert-butyldimethylsilyl)oxy)butan-2-yl methanesulfonate (1n) in 68\% isolated yield (1.93 g) over three steps as a light yellow oil. ${ }^{1} \mathrm{H}$ NMR (400 $\left.\mathrm{MHz}, \mathrm{CDCl}_{3}\right) \delta 5.00-4.92$ (m, 1H), 3.75-3.67 (m, 2H), $3.02(\mathrm{~s}, 3 \mathrm{H}), 1.94-1.86(\mathrm{~m}, 1 \mathrm{H}), 1.82-1.70(\mathrm{~m}, 1 \mathrm{H}), 1.47(\mathrm{~d}, J=$ $6.4 \mathrm{~Hz}, 3 \mathrm{H}), 0.89$ (s, 9H), 0.06 (s, 6H); ${ }^{13} \mathrm{C} \mathrm{NMR}\left(100 \mathrm{MHz}, \mathrm{CDCl}_{3}\right) \delta$ 77.5, 58.4, 39.4, 38.0, 25. 8, 21.6, 18.1, -5.5. IR (neat): 2930, 1352, 1255, 1175, 1086, 900, 834, 811, $775 \mathrm{~cm}^{-1}$. HRMS (ESI-TOF) m/z: [M+Na] $]^{+}$calcd for $\mathrm{C}_{11} \mathrm{H}_{26} \mathrm{O}_{4} \mathrm{NaSiS}$ 305.1213; found 305.1218.

\section{Synthesis of 10}

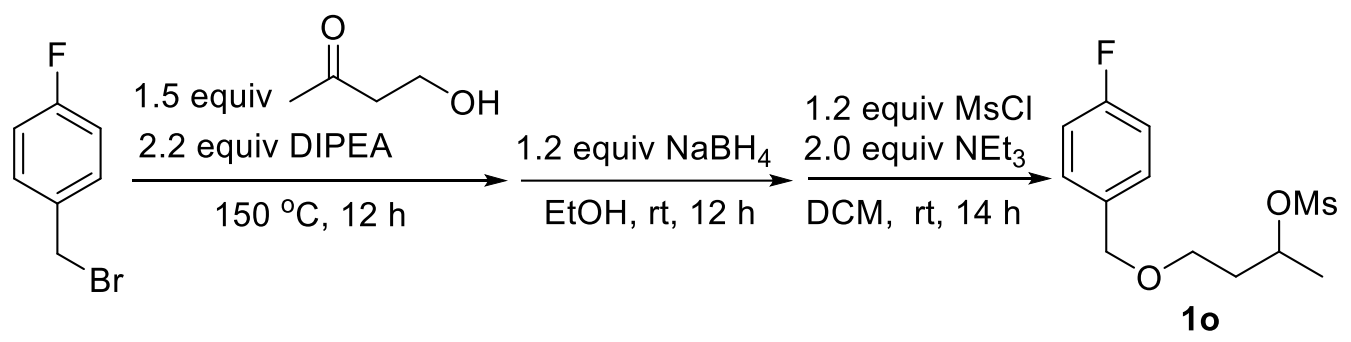

4-Fluorobenzyl bromide (1.89 g, $10 \mathrm{mmol})$, 4-hydroxy-2-butanone (1.32 g, $15 \mathrm{mmol})$ and DIPEA (3.64 mL, $22 \mathrm{mmol}$ ) were charged in a reaction vessel under Ar. The mixture was heated at $150{ }^{\circ} \mathrm{C}$ (oil bath) for $12 \mathrm{~h}$. After the starting material was completely consumed, the mixture was quenched with $1 \mathrm{M} \mathrm{HCl}$, extracted with ethyl acetate, dried over anhydrous $\mathrm{Na}_{2} \mathrm{SO}_{4}$. The solvent was evaporated under the reduced pressure and the residue was purified by column chromatography on silica gel (eluent: petroleum ether: ethyl acetate $=10: 1$ to $8: 1$ ) to afford the 
yellow oil which was used for the next step.

To a solution of the above product in $\mathrm{EtOH}(20 \mathrm{~mL})$ was added $\mathrm{NaBH}_{4}(454.0 \mathrm{mg}, 12$ mmol) by four portions in $15 \mathrm{~min}$ at room temperature under air. The mixture was stirred at room temperature for $12 \mathrm{~h}$. After the starting material was completely consumed, the mixture was quenched with saturated $\mathrm{NH}_{4} \mathrm{Cl}$ solution, extracted with ethyl acetate, dried over anhydrous $\mathrm{Na}_{2} \mathrm{SO}_{4}$. The solvent was evaporated under the reduced pressure and the residue was purified by column chromatography on silica gel (eluent: petroleum ether: ethyl acetate $=$ 5:1 to 2:1) to afford the colourless oil which was used for the next step.

To a solution of the above product in $\mathrm{CH}_{2} \mathrm{Cl}_{2}(20 \mathrm{~mL})$ were added $\mathrm{NEt}_{3}(2.78 \mathrm{~mL}, 20 \mathrm{mmol})$ and $\mathrm{MsCl}(0.93 \mathrm{~mL}, 12 \mathrm{mmol})$ separately at room temperature under air. The mixture was stirred for $14 \mathrm{~h}$ at room temperature. After the starting material was completely consumed, the mixture was quenched with saturated $\mathrm{NH}_{4} \mathrm{Cl}$ solution, extracted with $\mathrm{CH}_{2} \mathrm{Cl}_{2}$, dried over anhydrous $\mathrm{Na}_{2} \mathrm{SO}_{4}$. The solvent was evaporated under the reduced pressure and the residue was purified by column chromatography on silica gel (eluent: petroleum ether: ethyl acetate $=$ 5:1 to 3:1) to afford 4-((4-fluorobenzyl)oxy)butan-2-yl methanesulfonate (10) in 52\% isolated yield $(1.44 \mathrm{~g})$ over three steps as a yellow oil. ${ }^{1} \mathrm{H}$ NMR $\left(400 \mathrm{MHz}, \mathrm{CDCl}_{3}\right) \delta$ 7.32-7.29 (m, 2H), 7.03 (t, $J=8.4 \mathrm{~Hz}, 2 \mathrm{H}), 5.03-4.95(\mathrm{~m}, 1 \mathrm{H}), 4.46$ (dd, $J=16.0 \mathrm{~Hz}, 11.6 \mathrm{~Hz}, 2 \mathrm{H}), 3.62-$ $3.52(\mathrm{~m}, 2 \mathrm{H}), 2.96(\mathrm{~s}, 3 \mathrm{H}), 2.01-1.86(\mathrm{~m}, 2 \mathrm{H}), 1.45(\mathrm{~d}, J=6.4 \mathrm{~Hz}, 3 \mathrm{H}) ;{ }^{13} \mathrm{C} \mathrm{NMR}(100 \mathrm{MHz}$, $\left.\mathrm{CDCl}_{3}\right) \delta 162.3\left(\mathrm{~d},{ }^{1} J_{\mathrm{C}-\mathrm{F}}=244.0 \mathrm{~Hz}\right), 133.7\left(\mathrm{~d},{ }^{4} J_{\mathrm{C}-\mathrm{F}}=2.9 \mathrm{~Hz}\right), 129.5\left(\mathrm{~d},{ }^{3} J_{\mathrm{C}-\mathrm{F}}=8.2 \mathrm{~Hz}\right), 115.2$ $\left(\mathrm{d},{ }^{2} J_{\mathrm{C}-\mathrm{F}}=21.1 \mathrm{~Hz}\right), 77.3,72.4,65.7,38.2,36.6,21.5$. IR (neat): 2875, 1605, 1503, 1333, 1211, 1171, 1090, 900, 855, 815, 783, $720 \mathrm{~cm}^{-1}$. HRMS (ESI-TOF) m/z: $[\mathrm{M}+\mathrm{Na}]^{+}$calcd for $\mathrm{C}_{12} \mathrm{H}_{17} \mathrm{O}_{4} \mathrm{FNaS} 299.0724$; found 299.0724.

\section{Synthesis of 1p}

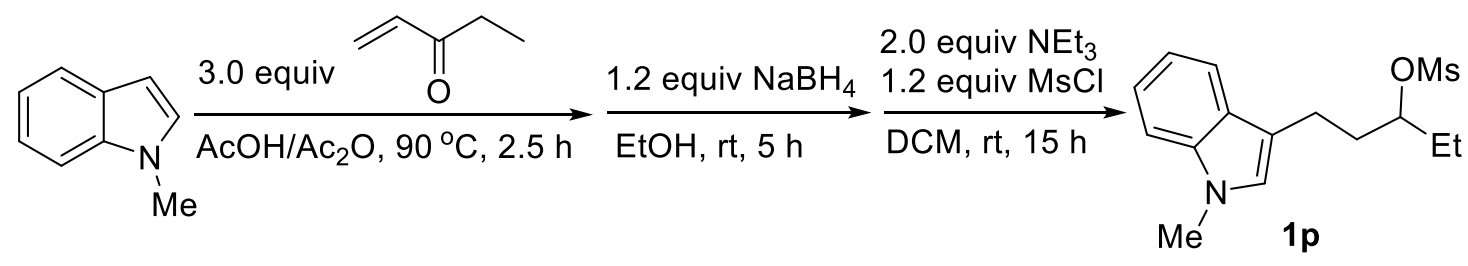

To a solution of 1-methylindole $(1.31 \mathrm{~g}, 10 \mathrm{mmol})$ in $\mathrm{AcOH}(6 \mathrm{~mL})$ and $\mathrm{Ac}_{2} \mathrm{O}(2 \mathrm{~mL})$ was added ethyl vinyl ketone $(2.97 \mathrm{~mL}, 30 \mathrm{mmol})$ at room temperature under air. After stirring for 
$5 \mathrm{~min}$ at room temperature, the mixture was heated to $90{ }^{\circ} \mathrm{C}$ (oil bath) and stirred for $2.5 \mathrm{~h}$. After the starting material was completely consumed, the mixture was cooled to $0{ }^{\circ} \mathrm{C}$, quenched with water, added $\mathrm{NaHCO}_{3}$ until the mixture was base, extracted with ethyl acetate, dried over anhydrous $\mathrm{Na}_{2} \mathrm{SO}_{4}$. The solvent was evaporated under the reduced pressure and the residue was purified by column chromatography on silica gel (eluent: petroleum ether: ethyl acetate = 10:1) to afford the yellow oil which was used for the next step.

To a solution of the above product in $\mathrm{EtOH}(20 \mathrm{~mL})$ was added $\mathrm{NaBH}_{4}(454.0 \mathrm{mg}, 12$ mmol) by four portions in $15 \mathrm{~min}$ at room temperature under air. The mixture was stirred at room temperature for $5 \mathrm{~h}$. After the starting material was completely consumed, the mixture was quenched with saturated $\mathrm{NH}_{4} \mathrm{Cl}$ solution, extracted with ethyl acetate, dried over anhydrous $\mathrm{Na}_{2} \mathrm{SO}_{4}$. The solvent was evaporated under the reduced pressure and the residue was purified by column chromatography on silica gel (eluent: petroleum ether: ethyl acetate $=$ $5: 1$ to $2: 1$ ) to afford the yellow oil which was used for the next step.

To a solution of the above product in $\mathrm{CH}_{2} \mathrm{Cl}_{2}(20 \mathrm{~mL})$ were added $\mathrm{NEt}_{3}(2.78 \mathrm{~mL}, 20 \mathrm{mmol})$ and $\mathrm{MsCl}(0.93 \mathrm{~mL}, 12 \mathrm{mmol})$ separately at room temperature under air. The mixture was stirred for $15 \mathrm{~h}$ at room temperature. After the starting material was completely consumed, the mixture was quenched with saturated $\mathrm{NH}_{4} \mathrm{Cl}$ solution, extracted with $\mathrm{CH}_{2} \mathrm{Cl}_{2}$, dried over anhydrous $\mathrm{Na}_{2} \mathrm{SO}_{4}$. The solvent was evaporated under the reduced pressure and the residue was purified by column chromatography on silica gel (eluent: petroleum ether: dichloromethane $=1: 1$ to $1: 3)$ to afford 1-(1-methyl-1H-indol-3-yl)pentan-3-yl methanesulfonate (1p) in $62 \%$ isolated yield (1.83 g) over three steps as a yellow oil. ${ }^{1} \mathrm{H}$ NMR $\left(400 \mathrm{MHz}, \mathrm{CDCl}_{3}\right) \delta 7.55(\mathrm{~d}, J=8.0 \mathrm{~Hz}, 1 \mathrm{H}), 7.27(\mathrm{~d}, J=8.0 \mathrm{~Hz}, 1 \mathrm{H}), 7.22-7.19(\mathrm{~m}, 1 \mathrm{H})$, 7.11-7.07 (m, 1H), $6.88(\mathrm{~s}, 1 \mathrm{H}), 4.79-4.73(\mathrm{~m}, 1 \mathrm{H}), 3.70(\mathrm{~s}, 3 \mathrm{H}), 2.96(\mathrm{~s}, 3 \mathrm{H}), 2.92-2.78(\mathrm{~m}$, 2H), 2.15-1.99 (m, 2H), 1.86-1.71 (m, 2H), $0.98(\mathrm{t}, J=7.6 \mathrm{~Hz}, 3 \mathrm{H}) ;{ }^{13} \mathrm{C}$ NMR $(100 \mathrm{MHz}$, $\left.\mathrm{CDCl}_{3}\right) \delta 136.9,127.4,126.3,121.4,118.6,118.5,113.2,109.1,84.5,38.5,34.3,32.4,27.3$, 20.5, 9.0. IR (neat): 2927, 1480, 1342, 1326, 1172, 974, 901, 840, $737 \mathrm{~cm}^{-1}$. HRMS (ESI-TOF) $\mathrm{m} / \mathrm{z}:[\mathrm{M}+\mathrm{Na}]^{+}$calcd for $\mathrm{C}_{15} \mathrm{H}_{21} \mathrm{NO}_{3} \mathrm{NaS} 318.1134$; found 318.1136 . 


\section{Synthesis of 1q}
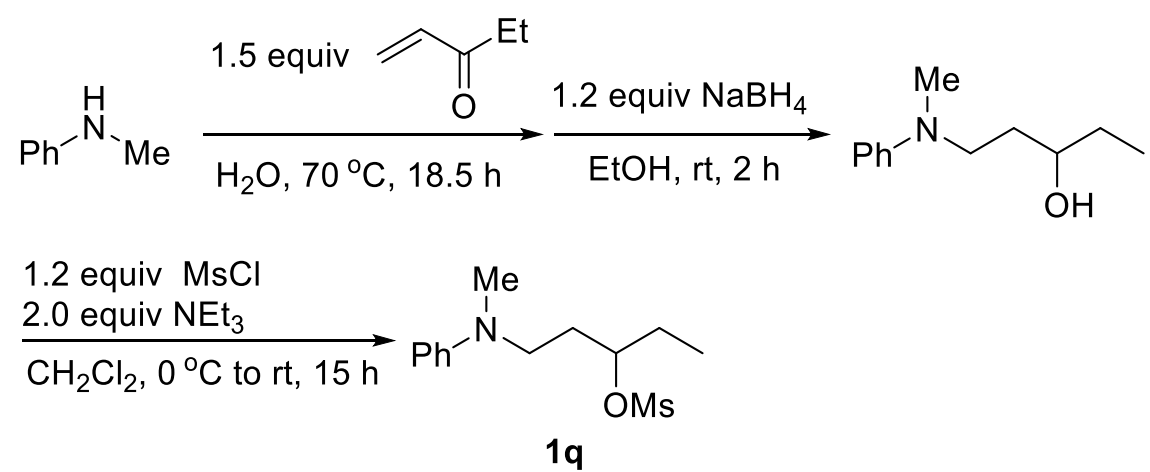

To a solution of $\mathrm{N}$-Methylaniline $(0.54 \mathrm{~mL}, 5 \mathrm{mmol})$ in $\mathrm{H}_{2} \mathrm{O}(5 \mathrm{~mL})$ was added ethyl vinyl ketone $(630.9 \mathrm{mg}, 7.5 \mathrm{mmol})$ at room temperature under air. The mixture was stirred for 18.5 $\mathrm{h}$ at $70{ }^{\circ} \mathrm{C}$ (oil bath). After the starting material was completely consumed, the mixture was extracted with ethyl acetate, dried over anhydrous $\mathrm{Na}_{2} \mathrm{SO}_{4}$. The solvent was evaporated under the reduced pressure and the residue was purified by column chromatography on silica gel (eluent: petroleum ether: ethyl acetate $=15: 1$ to $10: 1)$ to afford the light yellow oil which was used for the next step.

To a solution of the above product in $\operatorname{EtOH}(10 \mathrm{~mL})$ was added $\mathrm{NaBH}_{4}(226.9 \mathrm{mg}, 6 \mathrm{mmol})$ at room temperature under air. The mixture was stirred at room temperature for $2 \mathrm{~h}$. After the starting material was completely consumed, the mixture was quenched with saturated $\mathrm{NH}_{4} \mathrm{Cl}$ solution, extracted with ethyl acetate, washed with brine, dried over anhydrous $\mathrm{Na}_{2} \mathrm{SO}_{4}$. The solvent was evaporated under the reduced pressure and the residue was purified by column chromatography on silica gel (eluent: petroleum ether: ethyl acetate $=15: 1$ to $5: 1$ ) to afford the light yellow oil which was used for the next step.

To a solution of the above product $(386.6 \mathrm{mg}, 2 \mathrm{mmol})$ in $\mathrm{CH}_{2} \mathrm{Cl}_{2}(10 \mathrm{~mL})$ were added $\mathrm{NEt}_{3}(0.56 \mathrm{~mL}, 4 \mathrm{mmol})$ at room temperature under air. The mixture was placed at $0{ }^{\circ} \mathrm{C}$ and $\mathrm{MsCl}(0.19 \mathrm{~mL}, 2.4 \mathrm{mmol})$ was then added to the mixture. The mixture was stirred for $15 \mathrm{~h}$ at room temperature. After the starting material was completely consumed, the mixture was quenched with saturated $\mathrm{NH}_{4} \mathrm{Cl}$ solution, extracted with $\mathrm{CH}_{2} \mathrm{Cl}_{2}$, washed with brine, dried over anhydrous $\mathrm{Na}_{2} \mathrm{SO}_{4}$. The solvent was evaporated under the reduced pressure and the residue was purified by column chromatography on silica gel (eluent: petroleum ether: ethyl acetate $=$ 10:1 to $5: 1$ ) to 1-(methyl(phenyl)amino)pentan-3-yl methanesulfonate (1q) in $70 \%$ isolated yield $(379.5 \mathrm{mg})$ as a yellow oil. ${ }^{1} \mathrm{H}$ NMR $\left(400 \mathrm{MHz}, \mathrm{CDCl}_{3}\right) \delta$ 7.24-7.20 (m, 2H), 6.71-6.68 
(m, 3H), 4.75-4.69 (m, 1H), 3.53-3.36 (m, 2H), 2.97 (s, 3H), $2.92(\mathrm{~s}, 3 \mathrm{H}), 1.95-1.90(\mathrm{~m}, 2 \mathrm{H})$, $1.80-1.73(\mathrm{~m}, 2 \mathrm{H}), 0.97(\mathrm{t}, J=7.6 \mathrm{~Hz}, 3 \mathrm{H}) ;{ }^{13} \mathrm{C} \mathrm{NMR}\left(100 \mathrm{MHz}, \mathrm{CDCl}_{3}\right) \delta 148.8,129.1,116.5$, 112.4, 82.9, 48.5, 38.5, 38.3, 30.3, 27.6, 9.1. IR (neat): 2936, 1599, 1506, 1331, 1171, 903, 748, $692 \mathrm{~cm}^{-1}$. HRMS (ESI-TOF) m/z: [M+H] $]^{+}$calcd for $\mathrm{C}_{13} \mathrm{H}_{22} \mathrm{NO}_{3} \mathrm{~S} 272.1315$; found 272.1317.<smiles>COCCCCc1ccc(OC)cc1</smiles>

4-(4-Methoxyphenyl)butyl methanesulfonate (8a). General procedure A, 15 mmol scale. The crude product was purified by column chromatography on silica gel (eluent: petroleum ether: ethyl acetate $=10: 1$ to $5: 1)$ to afford $8 \mathbf{a}$ in $98 \%$ isolated yield (3.78 $\mathrm{g})$ as a colourless oil. ${ }^{1} \mathrm{H} \mathrm{NMR}\left(400 \mathrm{MHz}, \mathrm{CDCl}_{3}\right) \delta 7.08(\mathrm{~d}, J=8.4 \mathrm{~Hz}, 2 \mathrm{H}), 6.82(\mathrm{~d}, J=8.8 \mathrm{~Hz}, 2 \mathrm{H}), 4.21$ (t, $J=$ $6.0 \mathrm{~Hz}, 2 \mathrm{H}), 3.77$ (s, 3H), 2.97 (s, 3H), 2.59 (t, $J=7.2 \mathrm{~Hz}, 2 \mathrm{H}), 1.79-1.66(\mathrm{~m}, 4 \mathrm{H}) ;{ }^{13} \mathrm{C} \mathrm{NMR}$ $\left(100 \mathrm{MHz} \mathrm{CDCl}_{3}\right) \delta 157.74,133.5,129.2,113.7,69.9,55.1,37.1,34.1,28.4,27.3$. The spectroscopic data is in agreement with that previously reported. ${ }^{5}$<smiles>COCC(C)Cc1ccc2c(c1)OCO2</smiles>

3-(Benzo $[d][1,3]$ dioxol-5-yl)-2-methylpropyl methanesulfonate $(\mathbf{8 b})$. General procedure B, $10 \mathrm{mmol}$ scale. The crude product was purified by column chromatography on silica gel (eluent: petroleum ether: ethyl acetate: dichloromethane $=4: 1: 1$ ) to afford $\mathbf{8 b}$ in $88 \%$ isolated yield (2.39 g) over two steps as a yellow oil. ${ }^{1} \mathrm{H}$ NMR (400 MHz, $\left.\mathrm{CDCl}_{3}\right) \delta 6.73(\mathrm{~d}, J=7.6 \mathrm{~Hz}, 1 \mathrm{H})$, $6.65(\mathrm{~s}, 1 \mathrm{H}), 6.60(\mathrm{~d}, J=7.6 \mathrm{~Hz}, 1 \mathrm{H}), 5.92(\mathrm{~s}, 2 \mathrm{H}), 4.09-4.00(\mathrm{~m}, 2 \mathrm{H}), 3.00(\mathrm{~s}, 3 \mathrm{H}), 2.69-2.64$ $(\mathrm{m}, 1 \mathrm{H}), 2.46-2.41(\mathrm{~m}, 1 \mathrm{H}), 2.17-2.09(\mathrm{~m}, 1 \mathrm{H}), 0.98(\mathrm{~d}, J=6.8 \mathrm{~Hz}, 3 \mathrm{H}) ;{ }^{13} \mathrm{C} \mathrm{NMR}(100 \mathrm{MHz}$, $\left.\mathrm{CDCl}_{3}\right) \delta 147.2,145.6,132.5,121.6,108.9,107.7,100.5,73.4,38.2,36.5,34.6,15.7$. IR (neat): 2919, 1495, 1440, 1333, 1241, 1163, 1035, 963, 930, 851, 799, $749 \mathrm{~cm}^{-1}$. HRMS (ESI-TOF) $\mathrm{m} / \mathrm{z}:[\mathrm{M}+\mathrm{Na}]^{+}$calcd for $\mathrm{C}_{12} \mathrm{H}_{16} \mathrm{O}_{5} \mathrm{NaS} 295.0611$; found 295.0610 . 


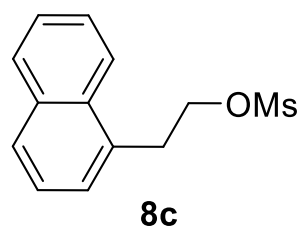

2-(Naphthalen-1-yl)ethyl methanesulfonate (8c). General procedure A, 5 mmol scale. The crude product was purified by column chromatography on silica gel (eluent: petroleum ether: ethyl acetate $=5: 1$ to $3: 1)$ to afford $\mathbf{8 c}$ in $99 \%$ isolated yield $(1.24 \mathrm{~g})$ as a colourless oil. ${ }^{1} \mathrm{H}$ NMR $\left(400 \mathrm{MHz}, \mathrm{CDCl}_{3}\right) \delta 7.95(\mathrm{~d}, J=8.4 \mathrm{~Hz}, 1 \mathrm{H}), 7.81(\mathrm{~d}, J=7.6 \mathrm{~Hz}, 1 \mathrm{H}), 7.72(\mathrm{~d}, J=8.0$ $\mathrm{Hz}, 1 \mathrm{H}), 7.52-7.43(\mathrm{~m}, 2 \mathrm{H}), 7.38-7.31(\mathrm{~m}, 2 \mathrm{H}), 4.45$ (t, $J=7.2 \mathrm{~Hz}, 2 \mathrm{H}), 3.45$ (t, $J=7.2 \mathrm{~Hz}$, 2H), $2.69(\mathrm{~s}, 3 \mathrm{H}) ;{ }^{13} \mathrm{C}$ NMR $\left(100 \mathrm{MHz}, \mathrm{CDCl}_{3}\right) \delta 133.6,131.9,131.5,128.8,127.7,127.2$, $126.3,125.6,125.3,122.9,69.5,36.9,32.4$. The spectroscopic data is in agreement with that previously reported. ${ }^{6}$<smiles>COCCCN1C(=O)c2ccccc2C1=O</smiles>

3-(1,3-Dioxoisoindolin-2-yl)propyl methanesulfonate (8d). General procedure A, 20 mmol scale. The crude product was recrystallized with $\mathrm{CH}_{2} \mathrm{Cl}_{2} / \mathrm{EtOH}$ to afford $\mathbf{8 d}$ in $81 \%$ yield (4.61 g) as a white solid. ${ }^{1} \mathrm{H}$ NMR $\left(400 \mathrm{MHz}, \mathrm{CDCl}_{3}\right) \delta 7.88-7.84(\mathrm{~m}, 2 \mathrm{H}), 7.77-7.74(\mathrm{~m}, 2 \mathrm{H}), 4.28$ (t, $J=6.4 \mathrm{~Hz}, 2 \mathrm{H}), 3.85(\mathrm{t}, J=6.4 \mathrm{~Hz}, 2 \mathrm{H}), 3.06(\mathrm{~s}, 3 \mathrm{H}), 2.19-2.13(\mathrm{~m}, 2 \mathrm{H}) ;{ }^{13} \mathrm{C} \mathrm{NMR}(100$ $\left.\mathrm{MHz}, \mathrm{CDCl}_{3}\right) \delta 168.2,134.1,131.8,123.3,67.1,37.3,34.3,28.1$. IR (neat): 1702, 1347, 1174, 1058, 981, 926, 877, 832, 721, $711 \mathrm{~cm}^{-1}$. HRMS (ESI-TOF) $\mathrm{m} / \mathrm{z}:[\mathrm{M}+\mathrm{Na}]^{+}$calcd for $\mathrm{C}_{12} \mathrm{H}_{13} \mathrm{NO}_{5} \mathrm{NaS}$ 306.0407; found 306.0407.

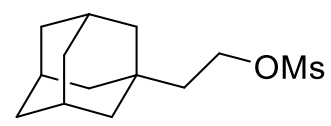

$8 \mathrm{e}$

2-((3r,5r,7r)-Adamantan-1-yl)ethyl methanesulfonate (8e). General procedure A, 5 mmol scale. The crude product was purified by column chromatography on silica gel (eluent: petroleum ether: ethyl acetate $=10: 1$ to $5: 1)$ to afford $8 \mathbf{e}$ in $97 \%$ isolated yield $(1.25 \mathrm{~g})$ as a light yellow oil. ${ }^{1} \mathrm{H}$ NMR (400 MHz, $\left.\mathrm{CDCl}_{3}\right) \delta 4.29$ (t, $\left.J=7.2 \mathrm{~Hz}, 2 \mathrm{H}\right), 3.00$ (s, 3H), 1.97 (s, 
3H), 1.73-1.70 (m, 3H), 1.65-1.62 (m, 3H), 1.57-1.54 (m, 8H); $\left.{ }^{13} \mathrm{C} \mathrm{NMR} \mathrm{(100} \mathrm{MHz,} \mathrm{CDCl}_{3}\right) \delta$ 66.7, 42.6, 42.2, 37.3, 36.7, 31.7, 28.3. IR (neat): 2898, 2846, 1451, 1351, 1170, 974, 949, 933, 840, 814, $789 \mathrm{~cm}^{-1}$. HRMS (ESI-TOF) m/z: [M+Na $]^{+}$calcd for $\mathrm{C}_{13} \mathrm{H}_{22} \mathrm{O}_{3} \mathrm{NaS} 281.1182$; found 281.1188 .

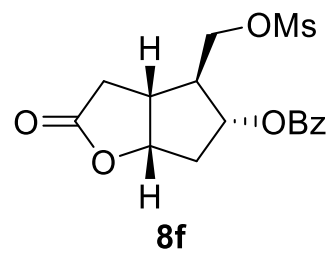

(3aR,4S,5R,6aS)-4-(((Methylsulfonyl)oxy)methyl)-2-oxohexahydro-2H-

cyclopenta[b]furan-5-yl benzoate (8f). General procedure A, $3.6 \mathrm{mmol}$ scale. The crude product was purified by column chromatography on silica gel (eluent: petroleum ether: ethyl acetate $=1: 3$ to $1: 5)$ to afford $\mathbf{8 f}$ in $96 \%$ isolated yield (1.23 g) as a white solid. ${ }^{1} \mathrm{H}$ NMR (400 $\left.\mathrm{MHz}, \mathrm{CDCl}_{3}\right) \delta$ 8.00-7.98 (m, 2H), 7.60-7.56 (m, 1H), 7.47-7.43 (m, 2H), 5.40-5.36 (m, 1H), 5.10-5.08 (m, 1H), $4.31(\mathrm{~d}, J=5.6 \mathrm{~Hz}, 2 \mathrm{H}), 3.06(\mathrm{~s}, 3 \mathrm{H}), 2.99-2.89(\mathrm{~m}, 2 \mathrm{H}), 2.60-2.48(\mathrm{~m}$, 3H), 2.39-2.35 (m, 1H); ${ }^{13} \mathrm{C}$ NMR $\left(100 \mathrm{MHz}, \mathrm{CDCl}_{3}\right) \delta 175.9,165.8,133.4,129.5,129.1$, $128.5,83.9,76.6,68.5,51.8,40.2,38.0,37.3,35.5$. IR (neat): 1765, 1712, 1350, 1277, 1171, 1115, 978, 926, $718 \mathrm{~cm}^{-1}$. HRMS (ESI-TOF) m/z: [M+Na $]^{+}$calcd for $\mathrm{C}_{16} \mathrm{H}_{18} \mathrm{O}_{7} \mathrm{NaS} 377.0665$; found 377.0661 .<smiles>CCc1ccc(CCOC)nc1</smiles>

2-(5-Ethylpyridin-2-yl)ethyl methanesulfonate (8g). General procedure A, 10 mmol scale. The crude product was purified by column chromatography on silica gel (eluent: petroleum ether: ethyl acetate $=1: 1)$ to afford $8 \mathrm{~g}$ in $89 \%$ isolated yield $(2.03 \mathrm{~g})$ as a yellow oil. ${ }^{1} \mathrm{H}$ NMR $\left(400 \mathrm{MHz}, \mathrm{CDCl}_{3}\right) \delta 8.38(\mathrm{~s}, 1 \mathrm{H}), 7.46(\mathrm{~d}, J=8.0 \mathrm{~Hz}, 1 \mathrm{H}), 7.15(\mathrm{~d}, J=8.0 \mathrm{~Hz}, 1 \mathrm{H}), 4.63(\mathrm{t}, J$ $=6.4 \mathrm{~Hz}, 2 \mathrm{H}), 3.17(\mathrm{t}, J=6.4 \mathrm{~Hz}, 2 \mathrm{H}), 2.91(\mathrm{~s}, 3 \mathrm{H}), 2.61(\mathrm{q}, J=7.6 \mathrm{~Hz}, 2 \mathrm{H}), 1.22(\mathrm{t}, J=7.6$ $\mathrm{Hz}, 3 \mathrm{H}) ;{ }^{13} \mathrm{C} \mathrm{NMR}\left(100 \mathrm{MHz}, \mathrm{CDCl}_{3}\right) \delta 153.2,148.5,136.9,135.4,122.8,68.9,36.4,25.0$, 14.8. IR (neat): $2966,1487,1348,1170,954,908,803 \mathrm{~cm}^{-1}$. HRMS (ESI-TOF) m/z: $[\mathrm{M}+\mathrm{H}]^{+}$ calcd for $\mathrm{C}_{10} \mathrm{H}_{16} \mathrm{NO}_{3} \mathrm{~S} 230.0845$; found 230.0847 . 


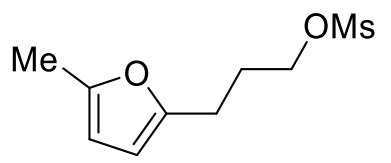

$8 \mathrm{~h}$

3-(5-Methylfuran-2-yl)propyl methanesulfonate (8h). General procedure B, $10 \mathrm{mmol}$ scale. The crude product was purified by column chromatography on silica gel (eluent: petroleum ether: ethyl acetate $=5: 1)$ to afford $\mathbf{8 h}$ in $63 \%$ isolated yield $(1.38 \mathrm{~g})$ over two steps as a yellow oil. ${ }^{1} \mathrm{H}$ NMR (400 MHz, $\left.\mathrm{CDCl}_{3}\right) \delta 5.91-5.85$ (m, 2H), 4.25 (t, $\left.J=6.4 \mathrm{~Hz}, 2 \mathrm{H}\right), 3.00(\mathrm{~s}, 3 \mathrm{H})$, $2.72(\mathrm{t}, J=7.2 \mathrm{~Hz}, 2 \mathrm{H}), 2.24(\mathrm{~s}, 3 \mathrm{H}), 2.10-2.03(\mathrm{~m}, 2 \mathrm{H}) ;{ }^{13} \mathrm{C} \mathrm{NMR}\left(100 \mathrm{MHz}, \mathrm{CDCl}_{3}\right) \delta 151.9$, 150.7, 106.3, 105.9, 69.0, 37.1, 27.6, 23.8, 13.4. IR (neat): 2922, 1566, 1350, 1170, 972, 941, 920, 830, $784 \mathrm{~cm}^{-1}$. HRMS (EI-TOF) m/z: [M] $]^{+}$calcd for $\mathrm{C}_{9} \mathrm{H}_{14} \mathrm{O}_{4} \mathrm{~S}$ 218.0607; found 218.0607.<smiles>COCCCc1ccccc1</smiles>

$8 \mathbf{i}$

3-Phenylpropyl methanesulfonate (8i). General procedure B, $20 \mathrm{mmol}$ scale. The crude product was purified by column chromatography on silica gel (eluent: petroleum ether: ethyl acetate $=5: 1)$ to afford $\mathbf{8 i}$ in $56 \%$ isolated yield (2.40 g) over two steps as a light yellow oil. ${ }^{1} \mathrm{H}$ NMR (400 MHz, $\left.\mathrm{CDCl}_{3}\right) \delta$ 7.31-7.17 (m, 5H), $4.21(\mathrm{t}, J=6.0 \mathrm{~Hz}, 2 \mathrm{H}), 2.96(\mathrm{~s}, 3 \mathrm{H}), 2.74(\mathrm{t}, J$ $=7.2 \mathrm{~Hz}, 2 \mathrm{H}), 2.10-2.03(\mathrm{~m}, 2 \mathrm{H}) ;{ }^{13} \mathrm{C} \mathrm{NMR}\left(100 \mathrm{MHz}, \mathrm{CDCl}_{3}\right) \delta 140.2,128.4,128.3,126.2$, $69.1,37.1,31.4,30.5$. The spectroscopic data is in agreement with that previously reported. ${ }^{7}$

\section{Synthesis of 8j}

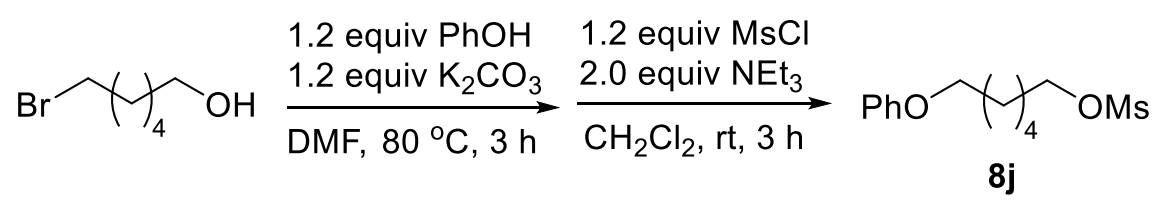

To a solution of PhOH (1.13g, $12 \mathrm{mmol})$ in DMF $(30 \mathrm{~mL})$ was added $\mathrm{K}_{2} \mathrm{CO}_{3}(1.66 \mathrm{~g}, 12$ $\mathrm{mmol})$ at room temperature under air. After stirring for $0.5 \mathrm{~h}, 6$-bromo-1-hexanol $(1.3 \mathrm{~mL}, 10$ mmol) was added to the mixture. The mixture was then stirred at $80^{\circ} \mathrm{C}$ (oil bath) for $3 \mathrm{~h}$. After the starting material was completely consumed, the mixture was quenched with saturated $\mathrm{NH}_{4} \mathrm{Cl}$ solution, extracted with ethyl acetate, washed with $\mathrm{H}_{2} \mathrm{O}$ and brine, dried over anhydrous 
$\mathrm{Na}_{2} \mathrm{SO}_{4}$. The solvent was evaporated under the reduced pressure and the residue was purified by column chromatography on silica gel (eluent: petroleum ether: ethyl acetate $=10: 1$ ) to afford the product which was used for the next step.

To a solution of the above product in $\mathrm{CH}_{2} \mathrm{Cl}_{2}(30 \mathrm{~mL})$ were added $\mathrm{NEt}_{3}(2.78 \mathrm{~mL}, 20 \mathrm{mmol})$ and $\mathrm{MsCl}(0.93 \mathrm{~mL}, 12 \mathrm{mmol})$ at room temperature under air. The mixture was stirred for $3 \mathrm{~h}$ at room temperature. After the starting material was completely consumed, the mixture was quenched with saturated $\mathrm{NH}_{4} \mathrm{Cl}$ solution, extracted with ethyl acetate, washed with brine, dried over anhydrous $\mathrm{Na}_{2} \mathrm{SO}_{4}$. The solvent was evaporated under the reduced pressure and the residue was purified by column chromatography on silica gel (eluent: petroleum ether: ethyl acetate $=10: 1)$ to afford 6-phenoxyhexyl methanesulfonate $(\mathbf{8 j})$ in $86 \%$ isolated yield $(2.33 \mathrm{~g})$ over two steps as a light yellow oil. ${ }^{1} \mathrm{H}$ NMR (400 MHz, $\left.\mathrm{CDCl}_{3}\right) \delta$ 7.29-7.25 (m, 2H), 6.94$6.87(\mathrm{~m}, 3 \mathrm{H}), 4.22(\mathrm{t}, J=6.4 \mathrm{~Hz}, 2 \mathrm{H}), 3.95(\mathrm{t}, J=6.4 \mathrm{~Hz}, 2 \mathrm{H}), 2.97(\mathrm{~s}, 3 \mathrm{H}), 1.82-1.72(\mathrm{~m}, 4$ $\mathrm{H}), 1.52-1.46(\mathrm{~m}, 4 \mathrm{H}) ;{ }^{13} \mathrm{C} \mathrm{NMR}\left(100 \mathrm{MHz}, \mathrm{CDCl}_{3}\right) \delta 158.8,129.3,120.4,114.3,69.9,67.3$, $37.1,28.9,28.9,25.4,25.1$. The spectroscopic data is in agreement with that previously reported. ${ }^{8}$

\section{Synthesis of $8 k$}
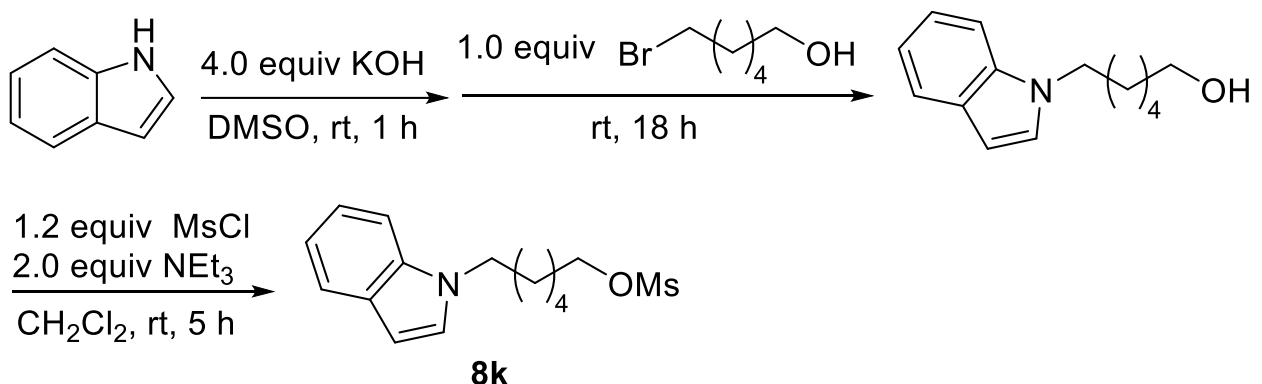

To a solution of indole $(3.51 \mathrm{~g}, 30 \mathrm{mmol})$ in DMSO $(50 \mathrm{~mL})$ was added $\mathrm{KOH}(2.24 \mathrm{~g}, 40$ $\mathrm{mmol})$ at room temperature under air. After stirring for $1 \mathrm{~h}, 6$-bromo-1-hexanol $(1.3 \mathrm{~mL}, 10$ mmol) was added to the mixture. The mixture was then stirred at room temperature for $18 \mathrm{~h}$. After the starting material was completely consumed, the mixture was quenched with saturated $\mathrm{NH}_{4} \mathrm{Cl}$ solution, extracted with ethyl acetate, washed with $\mathrm{H}_{2} \mathrm{O}$ and brine, dried over anhydrous $\mathrm{Na}_{2} \mathrm{SO}_{4}$. The solvent was evaporated under the reduced pressure and the residue was purified by column chromatography on silica gel (eluent: petroleum ether: ethyl acetate $=10: 1$ ) to afford 
the product as a light yellow oil, which was used for the next step.

To a solution of the above product $(434.6 \mathrm{mg}, 2 \mathrm{mmol})$ in $\mathrm{CH}_{2} \mathrm{Cl}_{2}(20 \mathrm{~mL})$ was added $\mathrm{NEt}_{3}$ $(0.56 \mathrm{~mL}, 4 \mathrm{mmol})$ at room temperature under air. The mixture was then stirred at $0{ }^{\circ} \mathrm{C}$ and $\mathrm{MsCl}(0.19 \mathrm{~mL}, 2.4 \mathrm{mmol})$ was added to the mixture. After addition, the mixture was then stirred at room temperature for $5 \mathrm{~h}$. After the starting material was completely consumed, the mixture was quenched with saturated $\mathrm{NH}_{4} \mathrm{Cl}$ solution, extracted with $\mathrm{CH}_{2} \mathrm{Cl}_{2}$, washed with $\mathrm{H}_{2} \mathrm{O}$ and brine, dried over anhydrous $\mathrm{Na}_{2} \mathrm{SO}_{4}$. The solvent was evaporated under the reduced pressure and the residue was purified by column chromatography on silica gel (eluent: petroleum ether: ethyl acetate $=10: 1$ to $5: 1)$ to afford 6-(1H-indol-1-yl)hexyl methanesulfonate $(\mathbf{8 k})$ in $93 \%$ isolated yield $(550.1 \mathrm{mg})$ as a yellow oil. ${ }^{1} \mathrm{H} \mathrm{NMR}\left(400 \mathrm{MHz}, \mathrm{CDCl}_{3}\right) \delta 7.60(\mathrm{~d}$, $J=7.6 \mathrm{~Hz}, 1 \mathrm{H}), 7.30(\mathrm{~d}, J=8.4 \mathrm{~Hz}, 1 \mathrm{H}), 7.19-7.15(\mathrm{~m}, 1 \mathrm{H}), 7.09-7.04(\mathrm{~m}, 2 \mathrm{H}), 6.46(\mathrm{~d}, J=$ $3.2 \mathrm{~Hz}, 1 \mathrm{H}), 4.11-4.04(\mathrm{~m}, 4 \mathrm{H}), 2.86(\mathrm{~s}, 3 \mathrm{H}), 1.82-1.75(\mathrm{~m}, 2 \mathrm{H}), 1.67-1.60(\mathrm{~m}, 2 \mathrm{H}), 1.39-1.23$ $(\mathrm{m}, 4 \mathrm{H}) ;{ }^{13} \mathrm{C} \mathrm{NMR}\left(100 \mathrm{MHz}, \mathrm{CDCl}_{3}\right) \delta 135.7,128.4,127.6,121.2,120.7,119.0,109.2,100.7$, 69.8, 45.9, 36.9, 29.8, 28.7, 26.1, 24.9. IR (neat): 2936, 2860, 1349, 1171, 946, 918, $740 \mathrm{~cm}^{-1}$. HRMS (ESI-TOF) m/z: [M+Na] $]^{+}$calcd for $\mathrm{C}_{15} \mathrm{H}_{21} \mathrm{NO}_{3} \mathrm{NaS} 318.1134$; found 318.1133.

\section{Synthesis of 81}

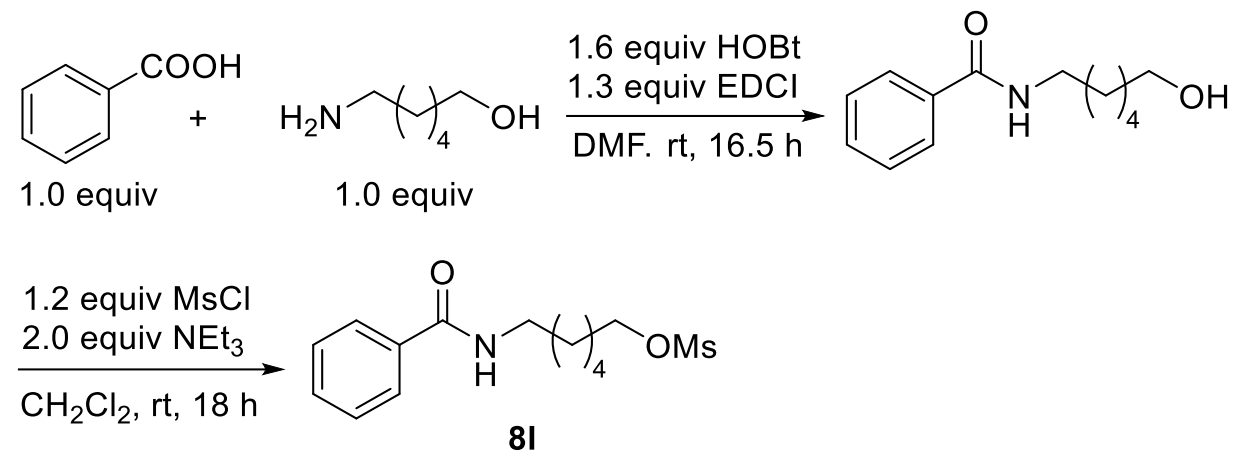

To a solution of benzoic acid $(1.22 \mathrm{~g}, 10 \mathrm{mmol})$ and 6-amino-1-hexanol (1.32 $\mathrm{mL}, 10 \mathrm{mmol})$ in DMF (60 mL) was added EDCI (1-(3-Dimethylaminopropyl)-3-ethylcarbodiimide) (2.02 g, $13 \mathrm{mmol}$ ) and HOBt (1-hydroxybenzotriazole) $(2.16 \mathrm{~g}, 16 \mathrm{mmol})$ at room temperature under air. The mixture was then stirred at room temperature for $16.5 \mathrm{~h}$. After the starting material was completely consumed, the mixture was quenched with $\mathrm{H}_{2} \mathrm{O}$, extracted with $\mathrm{CH}_{2} \mathrm{Cl}_{2}$, washed with $\mathrm{H}_{2} \mathrm{O}$ and brine, dried over anhydrous $\mathrm{Na}_{2} \mathrm{SO}_{4}$. The solvent was evaporated under the reduced pressure and the residue was purified by column chromatography on silica gel (eluent: 
petroleum ether: ethyl acetate $=2: 1$ to ethyl acetate: methanol $=20: 1$ to $10: 1)$ to afford the product as a white solid, which was used for the next step.

To a solution of the above product $(442.6 \mathrm{mg}, 2 \mathrm{mmol})$ in $\mathrm{CH}_{2} \mathrm{Cl}_{2}(10 \mathrm{~mL})$ was added $\mathrm{NEt}_{3}$ $(0.56 \mathrm{~mL}, 4 \mathrm{mmol})$ at room temperature under air. The mixture was then stirred at $0{ }^{\circ} \mathrm{C}$ and $\mathrm{MsCl}(0.19 \mathrm{~mL}, 2.4 \mathrm{mmol})$ was added to the mixture. After addition, the mixture was then stirred at room temperature for $18 \mathrm{~h}$. After the starting material was completely consumed, the mixture was quenched with saturated $\mathrm{NH}_{4} \mathrm{Cl}$ solution, extracted with $\mathrm{CH}_{2} \mathrm{Cl}_{2}$, washed with $\mathrm{H}_{2} \mathrm{O}$ and brine, dried over anhydrous $\mathrm{Na}_{2} \mathrm{SO}_{4}$. The solvent was evaporated under the reduced pressure and the residue was purified by column chromatography on silica gel (eluent: petroleum ether: ethyl acetate $=2: 1$ to $1: 2$ ) to afford 6-benzamidohexyl methanesulfonate $(\mathbf{8 1})$ in $91 \%$ isolated yield $(542.4 \mathrm{mg})$ as a white solid. ${ }^{1} \mathrm{H} \mathrm{NMR}\left(400 \mathrm{MHz}, \mathrm{CDCl}_{3}\right) \delta$ 7.79-7.77 (m, 2H), 7.50-7.46 (m, 1H), 7.40 (t, $J=7.6 \mathrm{~Hz}, 2 \mathrm{H}), 6.66(\mathrm{bs}, 1 \mathrm{H}), 4.20(\mathrm{t}, J=6.8 \mathrm{~Hz}, 2 \mathrm{H}), 3.42$ $(\mathrm{q}, J=6.8 \mathrm{~Hz}, 2 \mathrm{H}), 2.98(\mathrm{~s}, 3 \mathrm{H}), 1.77-1.70(\mathrm{~m}, 2 \mathrm{H}), 1.65-1.58(\mathrm{~m}, 2 \mathrm{H}), 1.47-1.39(\mathrm{~m}, 4 \mathrm{H}) ;{ }^{13} \mathrm{C}$ NMR (100 MHz, $\left.\mathrm{CDCl}_{3}\right) \delta 167.5,134.5,131.2,128.3,126.8,69.9,39.6,37.1,29.3,28.8,26.1$, 24.9. IR (neat): $3330,2936,2857,1629,1532,1345,1163,972,954,839,686 \mathrm{~cm}^{-1}$. HRMS (ESI-TOF) m/z: [M+Na] ${ }^{+}$calcd for $\mathrm{C}_{14} \mathrm{H}_{21} \mathrm{NO}_{4} \mathrm{NaS} 322.1084$; found 322.1076.

\section{Reaction of 1a under the standard conditions for alkyl halides reported in our previous paper}

1) Reaction of 1a under the standard conditions for alkyl chlorides reported in our previous paper

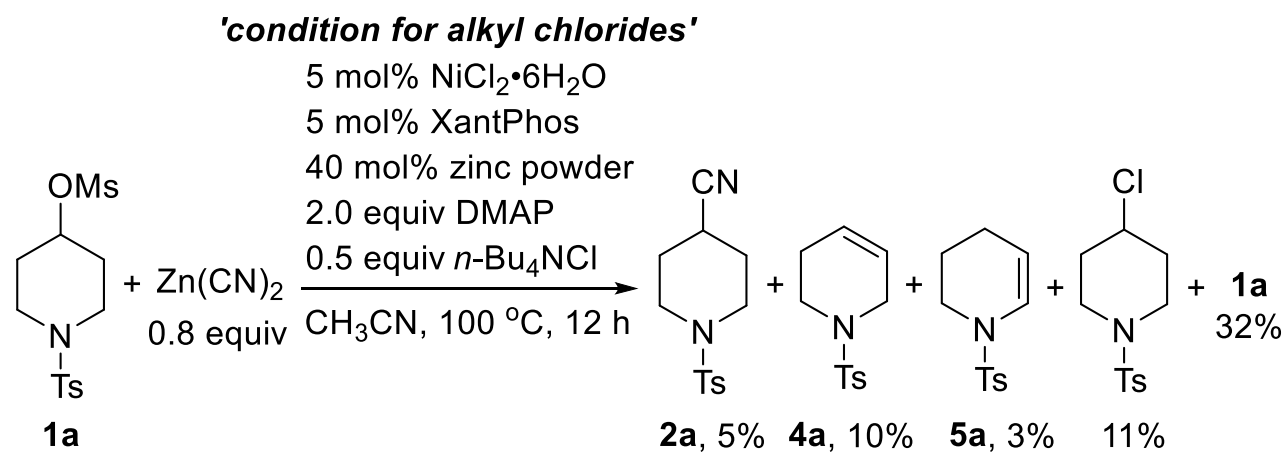

In a nitrogen-filled glove box, $\mathrm{NiCl}_{2} \cdot 6 \mathrm{H}_{2} \mathrm{O}(2.4 \mathrm{mg}, 0.01 \mathrm{mmol})$, DMAP (48.9 mg, 0.4 $\mathrm{mmol}), \mathrm{Zn}(\mathrm{CN})_{2}(18.8 \mathrm{mg}, 0.16 \mathrm{mmol})$, zinc powder (5.2 mg, $\left.0.08 \mathrm{mmol}\right), n-\mathrm{Bu} 4 \mathrm{NCl}(27.8 \mathrm{mg}$, 
$0.1 \mathrm{mmol})$, XantPhos (5.8 mg, $0.01 \mathrm{mmol}), \mathbf{1 a}(66.7 \mathrm{mg}, 0.2 \mathrm{mmol})$ and $\mathrm{CH}_{3} \mathrm{CN}(0.4 \mathrm{~mL})$ were added sequentially to a $4 \mathrm{~mL}$ screw-cap vial. The vial cap was then securely fitted and taken outside the glove box. After the reaction mixture was stirred at $100{ }^{\circ} \mathrm{C}$ (oil bath) for $12 \mathrm{~h}$, the mixture was filtered through a pad of silica gel and washed with $\mathrm{CH}_{2} \mathrm{Cl}_{2}$. The solvent was evaporated under the reduced pressure and the yield were determined by ${ }^{1} \mathrm{H}$ NMR using 1,3,5trimethoxybenzene (33.6 mg, $0.2 \mathrm{mmol}$ ) as an internal standard, the NMR yield of $2 \mathbf{a}$ was $5 \%$, the NMR yield of $\mathbf{4 a}$ was $10 \%$, the NMR yield of $\mathbf{5 a}$ was 3\%, the NMR yield of 4-chloro-1tosylpiperidine was $11 \%$, and $\mathbf{1 a}$ was recovered in $32 \%$ yield.

The results indicated that under these conditions, trace of the desired product $\mathbf{2 a}$ was formed.

2) Reaction of 1a under standard conditions for alkyl bromides reported in our previous paper 'condition for alkyl bromides'

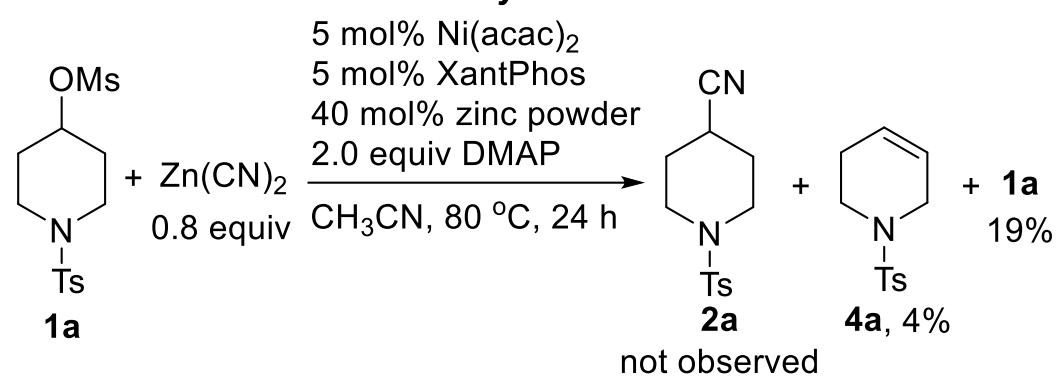

In a nitrogen-filled glove box, $\mathrm{Ni}(\mathrm{acac})_{2}(2.6 \mathrm{mg}, 0.01 \mathrm{mmol}), \mathrm{DMAP}(48.9 \mathrm{mg}, 0.4 \mathrm{mmol})$, $\mathrm{Zn}(\mathrm{CN})_{2}(18.8 \mathrm{mg}, 0.16 \mathrm{mmol})$, zinc powder (5.2 mg, $\left.0.08 \mathrm{mmol}\right)$, XantPhos $(5.8 \mathrm{mg}, 0.01$ $\mathrm{mmol}), \mathbf{1 a}(66.7 \mathrm{mg}, 0.2 \mathrm{mmol})$ and $\mathrm{CH}_{3} \mathrm{CN}(0.4 \mathrm{~mL})$ were added sequentially to a $4 \mathrm{~mL}$ screwcap vial. The vial cap was then securely fitted and taken outside the glove box. After the reaction mixture was stirred at $80{ }^{\circ} \mathrm{C}$ (oil bath) for $24 \mathrm{~h}$, the mixture was filtered through a pad of silica gel and washed with $\mathrm{CH}_{2} \mathrm{Cl}_{2}$. The solvent was evaporated under the reduced pressure and the yield were determined by ${ }^{1} \mathrm{H}$ NMR using 1,3,5-trimethoxybenzene (33.6 mg, $0.2 \mathrm{mmol}$ ) as an internal standard, no desired product (2a) was observed, the NMR yield of $4 \mathbf{a}$ was $4 \%$ and $1 \mathbf{a}$ was recovered in 19\% yield.

The results indicated that under these conditions, the desired product $\mathbf{2 a}$ was not formed. 


\section{Optimization studies for cyanation of secondary alkyl mesylates}

In a nitrogen-filled glove box, $\mathrm{NiCl}_{2} \cdot 6 \mathrm{H}_{2} \mathrm{O}(4.8 \mathrm{mg}, 0.02 \mathrm{mmol})$, DMAP (48.9 mg, 0.4 $\mathrm{mmol}), \mathrm{Zn}(\mathrm{CN})_{2}$ (37.6 mg, $\left.0.32 \mathrm{mmol}\right)$, zinc powder (10.5 mg, $\left.0.16 \mathrm{mmol}\right), n-\mathrm{Bu} 4 \mathrm{NI}(443.2$ mg, $1.2 \mathrm{mmol}$ ), XantPhos (13.9 mg, $0.024 \mathrm{mmol}), \mathbf{1 a}(133.4 \mathrm{mg}, 0.4 \mathrm{mmol})$ and $\mathrm{CH}_{3} \mathrm{CN}(2.0$ $\mathrm{mL}$ ) were added sequentially to a $4 \mathrm{~mL}$ screw-cap vial. The vial cap was then securely fitted and taken outside the glove box. After the reaction mixture was stirred at $100{ }^{\circ} \mathrm{C}$ (oil bath) for $10 \mathrm{~h}$, the mixture was filtered through a pad of silica gel and washed with $\mathrm{CH}_{2} \mathrm{Cl}_{2}$. The solvent was evaporated under the reduced pressure and the yields were determined by ${ }^{1} \mathrm{H}$ NMR using 1,3,5-trimethoxybenzene $(67.3 \mathrm{mg}, 0.4 \mathrm{mmol})$ as an internal standard.

Table S1 Effects of substrate concentration and solvents

\begin{tabular}{|c|c|c|c|c|c|c|c|c|}
\hline$\sum_{1 \mathrm{~N}}^{\mathrm{ON}}$ & $\begin{array}{r}+\mathrm{Zn}(\mathrm{CN})_{2} \\
0.8 \text { equiv }\end{array}$ & $\begin{array}{l}5 \mathrm{~mol} \% \\
6 \mathrm{~mol} \% \\
40 \mathrm{~mol} \% \\
1.0 \text { equi } \\
3.0 \text { equi } \\
\text { solvent, }\end{array}$ & $\begin{array}{l}\mathrm{iCl}_{2} \cdot 6 \mathrm{H}_{2} \mathrm{O} \\
\text { antPhos } \\
\text { zinc powder } \\
\text { DMAP } \\
\stackrel{n-\mathrm{Bu}_{4} \mathrm{NI}}{\mathrm{O}{ }^{\circ} \mathrm{C}, 10 \mathrm{~h}}\end{array}$ & $\begin{array}{l}\text { s } \\
\text { a }\end{array}$ & $\begin{array}{l}v^{\prime} \\
1 \\
\text { Ts }\end{array}$ & + & Ts & $5 a$ \\
\hline entry & substrate (M) & solvent & conversion (\%) & \multicolumn{5}{|c|}{ yield $(\%)^{a}$} \\
\hline 1 & 0.2 & $\mathrm{CH}_{3} \mathrm{CN}$ & 97 & $88,89^{b}$ & - & - & 2 & 4 \\
\hline 2 & 0.1 & $\mathrm{CH}_{3} \mathrm{CN}$ & 74 & 69 & - & - & - & 4 \\
\hline 3 & 0.2 & THF & 100 & - & 10 & 48 & - & 37 \\
\hline 4 & 0.2 & toluene & 100 & - & 12 & 50 & - & 32 \\
\hline 5 & 0.2 & dioxane & 100 & 69 & - & - & 14 & 17 \\
\hline 6 & 0.2 & DMF & 100 & 83 & - & - & 6 & - \\
\hline
\end{tabular}

aYields were determined by ${ }^{1} \mathrm{H}$ NMR using 1,3,5-trimethoxybenzene as an internal standard. ${ }^{b}$ Isolated yield.

Table S2 Effects of catalysts 


\begin{tabular}{|c|c|c|c|c|c|c|c|}
\hline & $\begin{array}{r}+\mathrm{Zn}(\mathrm{CN})_{2} \\
\quad 0.8 \text { equiv }\end{array}$ & $\begin{array}{l}5 \text { mol\% Ni catalyst } \\
6 \text { mol\% XantPhos } \\
40 \text { mol\% zinc powder } \\
1.0 \text { equiv DMAP } \\
3.0 \text { equiv } n-\mathrm{Bu}_{4} \mathrm{NI} \\
\mathrm{CH}_{3} \mathrm{CN}, 100^{\circ} \mathrm{C}, 10 \mathrm{~h}\end{array}$ & $\mathrm{~T}$ & & & Ts & \\
\hline entry & $\mathrm{Ni}$ catalyst & conversion (\%) & \multicolumn{5}{|c|}{ yield $(\%)^{a}$} \\
\hline 1 & $\mathrm{NiCl}_{2} \cdot 6 \mathrm{H}_{2} \mathrm{O}$ & 97 & $88,89^{b}$ & - & - & 2 & 4 \\
\hline 2 & $\mathrm{NiCl}_{2}(\mathrm{DME})$ & 100 & 72 & - & 5 & - & 17 \\
\hline 3 & $\mathrm{NiCl}_{2}$ & 97 & 60 & - & 5 & - & 31 \\
\hline 4 & $\mathrm{Nil}_{2}$ & 97 & 70 & - & 5 & - & 18 \\
\hline
\end{tabular}

aYields were determined by ${ }^{1} \mathrm{H}$ NMR using 1,3,5-trimethoxybenzene as an internal standard. ${ }^{b}$ Isolated yield.

Table S3 Effects of ligands

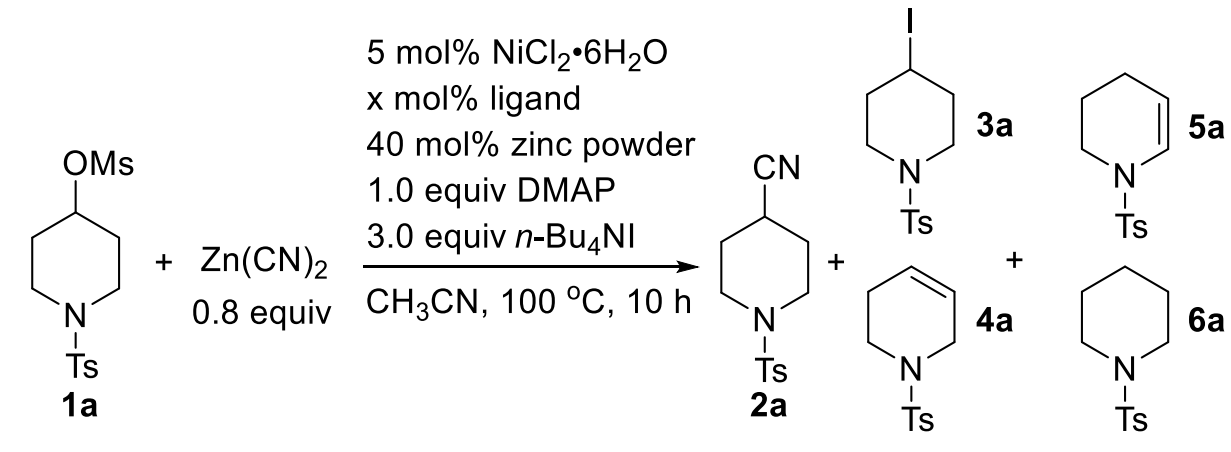

\begin{tabular}{cclcccccc}
\hline & & & & \multicolumn{5}{c}{${\text { yield }(\%)^{a}}$} \\
entry & $\mathbf{x}$ & ligand & conversion (\%) & $\mathbf{2 a}$ & $\mathbf{3 a}$ & $\mathbf{4 a}$ & $\mathbf{5 a}$ & $\mathbf{6 a}$ \\
\hline 1 & 6 & XantPhos & 97 & $88,89^{b}$ & - & - & 2 & 4 \\
2 & 6 & NiXantPhos & 98 & 87 & - & 1 & 1 & 5 \\
3 & 6 & dppf & 95 & 74 & - & - & 7 & 12 \\
4 & 6 & $2,2^{\prime}-$ bpy & 92 & - & 22 & 31 & - & 33 \\
5 & 12 & $\mathrm{PCy}_{3}$ & 94 & - & 21 & 35 & - & 34 \\
\hline
\end{tabular}

${ }^{a}$ Yields were determined by ${ }^{1} \mathrm{H}$ NMR using 1,3,5-trimethoxybenzene as an internal standard. ${ }^{b}$ Isolated yield.

Table S4 Effects of basic additives 


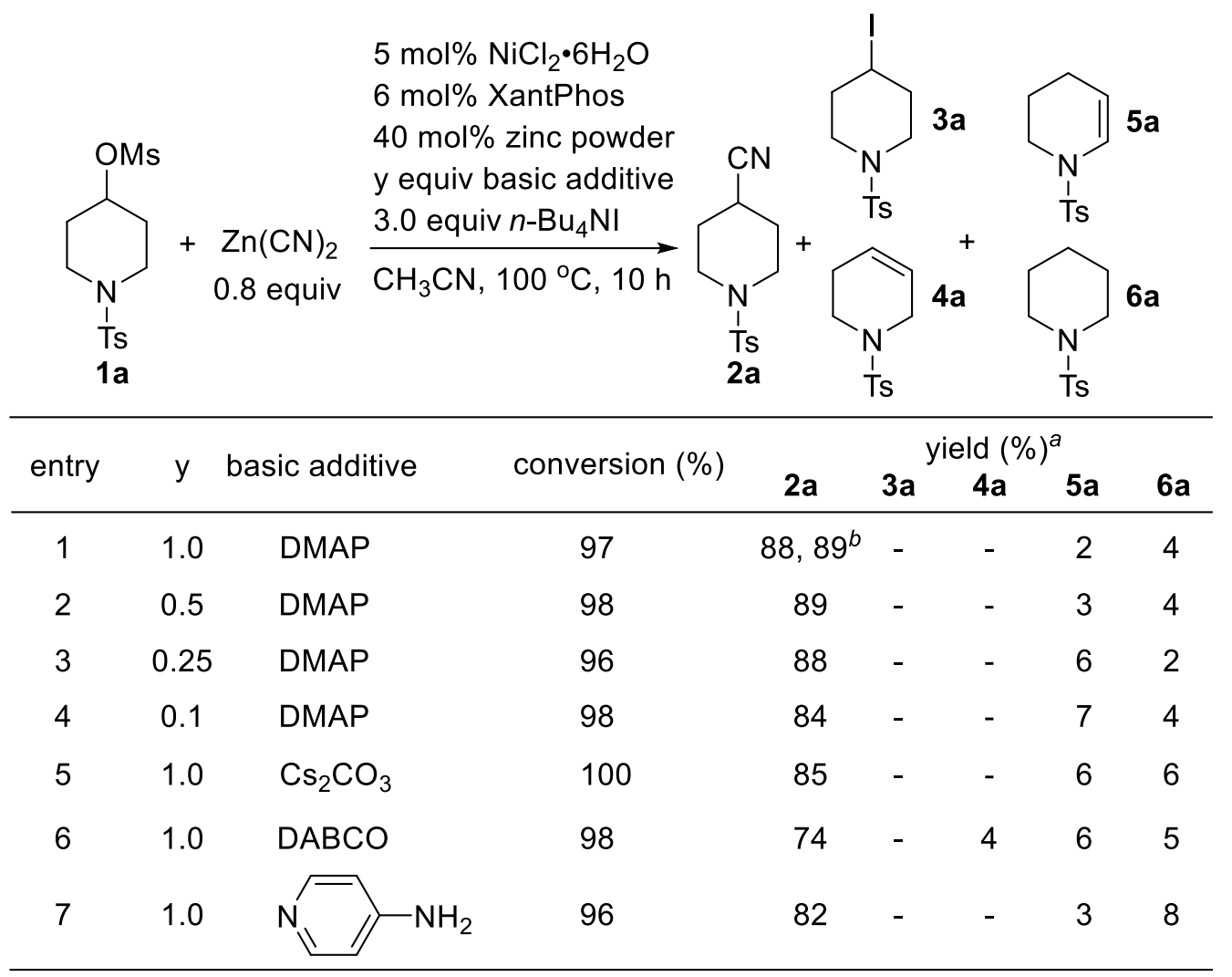

${ }^{a}$ Yields were determined by ${ }^{1} \mathrm{H}$ NMR using 1,3,5-trimethoxybenzene as an internal standard. ${ }^{b}$ Isolated yield.

Table S5 Effects of additives of $n$-Bu ${ }_{4} \mathrm{NX}$ derivatives 


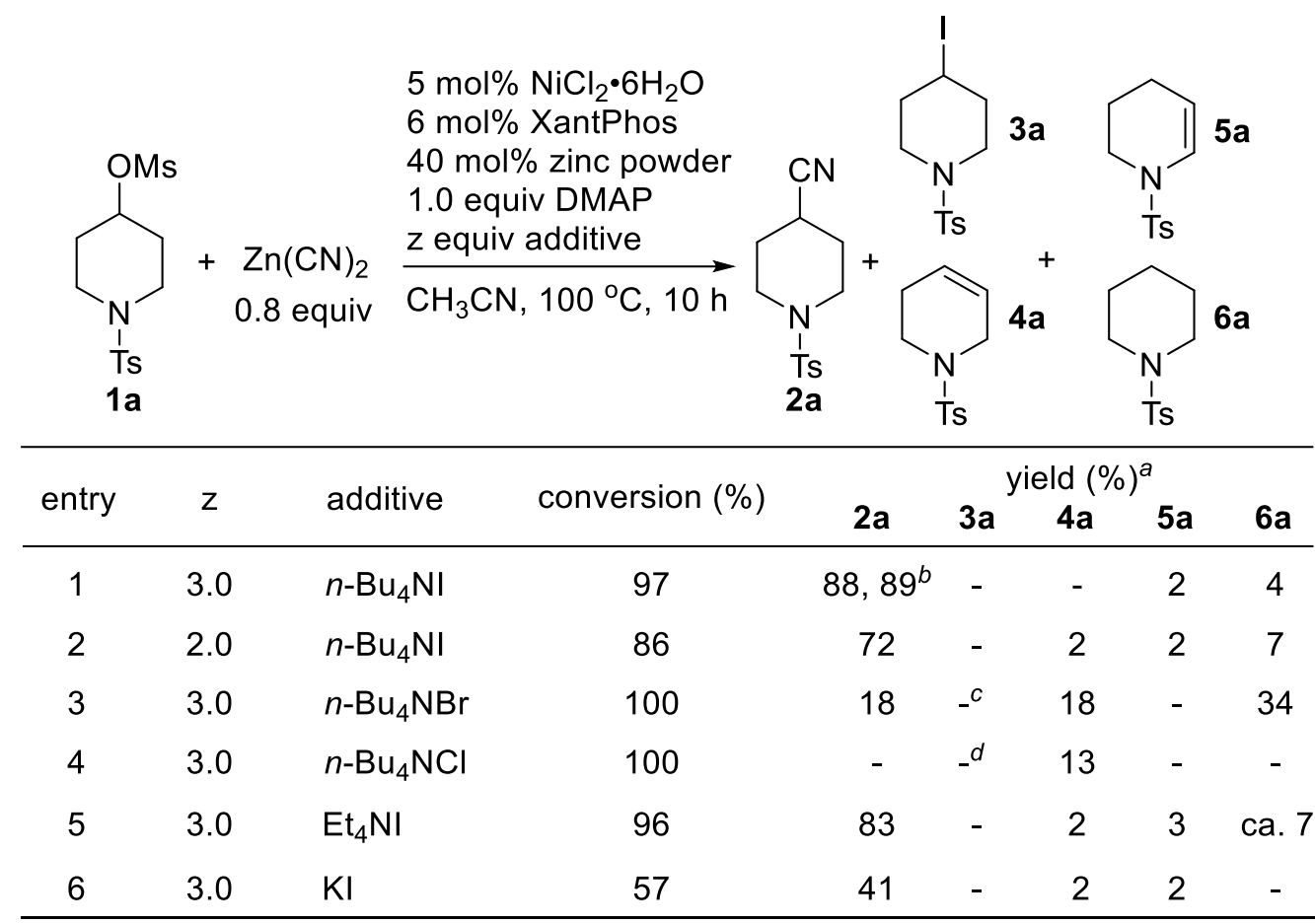

${ }^{a}$ Yields were determined by ${ }^{1} \mathrm{H}$ NMR using 1,3,5-trimethoxybenzene as an internal standard. ${ }^{b}$ Isolated yield. ${ }^{c} 4$-Bromo-1-tosylpiperidine was formed in $28 \%$ yield. ${ }^{d} 4$ Chloro-1-tosylpiperidine was formed in $84 \%$ yield.

Table S6 Effects of reducing agents and temperature

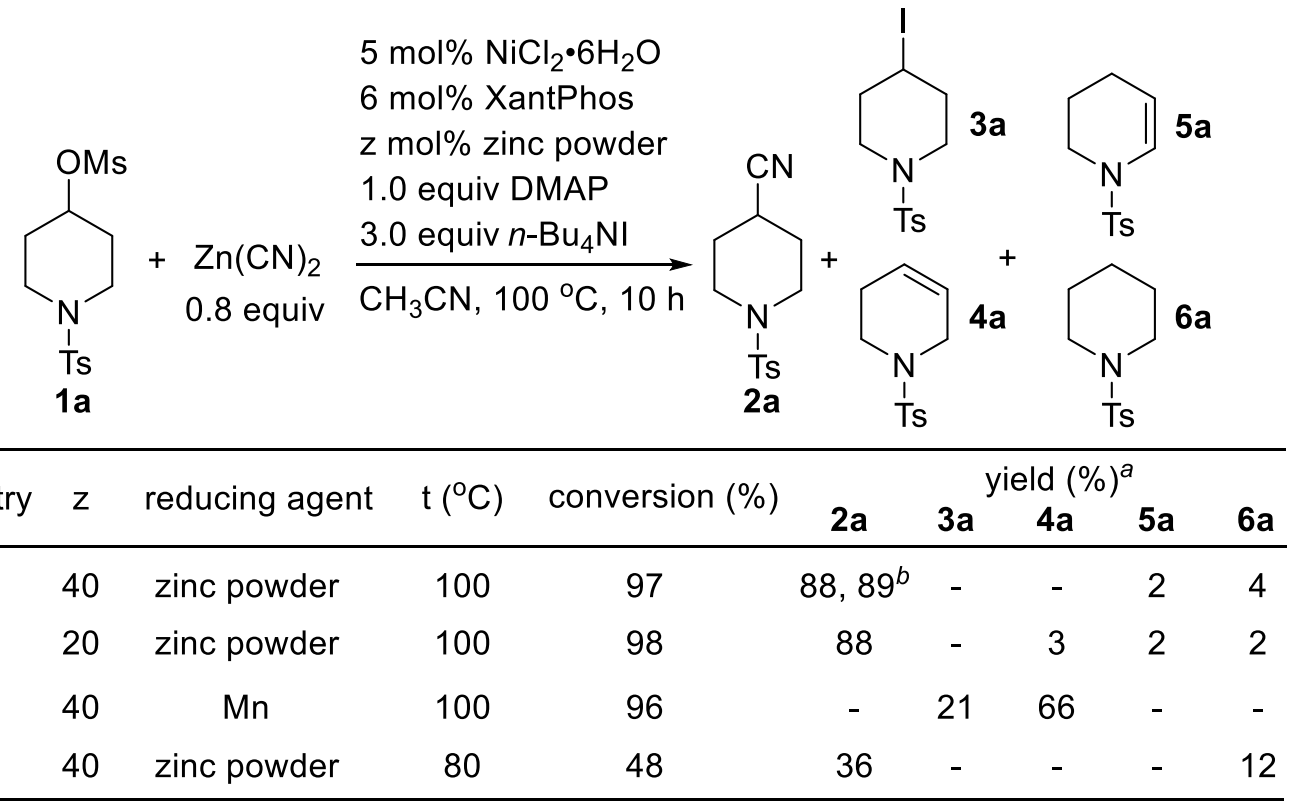

${ }^{a}$ Yields were determined by ${ }^{1} \mathrm{H}$ NMR using 1,3,5-trimethoxybenzene as an internal standard. ${ }^{b}$ Isolated yield.

Table S7 Control experiments 


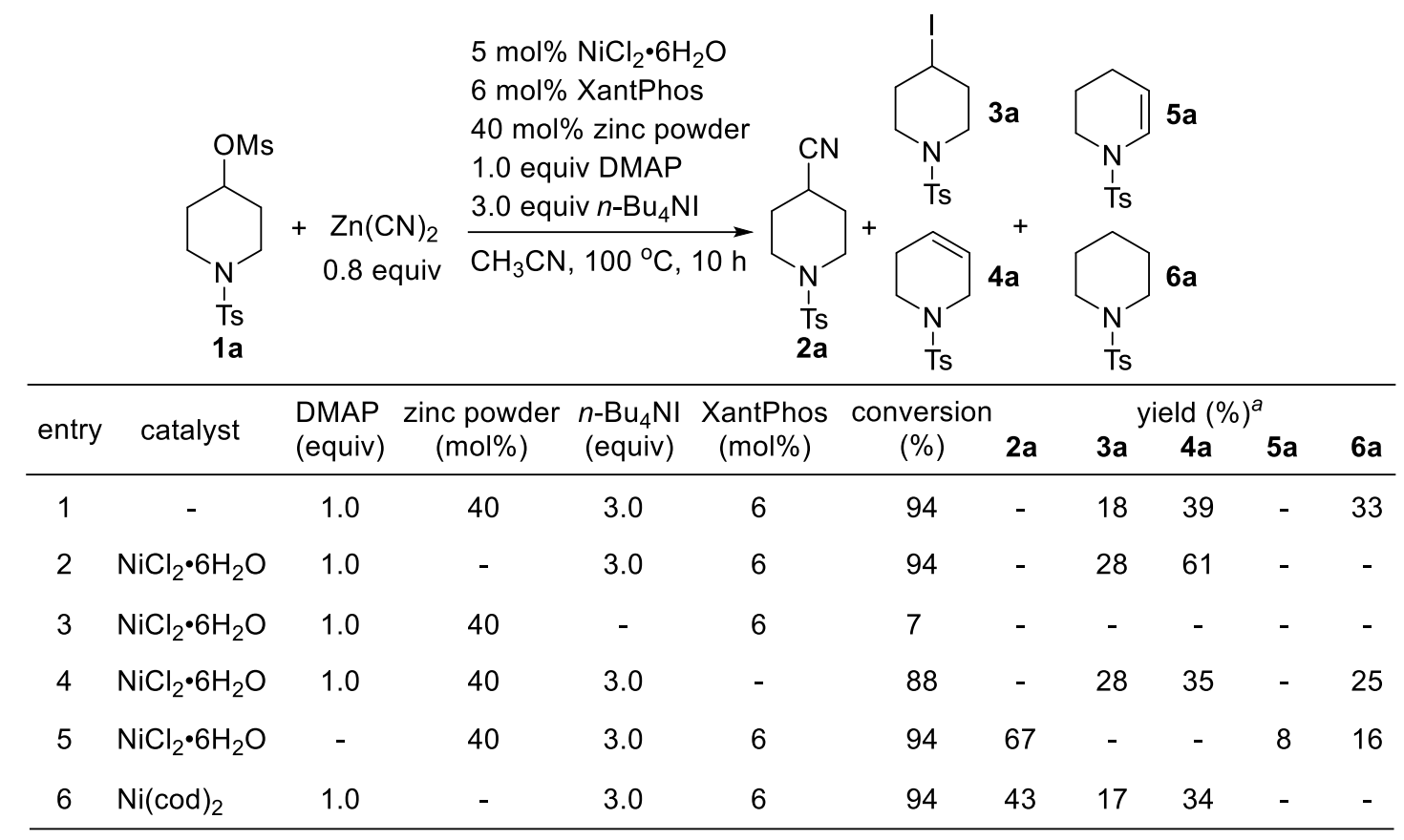

aYields were determined by ${ }^{1} \mathrm{H}$ NMR using 1,3,5-trimethoxybenzene as an internal standard.

Table S8 Effects of leaving groups

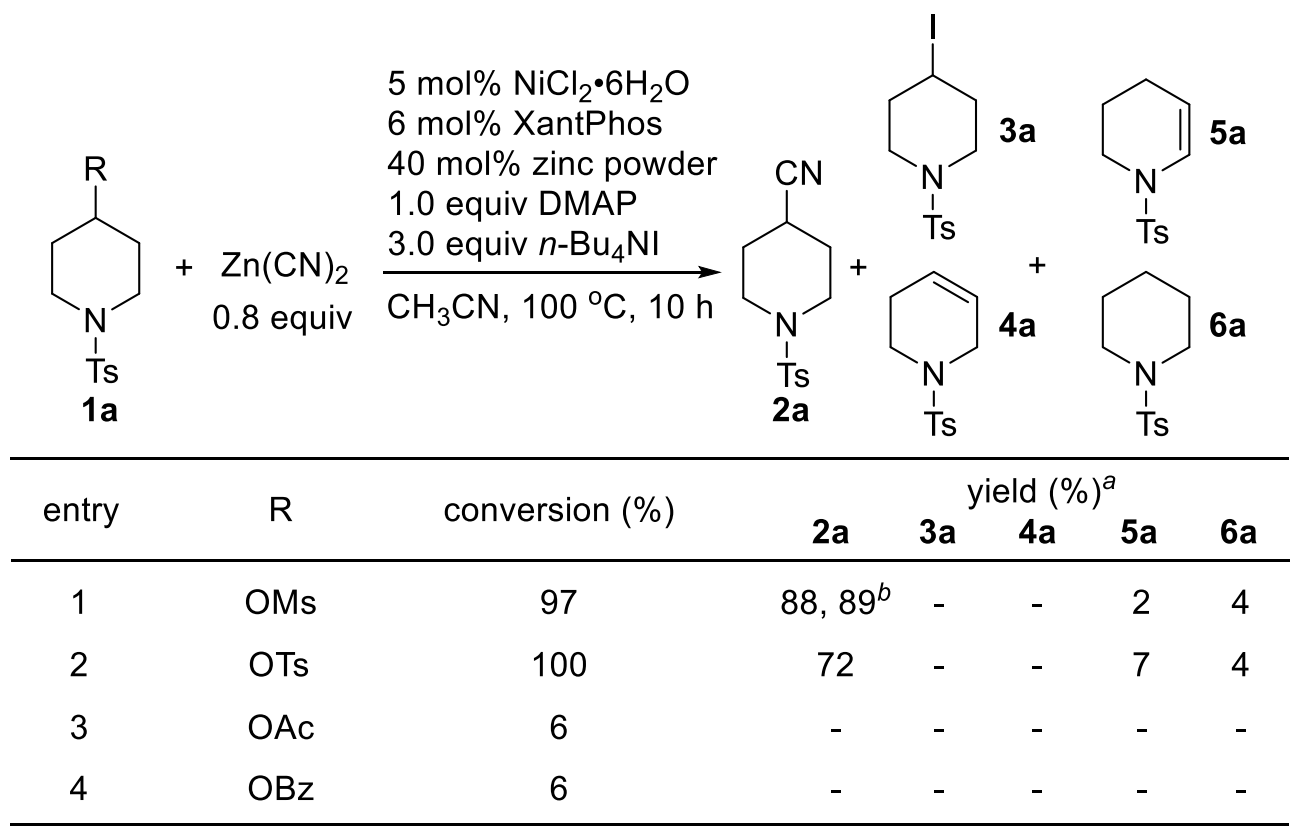

${ }^{a}$ Yields were determined by ${ }^{1} \mathrm{H}$ NMR using 1,3,5-trimethoxybenzene as an internal standard. ${ }^{b}$ Isolated yield. 


\section{Nickel-catalyzed cyanation of secondary alkyl mesylates}

Typical procedure for nickel-catalyzed cyanation of $\mathbf{1 a}$

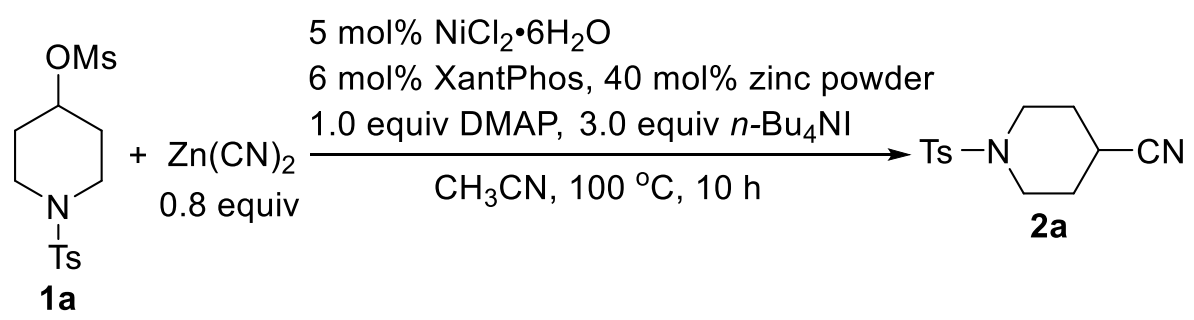

In a nitrogen-filled glove box, $\mathrm{NiCl}_{2} \cdot 6 \mathrm{H}_{2} \mathrm{O}(4.8 \mathrm{mg}, 0.02 \mathrm{mmol})$, DMAP (48.9 mg, 0.4 $\mathrm{mmol}), \mathrm{Zn}(\mathrm{CN})_{2}(37.6 \mathrm{mg}, 0.32 \mathrm{mmol})$, zinc powder (10.5 mg, $\left.0.16 \mathrm{mmol}\right), n-\mathrm{Bu} 4 \mathrm{NI}(443.2$ mg, $1.2 \mathrm{mmol})$, XantPhos (13.9 mg, $0.024 \mathrm{mmol}), \mathbf{1 a}(133.4 \mathrm{mg}, 0.4 \mathrm{mmol})$ and $\mathrm{CH}_{3} \mathrm{CN}(2.0$ $\mathrm{mL}$ ) were added sequentially to a $4 \mathrm{~mL}$ screw-cap vial (If the secondary alkyl mesylates is a liquid, it was added after $\mathrm{CH}_{3} \mathrm{CN}$ ). The vial cap was then securely fitted and taken outside the glove box. After the reaction mixture was stirred at $100{ }^{\circ} \mathrm{C}$ (oil bath) for $10 \mathrm{~h}$, the mixture was filtered through a pad of silica gel and washed with $\mathrm{CH}_{2} \mathrm{Cl}_{2}$. The solvent was evaporated under the reduced pressure and the yield were determined by ${ }^{1} \mathrm{H}$ NMR using 1,3,5-trimethoxybenzene (67.3 $\mathrm{mg}, 0.4 \mathrm{mmol})$ as an internal standard. The NMR yield of $\mathbf{2 a}$ was $88 \%$. The residue was purified by column chromatography on silica gel (eluent: petroleum ether: ethyl acetate $=20: 1$ to 2:1) to afford 1-tosylpiperidine-4-carbonitrile (2a) in $89 \%$ yield (94.0 $\mathrm{mg}$ ) as a white solid. ${ }^{1} \mathrm{H}$ NMR (400 MHz, $\left.\mathrm{CDCl}_{3}\right) 7.63(\mathrm{~d}, J=8.4 \mathrm{~Hz}, 2 \mathrm{H}), 7.34$ (d, $\left.J=8.0 \mathrm{~Hz}, 2 \mathrm{H}\right), 3.16-3.05$ (m, $4 \mathrm{H}), 2.75-2.70(\mathrm{~m}, 1 \mathrm{H}), 2.44$ (s, 3H), 2.03-1.88 (m, 4H); $\left.{ }^{13} \mathrm{C} \mathrm{NMR} \mathrm{(100} \mathrm{MHz,} \mathrm{CDCl}_{3}\right) \delta 143.9$, $132.5,129.7,127.4,120.3,43.7,27.7,25.1,21.4$. The spectroscopic data is in agreement with that previously reported. ${ }^{9}$

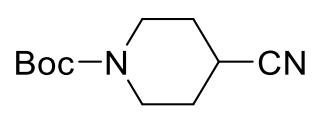

$2 \mathbf{b}$

tert-Butyl 4-cyanopiperidine-1-carboxylate (2b). $0.4 \mathrm{mmol} \mathrm{scale.} \mathrm{NiCl}_{2} \cdot 6 \mathrm{H}_{2} \mathrm{O}(4.8 \mathrm{mg}, 0.02$ mmol), DMAP (48.9 mg, $0.4 \mathrm{mmol}), \mathrm{Zn}(\mathrm{CN})_{2}(37.6 \mathrm{mg}, 0.32 \mathrm{mmol})$, zinc powder $(10.5 \mathrm{mg}$, $0.16 \mathrm{mmol}), n$-Bu $4 \mathrm{NI}(443.2 \mathrm{mg}, 1.2 \mathrm{mmol})$, XantPhos (13.9 mg, $0.024 \mathrm{mmol}), \mathbf{1 b}(111.7 \mathrm{mg}$, $0.4 \mathrm{mmol})$ and $\mathrm{CH}_{3} \mathrm{CN}(2.0 \mathrm{~mL})$ were stirred at $100{ }^{\circ} \mathrm{C}$ (oil bath) for $10 \mathrm{~h}$. The crude product was purified by column chromatography on silica gel (eluent: petroleum ether: ethyl acetate $=$ 5:1) to afford $\mathbf{2 b}$ in $90 \%$ isolated yield $\left(75.6 \mathrm{mg}\right.$ ) as a colourless oil. ${ }^{1} \mathrm{H}$ NMR (400 $\left.\mathrm{MHz}, \mathrm{CDCl}_{3}\right)$ 


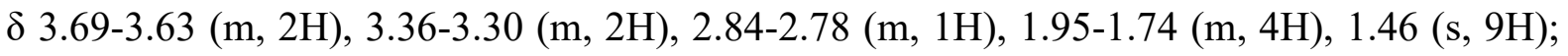
${ }^{13} \mathrm{C} \mathrm{NMR}\left(100 \mathrm{MHz}, \mathrm{CDCl}_{3}\right) \delta 154.4,121.0,80.0,41.9,28.4,28.3,26.2$. The spectroscopic data is in agreement with that previously reported. ${ }^{10}$

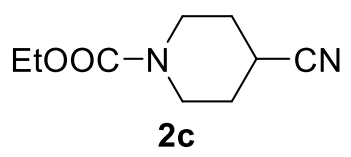

Ethyl 4-cyanopiperidine-1-carboxylate (2c). 0.4 mmol scale. $\mathrm{NiCl}_{2} \cdot 6 \mathrm{H}_{2} \mathrm{O}(4.8 \mathrm{mg}, 0.02$ mmol), DMAP (48.9 mg, $0.4 \mathrm{mmol}), \mathrm{Zn}(\mathrm{CN})_{2}(37.6 \mathrm{mg}, 0.32 \mathrm{mmol})$, zinc powder $(10.5 \mathrm{mg}$, $0.16 \mathrm{mmol}), n$-Bu $4 \mathrm{NI}(443.2 \mathrm{mg}, 1.2 \mathrm{mmol})$, XantPhos (13.9 mg, $0.024 \mathrm{mmol}), \mathbf{1 c}(100.5 \mathrm{mg}$, $0.4 \mathrm{mmol}$ ) and $\mathrm{CH}_{3} \mathrm{CN}(2.0 \mathrm{~mL})$ were stirred at $100{ }^{\circ} \mathrm{C}$ (oil bath) for $10 \mathrm{~h}$. The crude product was purified by column chromatography on silica gel (eluent: petroleum ether: ethyl acetate $=$ $3: 1)$ to afford $2 \mathrm{c}$ in $88 \%$ isolated yield $(64.0 \mathrm{mg})$ as a colourless oil. ${ }^{1} \mathrm{H} \mathrm{NMR}\left(400 \mathrm{MHz}, \mathrm{CDCl}_{3}\right)$ $\delta 4.14(\mathrm{q}, J=7.2 \mathrm{~Hz}, 2 \mathrm{H}), 3.73-3.67(\mathrm{~m}, 2 \mathrm{H}), 3.44-3.37(\mathrm{~m}, 2 \mathrm{H}), 2.87-2.81(\mathrm{~m}, 1 \mathrm{H}), 1.94-1.76$ $(\mathrm{m}, 4 \mathrm{H}), 1.26(\mathrm{t}, J=7.2 \mathrm{~Hz}, 3 \mathrm{H}) ;{ }^{13} \mathrm{C} \mathrm{NMR}\left(100 \mathrm{MHz}, \mathrm{CDCl}_{3}\right) \delta 155.0,120.8,61.4,41.6,28.2$, 26.0, 14.4. IR (neat): 2919, 2854, 2239, 1690, 1429, 1267, 1219, 1122, 1030, $768 \mathrm{~cm}^{-1}$. HRMS (EI-TOF) m/z: [M] $]^{+}$calcd for $\mathrm{C}_{9} \mathrm{H}_{14} \mathrm{~N}_{2} \mathrm{O}_{2}$ 182.1050; found 182.1051 .

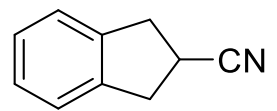

2d

2,3-Dihydro-1H-indene-2-carbonitrile (2d). 0.4 mmol scale. $\mathrm{NiCl}_{2} \cdot 6 \mathrm{H}_{2} \mathrm{O}$ (4.8 mg, 0.02 mmol), DMAP (48.9 mg, $0.4 \mathrm{mmol}), \mathrm{Zn}(\mathrm{CN})_{2}(37.6 \mathrm{mg}, 0.32 \mathrm{mmol})$, zinc powder $(10.5 \mathrm{mg}$, $0.16 \mathrm{mmol}), n$-Bu $4 \mathrm{NI}(443.2 \mathrm{mg}, 1.2 \mathrm{mmol})$, XantPhos (13.9 mg, $0.024 \mathrm{mmol}), 1 \mathrm{~d}$ (84.9 mg, $0.4 \mathrm{mmol}$ ) and $\mathrm{CH}_{3} \mathrm{CN}(2.0 \mathrm{~mL})$ were stirred at $100{ }^{\circ} \mathrm{C}$ (oil bath) for $10 \mathrm{~h}$. The crude product was purified by column chromatography on silica gel (eluent: petroleum ether: ethyl acetate $=$ 40:1 to $30: 1)$ to afford $\mathbf{2 d}$ in $77 \%$ isolated yield $\left(44.2 \mathrm{mg}\right.$ ) as a colourless oil. ${ }^{1} \mathrm{H}$ NMR (400 $\left.\mathrm{MHz}, \mathrm{CDCl}_{3}\right) \delta$ 7.24-7.19 (m, 4H), 3.38-3.23 (m, 5H); $\left.{ }^{13} \mathrm{C} \mathrm{NMR} \mathrm{(100} \mathrm{MHz,} \mathrm{CDCl}_{3}\right) \delta$ 139.6, $127.2,124.4,122.4,37.3,27.5$. The spectroscopic data is in agreement with that previously reported..$^{9}$ 
<smiles>COc1cccc2c1CCC(C#N)C2</smiles>

5-Methoxy-1,2,3,4-tetrahydronaphthalene-2-carbonitrile $\quad$ (2e). $0.4 \quad \mathrm{mmol}$ scale. $\mathrm{NiCl}_{2} \cdot 6 \mathrm{H}_{2} \mathrm{O}(4.8 \mathrm{mg}, 0.02 \mathrm{mmol}), \mathrm{DMAP}(48.9 \mathrm{mg}, 0.4 \mathrm{mmol}), \mathrm{Zn}(\mathrm{CN})_{2}(37.6 \mathrm{mg}, 0.32 \mathrm{mmol})$, zinc powder (10.5 mg, $0.16 \mathrm{mmol}), n$-Bu $4 \mathrm{NI}$ (443.2 mg, $1.2 \mathrm{mmol}$ ), XantPhos (13.9 mg, 0.024 mmol), 1e (102.5 mg, $0.4 \mathrm{mmol})$ and $\mathrm{CH}_{3} \mathrm{CN}(2.0 \mathrm{~mL})$ were stirred at $100{ }^{\circ} \mathrm{C}$ (oil bath) for 10 h. The crude product was purified by column chromatography on silica gel (eluent: petroleum ether: ethyl acetate $=30: 1)$ to afford $2 \mathrm{e}$ in $62 \%$ isolated yield $(46.4 \mathrm{mg})$ as white solid. ${ }^{1} \mathrm{H}$ NMR $\left(400 \mathrm{MHz}, \mathrm{CDCl}_{3}\right) \delta 7.12(\mathrm{t}, J=8.0 \mathrm{~Hz}, 1 \mathrm{H}), 6.69(\mathrm{~d}, J=8.4 \mathrm{~Hz}, 2 \mathrm{H}), 3.81(\mathrm{~s}, 3 \mathrm{H}), 3.12-2.99$ $(\mathrm{m}, 2 \mathrm{H}), 2.94-2.87(\mathrm{~m}, 2 \mathrm{H}), 2.69-2.61(\mathrm{~m}, 1 \mathrm{H}), 2.22-2.15(\mathrm{~m}, 1 \mathrm{H}), 2.05-1.96(\mathrm{~m}, 1 \mathrm{H}) ;{ }^{13} \mathrm{C}$ NMR (100 MHz, $\left.\mathrm{CDCl}_{3}\right) \delta 157.1,133.5,126.6,123.5,122.1,120.8,107.7,55.2,32.4,25.9$, 25.1, 21.2. The spectroscopic data is in agreement with that previously reported. ${ }^{9}$

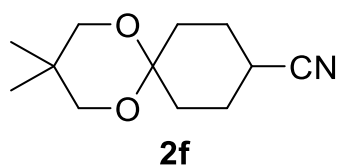

3,3-Dimethyl-1,5-dioxaspiro[5.5] undecane-9-carbonitrile (2f). $0.4 \mathrm{mmol} \mathrm{scale.} \mathrm{NiCl}_{2} \cdot 6 \mathrm{H}_{2} \mathrm{O}$ (4.8 mg, $0.02 \mathrm{mmol})$, DMAP (48.9 mg, $0.4 \mathrm{mmol}), \mathrm{Zn}(\mathrm{CN})_{2}(37.6 \mathrm{mg}, 0.32 \mathrm{mmol})$, zinc powder (10.5 mg, $0.16 \mathrm{mmol}), n$-Bu $4 \mathrm{NI}$ (443.2 mg, $1.2 \mathrm{mmol}$ ), XantPhos (13.9 mg, 0.024 mmol), 1 f (111.3 mg, $0.4 \mathrm{mmol})$ and $\mathrm{CH}_{3} \mathrm{CN}(2.0 \mathrm{~mL})$ were stirred at $100{ }^{\circ} \mathrm{C}$ (oil bath) for 10 h. The crude product was purified by column chromatography on silica gel (eluent: petroleum ether: ethyl acetate $=10: 1$ to $5: 1)$ to afford $\mathbf{2 f}$ in $82 \%$ isolated yield $(68.5 \mathrm{mg})$ as a white solid. M.p. $62-64{ }^{\circ} \mathrm{C} .{ }^{1} \mathrm{H}$ NMR (400 MHz, $\left.\mathrm{CDCl}_{3}\right) \delta 3.50$ (s, 2H), 3.47 (s, 2H), 2.68-2.62 (m, 1H), 2.04-1.99 (m, 2H), 1.94-1.74 (m, 6H), 0.96 (s, 6H); $\left.{ }^{13} \mathrm{C} \mathrm{NMR} \mathrm{(100} \mathrm{MHz,} \mathrm{CDCl}_{3}\right) \delta 121.8,95.8$, 69.9, 69.7, 30.0, 29.9, 27.0, 25.4, 22.5. IR (neat): 2954, 2867, 2233, 1440, 1391, 1241, 1104, 910, $901 \mathrm{~cm}^{-1}$. HRMS (EI-TOF) m/z: [M] calcd for $\mathrm{C}_{12} \mathrm{H}_{19} \mathrm{NO}_{2} 209.1410$; found 209.1405. 
<smiles>N#CC1CCCCCCCCCCC1</smiles>

2g

Cyclododecanecarbonitrile (2g). $0.4 \mathrm{mmol}$ scale. $\mathrm{NiCl}_{2} \cdot 6 \mathrm{H}_{2} \mathrm{O}$ (4.8 mg, $\left.0.02 \mathrm{mmol}\right)$, DMAP (48.9 mg, $0.4 \mathrm{mmol}), \mathrm{Zn}(\mathrm{CN})_{2}(37.6 \mathrm{mg}, 0.32 \mathrm{mmol})$, zinc powder (10.5 mg, $\left.0.16 \mathrm{mmol}\right), n$ $\mathrm{Bu}_{4} \mathrm{NI}$ (443.2 mg, $\left.1.2 \mathrm{mmol}\right)$, XantPhos (13.9 mg, $\left.0.024 \mathrm{mmol}\right), 1 \mathrm{~g}(105.0 \mathrm{mg}, 0.4 \mathrm{mmol})$ and $\mathrm{CH}_{3} \mathrm{CN}\left(2.0 \mathrm{~mL}\right.$ ) were stirred at $100{ }^{\circ} \mathrm{C}$ (oil bath) for $10 \mathrm{~h}$. The crude product was purified by column chromatography on silica gel (eluent: petroleum ether: dichloromethane $=3: 1$ ) to afford $2 \mathrm{~g}$ in $24 \%$ isolated yield $(18.4 \mathrm{mg})$ as a colourless oil. ${ }^{1} \mathrm{H} \mathrm{NMR}\left(400 \mathrm{MHz}, \mathrm{CDCl}_{3}\right) \delta$ 2.67-2.61 (m, 1H), 1.79-1.61 (m, 4H), 1.59-1.33 (m, 18H); $\left.{ }^{13} \mathrm{C} \mathrm{NMR} \mathrm{(100} \mathrm{MHz,} \mathrm{CDCl}_{3}\right) \delta$ $123.2,27.1,26.4,23.6,23.4,23.2,23.1,21.8$. The spectroscopic data is in agreement with that previously reported. ${ }^{9}$

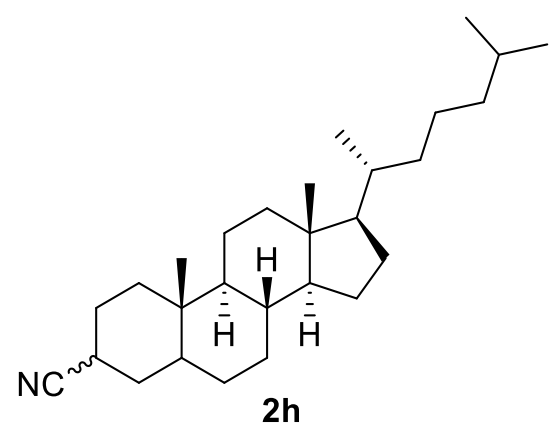

$(8 R, 9 S, 10 S, 13 R, 14 S, 17 R)-10,13-D i m e t h y l-17-((R)-6-m e t h y l h e p t a n-2-y l) h e x a d e c a h y d r o-$ 1H-cyclopenta[a]phenanthrene-3-carbonitrile (2h). 0.4 mmol scale. $\mathrm{NiCl}_{2} \cdot 6 \mathrm{H}_{2} \mathrm{O}(4.8 \mathrm{mg}$, $0.02 \mathrm{mmol})$, DMAP (48.9 mg, $0.4 \mathrm{mmol}), \mathrm{Zn}(\mathrm{CN})_{2}(37.6 \mathrm{mg}, 0.32 \mathrm{mmol})$, zinc powder (10.5 mg, $0.16 \mathrm{mmol}), n$-Bu $4 \mathrm{NI}$ (443.2 mg, $1.2 \mathrm{mmol})$, XantPhos (13.9 mg, $0.024 \mathrm{mmol}), \mathbf{1 h}$ (186.7 $\mathrm{mg}, 0.4 \mathrm{mmol}$ ) and $\mathrm{CH}_{3} \mathrm{CN}\left(2.0 \mathrm{~mL}\right.$ ) were stirred at $100{ }^{\circ} \mathrm{C}$ (oil bath) for $10 \mathrm{~h}$. The solvent was evaporated under the reduced pressure and the crude product was purified by column chromatography on silica gel (eluent: petroleum ether: dichloromethane $=5: 1$ ) to afford a mixture of two diastereoisomers in 33\% yield (52.2 mg, isomer A) and 44\% yield (69.4 mg, isomer B) as white solids, respectively. For isomer A: M.p. 166-168 ${ }^{\circ} \mathrm{C} .{ }^{1} \mathrm{H}$ NMR $(400 \mathrm{MHz}$, $\left.\mathrm{CDCl}_{3}\right) \delta 2.95(\mathrm{~s}, 1 \mathrm{H}), 1.99-1.95(\mathrm{~m}, 1 \mathrm{H}), 1.87-1.47(\mathrm{~m}, 11 \mathrm{H}), 1.38-0.85(\mathrm{~m}, 26 \mathrm{H}), 0.83-0.76$ $(\mathrm{m}, 4 \mathrm{H}), 0.65(\mathrm{~s}, 3 \mathrm{H}) ;{ }^{13} \mathrm{C} \mathrm{NMR}\left(100 \mathrm{MHz}, \mathrm{CDCl}_{3}\right) \delta 122.7,56.3,56.1,53.8,42.5,42.3,39.8$, 
$39.5,36.1,35.9,35.8,35.3,34.3,31.6,30.4,28.2,28.1,28.0,27.5,24.2,24.1,23.8,22.8,22.5$, 20.7, 18.6, 12.0, 11.8. IR (neat): 2931, 2866, 2847, 2239, 1469, 1443, 1380, 906, $736 \mathrm{~cm}^{-1}$. HRMS (EI-TOF) m/z: [M] $]^{+}$calcd for $\mathrm{C}_{28} \mathrm{H}_{47} \mathrm{~N}$ 397.3703; found 397.3710. For isomer B: M.p. 141-143 ${ }^{\circ} \mathrm{C} .{ }^{1} \mathrm{H}$ NMR (400 MHz, $\mathrm{CDCl}_{3}$ ) $\delta$ 2.46-2.37 (m, 1H), 1.98-1.90 (m, 2H), 1.85-0.85 $(\mathrm{m}, 37 \mathrm{H}), 0.81(\mathrm{~s}, 3 \mathrm{H}), 0.67-0.60(\mathrm{~m}, 4 \mathrm{H}) ;{ }^{13} \mathrm{C} \mathrm{NMR}\left(100 \mathrm{MHz}, \mathrm{CDCl}_{3}\right) \delta 122.8,56.3,56.2$, 54.0, 45.7, 42.5, 39.8, 39.4, 37.2, 36.1, 35.7, 35.4, 35.3, 31.8, 31.7, 28.4, 28.2, 28.1, 27.9, 25.6, 24.1, 23.8, 22.8, 22.5, 20.8, 18.6, 12.0, 12.0. IR (neat): 2928, 2865, 2236, 1465, 1383, 907, 733. HRMS (EI-TOF) m/z: [M] $]^{+}$calcd for $\mathrm{C}_{28} \mathrm{H}_{47} \mathrm{~N}$ 397.3703; found 397.3710.<smiles>COc1ccc(CCC(C)C#N)cc1</smiles>

4-(4-Methoxyphenyl)-2-methylbutanenitrile (2i). $0.4 \mathrm{mmol} \mathrm{scale.} \mathrm{NiCl}_{2} \cdot 6 \mathrm{H}_{2} \mathrm{O}(4.8 \mathrm{mg}, 0.02$ mmol), DMAP (48.9 mg, $0.4 \mathrm{mmol}), \mathrm{Zn}(\mathrm{CN})_{2}(37.6 \mathrm{mg}, 0.32 \mathrm{mmol})$, zinc powder $(10.5 \mathrm{mg}$, $0.16 \mathrm{mmol}), n$-Bu $4 \mathrm{NI}$ (443.2 mg, $1.2 \mathrm{mmol}$ ), XantPhos (13.9 mg, $0.024 \mathrm{mmol}), \mathrm{CH}_{3} \mathrm{CN}$ (2.0 $\mathrm{mL}$ ) and $1 \mathbf{i}(103.3 \mathrm{mg}, 0.4 \mathrm{mmol})$ were stirred at $100{ }^{\circ} \mathrm{C}$ (oil bath) for $10 \mathrm{~h}$. The crude product was purified by column chromatography on silica gel (eluent: petroleum ether: ethyl acetate = $50: 1$ to $20: 1)$ to afford $2 \mathbf{i}$ in $71 \%$ isolated yield $\left(54.0 \mathrm{mg}\right.$ ) as a colourless oil. ${ }^{1} \mathrm{H}$ NMR (400 $\left.\mathrm{MHz}, \mathrm{CDCl}_{3}\right) \delta 7.11(\mathrm{~d}, J=8.4 \mathrm{~Hz}, 2 \mathrm{H}), 6.84(\mathrm{~d}, J=8.4 \mathrm{~Hz}, 2 \mathrm{H}), 3.78$ (s, 3H), 2.84-2.77 (m, 1H), 2.72-2.64 (m, 1H), 2.60-2.51 (m, 1H), 1.96-1.87 (m, 1H), 1.83-1.74 (m, 1H), $1.31(\mathrm{~d}, J=$ $7.2 \mathrm{~Hz}, 3 \mathrm{H}) ;{ }^{13} \mathrm{C} \mathrm{NMR}\left(100 \mathrm{MHz}, \mathrm{CDCl}_{3}\right) \delta 158.0,132.0,129.2,122.7,113.9,55.1,35.8,32.1$, 24.6, 17.9. The spectroscopic data is in agreement with that previously reported. ${ }^{9}$<smiles>CCCC(C#N)CCc1ccccc1</smiles>

2j

2-Phenethylpentanenitrile (2j). $0.4 \mathrm{mmol} \mathrm{scale} . \mathrm{NiCl}_{2} \cdot 6 \mathrm{H}_{2} \mathrm{O}$ (4.8 mg, $\left.0.02 \mathrm{mmol}\right)$, DMAP (48.9 mg, $0.4 \mathrm{mmol}), \mathrm{Zn}(\mathrm{CN})_{2}(37.6 \mathrm{mg}, 0.32 \mathrm{mmol})$, zinc powder (10.5 mg, $\left.0.16 \mathrm{mmol}\right), n$ Bu 4 NI (443.2 mg, $1.2 \mathrm{mmol})$, XantPhos (13.9 mg, $0.024 \mathrm{mmol}), \mathbf{1 j}$ (102.5 mg, $0.4 \mathrm{mmol}$ ) and 
$\mathrm{CH}_{3} \mathrm{CN}\left(2.0 \mathrm{~mL}\right.$ ) were stirred at $100{ }^{\circ} \mathrm{C}$ (oil bath) for $10 \mathrm{~h}$. The crude product was purified by column chromatography on silica gel (eluent: petroleum ether: dichloromethane $=3: 1$ ) to afford $2 \mathbf{j}$ in $58 \%$ isolated yield $(43.1 \mathrm{mg})$ as a colourless oil. ${ }^{1} \mathrm{H}$ NMR $\left(400 \mathrm{MHz}, \mathrm{CDCl}_{3}\right) \delta$ 7.32-7.28 (m, 2H), 7.24-7.19 (m, 3H), 2.92-2.85 (m, 1H), 2.77-2.69 (m, 1H), 2.53-2.46 (m, 1H), 1.98-1.79 (m, 2H), 1.68-1.37 (m, 4H), 0.93 (t, $J=7.2 \mathrm{~Hz}, 3 \mathrm{H}) ;{ }^{13} \mathrm{C}$ NMR (100 MHz, $\left.\mathrm{CDCl}_{3}\right) \delta 140.2,128.5,128.3,126.3,122.0,34.2,33.9,33.2,30.7,20.3,13.5$. The spectroscopic data is in agreement with that previously reported. ${ }^{11}$<smiles>N#CC(Cc1ccccc1)Cc1ccccc1</smiles>

2k

2-Benzyl-3-phenylpropanenitrile (2k). $0.4 \mathrm{mmol} \mathrm{scale} . \mathrm{NiCl}_{2} \cdot 6 \mathrm{H}_{2} \mathrm{O}(4.8 \mathrm{mg}, 0.02 \mathrm{mmol})$, DMAP (48.9 mg, $0.4 \mathrm{mmol}), \mathrm{Zn}(\mathrm{CN})_{2}(37.6 \mathrm{mg}, 0.32 \mathrm{mmol})$, zinc powder (10.5 mg, 0.16 mmol), $n$-Bu $\mathrm{Bu}_{4}$ (443.2 mg, $\left.1.2 \mathrm{mmol}\right)$, XantPhos (13.9 mg, $\left.0.024 \mathrm{mmol}\right), 1 \mathrm{k}$ (116.2 mg, 0.4 mmol) and $\mathrm{CH}_{3} \mathrm{CN}\left(2.0 \mathrm{~mL}\right.$ ) were stirred at $100{ }^{\circ} \mathrm{C}$ (oil bath) for $10 \mathrm{~h}$. The crude product was purified by column chromatography on silica gel (eluent: petroleum ether: ethyl acetate $=40: 1$ to $10: 1)$ to afford $\mathbf{2 k}$ in $71 \%$ isolated yield $(63.2 \mathrm{mg})$ as a white solid. ${ }^{1} \mathrm{H}$ NMR (400 MHz, $\left.\mathrm{CDCl}_{3}\right) \delta$ 7.35-7.22 (m, 10H), 3.04-2.97 (m, 1H), $2.89(\mathrm{~d}, J=6.8 \mathrm{~Hz}, 4 \mathrm{H}) ;{ }^{13} \mathrm{C} \mathrm{NMR}(100$ $\left.\mathrm{MHz}, \mathrm{CDCl}_{3}\right) \delta 136.7,129.0,128.7,127.2,121.2,37.8,35.8$. The spectroscopic data is in agreement with that previously reported. ${ }^{9}$<smiles>CC(C#N)Cc1cccc(C(F)(F)F)c1</smiles>

2-Methyl-3-(3-(trifluoromethyl)phenyl)propanenitrile (2l). $0.4 \mathrm{mmol}$ scale. $\mathrm{NiCl}_{2} \cdot 6 \mathrm{H}_{2} \mathrm{O}$ (4.8 mg, $0.02 \mathrm{mmol})$, DMAP (48.9 mg, $0.4 \mathrm{mmol}), \mathrm{Zn}(\mathrm{CN})_{2}(37.6 \mathrm{mg}, 0.32 \mathrm{mmol})$, zinc powder (10.5 mg, $0.16 \mathrm{mmol}), n$-Bu 4 NI (443.2 mg, $1.2 \mathrm{mmol}$ ), XantPhos (13.9 mg, 0.024 mmol), 11 (112.9 mg, $0.4 \mathrm{mmol})$ and $\mathrm{CH}_{3} \mathrm{CN}(2.0 \mathrm{~mL})$ were stirred at $100{ }^{\circ} \mathrm{C}$ (oil bath) for 10 h. The crude product was purified by column chromatography on silica gel (eluent: petroleum ether: dichloromethane $=3: 1)$ to afford $\mathbf{2 l}$ in $81 \%$ isolated yield $(69.1 \mathrm{mg})$ as a colourless oil. ${ }^{1} \mathrm{H}$ NMR (400 MHz, $\left.\mathrm{CDCl}_{3}\right) \delta$ 7.56-7.54 (m, 1H), 7.49-7.46 (m, 3H), 3.01-2.84 (m, 3H), 1.35 
$(\mathrm{d}, J=6.4 \mathrm{~Hz}, 3 \mathrm{H}) ;{ }^{13} \mathrm{C} \mathrm{NMR}\left(100 \mathrm{MHz}, \mathrm{CDCl}_{3}\right) \delta 137.7,132.4,131.0\left(\mathrm{q},{ }^{2} J_{\mathrm{C}-\mathrm{F}}=32.3 \mathrm{~Hz}\right)$, $129.2,125.7\left(\mathrm{q},{ }^{3} J_{\mathrm{C}-\mathrm{F}}=3.6 \mathrm{~Hz}\right), 124.1\left(\mathrm{q},{ }^{3} J_{\mathrm{C}-\mathrm{F}}=3.6 \mathrm{~Hz}\right), 123.9\left(\mathrm{q},{ }^{1} J_{\mathrm{C}-\mathrm{F}}=270.9 \mathrm{~Hz}\right), 121.9$, 39.6, 27.3, 17.5. IR (neat): 2241, 1451, 1325, 1202, 1163, 1119, 1098, 1073, 806, 793, 702, 663. HRMS (EI-TOF) m/z: [M] $]^{+}$calcd for $\mathrm{C}_{11} \mathrm{H}_{10} \mathrm{~F}_{3} \mathrm{~N} 213.0760$; found 213.0762.<smiles>[3H]c1ccc(/C=C/C)cc1</smiles>

(E)-4-(Prop-1-en-1-yl)benzonitrile (7). $0.4 \mathrm{mmol}$ scale. $\mathrm{NiCl}_{2} \cdot 6 \mathrm{H}_{2} \mathrm{O}(4.8 \mathrm{mg}, 0.02 \mathrm{mmol}$ ), DMAP (48.9 mg, $0.4 \mathrm{mmol}), \mathrm{Zn}(\mathrm{CN})_{2}(37.6 \mathrm{mg}, 0.32 \mathrm{mmol})$, zinc powder (10.5 mg, 0.16 mmol), $n$-Bu4NI (443.2 mg, $1.2 \mathrm{mmol})$, XantPhos (13.9 mg, $0.024 \mathrm{mmol}), 1 \mathrm{~m}$ (117.3 mg, 0.4 mmol) and $\mathrm{CH}_{3} \mathrm{CN}\left(2.0 \mathrm{~mL}\right.$ ) were stirred at $100{ }^{\circ} \mathrm{C}$ (oil bath) for $10 \mathrm{~h}$. The crude product was purified by column chromatography on silica gel (eluent: petroleum ether: dichloromethane $=$ $3: 1)$ to afford $2 \mathrm{l}$ in $31 \%$ isolated yield $(17.5 \mathrm{mg})$ as a colourless oil. ${ }^{1} \mathrm{H} \mathrm{NMR}\left(400 \mathrm{MHz}, \mathrm{CDCl}_{3}\right)$ $\delta 7.56(\mathrm{~d}, J=8.0 \mathrm{~Hz}, 2 \mathrm{H}), 7.39$ (d, $J=8.0 \mathrm{~Hz}, 2 \mathrm{H}), 6.44-6.34(\mathrm{~m}, 2 \mathrm{H}), 1.92$ (d, $J=4.4 \mathrm{~Hz}$, $3 \mathrm{H}) ;{ }^{13} \mathrm{C}$ NMR (100 MHz, $\left.\mathrm{CDCl}_{3}\right) \delta 142.3,132.3,130.1,129.7,126.2,119.1,109.9,18.6$. The spectroscopic data is in agreement with that previously reported. ${ }^{12}$<smiles>CC(C#N)CC[OH+]</smiles>

2n

4-((tert-Butyldimethylsilyl)oxy)-2-methylbutanenitrile (2n). $0.4 \mathrm{mmol} \mathrm{scale.} \mathrm{NiCl}_{2} \cdot 6 \mathrm{H}_{2} \mathrm{O}$ (4.8 mg, $0.02 \mathrm{mmol})$, DMAP (48.9 mg, $0.4 \mathrm{mmol}), \mathrm{Zn}(\mathrm{CN})_{2}(37.6 \mathrm{mg}, 0.32 \mathrm{mmol})$, zinc powder (10.5 mg, $0.16 \mathrm{mmol}), n$-Bu $4 \mathrm{NI}$ (443.2 mg, $1.2 \mathrm{mmol}$ ), XantPhos (13.9 mg, 0.024 $\mathrm{mmol}), \mathrm{CH}_{3} \mathrm{CN}(2.0 \mathrm{~mL})$ and $\mathbf{1 n}(113.0 \mathrm{mg}, 0.4 \mathrm{mmol})$ were stirred at $100{ }^{\circ} \mathrm{C}$ (oil bath) for 10 h. The crude product was purified by column chromatography on silica gel (eluent: petroleum ether: dichloromethane $=2: 1)$ to afford $\mathbf{2 n}$ in $68 \%$ isolated yield $(58.4 \mathrm{mg})$ as a light yellow oil . ${ }^{1} \mathrm{H}$ NMR (400 MHz, $\left.\mathrm{CDCl}_{3}\right) \delta 3.76(\mathrm{t}, J=6.4 \mathrm{~Hz}, 2 \mathrm{H}), 2.92-2.83(\mathrm{~m}, 1 \mathrm{H}), 1.86-1.69(\mathrm{~m}, 2 \mathrm{H})$, $1.34(\mathrm{~d}, J=7.2 \mathrm{~Hz}, 3 \mathrm{H}), 0.90$ (s, 9H), 0.08 (s, 3H), 0.07 (s, 3H); $\left.{ }^{13} \mathrm{C} \mathrm{NMR} \mathrm{(100} \mathrm{MHz,} \mathrm{CDCl}_{3}\right)$ $\delta 122.9,59.6,36.8,25.8,21.8,18.2,17.7,-5.6$. IR (neat): 2953, 2930, 2856, 2239, 1461, 1255 , 
1096, 828, 811, $776 \mathrm{~cm}^{-1}$. HRMS (ESI-TOF) m/z: $[\mathrm{M}+\mathrm{H}]^{+}$calcd for $\mathrm{C}_{11} \mathrm{H}_{24} \mathrm{NOSi} 214.1622$; found 214.1625 .<smiles>CC(C#N)CCOCc1ccc(F)cc1</smiles>

4-((4-Fluorobenzyl)oxy)-2-methylbutanenitrile (2o). $0.4 \mathrm{mmol} \mathrm{scale.} \mathrm{NiCl}_{2} \cdot 6 \mathrm{H}_{2} \mathrm{O}(4.8 \mathrm{mg}$, $0.02 \mathrm{mmol})$, DMAP (48.9 mg, $0.4 \mathrm{mmol}), \mathrm{Zn}(\mathrm{CN})_{2}(37.6 \mathrm{mg}, 0.32 \mathrm{mmol})$, zinc powder (10.5 mg, $0.16 \mathrm{mmol}$ ), $n$-Bu4NI (443.2 mg, $1.2 \mathrm{mmol}$ ), XantPhos (13.9 mg, $0.024 \mathrm{mmol}), \mathrm{CH}_{3} \mathrm{CN}$ $(2.0 \mathrm{~mL})$ and $10(110.5 \mathrm{mg}, 0.4 \mathrm{mmol})$ were stirred at $100{ }^{\circ} \mathrm{C}$ (oil bath) for $10 \mathrm{~h}$. The crude product was purified by column chromatography on silica gel (eluent: petroleum ether: ethyl acetate $=10: 1)$ to afford 20 in $70 \%$ isolated yield $(58.1 \mathrm{mg})$ as a colourless oil. ${ }^{1} \mathrm{H}$ NMR (400 $\left.\mathrm{MHz}, \mathrm{CDCl}_{3}\right) \delta$ 7.32-7.28 (m, 2H), 7.06-7.01 (m, 2H), $4.48(\mathrm{dd}, J=15.6 \mathrm{~Hz}, 7.6 \mathrm{~Hz}, 2 \mathrm{H}), 3.61$ $(\mathrm{t}, J=6.4 \mathrm{~Hz}, 2 \mathrm{H}), 2.93-2.84(\mathrm{~m}, 1 \mathrm{H}), 1.92-1.80(\mathrm{~m}, 2 \mathrm{H}), 1.33(\mathrm{~d}, J=7.2 \mathrm{~Hz}, 3 \mathrm{H}) ;{ }^{13} \mathrm{C} \mathrm{NMR}$ $\left(100 \mathrm{MHz}, \mathrm{CDCl}_{3}\right) \delta 162.3\left(\mathrm{~d},{ }^{1} J_{\mathrm{C}-\mathrm{F}}=244.4 \mathrm{~Hz}\right), 133.6\left(\mathrm{~d},{ }^{4} J_{\mathrm{C}-\mathrm{F}}=2.9 \mathrm{~Hz}\right), 129.4\left(\mathrm{~d},{ }^{3} J_{\mathrm{C}-\mathrm{F}}=8.2\right.$ $\mathrm{Hz}), 122.6,115.2\left(\mathrm{~d},{ }^{2} J_{\mathrm{C}-\mathrm{F}}=21.4 \mathrm{~Hz}\right), 72.5,66.8,34.1,22.4,17.8$. The spectroscopic data is in agreement with that previously reported. ${ }^{9}$<smiles>CCC(C#N)CCc1cn(C)c2ccccc12</smiles>

2-Ethyl-4-(1-methyl-1H-indol-3-yl)butanenitrile (2p). 0.4 mmol scale. $\mathrm{NiCl}_{2} \cdot 6 \mathrm{H}_{2} \mathrm{O}(4.8 \mathrm{mg}$, $0.02 \mathrm{mmol})$, DMAP (48.9 mg, $0.4 \mathrm{mmol}), \mathrm{Zn}(\mathrm{CN})_{2}(37.6 \mathrm{mg}, 0.32 \mathrm{mmol})$, zinc powder (10.5 mg, $0.16 \mathrm{mmol}$ ), $n$-Bu4NI (443.2 mg, $1.2 \mathrm{mmol}$ ), XantPhos (13.9 mg, $0.024 \mathrm{mmol}), 1 p(118.2$ $\mathrm{mg}, 0.4 \mathrm{mmol}$ ) and $\mathrm{CH}_{3} \mathrm{CN}\left(2.0 \mathrm{~mL}\right.$ ) were stirred at $100{ }^{\circ} \mathrm{C}$ (oil bath) for $10 \mathrm{~h}$. The crude product was purified by column chromatography on silica gel (eluent: petroleum ether: ethyl acetate $=10: 1)$ to afford $\mathbf{2 p}$ in $27 \%$ isolated yield $(24.7 \mathrm{mg})$ as a yellow oil. ${ }^{1} \mathrm{H}$ NMR (400 $\left.\mathrm{MHz}, \mathrm{CDCl}_{3}\right) \delta 7.58(\mathrm{~d}, J=8.0 \mathrm{~Hz}, 1 \mathrm{H}), 7.30(\mathrm{~d}, J=8.4 \mathrm{~Hz}, 1 \mathrm{H}), 7.23(\mathrm{t}, J=8.0 \mathrm{~Hz}, 1 \mathrm{H})$, 
$7.11(\mathrm{t}, J=7.6 \mathrm{~Hz}, 1 \mathrm{H}), 6.89(\mathrm{~s}, 1 \mathrm{H}), 3.74(\mathrm{~s}, 3 \mathrm{H}), 3.07-3.00(\mathrm{~m}, 1 \mathrm{H}), 2.93-2.85(\mathrm{~m}, 1 \mathrm{H}), 2.51-$ $2.44(\mathrm{~m}, 1 \mathrm{H}), 2.02-1.90(\mathrm{~m}, 2 \mathrm{H}), 1.68-1.57(\mathrm{~m}, 2 \mathrm{H}), 1.05(\mathrm{t}, J=7.2 \mathrm{~Hz}, 3 \mathrm{H}) ;{ }^{13} \mathrm{C} \mathrm{NMR}(100$ $\left.\mathrm{MHz}, \mathrm{CDCl}_{3}\right) \delta 137.1,127.4,126.6,122.2,121.6,118.8,118.7,112.7,109.3,32.6,32.5,25.4$, 22.6, 11.5. IR (neat): 2931, 2231, 1613, 1472, 1377, 1326, 1247, 1012, $737 \mathrm{~cm}^{-1}$. HRMS (ESITOF) m/z: [M+H $]^{+}$calcd for $\mathrm{C}_{15} \mathrm{H}_{19} \mathrm{~N}_{2} 227.1543$; found 227.1540 .

When the reaction was performed at $80^{\circ} \mathrm{C}$ (oil bath) for $24 \mathrm{~h}, \mathbf{2 p}$ could be afforded in $53 \%$ isolated yield $(47.7 \mathrm{mg})$ as a yellow oil.<smiles>CCC(C#N)CCN(C)c1ccccc1</smiles>

2-Ethyl-4-(methyl(phenyl)amino)butanenitrile (2q). $0.4 \mathrm{mmol}$ scale. $\mathrm{NiCl}_{2} \cdot 6 \mathrm{H}_{2} \mathrm{O}(4.8 \mathrm{mg}$, $0.02 \mathrm{mmol})$, DMAP (48.9 mg, $0.4 \mathrm{mmol}), \mathrm{Zn}(\mathrm{CN})_{2}(37.6 \mathrm{mg}, 0.32 \mathrm{mmol})$, zinc powder (10.5 mg, $0.16 \mathrm{mmol}$ ), $n$-Bu4NI (443.2 mg, $1.2 \mathrm{mmol}$ ), XantPhos (13.9 mg, $0.024 \mathrm{mmol}), 1 \mathrm{q}$ (108.6 $\mathrm{mg}, 0.4 \mathrm{mmol}$ ) and $\mathrm{CH}_{3} \mathrm{CN}\left(2.0 \mathrm{~mL}\right.$ ) were stirred at $80^{\circ} \mathrm{C}$ (oil bath) for $24 \mathrm{~h}$. The crude product was purified by column chromatography on silica gel (eluent: petroleum ether: ethyl acetate = $30: 1)$ to afford $\mathbf{2 q}$ in $31 \%$ isolated yield $(24.9 \mathrm{mg})$ as a colourless oil. ${ }^{1} \mathrm{H}$ NMR (400 MHz, $\left.\mathrm{CDCl}_{3}\right) \delta$ 7.27-7.23 (m, 2H), 6.74-6.72 (m, 3H), 3.59-3.42 (m, 2H), 2.95 (s, 3H), 2.56-2.49 (m, 1H), 1.92-1.79 (m, 2H), 1.69-1.60 (m, 2H), 1.09 (t, $J=7.6 \mathrm{~Hz}, 3 \mathrm{H}) ;{ }^{13} \mathrm{C}$ NMR (100 MHz, $\left.\mathrm{CDCl}_{3}\right) \delta 148.8,129.3,121.8,116.8,112.4,50.4,38.7,30.9,29.3,25.7,11.5$. IR (neat): 2967, 2928, 2234, 1599, 1505, 1367, 1193, 748, $692 \mathrm{~cm}^{-1}$. HRMS (ESI-TOF) m/z: [M+H] calcd for $\mathrm{C}_{13} \mathrm{H}_{19} \mathrm{~N}_{2} 203.1543$; found 203.1540.

When the reaction was performed at $100^{\circ} \mathrm{C}$ (oil bath) for $10 \mathrm{~h}, \mathbf{2 q}$ could be afforded in $24 \%$ isolated yield (19.8 mg).

\section{Reaction of 8a with $\mathrm{Zn}(\mathrm{CN})_{2}$ in the presence of $n-\mathrm{Bu}_{4} \mathrm{NX}$}

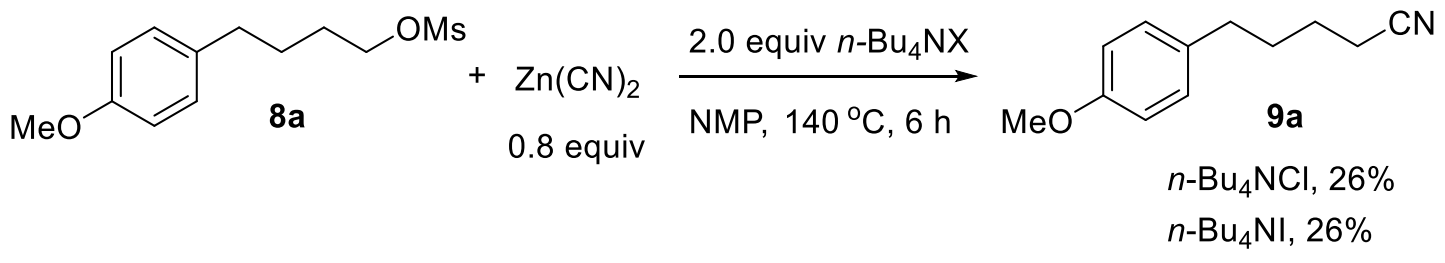


In a nitrogen-filled glove box, $\mathrm{Zn}(\mathrm{CN})_{2}(37.6 \mathrm{mg}, 0.32 \mathrm{mmol}), n-\mathrm{Bu} 4 \mathrm{NCl}(222.3 \mathrm{mg}, 0.8$ $\mathrm{mmol}), 8 \mathbf{a}(103.3 \mathrm{mg}, 0.4 \mathrm{mmol})$ and NMP $(0.4 \mathrm{~mL})$ were added sequentially to a $4 \mathrm{~mL}$ screwcap vial. The vial cap was then securely fitted and taken outside the glove box. After the reaction mixture was stirred at $140^{\circ} \mathrm{C}$ (oil bath) for $6 \mathrm{~h}$, the mixture was filtered through a pad of silica gel and washed with $\mathrm{CH}_{2} \mathrm{Cl}_{2}$. The solvent was evaporated under the reduced pressure and the residue was purified by column chromatography on silica gel (eluent: petroleum ether: ethyl acetate $=10: 1)$ to afford 9a in $26 \%$ isolated yield $(19.5 \mathrm{mg})$ as a colourless oil.

When $n$-Bu $\mathrm{NI}_{4}(295.5 \mathrm{mg}, 0.8 \mathrm{mmol})$ was used instead of $n$-Bu $4 \mathrm{NCl}$, 9a could be formed in $26 \%$ yield $(19.4 \mathrm{mg})$ as a colourless oil.

\section{Optimization studies for cyanation of the primary alkyl mesylates}

In a nitrogen-filled glove box, $\mathrm{NiCl}_{2} \cdot 6 \mathrm{H}_{2} \mathrm{O}(4.8 \mathrm{mg}, 0.02 \mathrm{mmol})$, DMAP (48.9 mg, 0.4 $\mathrm{mmol}), \mathrm{Zn}(\mathrm{CN})_{2}(37.6 \mathrm{mg}, 0.32 \mathrm{mmol})$, zinc powder (10.5 mg, $\left.0.16 \mathrm{mmol}\right), n-\mathrm{Bu} 4 \mathrm{NI}(443.2$ mg, $1.2 \mathrm{mmol}$ ), XantPhos (13.9 mg, $0.024 \mathrm{mmol}), 8 \mathrm{a}(103.3 \mathrm{mg}, 0.4 \mathrm{mmol})$ and $\mathrm{CH}_{3} \mathrm{CN}$ (2.0 $\mathrm{mL}$ ) were added sequentially to a $4 \mathrm{~mL}$ screw-cap vial. The vial cap was then securely fitted and taken outside the glove box. After the reaction mixture was stirred at $100{ }^{\circ} \mathrm{C}$ (oil bath) for $10 \mathrm{~h}$ or at $80{ }^{\circ} \mathrm{C}$ (oil bath) for $24 \mathrm{~h}$, the mixture was filtered through a pad of silica gel and washed with $\mathrm{CH}_{2} \mathrm{Cl}_{2}$. The solvent was evaporated under the reduced pressure and the yields were determined by ${ }^{1} \mathrm{H}$ NMR using 1,3,5-trimethoxybenzene $(67.3 \mathrm{mg}, 0.4 \mathrm{mmol})$ as an internal standard.

Table S9 Optimization studies for cyanation of the primary alkyl mesylates 


\begin{tabular}{|c|c|c|c|}
\hline & $8 a$ & 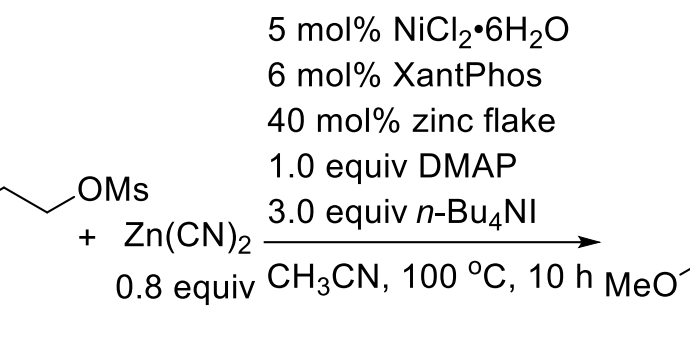 & $9 a$ \\
\hline entry & & deviation from the conditions above & yield of $9 a(\%)^{a}$ \\
\hline 1 & & none & 39 \\
\hline 2 & & no DMAP & 17 \\
\hline 3 & & 2.0 equiv DMAP & 41 \\
\hline 4 & & 2.0 equiv $\mathrm{Cs}_{2} \mathrm{CO}_{3}$ & 29 \\
\hline 5 & & 2.0 equiv quinine, $\mathrm{DBU}$ or $\mathrm{DABCO}$ & trace \\
\hline 6 & & 2.0 equiv DMAP, in DMF & 21 \\
\hline 7 & & 2.0 equiv DMAP, $5 \mathrm{~mol} \% \mathrm{NiCl}_{2}(\mathrm{DME})$ & 28 \\
\hline 8 & & 2.0 equiv DMAP, 6 mol\% dppf & 20 \\
\hline 9 & & $80^{\circ} \mathrm{C}, 24 \mathrm{~h}$ & $56,54^{b}$ \\
\hline 10 & & $60^{\circ} \mathrm{C}, 29 \mathrm{~h}$ & 36 \\
\hline 11 & & 2.0 equiv DMAP, $80^{\circ} \mathrm{C}, 24 \mathrm{~h}$ & 49 \\
\hline 12 & & 0.5 equiv DMAP, $80^{\circ} \mathrm{C}, 24 \mathrm{~h}$ & 54 \\
\hline 13 & & no DMAP, $80^{\circ} \mathrm{C}, 24 \mathrm{~h}$ & 32 \\
\hline 14 & & $5 \mathrm{~mol}^{2} \mathrm{NiCl}_{2}, 80^{\circ} \mathrm{C}, 24 \mathrm{~h}$ & 15 \\
\hline 15 & & $5 \mathrm{~mol} \% \mathrm{Nil}_{2}, 80^{\circ} \mathrm{C}, 24 \mathrm{~h}$ & 24 \\
\hline
\end{tabular}

aYields were determined by ${ }^{1} \mathrm{H}$ NMR using 1,3,5-trimethoxybenzene as an internal standard. ${ }^{b}$ Isolated yield.

\section{Nickel-catalyzed cyanation of primary alkyl mesylates}

Typical procedure for Nickel-catalyzed cyanation of $\mathbf{8 a}$

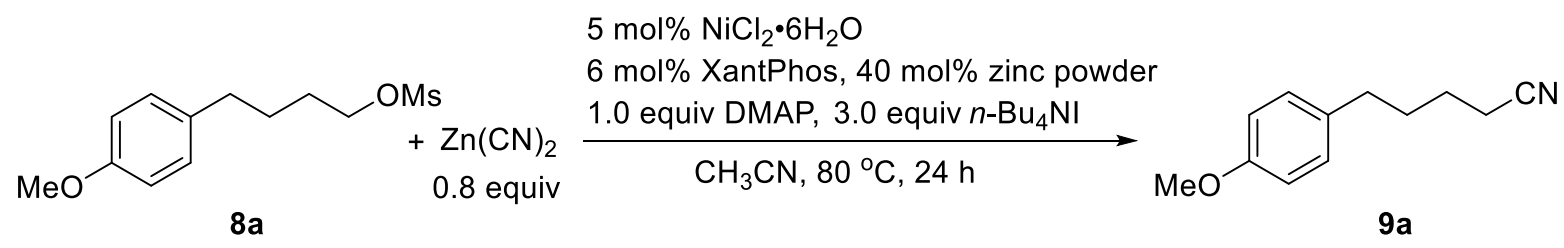

In a nitrogen-filled glove box, $\mathrm{NiCl}_{2} \cdot 6 \mathrm{H}_{2} \mathrm{O}(4.8 \mathrm{mg}, 0.02 \mathrm{mmol})$, DMAP (48.9 mg, 0.4 $\mathrm{mmol}), \mathrm{Zn}(\mathrm{CN})_{2}(37.6 \mathrm{mg}, 0.32 \mathrm{mmol})$, zinc powder (10.5 mg, $\left.0.16 \mathrm{mmol}\right), n$-Bu4NI (443.2 mg, $1.2 \mathrm{mmol})$, XantPhos (13.9 mg, $0.024 \mathrm{mmol}), 8 \mathbf{a}(103.3 \mathrm{mg}, 0.4 \mathrm{mmol})$ and $\mathrm{CH}_{3} \mathrm{CN}(2.0$ $\mathrm{mL}$ ) were added sequentially to a $4 \mathrm{~mL}$ screw-cap vial (If the primary alkyl mesylate is a liquid, it was added after $\mathrm{CH}_{3} \mathrm{CN}$ ). The vial cap was then securely fitted and taken outside the glove box. After the reaction mixture was stirred at $80{ }^{\circ} \mathrm{C}$ (oil bath) for $24 \mathrm{~h}$, the mixture was filtered through a pad of silica gel and washed with $\mathrm{CH}_{2} \mathrm{Cl}_{2}$. The solvent was evaporated under the 
reduced pressure and the yield were determined by ${ }^{1} \mathrm{H}$ NMR using 1,3,5-trimethoxybenzene (67.3 mg, $0.4 \mathrm{mmol}$ ) as an internal standard. The NMR yield of $9 \mathbf{a}$ was 56\%. The residue was purified by column chromatography on silica gel (eluent: petroleum ether: ethyl acetate $=30: 1$ to $10: 1)$ to afford 5-(4-methoxyphenyl)pentanenitrile (9a) in 54\% yield (41.1 $\mathrm{mg}$ ) as a colourless oil. ${ }^{1} \mathrm{H}$ NMR $\left(400 \mathrm{MHz}, \mathrm{CDCl}_{3}\right) \delta 7.08(\mathrm{~d}, J=8.4 \mathrm{~Hz}, 2 \mathrm{H}), 6.83(\mathrm{~d}, J=8.8 \mathrm{~Hz}, 2 \mathrm{H})$, $3.78(\mathrm{~s}, 3 \mathrm{H}), 2.59(\mathrm{t}, J=6.8 \mathrm{~Hz}, 2 \mathrm{H}), 2.32(\mathrm{t}, J=6.8 \mathrm{~Hz}, 2 \mathrm{H}), 1.78-1.62(\mathrm{~m}, 4 \mathrm{H}) ;{ }^{13} \mathrm{C} \mathrm{NMR}$ $\left(100 \mathrm{MHz}, \mathrm{CDCl}_{3}\right) \delta 157.8,133.2,129.2,119.6,113.8,55.2,34.0,30.4,24.7,16.9$. The spectroscopic data is in agreement with that previously reported. ${ }^{13}$<smiles>CC(CC#N)Cc1ccc2c(c1)OCO2</smiles>

4-(Benzo $[d][1,3]$ dioxol-5-yl)-3-methylbutanenitrile (9b). 0.4 mmol scale. $\mathrm{NiCl}_{2} \cdot 6 \mathrm{H}_{2} \mathrm{O}(4.8$ mg, $0.02 \mathrm{mmol})$, DMAP (48.9 mg, $0.4 \mathrm{mmol}), \mathrm{Zn}(\mathrm{CN})_{2}(37.6 \mathrm{mg}, 0.32 \mathrm{mmol})$, zinc powder (10.5 mg, $0.16 \mathrm{mmol}$ ), $n$-Bu+NI (443.2 mg, $1.2 \mathrm{mmol}$ ), XantPhos (13.9 mg, $0.024 \mathrm{mmol}), 8 \mathbf{b}$ (108.9 mg, $0.4 \mathrm{mmol}$ ) and $\mathrm{CH}_{3} \mathrm{CN}(2.0 \mathrm{~mL})$ were stirred at $80{ }^{\circ} \mathrm{C}$ (oil bath) for $24 \mathrm{~h}$. The crude product was purified by column chromatography on silica gel (eluent: petroleum ether: ethyl acetate $=20: 1)$ to afford $9 \mathbf{b}$ in $72 \%$ isolated yield $(58.7 \mathrm{mg})$ as a colourless oil. ${ }^{1} \mathrm{H}$ NMR (400 $\left.\mathrm{MHz}, \mathrm{CDCl}_{3}\right) \delta 6.74(\mathrm{~d}, J=8.0 \mathrm{~Hz}, 1 \mathrm{H}), 6.64-6.60(\mathrm{~m}, 2 \mathrm{H}), 5.93(\mathrm{~s}, 2 \mathrm{H}), 2.62-2.52(\mathrm{~m}, 2 \mathrm{H})$, $2.29(\mathrm{dd}, J=16.8 \mathrm{~Hz}, 5.6 \mathrm{~Hz}, 1 \mathrm{H}), 2.18(\mathrm{dd}, J=16.4 \mathrm{~Hz}, 6.4 \mathrm{~Hz}, 1 \mathrm{H}), 2.12-2.03(\mathrm{~m}, 1 \mathrm{H}), 1.10$ $(\mathrm{d}, J=6.8 \mathrm{~Hz}, 3 \mathrm{H}) ;{ }^{13} \mathrm{C} \mathrm{NMR}\left(100 \mathrm{MHz}, \mathrm{CDCl}_{3}\right) \delta 147.7,146.1,132.6,121.8,118.5,109.1$, 108.2, 100.8, 41.6, 32.5, 23.4, 19.2. IR (neat): 2922, 2244, 1503, 1488, 1441, 1246, 1036, 927 , $802 \mathrm{~cm}^{-1}$. HRMS (EI-TOF) m/z: [M] calcd for $\mathrm{C}_{12} \mathrm{H}_{13} \mathrm{NO}_{2} 203.0941$; found 203.0942 .

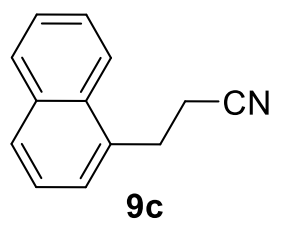

3-(Naphthalen-1-yl)propanenitrile (9c). $0.4 \mathrm{mmol} \mathrm{scale.} \mathrm{NiCl}_{2} \cdot 6 \mathrm{H}_{2} \mathrm{O}(4.8 \mathrm{mg}, 0.02 \mathrm{mmol})$, DMAP (48.9 mg, $0.4 \mathrm{mmol}), \mathrm{Zn}(\mathrm{CN})_{2}(37.6 \mathrm{mg}, 0.32 \mathrm{mmol})$, zinc powder (10.5 mg, 0.16 mmol), $n$-Bu 4 NI (443.2 mg, $1.2 \mathrm{mmol})$, XantPhos (13.9 mg, $0.024 \mathrm{mmol}), 8 \mathrm{c}$ (100.1 mg, 0.4 
mmol) and $\mathrm{CH}_{3} \mathrm{CN}\left(2.0 \mathrm{~mL}\right.$ ) were stirred at $80{ }^{\circ} \mathrm{C}$ (oil bath) for $24 \mathrm{~h}$. The crude product was purified by column chromatography on silica gel (eluent: petroleum ether: ethyl acetate $=20: 1$ to $10: 1)$ to afford $9 \mathrm{c}$ in $75 \%$ isolated yield $(54.3 \mathrm{mg})$ as a colourless oil. ${ }^{1} \mathrm{H}$ NMR $(400 \mathrm{MHz}$, $\left.\mathrm{CDCl}_{3}\right) \delta 7.86(\mathrm{t}, J=7.2 \mathrm{~Hz}, 2 \mathrm{H}), 7.76(\mathrm{~d}, J=8.4 \mathrm{~Hz}, 1 \mathrm{H}), 7.54-7.46(\mathrm{~m}, 2 \mathrm{H}), 7.40(\mathrm{t}, J=7.2$ $\mathrm{Hz}, 1 \mathrm{H}), 7.35(\mathrm{~d}, J=6.8 \mathrm{~Hz}, 1 \mathrm{H}), 3.37(\mathrm{t}, J=7.6 \mathrm{~Hz}, 2 \mathrm{H}), 2.69(\mathrm{t}, J=7.6 \mathrm{~Hz}, 2 \mathrm{H}) ;{ }^{13} \mathrm{C} \mathrm{NMR}$ $\left(100 \mathrm{MHz}, \mathrm{CDCl}_{3}\right) \delta 133.8,133.8,131.0,129.1,128.0,126.4,125.8,125.5,122.5,119.1,28.6$, 18.3. The spectroscopic data is in agreement with that previously reported. ${ }^{14}$<smiles>N#CCCCN1C(=O)c2ccccc2C1=O</smiles>

4-(1,3-Dioxoisoindolin-2-yl)butanenitrile (9d). $0.4 \mathrm{mmol}$ scale. $\mathrm{NiCl}_{2} \cdot 6 \mathrm{H}_{2} \mathrm{O}(4.8 \mathrm{mg}, 0.02$ $\mathrm{mmol}), \mathrm{NaHCO}_{3}(67.2 \mathrm{mg}, 0.8 \mathrm{mmol}), \mathrm{Zn}(\mathrm{CN})_{2}(37.6 \mathrm{mg}, 0.32 \mathrm{mmol})$, zinc powder $(10.5 \mathrm{mg}$, $0.16 \mathrm{mmol}), n$-Bu $4 \mathrm{NI}$ (443.2 mg, $1.2 \mathrm{mmol})$, XantPhos (13.9 mg, $0.024 \mathrm{mmol}), 8 d$ (113.3 mg, $0.4 \mathrm{mmol}$ ) and $\mathrm{CH}_{3} \mathrm{CN}\left(2.0 \mathrm{~mL}\right.$ ) were stirred at $80{ }^{\circ} \mathrm{C}$ (oil bath) for $24 \mathrm{~h}$. The solvent was evaporated under the reduced pressure and the yield were determined by ${ }^{1} \mathrm{H}$ NMR using 1,3,5trimethoxybenzene $(67.3 \mathrm{mg}, 0.4 \mathrm{mmol})$ as an internal standard. The NMR yield of 9d was $70 \%$. The crude product was purified by column chromatography on silica gel (eluent: petroleum ether: ethyl acetate $=10: 1$ to $3: 1)$ to afford $9 \mathbf{d}$ in $72 \%$ isolated yield $(61.3 \mathrm{mg})$ as a white solid. ${ }^{1} \mathrm{H}$ NMR (400 MHz, $\left.\mathrm{CDCl}_{3}\right) \delta$ 7.88-7.83 (m, 2H), 7.77-7.72 (m, 2H), $3.82(\mathrm{t}, J=$ $6.8 \mathrm{~Hz}, 2 \mathrm{H}), 2.45(\mathrm{t}, J=7.2 \mathrm{~Hz}, 2 \mathrm{H}), 2.12-2.05(\mathrm{~m}, 2 \mathrm{H}) ;{ }^{13} \mathrm{C} \mathrm{NMR}\left(100 \mathrm{MHz}, \mathrm{CDCl}_{3}\right) \delta 168.1$, $134.1,131.7,123.3,118.7,36.5,24.6,14.9$. The spectroscopic data is in agreement with that previously reported. ${ }^{9}$

When 1.0 equiv DMAP was used instead of 2.0 equiv $\mathrm{NaHCO}_{3}, 9 \mathbf{d}$ was formed in $50 \%$ NMR yield using 1,3,5-trimethoxybenzene $(67.3 \mathrm{mg}, 0.4 \mathrm{mmol})$ as an internal standard.

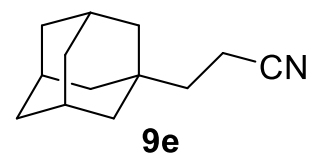

3-((3r,5r,7r)-Adamantan-1-yl)propanenitrile (9e). $0.4 \mathrm{mmol}$ scale. $\mathrm{NiCl}_{2} \cdot 6 \mathrm{H}_{2} \mathrm{O}(4.8 \mathrm{mg}$, S42 
$0.02 \mathrm{mmol})$, DMAP (48.9 mg, $0.4 \mathrm{mmol}), \mathrm{Zn}(\mathrm{CN})_{2}(37.6 \mathrm{mg}, 0.32 \mathrm{mmol})$, zinc powder (10.5 mg, $0.16 \mathrm{mmol}$ ), $n$-Bu $4 \mathrm{NI}$ (443.2 mg, $1.2 \mathrm{mmol}$ ), XantPhos (13.9 mg, $0.024 \mathrm{mmol}), 8 \mathrm{e}$ (103.4 $\mathrm{mg}, 0.4 \mathrm{mmol}$ ) and $\mathrm{CH}_{3} \mathrm{CN}(2.0 \mathrm{~mL})$ were stirred at $80{ }^{\circ} \mathrm{C}$ (oil bath) for $24 \mathrm{~h}$. The crude product was purified by column chromatography on silica gel (eluent: petroleum ether: dichloromethane $=3: 1$ to $2: 1)$ to afford $9 \mathrm{e}$ in $79 \%$ isolated yield $(60.1 \mathrm{mg})$ as a white solid. ${ }^{1} \mathrm{H}$ NMR (400 MHz, $\left.\mathrm{CDCl}_{3}\right) \delta$ 2.29-2.25 (m, 2H), $1.98(\mathrm{~s}, 3 \mathrm{H}), 1.73-1.70(\mathrm{~m}, 3 \mathrm{H}), 1.63-1.60(\mathrm{~m}$, 3H), 1.50-1.46 (m, 8H); ${ }^{13} \mathrm{C}$ NMR (100 MHz, $\left.\mathrm{CDCl}_{3}\right) \delta 120.8,41.5,39.3,36.7,32.0,28.3$, 10.8. The spectroscopic data is in agreement with that previously reported. ${ }^{15}$<smiles>CC(C)(C)OC1C[C@H]2OC(=O)C[C@H]2C1CC#N</smiles>

(3a $R, 4 R, 5 R, 6 a S)-4-(C y a n o m e t h y l)-2-0 x o h e x a h y d r o-2 H$-cyclopenta[b]furan-5-yl

benzoate (9f). $0.4 \mathrm{mmol}$ scale. $\mathrm{NiCl}_{2} \cdot 6 \mathrm{H}_{2} \mathrm{O}$ (4.8 mg, $0.02 \mathrm{mmol}$ ), DMAP (48.9 mg, $\left.0.4 \mathrm{mmol}\right)$, $\mathrm{Zn}(\mathrm{CN})_{2}(37.6 \mathrm{mg}, 0.32 \mathrm{mmol})$, zinc powder (10.5 mg, $\left.0.16 \mathrm{mmol}\right), n$-Bu $4 \mathrm{NI}(443.2 \mathrm{mg}, 1.2$ mmol), XantPhos (13.9 mg, $0.024 \mathrm{mmol}), \mathbf{8 f}(141.7 \mathrm{mg}, 0.4 \mathrm{mmol})$ and $\mathrm{CH}_{3} \mathrm{CN}$ (2.0 mL) were stirred at $80^{\circ} \mathrm{C}$ (oil bath) for $24 \mathrm{~h}$. The crude product was purified by column chromatography on silica gel (eluent: petroleum ether: ethyl acetate $=1: 1$ ) to afford $9 \mathbf{f}$ in $67 \%$ isolated yield (76.9 mg) as a colourless oil. ${ }^{1} \mathrm{H}$ NMR $\left(400 \mathrm{MHz}, \mathrm{CDCl}_{3}\right) \delta 7.99(\mathrm{~d}, J=7.6 \mathrm{~Hz}, 2 \mathrm{H}), 7.58(\mathrm{t}$, $J=7.6 \mathrm{~Hz}, 1 \mathrm{H}), 7.45(\mathrm{t}, J=8.0 \mathrm{~Hz}, 2 \mathrm{H}), 5.25-5.21(\mathrm{~m}, 1 \mathrm{H}), 5.10-5.08(\mathrm{~m}, 1 \mathrm{H}), 2.99-2.92(\mathrm{~m}$, $1 \mathrm{H}), 2.88-2.82(\mathrm{~m}, 1 \mathrm{H}), 2.70-2.53(\mathrm{~m}, 4 \mathrm{H}), 2.48-2.42(\mathrm{~m}, 1 \mathrm{H}), 2.33-2.28(\mathrm{~m}, 1 \mathrm{H}) ;{ }^{13} \mathrm{C} \mathrm{NMR}$ $\left(100 \mathrm{MHz}, \mathrm{CDCl}_{3}\right) \delta 175.6,165.8,133.5,129.5,128.9,128.4,117.3,83.1,78.1,47.7,42.3$, 37.4, 35.0, 19.8. IR (neat): 2249, 1769, 1716, 1271, 1173, 906, 729, $712 \mathrm{~cm}^{-1}$. HRMS (ESITOF) $\mathrm{m} / \mathrm{z}$ : $[\mathrm{M}+\mathrm{Na}]^{+}$calcd for $\mathrm{C}_{16} \mathrm{H}_{15} \mathrm{NO}_{4} \mathrm{Na} 308.0893$; found 308.0893.<smiles>CCc1ccc(CCC#N)nc1</smiles>

3-(5-Ethylpyridin-2-yl)propanenitrile (9g). 0.4 mmol scale. $\mathrm{NiCl}_{2} \cdot 6 \mathrm{H}_{2} \mathrm{O}(9.5 \mathrm{mg}, 0.04$ mmol), DMAP (48.9 mg, $0.4 \mathrm{mmol}), \mathrm{Zn}(\mathrm{CN})_{2}(37.6 \mathrm{mg}, 0.32 \mathrm{mmol})$, zinc powder (10.5 mg, 
$0.16 \mathrm{mmol}), n$-Bu $4 \mathrm{NI}$ (443.2 mg, $1.2 \mathrm{mmol}$ ), XantPhos (27.8 mg, $0.048 \mathrm{mmol}), \mathrm{CH}_{3} \mathrm{CN}$ (2.0 $\mathrm{mL}$ ) and $8 \mathrm{~g}(91.7 \mathrm{mg}, 0.4 \mathrm{mmol})$ were stirred at $80{ }^{\circ} \mathrm{C}$ (oil bath) for $24 \mathrm{~h}$. The solvent was evaporated under the reduced pressure and the yield were determined by ${ }^{1} \mathrm{H}$ NMR using 1,3,5trimethoxybenzene $(67.3 \mathrm{mg}, 0.4 \mathrm{mmol})$ as an internal standard. The NMR yield of $9 \mathrm{~g}$ was $68 \%$. The crude product was purified by column chromatography on silica gel (eluent: petroleum ether: ethyl acetate $=5: 1$ to $3: 1)$ to afford $9 \mathrm{~g}$ in $66 \%$ isolated yield $(42.6 \mathrm{mg})$ as a colourless oil. ${ }^{1} \mathrm{H}$ NMR $\left(400 \mathrm{MHz}, \mathrm{CDCl}_{3}\right) \delta 8.40(\mathrm{~s}, 1 \mathrm{H}), 7.50-7.48(\mathrm{~m}, 1 \mathrm{H}), 7.15(\mathrm{~d}, J=8.0$ $\mathrm{Hz}, 1 \mathrm{H}), 3.09$ (t, $J=7.2 \mathrm{~Hz}, 2 \mathrm{H}), 2.82$ (t, $J=7.2 \mathrm{~Hz}, 2 \mathrm{H}), 2.64$ (q, $J=7.6 \mathrm{~Hz}, 2 \mathrm{H}), 1.25$ (t, $J$ $=7.6 \mathrm{~Hz}, 3 \mathrm{H}) ;{ }^{13} \mathrm{C} \mathrm{NMR}\left(100 \mathrm{MHz}, \mathrm{CDCl}_{3}\right) \delta 154.3,149.1,137.7,136.1,122.6,119.4,32.8$, 25.6, 16.8, 15.2. IR (neat): 2964, 2930, 2244, 1600, 1566, 1488, 1399, 1032, $845 \mathrm{~cm}^{-1}$. HRMS (ESI-TOF) m/z: [M+H] $]^{+}$calcd for $\mathrm{C}_{10} \mathrm{H}_{13} \mathrm{~N}_{2}$ 161.1073; found 161.1074.

When the reaction was performed in the presence of $5 \% \mathrm{NiCl}_{2} \cdot 6 \mathrm{H}_{2} \mathrm{O}$ and $6 \%$ XantPhos instead of $10 \% \mathrm{NiCl}_{2} \cdot 6 \mathrm{H}_{2} \mathrm{O}$ and $12 \%$ XantPhos at $80{ }^{\circ} \mathrm{C}$ (oil bath) for $24 \mathrm{~h}, 9 \mathrm{~g}$ could be formed in 58\% NMR yield using 1,3,5-trimethoxybenzene (67.3 $\mathrm{mg}, 0.4 \mathrm{mmol})$ as an internal standard.

When the reaction was performed in the presence of $5 \% \mathrm{NiCl}_{2} \cdot 6 \mathrm{H}_{2} \mathrm{O}$ and $6 \%$ XantPhos instead of $10 \% \mathrm{NiCl}_{2} \cdot 6 \mathrm{H}_{2} \mathrm{O}$ and $12 \%$ XantPhos at $100{ }^{\circ} \mathrm{C}$ (oil bath) for $19 \mathrm{~h}, 9 \mathrm{~g}$ could be formed in 31\% NMR yield using 1,3,5-trimethoxybenzene (67.3 $\mathrm{mg}, 0.4 \mathrm{mmol})$ as an internal standard.

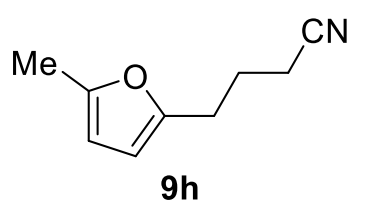

4-(5-Methylfuran-2-yl)butanenitrile (9h). $0.4 \mathrm{mmol} \mathrm{scale.} \mathrm{NiCl}_{2} \cdot 6 \mathrm{H}_{2} \mathrm{O}(4.8 \mathrm{mg}, 0.02 \mathrm{mmol})$, DMAP (48.9 mg, $0.4 \mathrm{mmol}), \mathrm{Zn}(\mathrm{CN})_{2}(37.6 \mathrm{mg}, 0.32 \mathrm{mmol})$, zinc powder (10.5 mg, 0.16 mmol), $n$-Bu 4 NI (443.2 mg, $1.2 \mathrm{mmol}$ ), XantPhos (13.9 mg, $0.024 \mathrm{mmol}), \mathrm{CH}_{3} \mathrm{CN}$ (2.0 mL) and $\mathbf{8 h}$ ( $87.3 \mathrm{mg}, 0.4 \mathrm{mmol}$ ) were stirred at $80{ }^{\circ} \mathrm{C}$ (oil bath) for $24 \mathrm{~h}$. The crude product was purified by column chromatography on silica gel (eluent: petroleum ether: ethyl acetate $=30: 1$ ) to afford $9 \mathrm{~h}$ in $46 \%$ isolated yield $(27.5 \mathrm{mg})$ as a colourless oil. ${ }^{1} \mathrm{H} \mathrm{NMR}\left(400 \mathrm{MHz}, \mathrm{CDCl}_{3}\right) \delta$ 5.93-5.92 (m, 1H), 5.86-5.85 (m, 1H), 2.74 (t, $J=7.2 \mathrm{~Hz}, 2 \mathrm{H}), 2.36$ (t, $J=7.2 \mathrm{~Hz}, 2 \mathrm{H}), 2.25$ (s, 3H), 1.98 (quint, $J=7.2 \mathrm{~Hz}, 2 \mathrm{H}) ;{ }^{13} \mathrm{C} \mathrm{NMR}\left(100 \mathrm{MHz}, \mathrm{CDCl}_{3}\right) \delta 151.3,151.0,119.3,106.8$, 105.9, 26.7, 24.1, 16.3, 13.4. IR (neat): 2922, 2244, 1569, 1434, 1217, 1020, 939, $783 \mathrm{~cm}^{-1}$. 
HRMS (EI-TOF) m/z: [M] $]^{+}$calcd for $\mathrm{C}_{9} \mathrm{H}_{11} \mathrm{NO}$ 149.0835; found 149.0837 .

When the reaction was performed in the presence of $10 \% \mathrm{NiCl}_{2} \cdot 6 \mathrm{H}_{2} \mathrm{O}$ and $12 \%$ XantPhos instead of $5 \% \mathrm{NiCl}_{2} \cdot 6 \mathrm{H}_{2} \mathrm{O}$ and $6 \%$ XantPhos at $80{ }^{\circ} \mathrm{C}$ (oil bath) for $24 \mathrm{~h}, 9 \mathrm{~h}$ could be afforded in $54 \%$ isolated yield $(32.1 \mathrm{mg})$ as a colourless oil.<smiles>N#CCCCc1ccccc1</smiles>

$9 \mathbf{i}$

4-Phenylbutanenitrile (9i). $0.4 \mathrm{mmol}$ scale. $\mathrm{NiCl}_{2} \cdot 6 \mathrm{H}_{2} \mathrm{O}$ (4.8 mg, $\left.0.02 \mathrm{mmol}\right)$, DMAP (48.9 $\mathrm{mg}, 0.4 \mathrm{mmol}), \mathrm{Zn}(\mathrm{CN})_{2}(37.6 \mathrm{mg}, 0.32 \mathrm{mmol})$, zinc powder (10.5 mg, $\left.0.16 \mathrm{mmol}\right), n-\mathrm{Bu} 4 \mathrm{NI}$ (443.2 mg, $1.2 \mathrm{mmol})$, XantPhos (13.9 mg, $0.024 \mathrm{mmol}), \mathrm{CH}_{3} \mathrm{CN}(2.0 \mathrm{~mL})$ and $8 \mathbf{i}(85.7 \mathrm{mg}$, $0.4 \mathrm{mmol}$ ) were stirred at $80{ }^{\circ} \mathrm{C}$ (oil bath) for $24 \mathrm{~h}$. The crude product was purified by column chromatography on silica gel (eluent: petroleum ether: dichloromethane $=3: 1$ to $2: 1$ ) to afford $9 \mathbf{i}$ in $54 \%$ isolated yield $(31.2 \mathrm{mg})$ as a colourless oil. ${ }^{1} \mathrm{H}$ NMR $\left(400 \mathrm{MHz}, \mathrm{CDCl}_{3}\right) \delta 7.32-7.17$ $(\mathrm{m}, 5 \mathrm{H}), 2.77$ (t, $J=7.2 \mathrm{~Hz}, 2 \mathrm{H}), 2.30$ (t, $J=7.2 \mathrm{~Hz}, 2 \mathrm{H}), 1.97$ (quint, $J=7.2 \mathrm{~Hz}, 2 \mathrm{H}$ ); ${ }^{13} \mathrm{C}$ NMR $\left(100 \mathrm{MHz}, \mathrm{CDCl}_{3}\right) \delta 139.6,128.6,128.4,126.4,119.5,34.3,26.8,16.3$. The spectroscopic data is in agreement with that previously reported. ${ }^{9}$

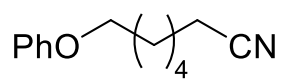

9j

7-Phenoxyheptanenitrile (9j). $0.4 \mathrm{mmol}$ scale. $\mathrm{NiCl}_{2} \cdot 6 \mathrm{H}_{2} \mathrm{O}(9.5 \mathrm{mg}, 0.04 \mathrm{mmol})$, DMAP (48.9 mg, $0.4 \mathrm{mmol}), \mathrm{Zn}(\mathrm{CN})_{2}(37.6 \mathrm{mg}, 0.32 \mathrm{mmol})$, zinc powder (10.5 mg, $\left.0.16 \mathrm{mmol}\right), n$ $\mathrm{Bu}_{4} \mathrm{NI}$ (443.2 mg, $\left.1.2 \mathrm{mmol}\right)$, XantPhos (27.8 mg, $\left.0.048 \mathrm{mmol}\right), \mathrm{CH}_{3} \mathrm{CN}(2.0 \mathrm{~mL})$ and $8 \mathbf{j}$ (108.9 mg, $0.4 \mathrm{mmol}$ ) were stirred at $80{ }^{\circ} \mathrm{C}$ (oil bath) for $24 \mathrm{~h}$. The crude product was purified by column chromatography on silica gel (eluent: petroleum ether: ethyl acetate $=20: 1$ to $10: 1$ ) to afford $9 \mathbf{j}$ in $59 \%$ isolated yield $(47.8 \mathrm{mg})$ as a yellow oil. ${ }^{1} \mathrm{H} \mathrm{NMR}\left(400 \mathrm{MHz}, \mathrm{CDCl}_{3}\right) \delta 7.29-$ $7.24(\mathrm{~m}, 2 \mathrm{H}), 6.95-6.87(\mathrm{~m}, 3 \mathrm{H}), 3.95(\mathrm{t}, J=6.4 \mathrm{~Hz}, 2 \mathrm{H}), 2.33(\mathrm{t}, J=6.8 \mathrm{~Hz}, 2 \mathrm{H}), 1.82-1.76$ $(\mathrm{m}, 2 \mathrm{H}), 1.71-1.63(\mathrm{~m}, 2 \mathrm{H}), 1.53-1.49(\mathrm{~m}, 4 \mathrm{H}) ;{ }^{13} \mathrm{C} \mathrm{NMR}\left(100 \mathrm{MHz}, \mathrm{CDCl}_{3}\right) \delta 158.9,129.3$, 120.5, 119.7, 114.3, 67.3, 28.9, 28.3, 25.3, 25.2, 17.0. IR (neat): 2937, 2242, 1599, 1585, 1496, 1472, 1243, 1172, 1032, 754, $692 \mathrm{~cm}^{-1}$. HRMS (EI-TOF) m/z: [M] ${ }^{+}$calcd for $\mathrm{C}_{13} \mathrm{H}_{17} \mathrm{NO}$ 203.1305; found 203.1307. 


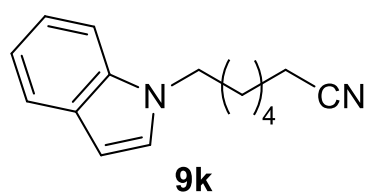

7-(1H-Indol-1-yl)heptanenitrile (9k). $0.4 \mathrm{mmol}$ scale. $\mathrm{NiCl}_{2} \cdot 6 \mathrm{H}_{2} \mathrm{O}(9.5 \mathrm{mg}, 0.04 \mathrm{mmol})$, DMAP (48.9 mg, $0.4 \mathrm{mmol}), \mathrm{Zn}(\mathrm{CN})_{2}(37.6 \mathrm{mg}, 0.32 \mathrm{mmol})$, zinc powder (10.5 mg, 0.16 mmol), $n$-Bu 4 NI (443.2 mg, $1.2 \mathrm{mmol}$ ), XantPhos (27.8 mg, $0.048 \mathrm{mmol}), \mathrm{CH}_{3} \mathrm{CN}(2.0 \mathrm{~mL})$ and $8 \mathbf{k}\left(118.2 \mathrm{mg}, 0.4 \mathrm{mmol}\right.$ ) were stirred at $60^{\circ} \mathrm{C}$ (oil bath) for $26 \mathrm{~h}$. The crude product was purified by column chromatography on silica gel (eluent: petroleum ether: ethyl acetate $=10: 1$ ) to afford 9k in $66 \%$ isolated yield $(59.9 \mathrm{mg})$ as a yellow oil. ${ }^{1} \mathrm{H} \mathrm{NMR}\left(400 \mathrm{MHz}, \mathrm{CDCl}_{3}\right) \delta$ $7.62(\mathrm{~d}, J=8.0 \mathrm{~Hz}, 1 \mathrm{H}), 7.31(\mathrm{~d}, J=8.0 \mathrm{~Hz}, 1 \mathrm{H}), 7.21-7.17(\mathrm{~m}, 1 \mathrm{H}), 7.10-7.05(\mathrm{~m}, 2 \mathrm{H}), 6.47$ $(\mathrm{d}, J=2.8 \mathrm{~Hz}, 1 \mathrm{H}), 4.08(\mathrm{t}, J=6.8 \mathrm{~Hz}, 2 \mathrm{H}), 2.22(\mathrm{t}, J=6.8 \mathrm{~Hz}, 2 \mathrm{H}), 1.85-1.77(\mathrm{~m}, 2 \mathrm{H}), 1.59$ $1.52(\mathrm{~m}, 2 \mathrm{H}), 1.44-1.37(\mathrm{~m}, 2 \mathrm{H}), 1.32-1.24(\mathrm{~m}, 2 \mathrm{H}) ;{ }^{13} \mathrm{C} \mathrm{NMR}\left(100 \mathrm{MHz}, \mathrm{CDCl}_{3}\right) \delta$ 135.7, 128.4, 127.6, 121.2, 120.8, 119.6, 119.1, 109.2, 100.9, 46.0, 29.8, 28.1, 26.0, 25.0, 16.8. IR (neat): 2933. 2855, 2242, 1510, 1463, 1314, 764, $739 \mathrm{~cm}^{-1}$. HRMS (ESI-TOF) m/z: $[\mathrm{M}+\mathrm{H}]^{+}$ calcd for $\mathrm{C}_{15} \mathrm{H}_{19} \mathrm{~N}_{2} 227.1543$; found 227.1543.

When the reaction was performed at $80{ }^{\circ} \mathrm{C}$ (oil bath) for $24 \mathrm{~h}, 9 \mathbf{k}$ could be afforded in $14 \%$ isolated yield (12.6 mg) as a yellow oil.<smiles>CC(C)(CC#N)CNC(=O)c1ccccc1</smiles>

$\mathrm{N}$-(6-Cyanohexyl)benzamide (9l). $0.4 \mathrm{mmol}$ scale. $\mathrm{NiCl}_{2} \cdot 6 \mathrm{H}_{2} \mathrm{O}$ (9.5 mg, $\left.0.04 \mathrm{mmol}\right)$, DMAP (48.9 mg, $0.4 \mathrm{mmol}), \mathrm{Zn}(\mathrm{CN})_{2}(37.6 \mathrm{mg}, 0.32 \mathrm{mmol})$, zinc powder (10.5 mg, $\left.0.16 \mathrm{mmol}\right), n$ $\mathrm{Bu}_{4} \mathrm{NI}$ (443.2 mg, $\left.1.2 \mathrm{mmol}\right)$, XantPhos (27.8 mg, $\left.0.048 \mathrm{mmol}\right), \mathrm{CH}_{3} \mathrm{CN}$ (2.0 mL) and $8 \mathrm{l}$ (119.8 $\mathrm{mg}, 0.4 \mathrm{mmol}$ ) were stirred at $80{ }^{\circ} \mathrm{C}$ (oil bath) for $24 \mathrm{~h}$. The crude product was purified by column chromatography on silica gel (eluent: petroleum ether: ethyl acetate $=2: 1$ to $1: 1$ ) to afford 91 in $56 \%$ isolated yield $(52.0 \mathrm{mg})$ as a colourless oil. ${ }^{1} \mathrm{H} \mathrm{NMR}\left(400 \mathrm{MHz}, \mathrm{CDCl}_{3}\right) \delta$ 7.79-7.77 (m, 2H), 7.50-7.46 (m, 1H), 7.42-7.38 (m, 2H), $6.74(\mathrm{bs}, 1 \mathrm{H}), 3.41$ (q, $J=6.8 \mathrm{~Hz}$, 2H), $2.31(\mathrm{t}, J=7.2 \mathrm{~Hz}, 2 \mathrm{H}), 1.67-1.54(\mathrm{~m}, 4 \mathrm{H}), 1.50-1.33(\mathrm{~m}, 4 \mathrm{H}) ;{ }^{13} \mathrm{C}$ NMR $(100 \mathrm{MHz}$, 
$\left.\mathrm{CDCl}_{3}\right) \delta 167.5,134.5,131.2,128.3,126.8,119.7,39.6,29.2,28.1,25.9,25.0,16.8$. IR (neat): 3327, 2928, 2857, 2244, 1636, 1537, 1489, 1306, 711, 694, $668 \mathrm{~cm}^{-1}$. HRMS (ESI-TOF) m/z: $[\mathrm{M}+\mathrm{H}]^{+}$calcd for $\mathrm{C}_{14} \mathrm{H}_{19} \mathrm{~N}_{2} \mathrm{O} 231.1492$; found 231.1494.

\section{$1 \mathrm{mmol}$ scale reaction of $1 \mathrm{a}$.}

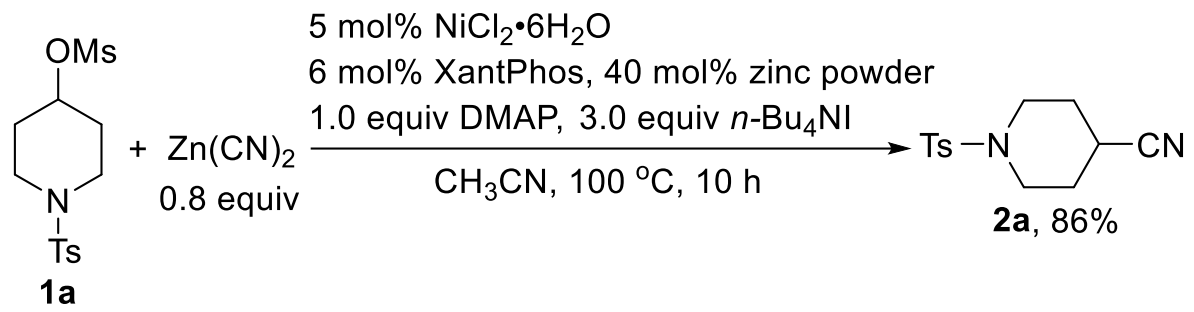

A sealable Schlenk tube was dried under vacuum using a heatgun, and evacuated and backfilled with argon for several times. Then $\mathrm{NiCl}_{2} \cdot 6 \mathrm{H}_{2} \mathrm{O}(11.9 \mathrm{mg}, 0.05 \mathrm{mmol})$, DMAP (122.2 mg, $1.0 \mathrm{mmol}), \mathrm{Zn}(\mathrm{CN})_{2}(93.9 \mathrm{mg}, 0.8 \mathrm{mmol})$, zinc powder (26.2 mg, $\left.0.4 \mathrm{mmol}\right), n$-Bu4 $\mathrm{NI}(1.11 \mathrm{~g}$, $3.0 \mathrm{mmol})$, XantPhos (34.7 mg, $0.06 \mathrm{mmol}), \mathbf{1 a}(333.4 \mathrm{mg}, 1.0 \mathrm{mmol})$ were added under argon. The tube was evacuated and refilled with argon for three times, and then acetonitrile $(5.0 \mathrm{~mL})$ was added via syringe. The Schlenk tube was sealed and immersed into an oil bath preheated at $100{ }^{\circ} \mathrm{C}$. After stirring for $10 \mathrm{~h}$, the mixture was cooled down to room temperature. Then the reaction mixture was filtered through a short pad of silica gel and washed with $\mathrm{CH}_{2} \mathrm{Cl}_{2}$. The solvent was evaporated under the reduced pressure and the residue was purified by column chromatography on silica gel (eluent: petroleum ether: ethyl acetate $=10: 1$ to $2: 1$ ) to afford $\mathbf{2 a}$ in $86 \%$ yield $(227.9 \mathrm{mg})$ as a white solid.

\section{Reaction of 3a under the standard conditions for alkyl halides reported in our previous paper}

1) Reaction of 3a under the standard conditions for alkyl chlorides reported in our previous paper 


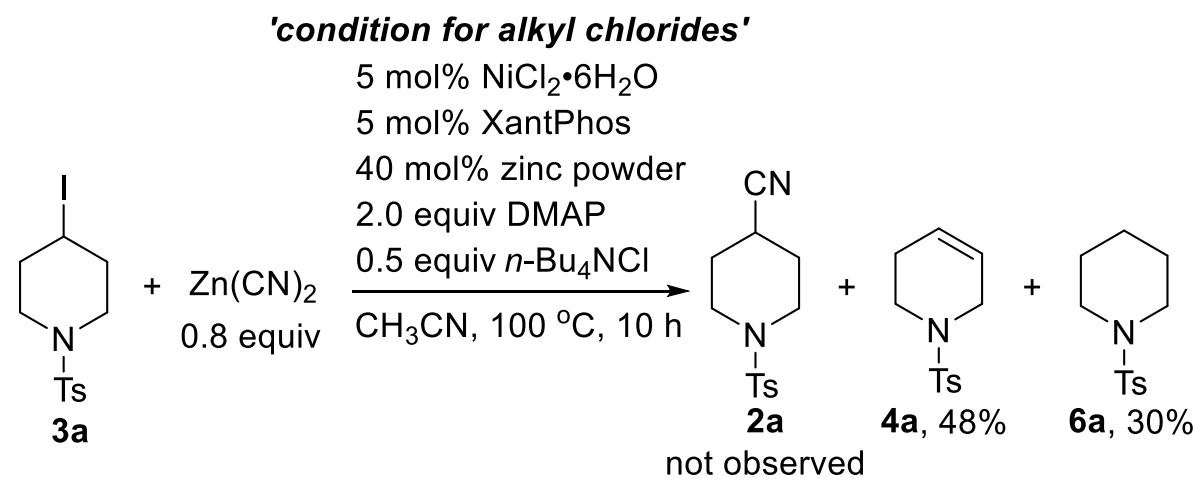

In a nitrogen-filled glove box, $\mathrm{NiCl}_{2} \cdot 6 \mathrm{H}_{2} \mathrm{O}(2.4 \mathrm{mg}, 0.01 \mathrm{mmol})$, DMAP (48.9 mg, 0.4 $\mathrm{mmol}), \mathrm{Zn}(\mathrm{CN})_{2}(18.8 \mathrm{mg}, 0.16 \mathrm{mmol})$, zinc powder (5.2 mg, $\left.0.08 \mathrm{mmol}\right), n-\mathrm{Bu} 4 \mathrm{NCl}(27.8 \mathrm{mg}$, $0.1 \mathrm{mmol})$, XantPhos (5.8 mg, $0.01 \mathrm{mmol}), 3 \mathbf{a}(73.0 \mathrm{mg}, 0.2 \mathrm{mmol})$ and $\mathrm{CH}_{3} \mathrm{CN}(0.4 \mathrm{~mL})$ were added sequentially to a $4 \mathrm{~mL}$ screw-cap vial. The vial cap was then securely fitted and taken outside the glove box. After the reaction mixture was stirred at $100{ }^{\circ} \mathrm{C}$ (oil bath) for $10 \mathrm{~h}$, the mixture was filtered through a pad of silica gel and washed with $\mathrm{CH}_{2} \mathrm{Cl}_{2}$. The solvent was evaporated under the reduced pressure and the yield were determined by ${ }^{1} \mathrm{H}$ NMR using 1,3,5trimethoxybenzene (33.6 $\mathrm{mg}, 0.2 \mathrm{mmol}$ ) as an internal standard, no desired product (2a) was observed, the NMR yield of $\mathbf{4 a}$ was $48 \%$, the NMR yield of $\mathbf{6 a}$ was $30 \%$.

The results indicated that under these conditions, the desired product $2 \mathbf{a}$ was not formed.

2) Reaction of 3a under standard conditions for alkyl bromides reported in our previous paper

\section{'condition for alkyl bromides'}

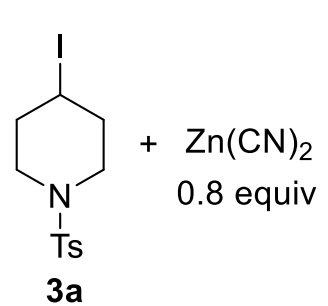

$5 \mathrm{~mol} \% \mathrm{Ni}(\mathrm{acac})_{2}$

$5 \mathrm{~mol} \%$ XantPhos

$40 \mathrm{~mol} \%$ zinc powder

$\underset{\mathrm{CH}_{3} \mathrm{CN}, 80^{\circ} \mathrm{C}, 12 \mathrm{~h}}{\longrightarrow}$

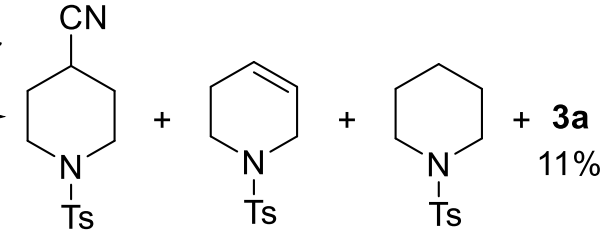

$2 a \quad 4 a, 36 \%$

$6 a, 37 \%$

not observed

In a nitrogen-filled glove box, $\mathrm{Ni}(\text { acac })_{2}(2.6 \mathrm{mg}, 0.01 \mathrm{mmol}), \mathrm{DMAP}(48.9 \mathrm{mg}, 0.4 \mathrm{mmol})$, $\mathrm{Zn}(\mathrm{CN})_{2}(18.8 \mathrm{mg}, 0.16 \mathrm{mmol})$, zinc powder (5.2 mg, $\left.0.08 \mathrm{mmol}\right)$, XantPhos (5.8 mg, 0.01 mmol), 3a (73.0 mg, $0.2 \mathrm{mmol})$ and $\mathrm{CH}_{3} \mathrm{CN}(0.4 \mathrm{~mL})$ were added sequentially to a $4 \mathrm{~mL}$ screwcap vial. The vial cap was then securely fitted and taken outside the glove box. After the reaction mixture was stirred at $80{ }^{\circ} \mathrm{C}$ (oil bath) for $12 \mathrm{~h}$, the mixture was filtered through a pad of silica gel and washed with $\mathrm{CH}_{2} \mathrm{Cl}_{2}$. The solvent was evaporated under the reduced pressure 
and the yield were determined by ${ }^{1} \mathrm{H}$ NMR using 1,3,5-trimethoxybenzene (33.6 mg, $0.2 \mathrm{mmol}$ ) as an internal standard, no desired product (2a) was observed, the NMR yield of $\mathbf{4 a}$ was $36 \%$, the NMR yield of $\mathbf{6 a}$ was $37 \%$, and the NMR yield of unreacted $\mathbf{3 a}$ was $11 \%$.

The results indicated that under these conditions, the desired product $\mathbf{2 a}$ was not formed.

\section{Mechanistic studies:}

1) Reaction of $1 \mathrm{a}$ with $n$-Bu $4 \mathrm{NI}$ in the absence of $\mathrm{Zn}(\mathrm{CN})_{2}$

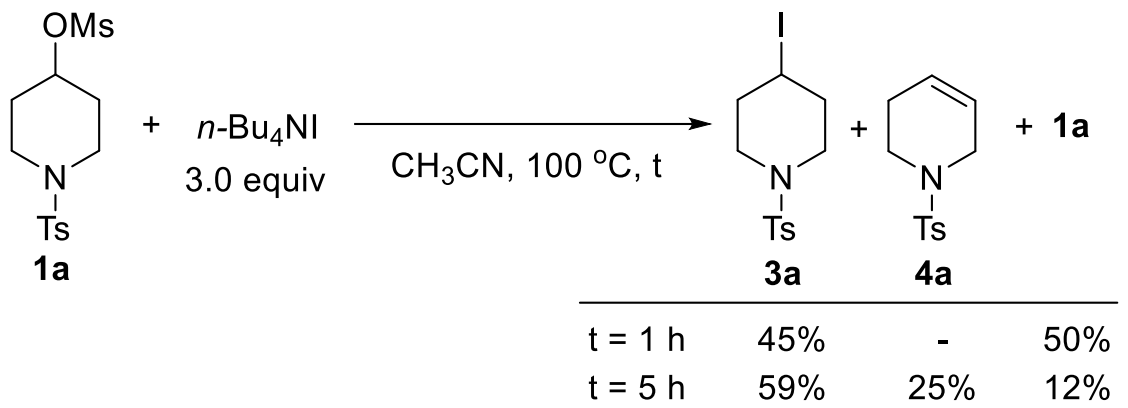

For $\mathrm{t}=1 \mathrm{~h}$ : In a nitrogen-filled glove box, $n$-Bu $4 \mathrm{NI}(221.6 \mathrm{mg}, 0.6 \mathrm{mmol}), \mathbf{1 a}(66.7 \mathrm{mg}$, $0.2 \mathrm{mmol})$ and $\mathrm{CH}_{3} \mathrm{CN}(1 \mathrm{~mL})$ were added sequentially to a $4 \mathrm{~mL}$ screw-cap vial. The vial cap was then securely fitted and taken outside the glove box. After the reaction mixture was stirred at $100{ }^{\circ} \mathrm{C}$ (oil bath) for $1 \mathrm{~h}$, the mixture was filtered through a pad of silica gel and washed with $\mathrm{CH}_{2} \mathrm{Cl}_{2}$. The solvent was evaporated under the reduced pressure and the yields were determined by ${ }^{1} \mathrm{H}$ NMR using 1,3,5-trimethoxybenzene $(33.6 \mathrm{mg}, 0.2 \mathrm{mmol}$ ) as an internal standard, the NMR yield of $\mathbf{3 a}$ was $45 \%$, and the NMR yield of $\mathbf{1 a}$ was $50 \%$.

For $\mathrm{t}=5 \mathrm{~h}$ : In a nitrogen-filled glove box, $n$-Bu $4 \mathrm{NI}(443.2 \mathrm{mg}, 1.2 \mathrm{mmol}), \mathbf{1 a}(133.4 \mathrm{mg}$, $0.4 \mathrm{mmol})$ and $\mathrm{CH}_{3} \mathrm{CN}(2 \mathrm{~mL})$ were added sequentially to a $4 \mathrm{~mL}$ screw-cap vial. The vial cap was then securely fitted and taken outside the glove box. After the reaction mixture was stirred at $100{ }^{\circ} \mathrm{C}$ (oil bath) for $5 \mathrm{~h}$, the mixture was filtered through a pad of silica gel and washed with $\mathrm{CH}_{2} \mathrm{Cl}_{2}$. The solvent was evaporated under the reduced pressure and the yields were determined by ${ }^{1} \mathrm{H}$ NMR using 1,3,5-trimethoxybenzene $(67.3 \mathrm{mg}, 0.4 \mathrm{mmol})$ as an internal standard, the NMR yield of 3a was $59 \%$, the NMR yield of $4 \mathbf{a}$ was $25 \%$, and $1 \mathbf{a}$ was observed in $12 \%$ NMR yield.

2) Reaction of $1 \mathbf{a}$ in the presence of $\mathrm{Zn}(\mathrm{CN})_{2}$ with or without $n$-Bu $\mathrm{Bu}_{4}$ 


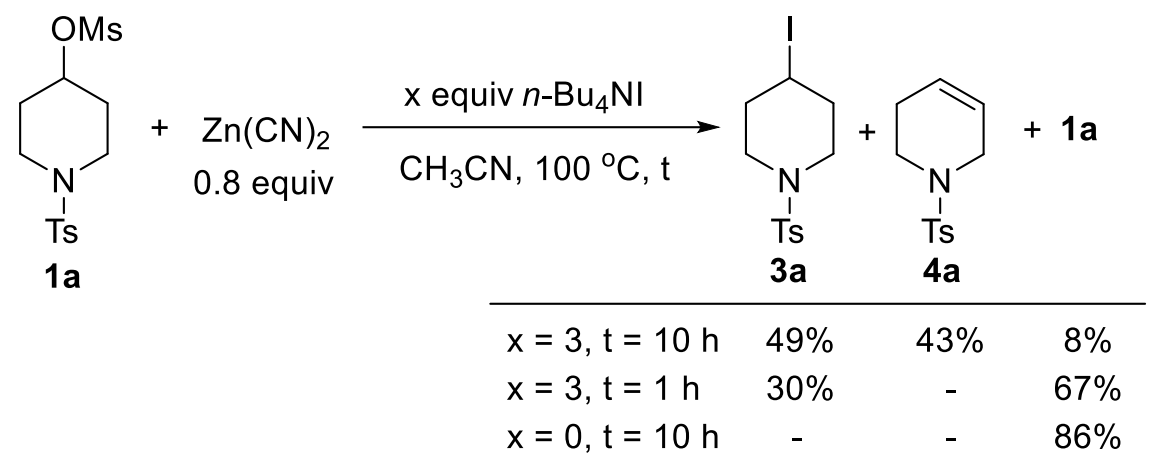

In a nitrogen-filled glove box, $\mathrm{Zn}(\mathrm{CN})_{2}(37.6 \mathrm{mg}, 0.32 \mathrm{mmol}), n$-Bu $4 \mathrm{NI}$ (443.2 mg, 1.2 mmol), $1 \mathrm{a}(133.4 \mathrm{mg}, 0.4 \mathrm{mmol})$ and $\mathrm{CH}_{3} \mathrm{CN}(2 \mathrm{~mL})$ were added sequentially to a $4 \mathrm{~mL}$ screwcap vial. The vial cap was then securely fitted and taken outside the glove box. After the reaction mixture was stirred at $100{ }^{\circ} \mathrm{C}$ (oil bath) for $10 \mathrm{~h}$, the mixture was filtered through a pad of silica gel and washed with $\mathrm{CH}_{2} \mathrm{Cl}_{2}$. The solvent was evaporated under the reduced pressure and the yields were determined by ${ }^{1} \mathrm{H}$ NMR using 1,3,5-trimethoxybenzene (67.3 mg, $0.4 \mathrm{mmol}$ ) as an internal standard. The NMR yield of $\mathbf{3 a}$ was $49 \%$, the NMR yield of $4 \mathbf{a}$ was $43 \%$, and $1 \mathrm{a}$ was observed in $8 \%$ NMR yield.

When the reaction was performed in the presence of 3.0 equiv $n$-Bu $\mathrm{NI}_{4}$ for $1 \mathrm{~h}, \mathbf{1 a}$ was observed in 67\% NMR yield, and 3a was formed in 30\% NMR yield using 1,3,5trimethoxybenzene $(67.3 \mathrm{mg}, 0.4 \mathrm{mmol})$ as an internal standard.

When the reaction was performed without $n$-Bu 4 NI for 10 h, $\mathbf{1 a}$ was recovered in $86 \%$ NMR yield using 1,3,5-trimethoxybenzene $(67.3 \mathrm{mg}, 0.4 \mathrm{mmol})$ as an internal standard.

3) Reaction of 3a under the standard conditions for alkyl mesylates

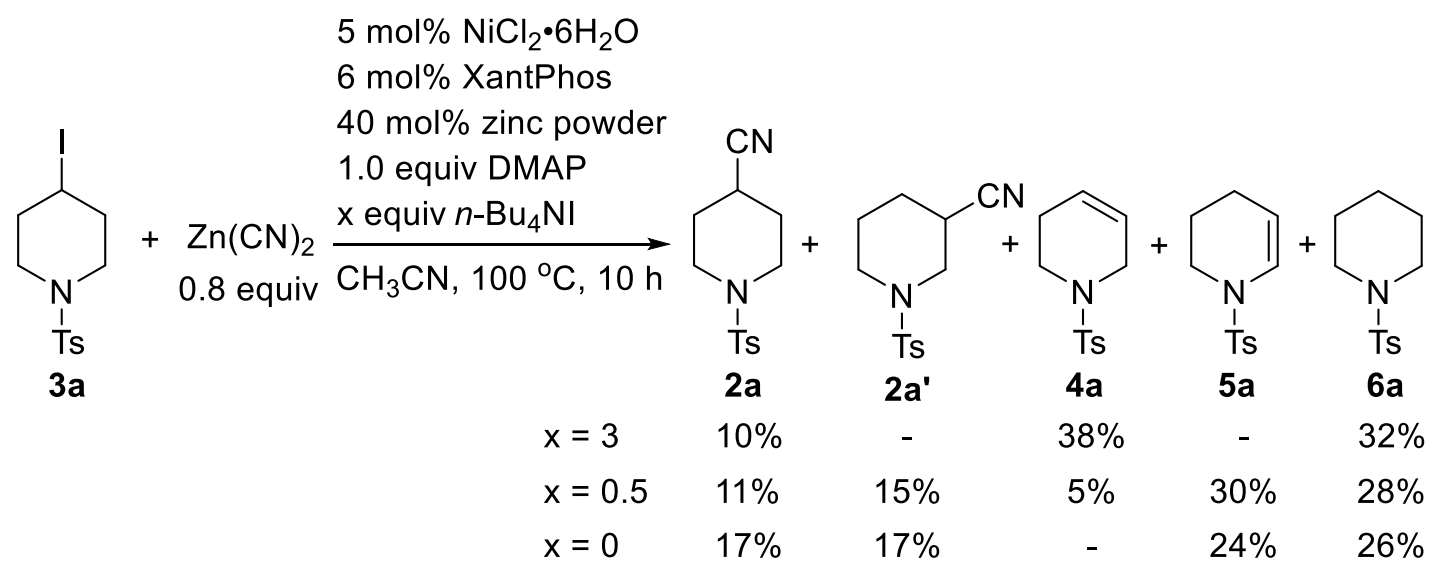

In a nitrogen-filled glove box, $\mathrm{NiCl}_{2} \cdot 6 \mathrm{H}_{2} \mathrm{O}(4.8 \mathrm{mg}, 0.02 \mathrm{mmol})$, DMAP (48.9 mg, 0.4 
$\mathrm{mmol}), \mathrm{Zn}(\mathrm{CN})_{2}(37.6 \mathrm{mg}, 0.32 \mathrm{mmol})$, zinc powder (10.5 mg, $\left.0.16 \mathrm{mmol}\right), n$-Bu $4 \mathrm{NI}$, XantPhos (13.9 mg, $0.024 \mathrm{mmol}), 3 \mathrm{a}(146.1 \mathrm{mg}, 0.4 \mathrm{mmol})$ and $\mathrm{CH}_{3} \mathrm{CN}(2.0 \mathrm{~mL})$ were added sequentially to a $4 \mathrm{~mL}$ screw-cap vial. The vial cap was then securely fitted and taken outside the glove box. After the reaction mixture was stirred at $100{ }^{\circ} \mathrm{C}$ (oil bath) for $10 \mathrm{~h}$, the mixture was filtered through a pad of silica gel and washed with $\mathrm{CH}_{2} \mathrm{Cl}_{2}$. The solvent was evaporated under the reduced pressure.

When $\mathrm{x}=3, n$-Bu4NI (443.2 $\mathrm{mg}, 1.2 \mathrm{mmol}$ ) was used; Using 1,3,5-trimethoxybenzene (67.3 $\mathrm{mg}, 0.4 \mathrm{mmol}$ ) as an internal standard, the NMR yield of $4 \mathbf{a}$ was $38 \%$ and the NMR yield of $6 \mathbf{a}$ was $32 \%$; The crude product was purified by column chromatography on silica gel (eluent: petroleum ether: ethyl acetate $=10: 1$ to $2: 1)$ to afford $\mathbf{2 a}$ in $10 \%$ isolated yield $(10.8 \mathrm{mg})$ as a white solid.

When $\mathrm{x}=0.5, n$-Bu4NI (73.9 mg, $0.2 \mathrm{mmol})$ was used; Using 1,3,5-trimethoxybenzene $(67.3 \mathrm{mg}, 0.4 \mathrm{mmol})$ as an internal standard, the NMR yield of $\mathbf{4 a}$ was $5 \%$, the NMR yield of 5a was $30 \%$ and the NMR yield of $\mathbf{6 a}$ was $28 \%$; The crude product was purified by preparative TLC on silica gel (eluent: petroleum ether: ethyl acetate $=2: 1$ ) to afford a mixture of $\mathbf{2 a}$ and $\mathbf{2 a}^{\prime}(26.8 \mathrm{mg})$ in a ratio of $1: 1.37$. The yield of $\mathbf{2 a}$ was $11 \%$ and the yield of $\mathbf{2} \mathbf{a}^{\prime}$ was $15 \%$.

When $\mathrm{x}=0$, no $n$-Bu $4 \mathrm{NI}$ was used; Using 1,3,5-trimethoxybenzene (67.3 $\mathrm{mg}, 0.4 \mathrm{mmol})$ as an internal standard, the NMR yield of $5 \mathbf{a}$ was $24 \%$ and the NMR yield of $6 \mathbf{a}$ was $26 \%$; The crude product was purified by preparative TLC on silica gel (eluent: petroleum ether: ethyl acetate $=2: 1)$ to afford a mixture of $\mathbf{2} \mathbf{a}$ and $\mathbf{2} \mathbf{a}^{\prime}(35.0 \mathrm{mg})$ in a ratio of $1: 1$. The yield of $\mathbf{2} \mathbf{a}$ was $17 \%$ and the yield of $\mathbf{2} \mathbf{a}^{\prime}$ was $17 \%$.

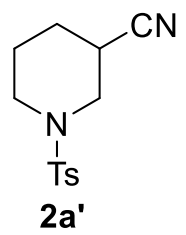

1-tosylpiperidine-3-carbonitrile (2a'). ${ }^{1} \mathrm{H} \mathrm{NMR}\left(400 \mathrm{MHz}, \mathrm{CDCl}_{3}\right) \delta 7.65(\mathrm{~d}, J=8.0 \mathrm{~Hz}, 2 \mathrm{H})$, 7.36-7.34 (m, 2H), 3.60-3.58 (m, 1H), 3.37-3.34 (m, 1H), 2.86-2.84 (m, 2H), 2.75-2.67 (m, 1H), 2.44 (s, 3H), 2.03-1.84 (m, 2H), 1.69-1.61 (m, 2H); $\left.{ }^{13} \mathrm{C} \mathrm{NMR} \mathrm{(100} \mathrm{MHz,} \mathrm{CDCl}_{3}\right) \delta 144.1$, $132.8,129.8,127.5,119.3,47.6,45.8,27.3,27.1,23.0,21.5$. The spectroscopic data is in 
agreement with that previously reported. ${ }^{16}$

4) Portionwise addition of $\mathbf{3 a}$ under the standard conditions for alkyl mesylates

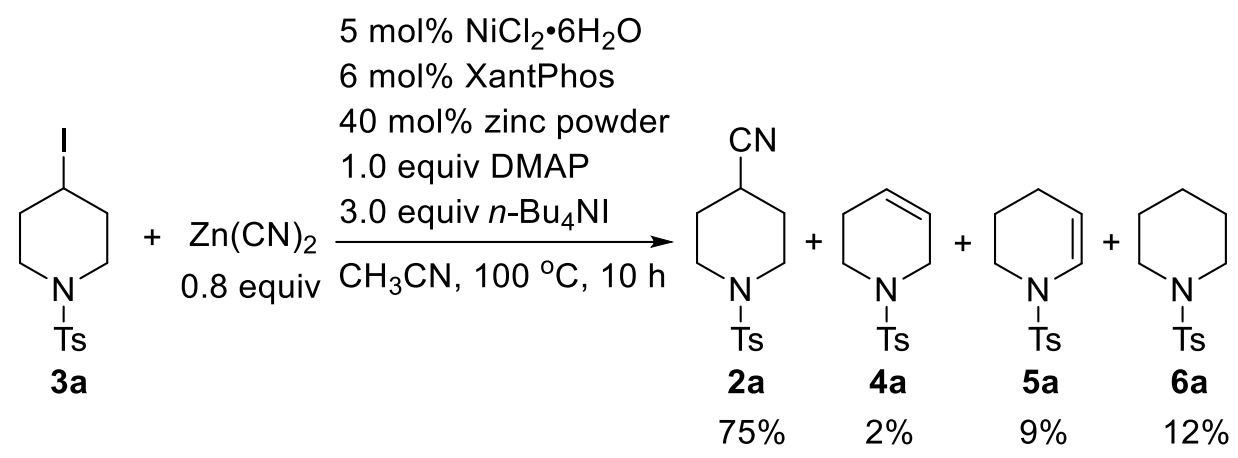

In a nitrogen-filled glove box, $\mathrm{NiCl}_{2} \cdot 6 \mathrm{H}_{2} \mathrm{O}(4.8 \mathrm{mg}, 0.02 \mathrm{mmol})$, DMAP (48.9 mg, 0.4 $\mathrm{mmol}), \mathrm{Zn}(\mathrm{CN})_{2}$ (37.6 mg, $\left.0.32 \mathrm{mmol}\right)$, zinc powder (10.5 mg, $\left.0.16 \mathrm{mmol}\right), n$-Bu $4 \mathrm{NI}(443.2$ mg, $1.2 \mathrm{mmol}$ ), XantPhos (13.9 mg, $0.024 \mathrm{mmol}), 3 \mathrm{a}(36.5 \mathrm{mg}, 0.1 \mathrm{mmol})$ and $\mathrm{CH}_{3} \mathrm{CN}(2.0$ $\mathrm{mL}$ ) were added sequentially to a $4 \mathrm{~mL}$ screw-cap vial. The vial was taken outside the glove box. After the reaction mixture was stirred at $100{ }^{\circ} \mathrm{C}$ (oil bath) for $2 \mathrm{~h}$, the mixture was cooled down. The vial was moved into glove box, and 0.1 mmol 3a was added. The vial was taken outside the glove box again and stirred at $100{ }^{\circ} \mathrm{C}$ for $2 \mathrm{~h}$. The above operation was repeated for next two times. After addition of the whole amounts of $\mathbf{3 a}$, the mixture was stirred for another 4 hours, then the mixture was filtered through a pad of silica gel and washed with $\mathrm{CH}_{2} \mathrm{Cl}_{2}$. The solvent was evaporated under the reduced pressure and the yield were determined by ${ }^{1} \mathrm{H}$ NMR using 1,3,5-trimethoxybenzene $(67.3 \mathrm{mg}, 0.4 \mathrm{mmol})$ as an internal standard, the NMR yield of 2a was $75 \%$, the NMR yield of $\mathbf{4 a}$ was $2 \%$, the NMR yield of $\mathbf{5 a}$ was $9 \%$ and the NMR yield of $6 \mathbf{a}$ was $12 \%$.

5) Reaction of $1 \mathrm{a}$ under the standard reaction conditions for $1 \mathrm{~h}$

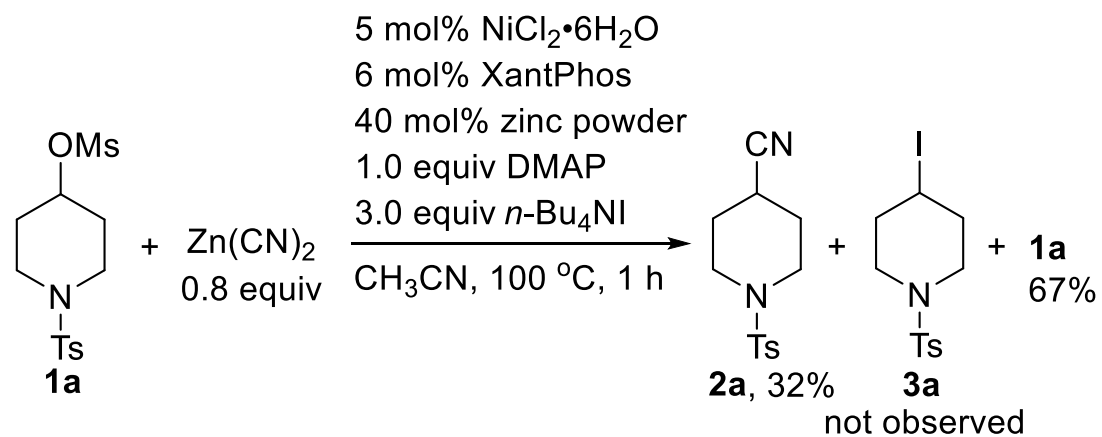


In a nitrogen-filled glove box, $\mathrm{NiCl}_{2} \cdot 6 \mathrm{H}_{2} \mathrm{O}(4.8 \mathrm{mg}, 0.02 \mathrm{mmol})$, DMAP (48.9 mg, 0.4 $\mathrm{mmol}), \mathrm{Zn}(\mathrm{CN})_{2}(37.6 \mathrm{mg}, 0.32 \mathrm{mmol})$, zinc powder (10.5 mg, $\left.0.16 \mathrm{mmol}\right), n-\mathrm{Bu} 4 \mathrm{NI}(443.2$ mg, $1.2 \mathrm{mmol}$ ), XantPhos (13.9 mg, $0.024 \mathrm{mmol}), 1 \mathrm{a}(133.4 \mathrm{mg}, 0.4 \mathrm{mmol})$ and $\mathrm{CH}_{3} \mathrm{CN}(2.0$ $\mathrm{mL}$ ) were added sequentially to a $4 \mathrm{~mL}$ screw-cap vial. The vial cap was then securely fitted and taken outside the glove box. After the reaction mixture was stirred at $100{ }^{\circ} \mathrm{C}$ (oil bath) for $1 \mathrm{~h}$, the mixture was cooled down, filtered through a pad of silica gel and washed with $\mathrm{CH}_{2} \mathrm{Cl}_{2}$. The solvent was evaporated under the reduced pressure and the yield were determined by ${ }^{1} \mathrm{H}$ NMR using 1,3,5-trimethoxybenzene $(67.3 \mathrm{mg}, 0.4 \mathrm{mmol})$ as an internal standard. The NMR yield of desired product (2a) was 32\%, the NMR yield of $\mathbf{1 a}$ was $67 \%$ and alkyl iodide (3a) was not observed.

6) Reaction of $1 \mathrm{a}$ with $\mathrm{Zn}(\mathrm{CN})_{2}$ in the presence of radical scavengers

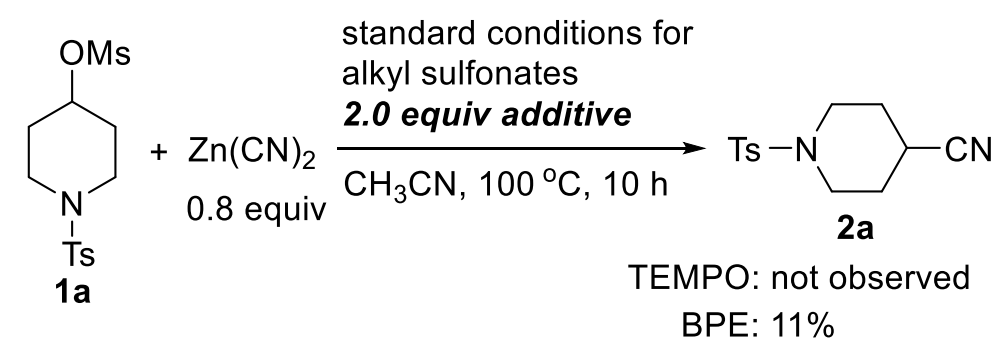

In a nitrogen-filled glove box, $\mathrm{NiCl}_{2} \cdot 6 \mathrm{H}_{2} \mathrm{O}(4.8 \mathrm{mg}, 0.02 \mathrm{mmol})$, DMAP (48.9 mg, 0.4 $\mathrm{mmol}), \mathrm{Zn}(\mathrm{CN})_{2}(37.6 \mathrm{mg}, 0.32 \mathrm{mmol})$, zinc powder (10.5 mg, $\left.0.16 \mathrm{mmol}\right), n-\mathrm{Bu} 4 \mathrm{NI}(443.2$ mg, $1.2 \mathrm{mmol}$ ), XantPhos (13.9 mg, $0.024 \mathrm{mmol}), 1 \mathrm{a}(133.4 \mathrm{mg}, 0.4 \mathrm{mmol})$, radical scavenger and $\mathrm{CH}_{3} \mathrm{CN}(2.0 \mathrm{~mL})$ were added sequentially to a $4 \mathrm{~mL}$ screw-cap vial. The vial cap was then securely fitted and taken outside the glove box. After the reaction mixture was stirred at 100 ${ }^{\circ} \mathrm{C}$ (oil bath) for $10 \mathrm{~h}$, the mixture was filtered through a pad of silica gel and washed with $\mathrm{CH}_{2} \mathrm{Cl}_{2}$. The solvent was evaporated under the reduced pressure.

When TEMPO (125.0 mg, $0.8 \mathrm{mmol}$ ) was used as the radical scavenger, no desired product (2a) was observed.

When BPE (1,1-diphenylethylene) (144.2 $\mathrm{mg}, 0.8 \mathrm{mmol})$ was used as the radical scavenger, 2a could be observed in 11\% NMR yield with 1,3,5-trimethoxybenzene (67.3 mg, $0.4 \mathrm{mmol}$ ) as an internal standard. 


\section{Reference:}

(1) Soulard, V.; Villa, G.; Vollmar, D. P.; Renaud, P. Radical Deuteration with $\mathrm{D}_{2} \mathrm{O}$ : Catalysis and Mechanistic Insights. J. Am. Chem. Soc. 2018, 140, 155.

(2) Weng, W.-Z.; Liang, H.; Zhang, B. Visible-Light-Mediated Aerobic Oxidation of Organoboron Compounds Using in Situ Generated Hydrogen Peroxide. Org. Lett. 2018, 20 , 4979.

(3) Anthore, L.; Zard, S. Z. A Convergent Radical Based Route to Trifluoromethyl Ketones and to $\alpha, \beta$-Unsaturated Trifluoromethyl Ketones. Org. Lett. 2015, 17, 3058.

(4) Sun, Q.; Cai, S.; Peterson, B. R. Practical Synthesis of 3 $\beta$-Amino-5-cholestene and Related $3 \beta$-Halides Involving $i$-Steroid and Retro- $i$-Steroid Rearrangements. Org. Lett. 2009, 11, 567.

(5) Liu, Y.; Cornella, J.; Martin, R. Ni-Catalyzed Carboxylation of Unactivated Primary Alkyl Bromides and Sulfonates with $\mathrm{CO}_{2}$. J. Am. Chem. Soc. 2014, 136, 11212.

(6) Kim, D. W.; Jeong, H.-J.; Lim, S. T.; Sohn, M.-H. Tetrabutylammonium Tetra(tert-Butyl Alcohol)-Coordinated Fluoride as a Facile Fluoride Source. Angew. Chem. Int. Ed. 2008, $47,8404$.

(7) Romeiro, L. A. S.; da Silva Ferreira, M.; da Silva, L. L.; Castro, H. C.; Miranda, A. L. P.; Silva, C. L. M.; Noël, F.; Nascimento, J. B.; Araújo, C. V.; Tibiricá, E.; Barreiro, E. J.; Fraga, C. A. M. Discovery of LASSBio-772, a 1,3-benzodioxole $N$-phenylpiperazine derivative with potent alpha $1 \mathrm{~A} / \mathrm{D}$-adrenergic receptor blocking properties. Eur. J. Med. Chem. 2011, 46, 3000.

(8) Cho, W. S.; Kim, S. H.; Kim, D. J.; Mun, S.-d.; Kim, R.; Go, M. J.; Park, M. H.; Kim, M.; Lee, J.; Kim, Y. Zirconium complexes with pendant aryloxy groups attached to the metallocene moiety by ethyl or hexyl spacers. Polyhedron 2014, 67, 205.

(9) Xia, A.; Xie, X.; Chen, H.; Zhao, J.; Zhang, C.; Liu, Y. Nickel-Catalyzed Cyanation of Unactivated Alkyl Chlorides or Bromides with $\mathrm{Zn}(\mathrm{CN})_{2}$. Org. Lett. 2018, 20, 7735.

(10) Ramirez, N. P.; König, B.; Gonzalez-Gomez, J. C. Decarboxylative Cyanation of Aliphatic Carboxylic Acids via Visible-Light Flavin Photocatalysis. Org. Lett. 2019, 21, 1368. 
(11) Alazet, S.; West, M. S.; Patel, P.; Rousseaux, S. A. L. Synthesis of Nitrile-Bearing Quaternary Centers by an Equilibrium-Driven Transnitrilation and Anion-Relay Strategy. Angew. Chem. Int. Ed. 2019, 58, 10300.

(12) Rong, G.; Liu, D.; Lu, L.; Yan, H.; Zheng, Y.; Chen, J.; Mao, J. Iron-catalyzed decarboxylative methylation of $\alpha, \beta$-unsaturated acids under ligand-free conditions. Tetrahedron 2014, 70, 5033.

(13) Dreher, S. D.; Lim, S.-E.; Sandrock, D. L.; Molander, G. A. Suzuki-Miyaura CrossCoupling Reactions of Primary Alkyltrifluoroborates with Aryl Chlorides. J. Org. Chem. 2009, 74, 3626.

(14) Iwata, Y.; Tanaka, Y.; Kubosaki, S.; Morita, T.; Yoshimi, Y. A strategy for generating aryl radicals from arylborates through organic photoredox catalysis: photo-Meerwein type arylation of electron-deficient alkenes. Chem. Commun. 2018, 54, 1257.

(15) Tanji, Y.; Hamaguchi, R.; Tsuji, Y.; Fujihara, T. Pd-Catalyzed intermolecular C-H bond arylation reactions: effect of bulkiness of carboxylate ligands. Chem. Commun. 2020, 56, 3843.

(16) Winkler, M.; Meischler, D.; Klempier, N. Nitrilase-Catalyzed Enantioselective Synthesis of Pyrrolidine- and Piperidinecarboxylic Acids. Adv. Synth. Catal. 2007, 349, 1475. 
${ }^{1}$ H NMR (400 MHz, CDCl3)

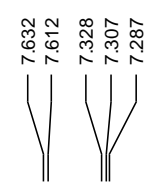

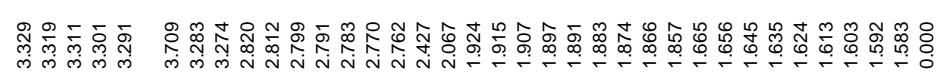

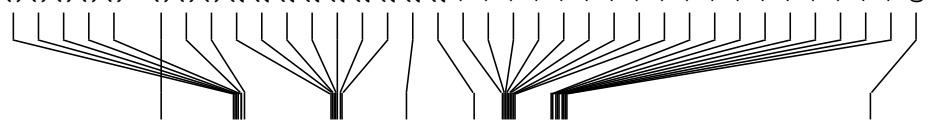

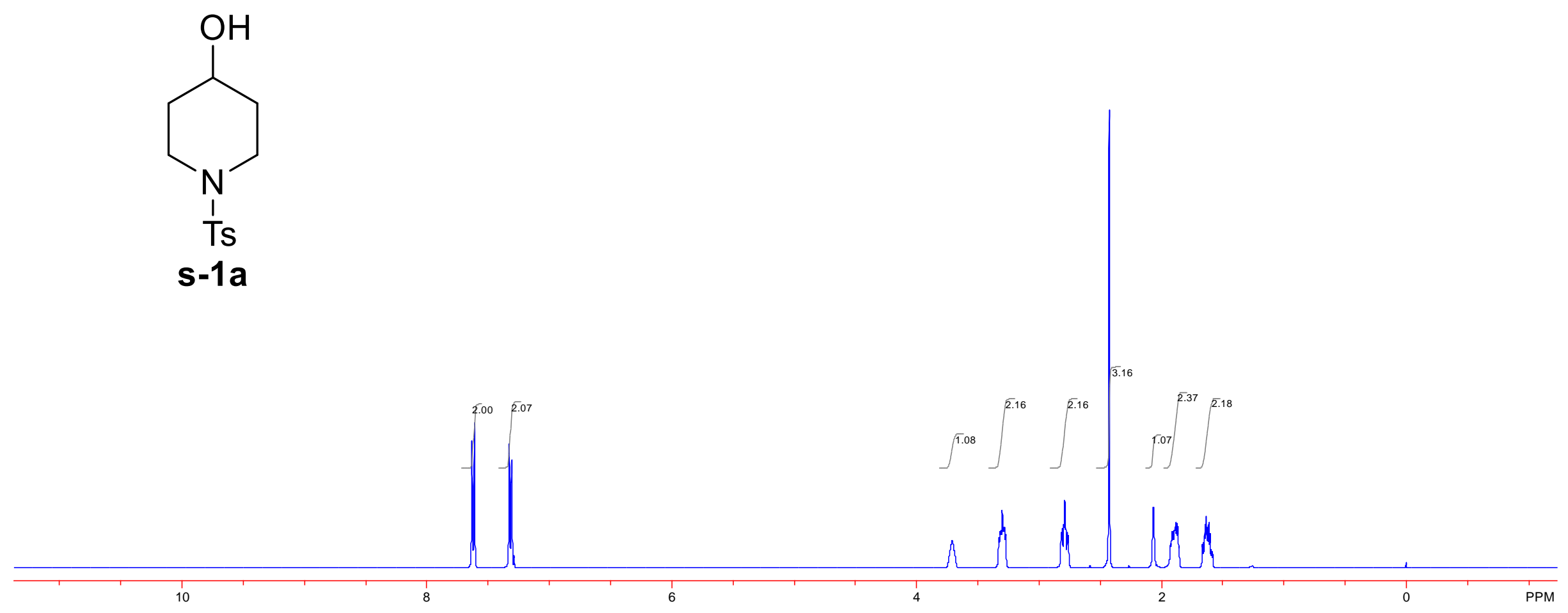


${ }^{13} \mathrm{C}$ NMR (100 MHz, CDCl3)
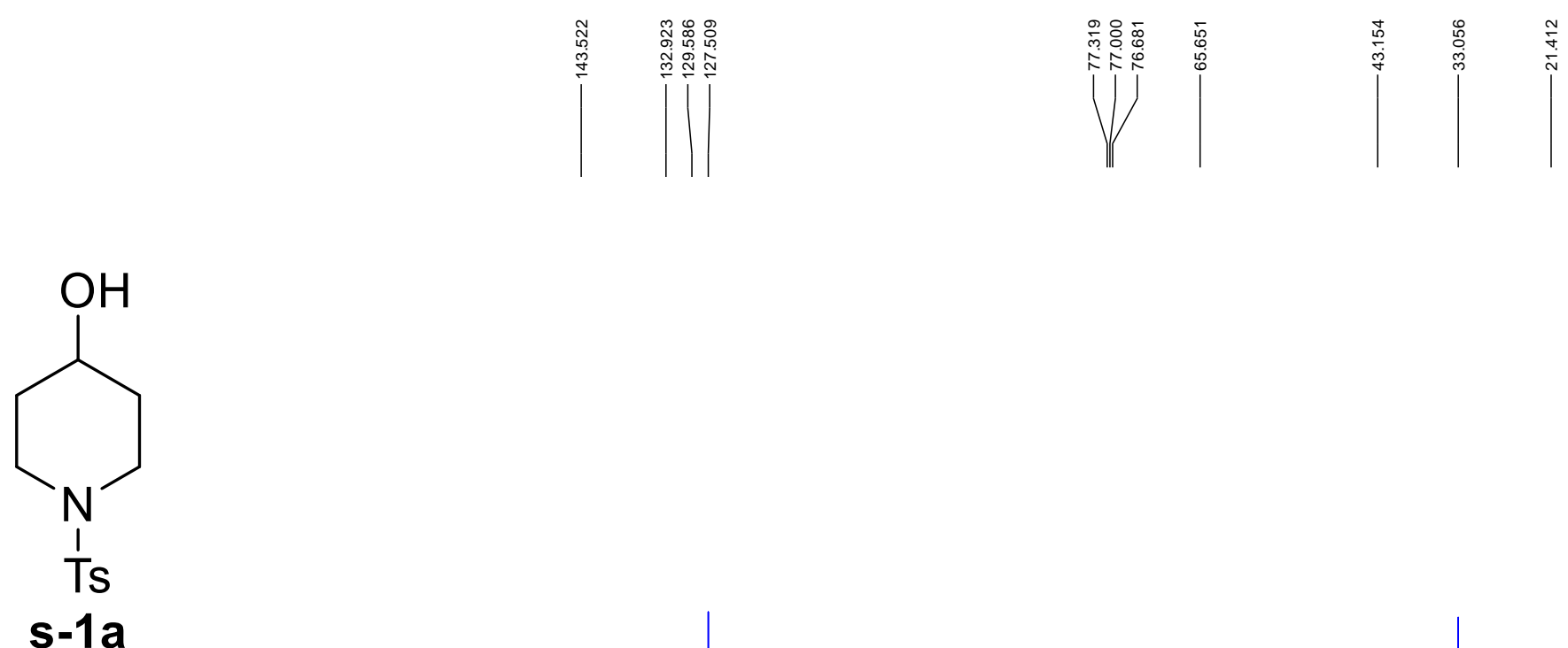
${ }^{1}$ H NMR (400 MHz, CDCl3)
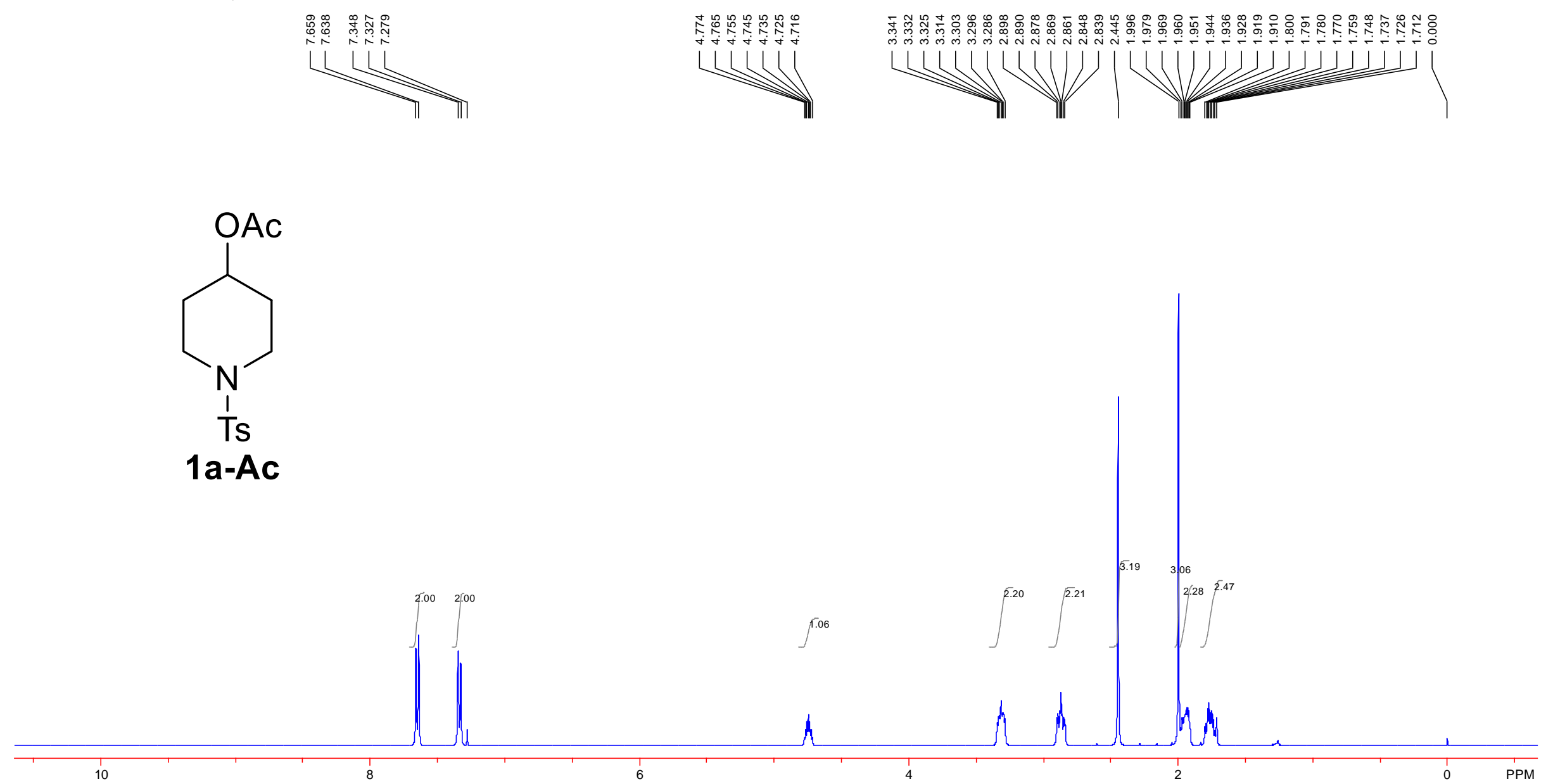
${ }^{13} \mathrm{C}$ NMR (100 MHz, CDCl3)
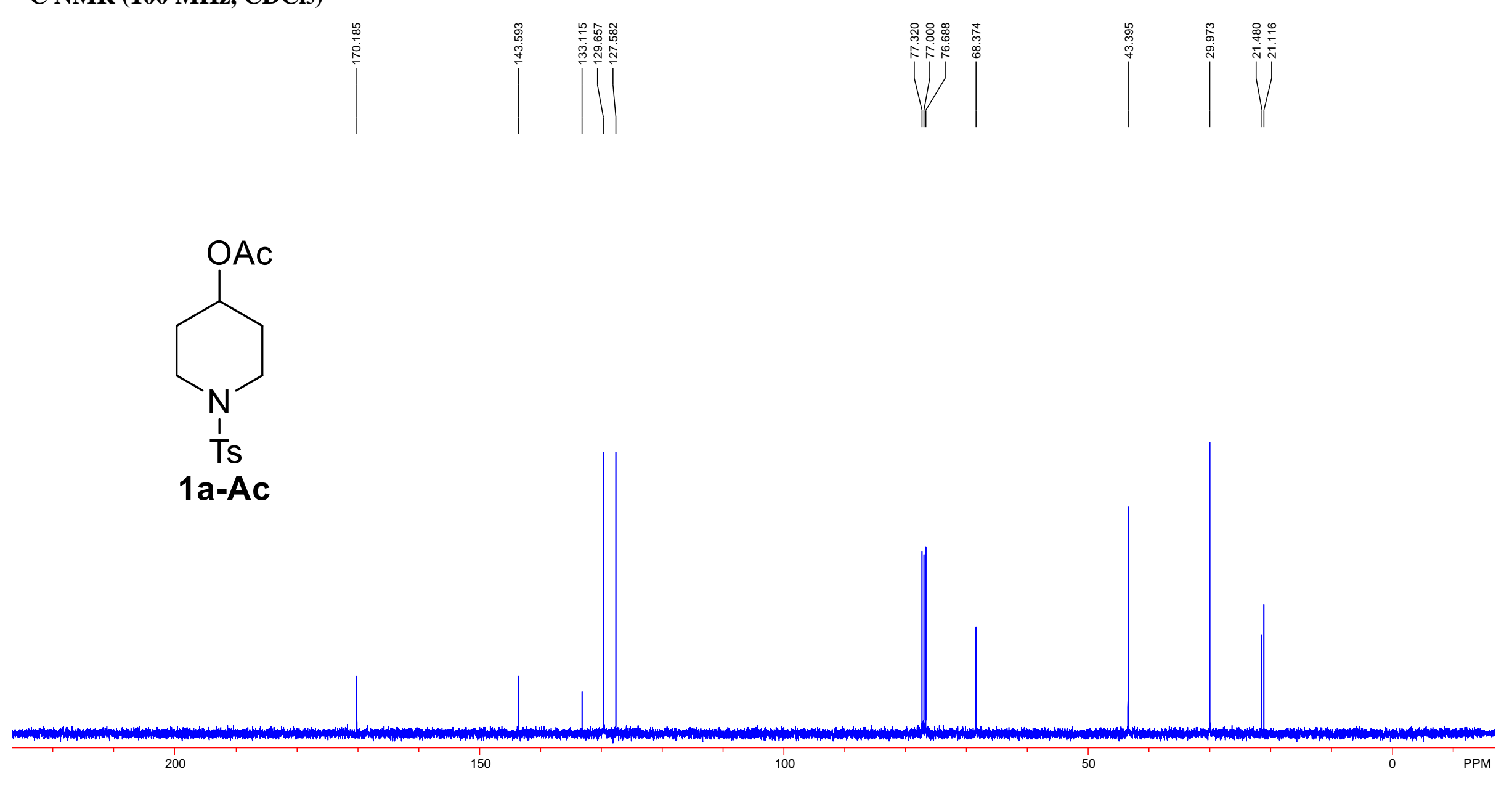
${ }^{1} \mathrm{H}$ NMR (400 MHz, CDCl3)

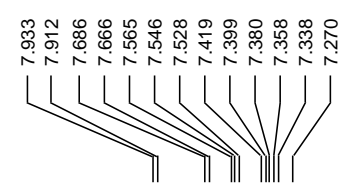

Oa-Bz

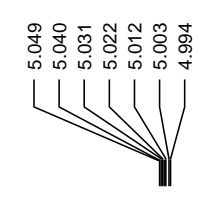

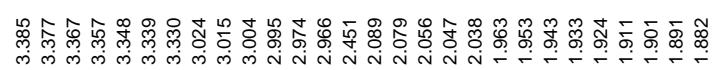

HWWUH UWHHWD

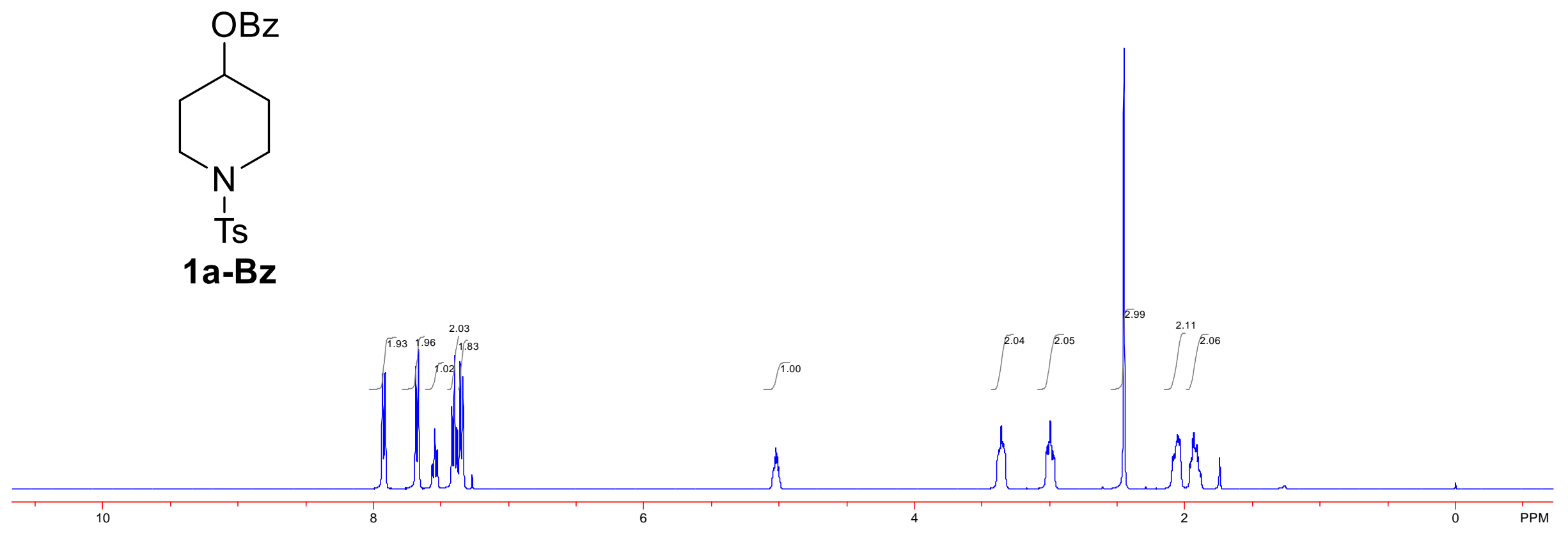


${ }^{13} \mathrm{C}$ NMR (100 MHz, CDCl3)
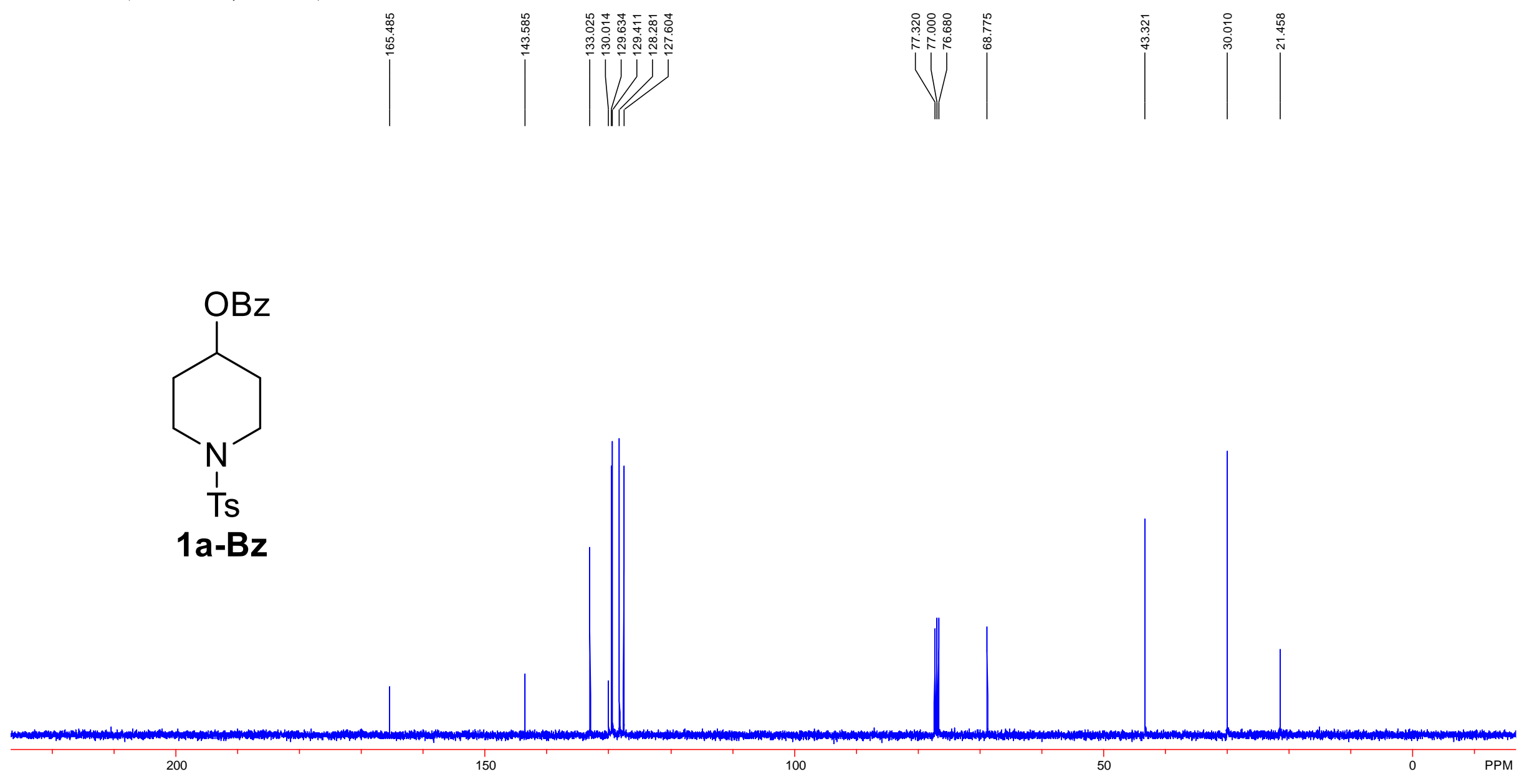
${ }^{1} \mathrm{H}$ NMR (400 MHz, CDCl3)
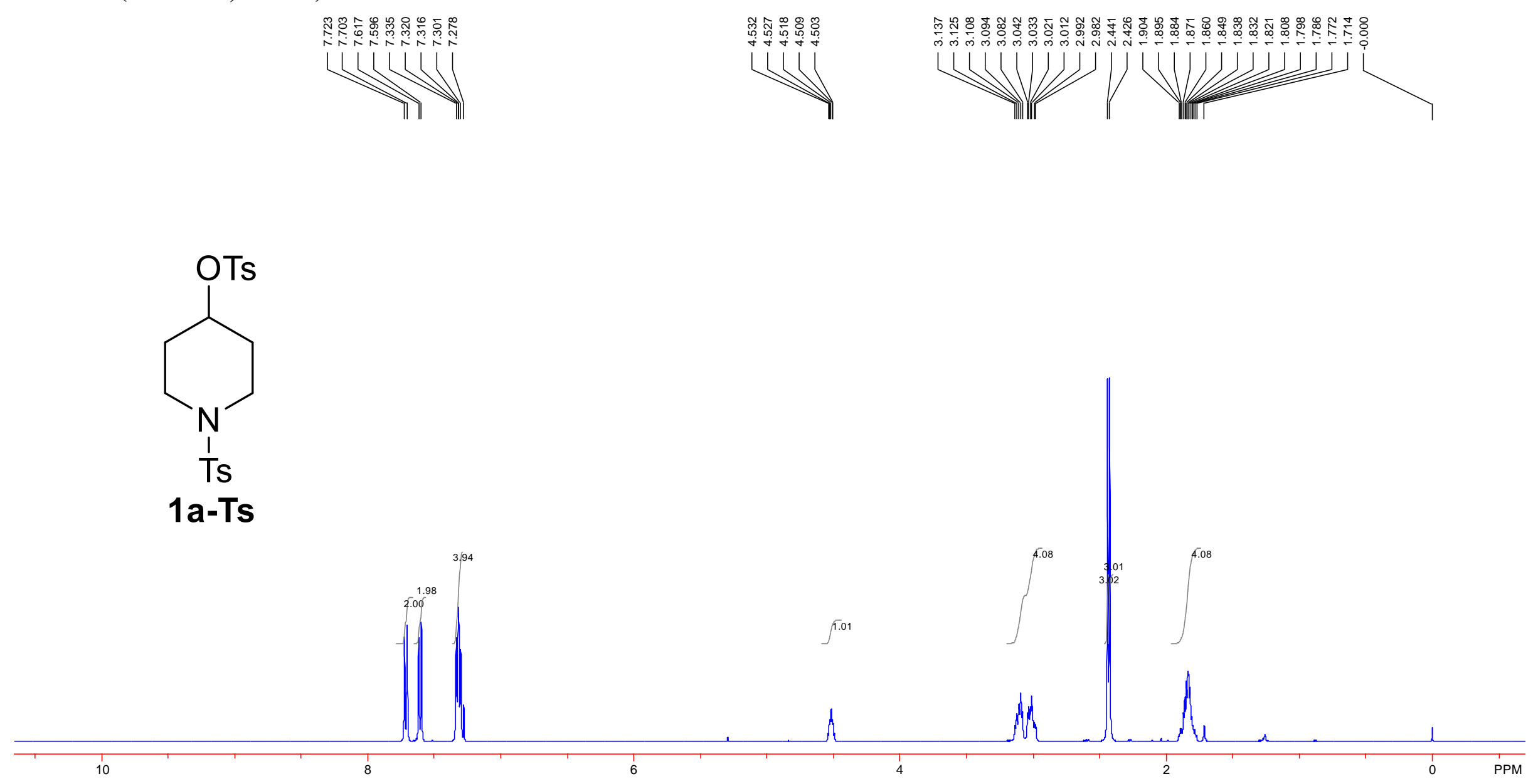
${ }^{13} \mathrm{C}$ NMR (100 MHz, CDCl3)
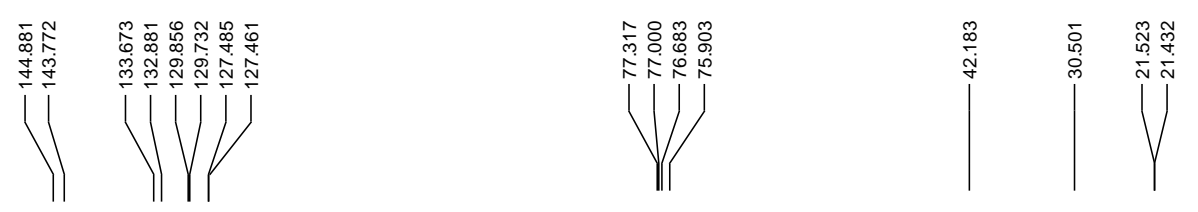

1a-Ts

250 
${ }^{1}$ H NMR (400 MHz, CDCl3)
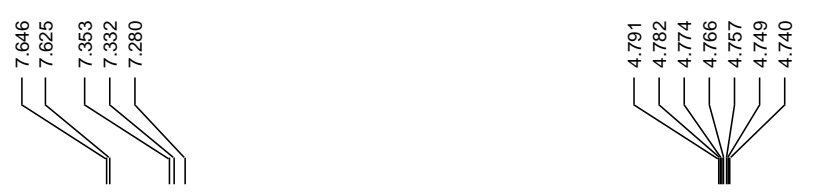

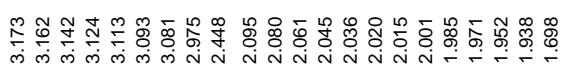
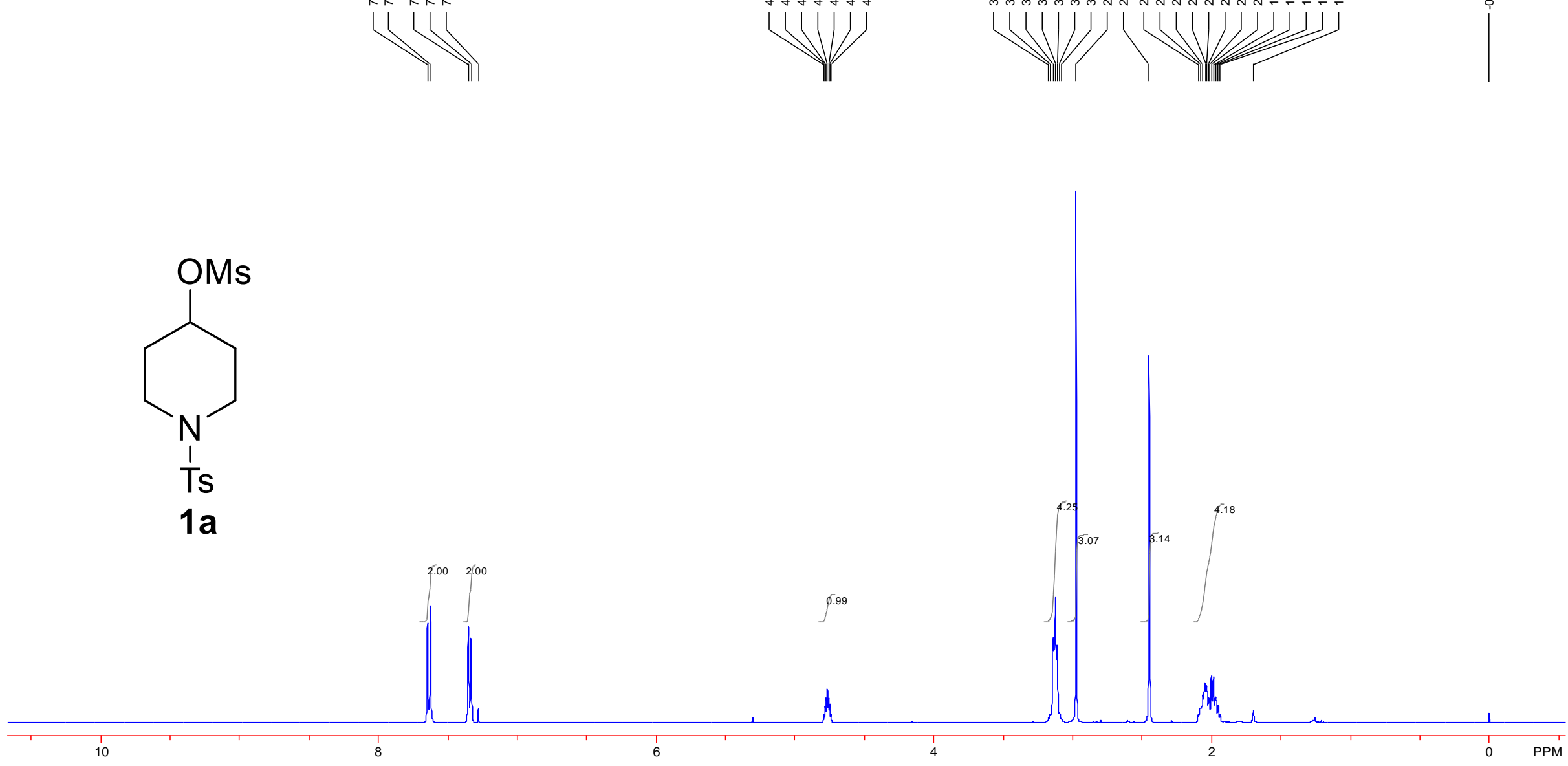
${ }^{13} \mathrm{C}$ NMR (100 MHz, CDCl3)
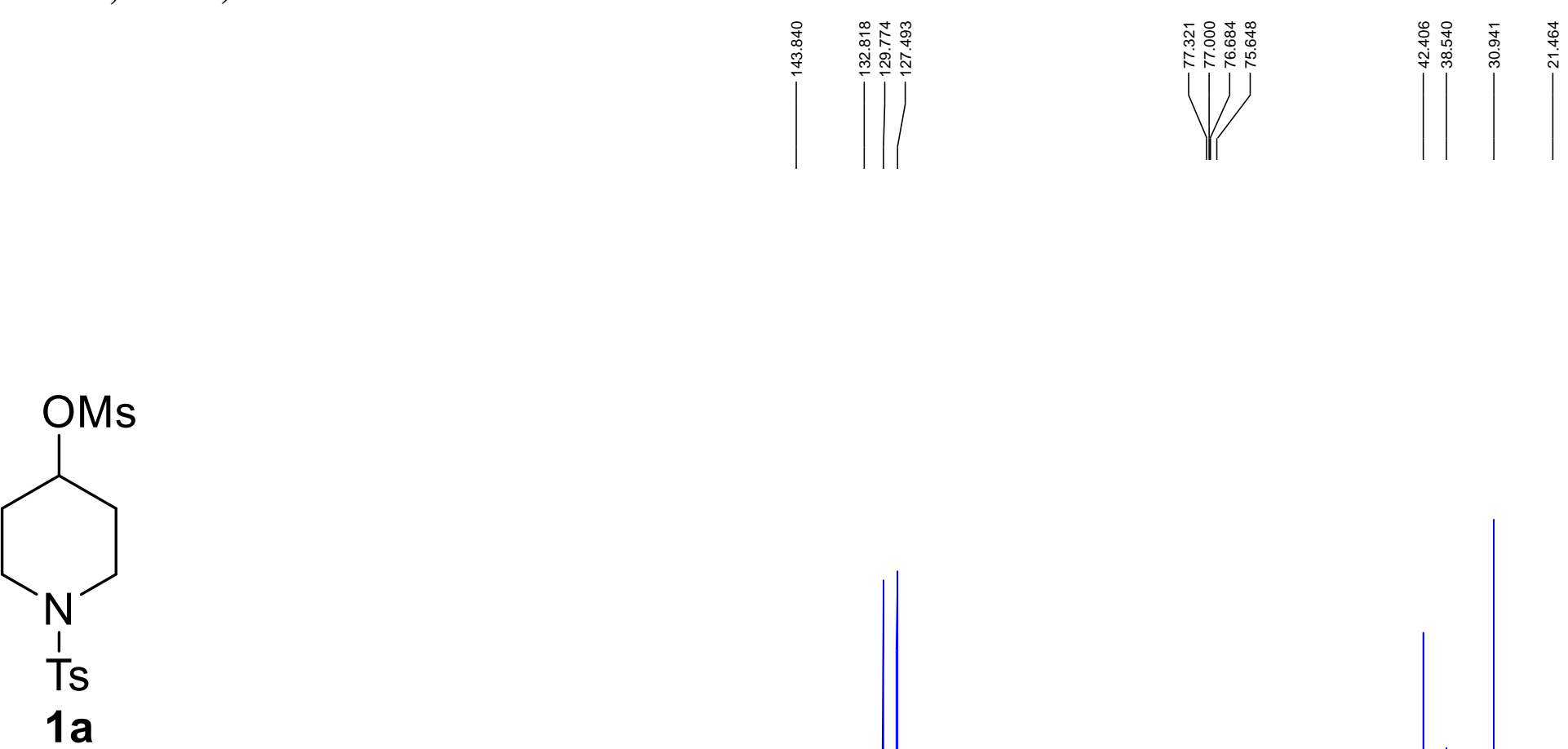
${ }^{1}$ H NMR (400 MHz, CDCl3)

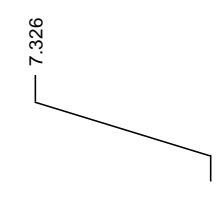

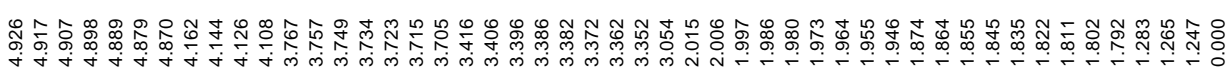
(n)<smiles>CCOC(=O)N1CCC(OC)CC1</smiles>

1c

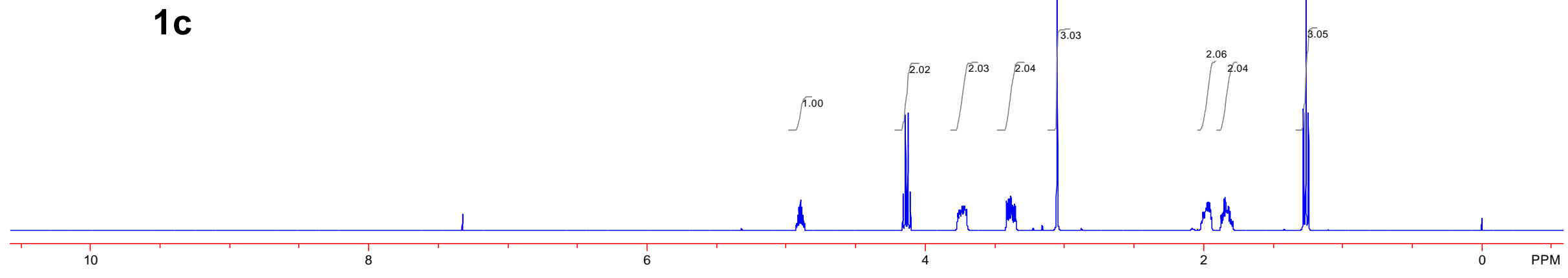


${ }^{13} \mathrm{C}$ NMR (100 MHz, CDCl3)

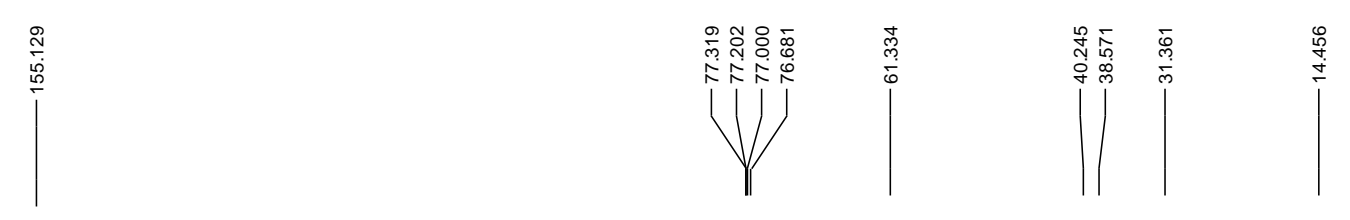<smiles>CCOC(=O)N1CCC(OC)CC1</smiles>

$1 \mathrm{c}$ 
${ }^{1}$ H NMR (400 MHz, CDCl3)
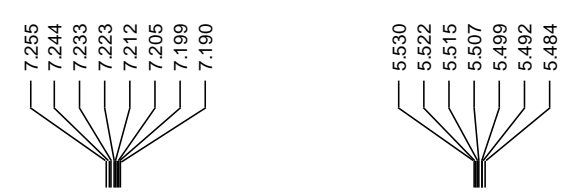

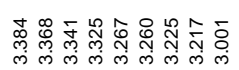

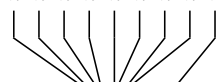

\section{$\stackrel{\leftrightarrow}{\circ}$}<smiles>COC1Cc2ccccc2C1</smiles>

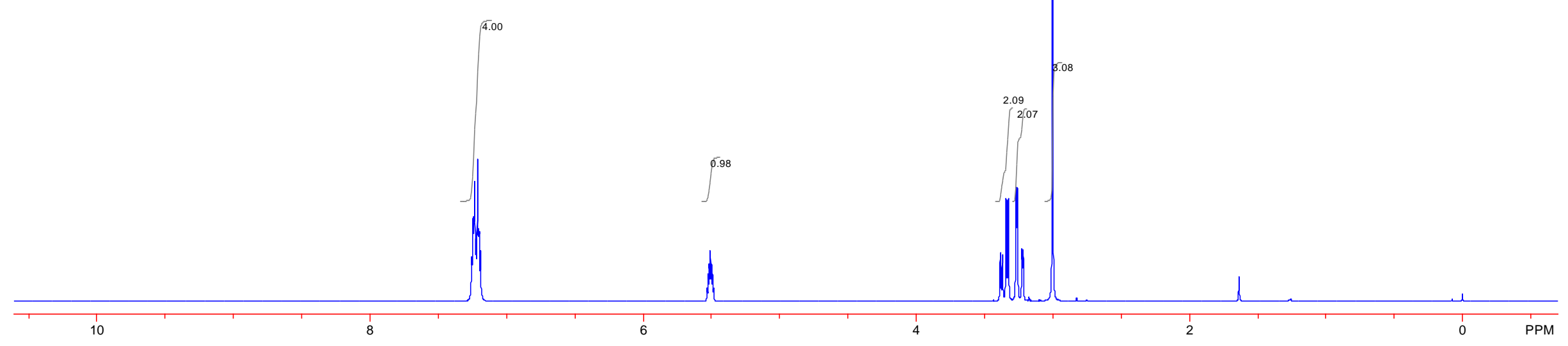


${ }^{13} \mathrm{C}$ NMR (100 MHz, CDCl3)
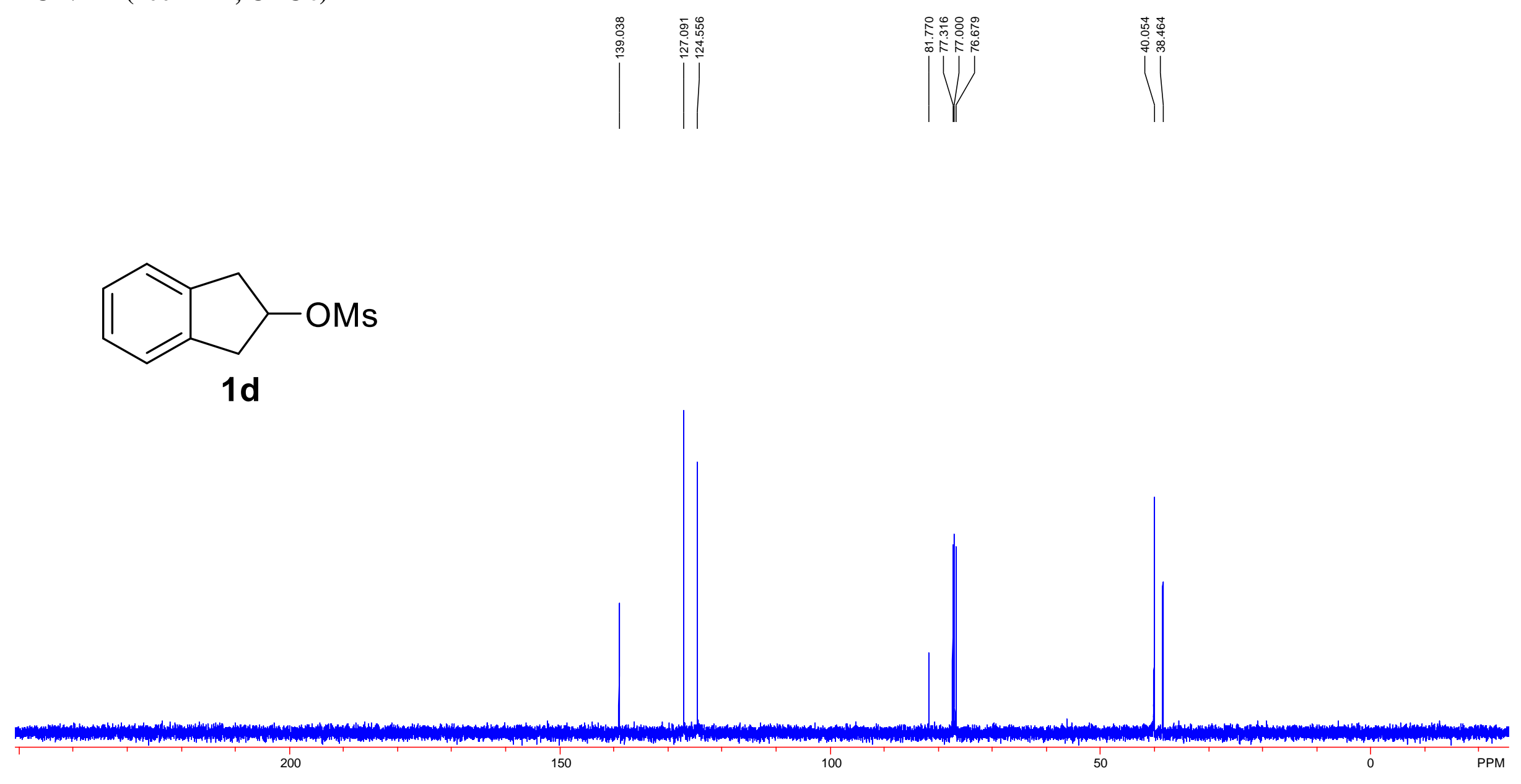
${ }^{1}$ H NMR (400 MHz, CDCl3)

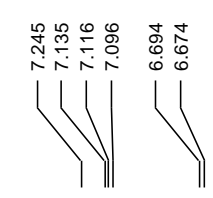

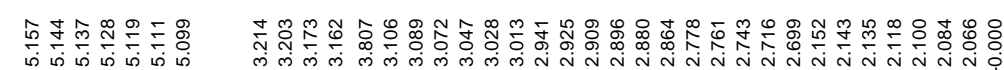

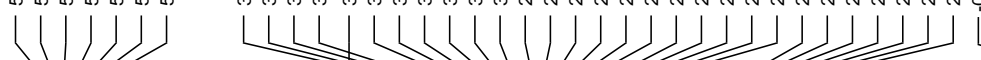

W

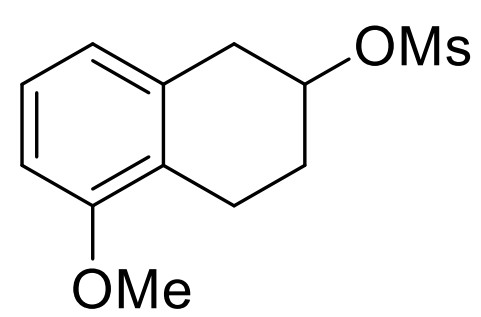

$1 e$

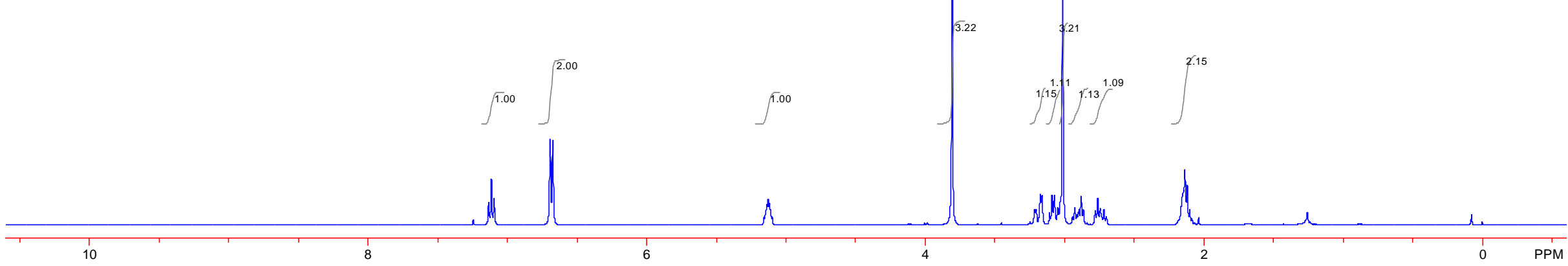


${ }^{13} \mathrm{C}$ NMR (100 MHz, CDCl3)
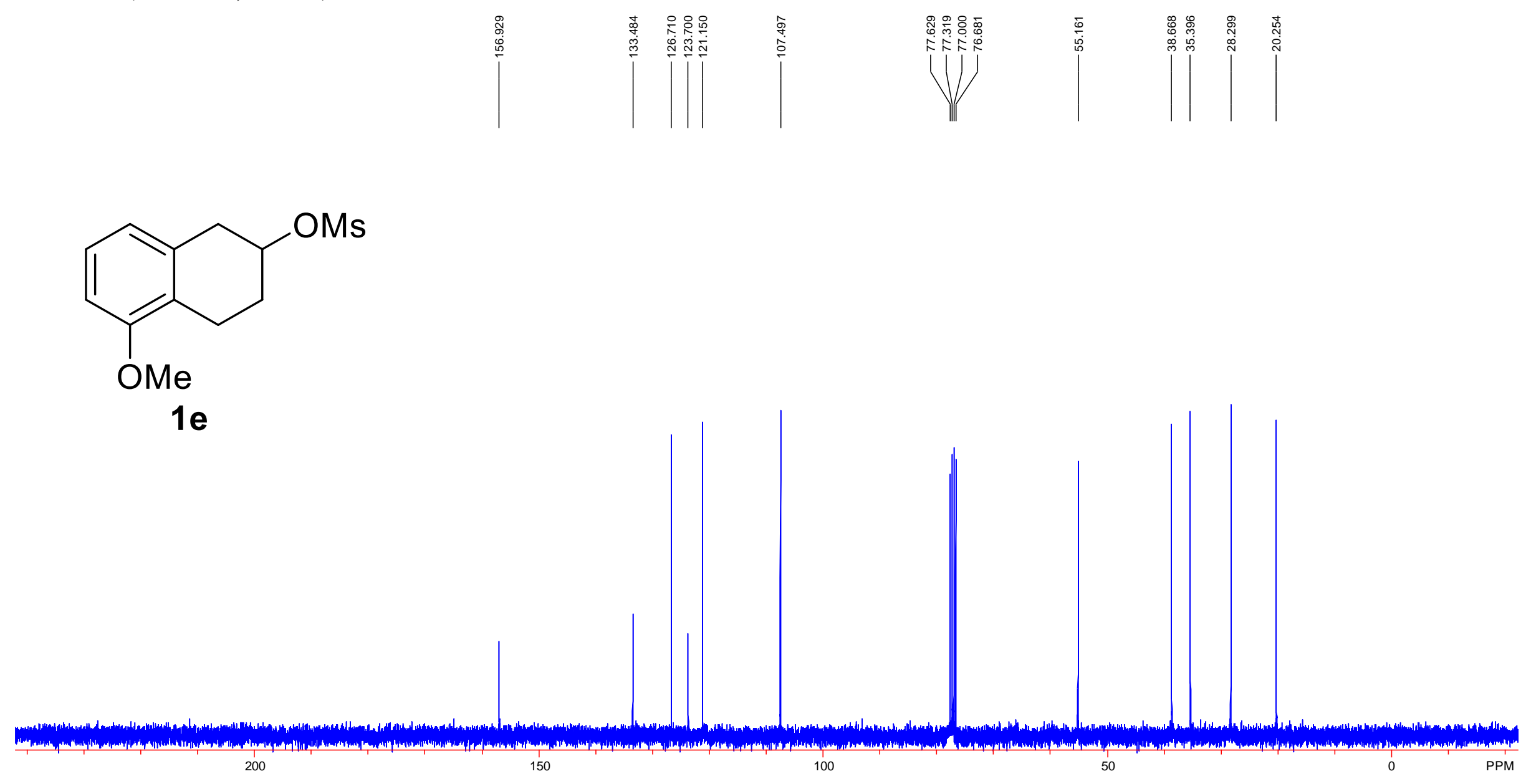
${ }^{1}$ H NMR (400 MHz, CDCl3)
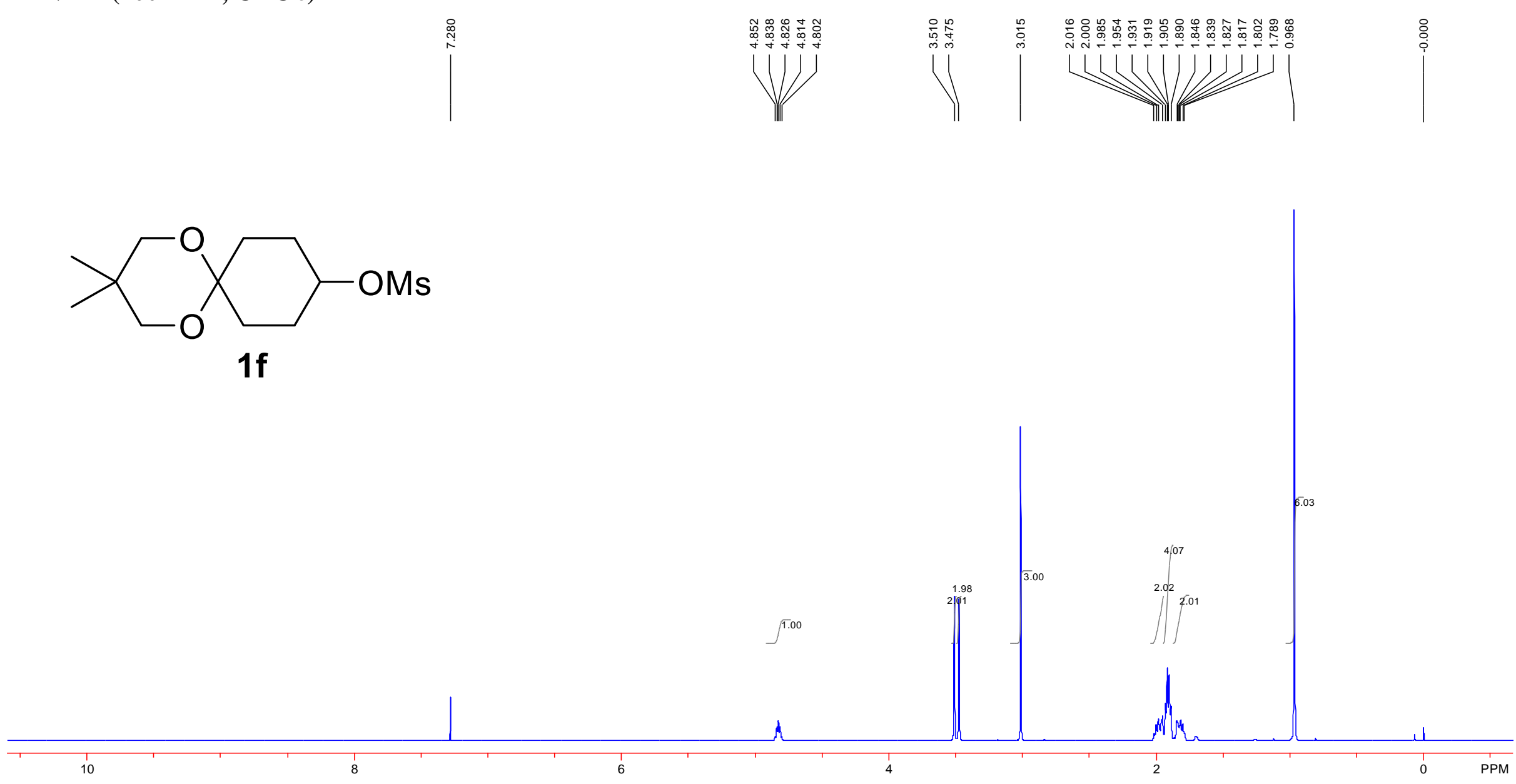
${ }^{13} \mathrm{C}$ NMR (100 MHz, CDCl3)
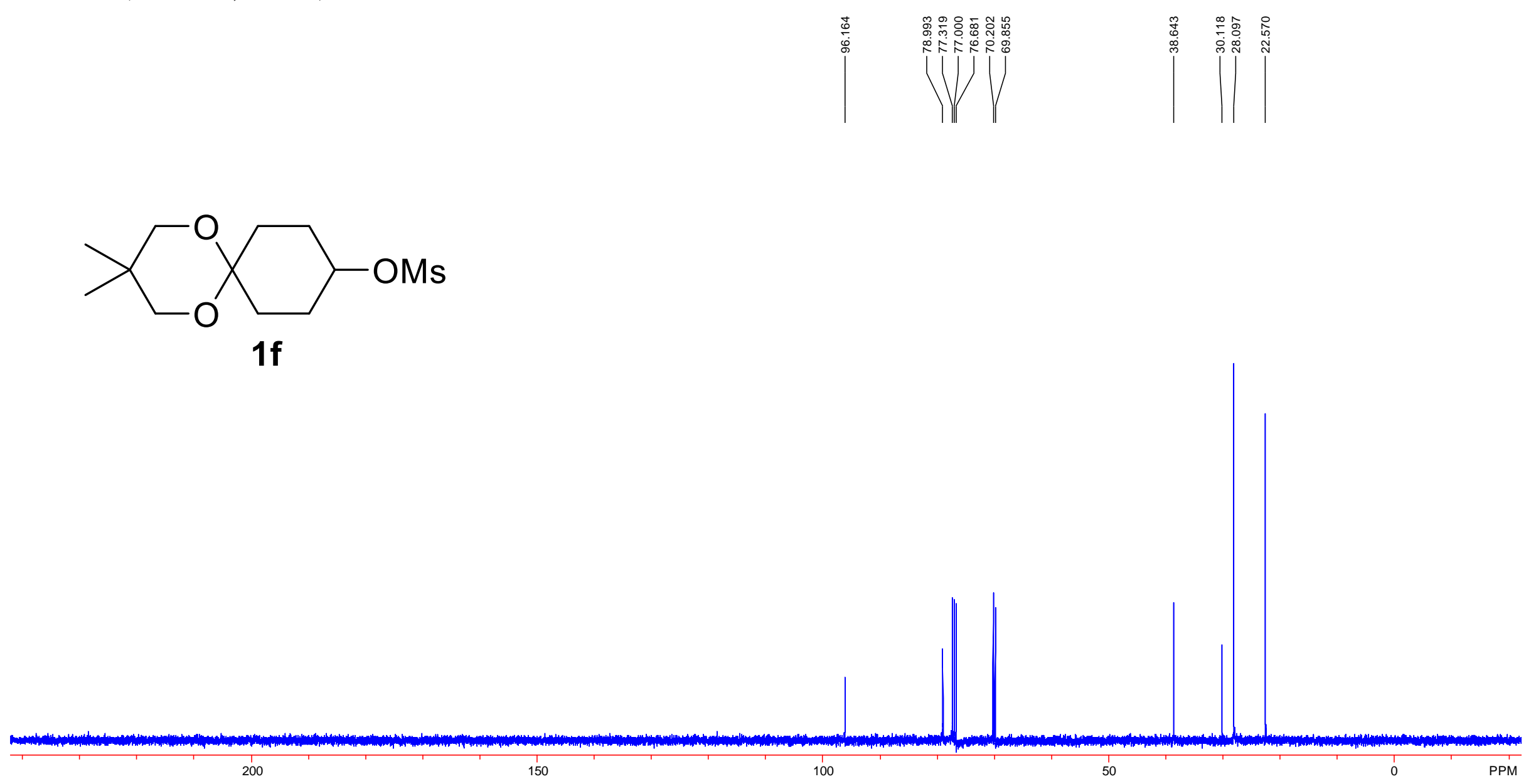
${ }^{1}$ H NMR (400 MHz, CDCl3)

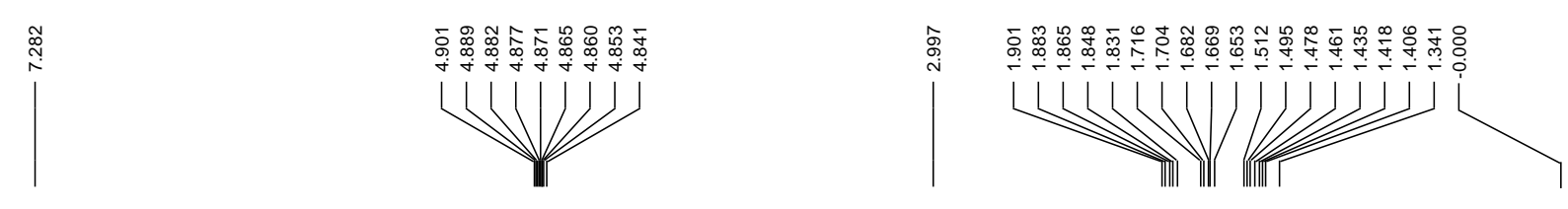<smiles>COC1CCCCCCCCCCC1</smiles>

$1 \mathrm{~g}$ 
${ }^{13} \mathrm{C}$ NMR (100 MHz, CDCl3)
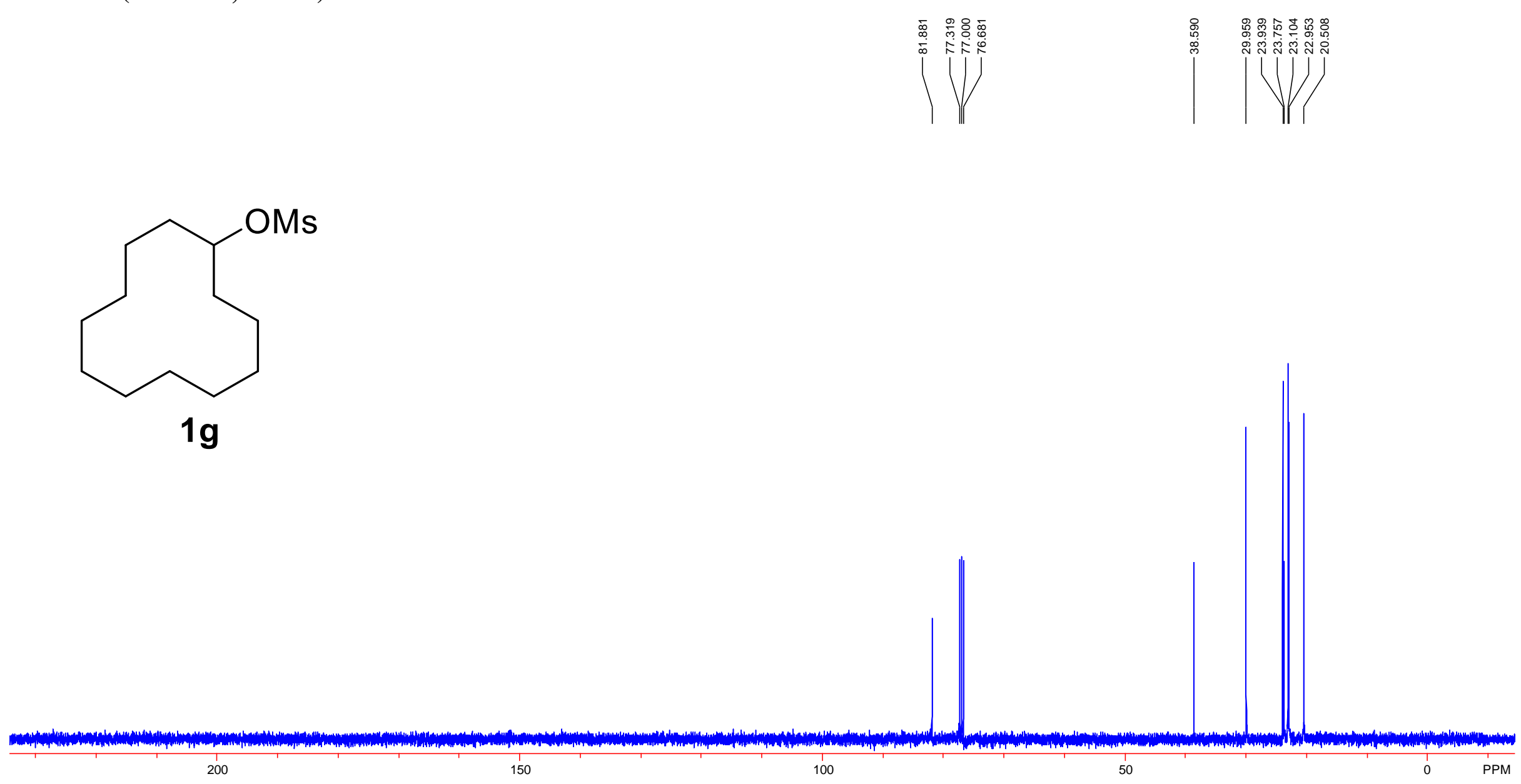
${ }^{1}$ H NMR (400 MHz, CDCl3)

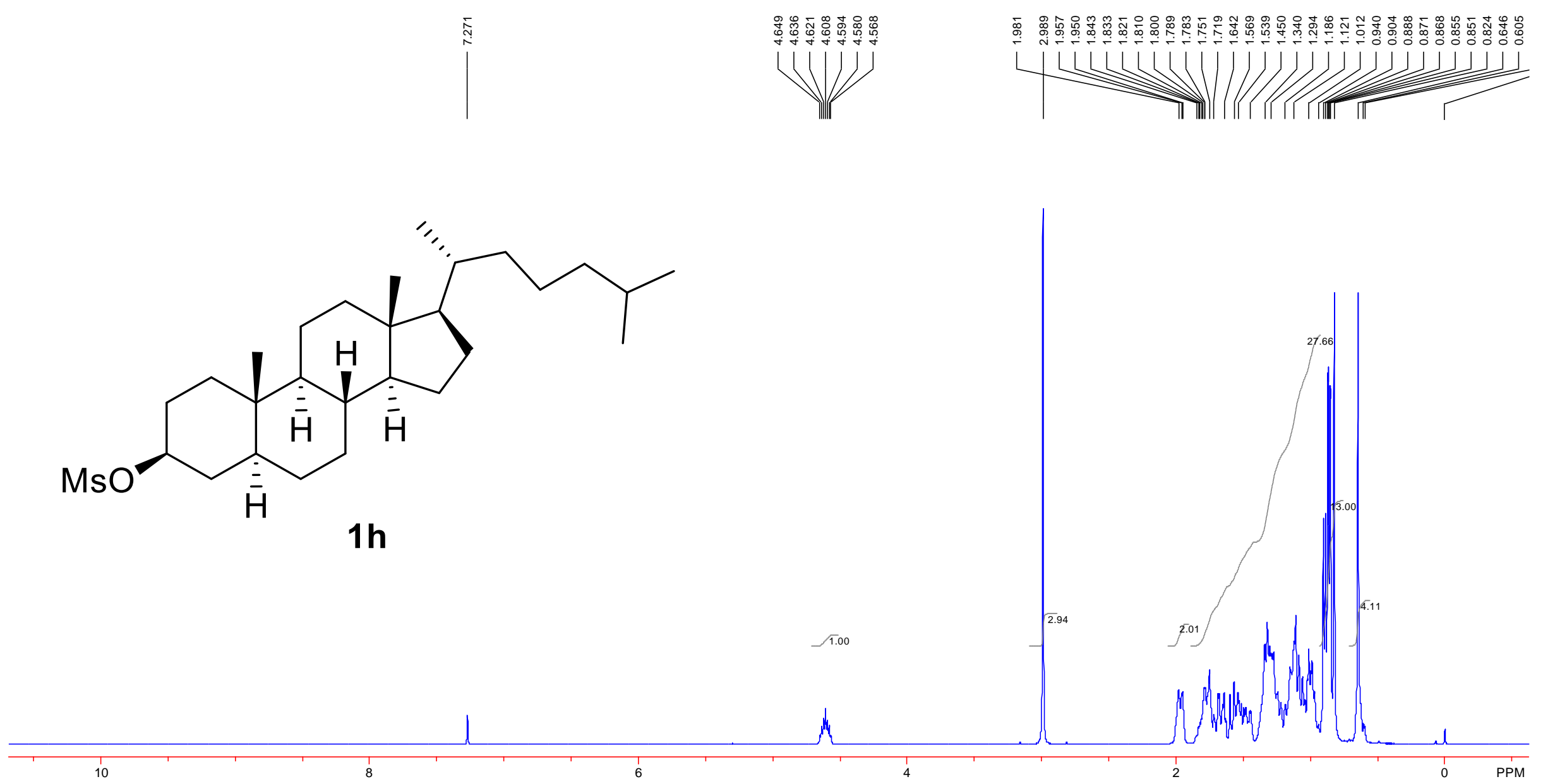


${ }^{13} \mathrm{C}$ NMR (100 MHz, CDCl3)
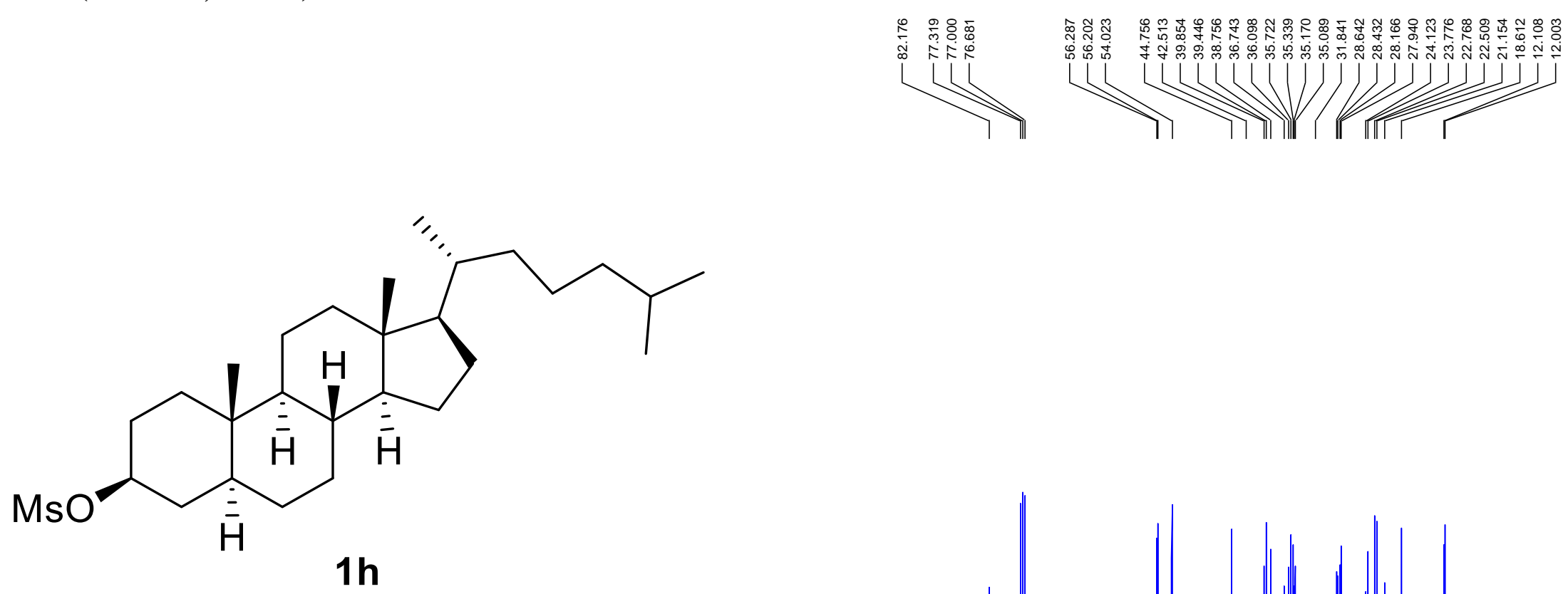
${ }^{1}$ H NMR (400 MHz, CDCl3)

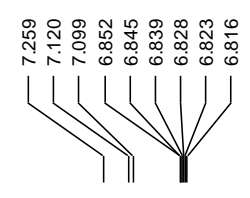

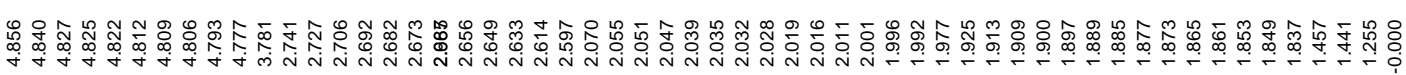

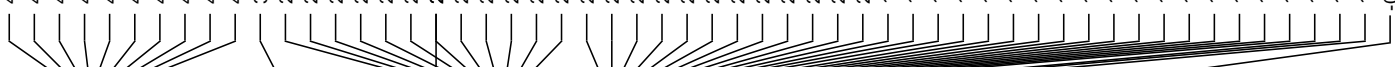<smiles>COc1ccc(CCC(C)OC)cc1</smiles>

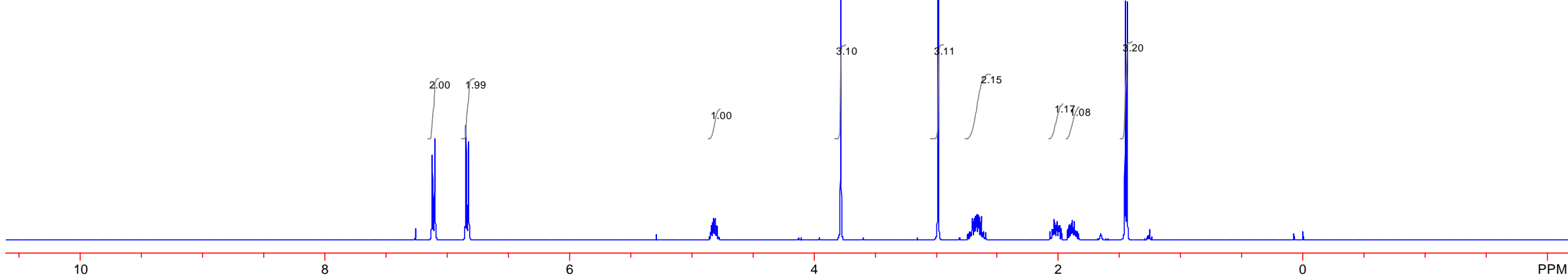


${ }^{13} \mathrm{C}$ NMR (100 MHz, CDCl3)
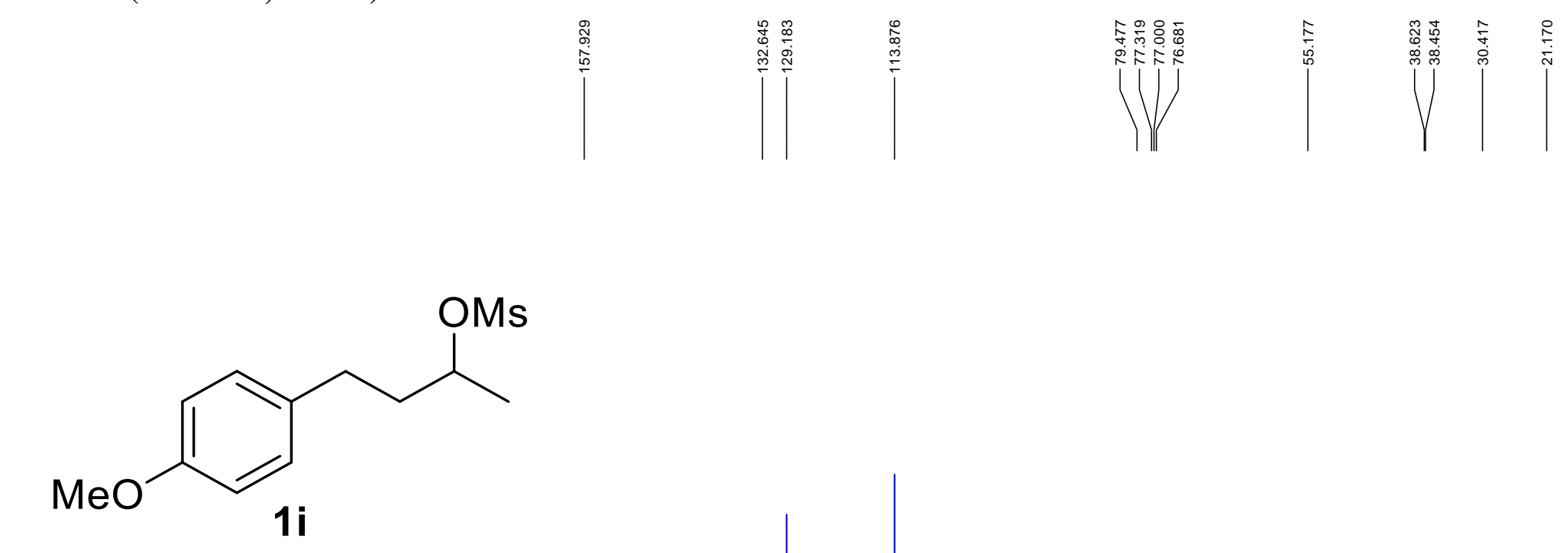

200 
${ }^{1}$ H NMR (400 MHz, CDCl3)
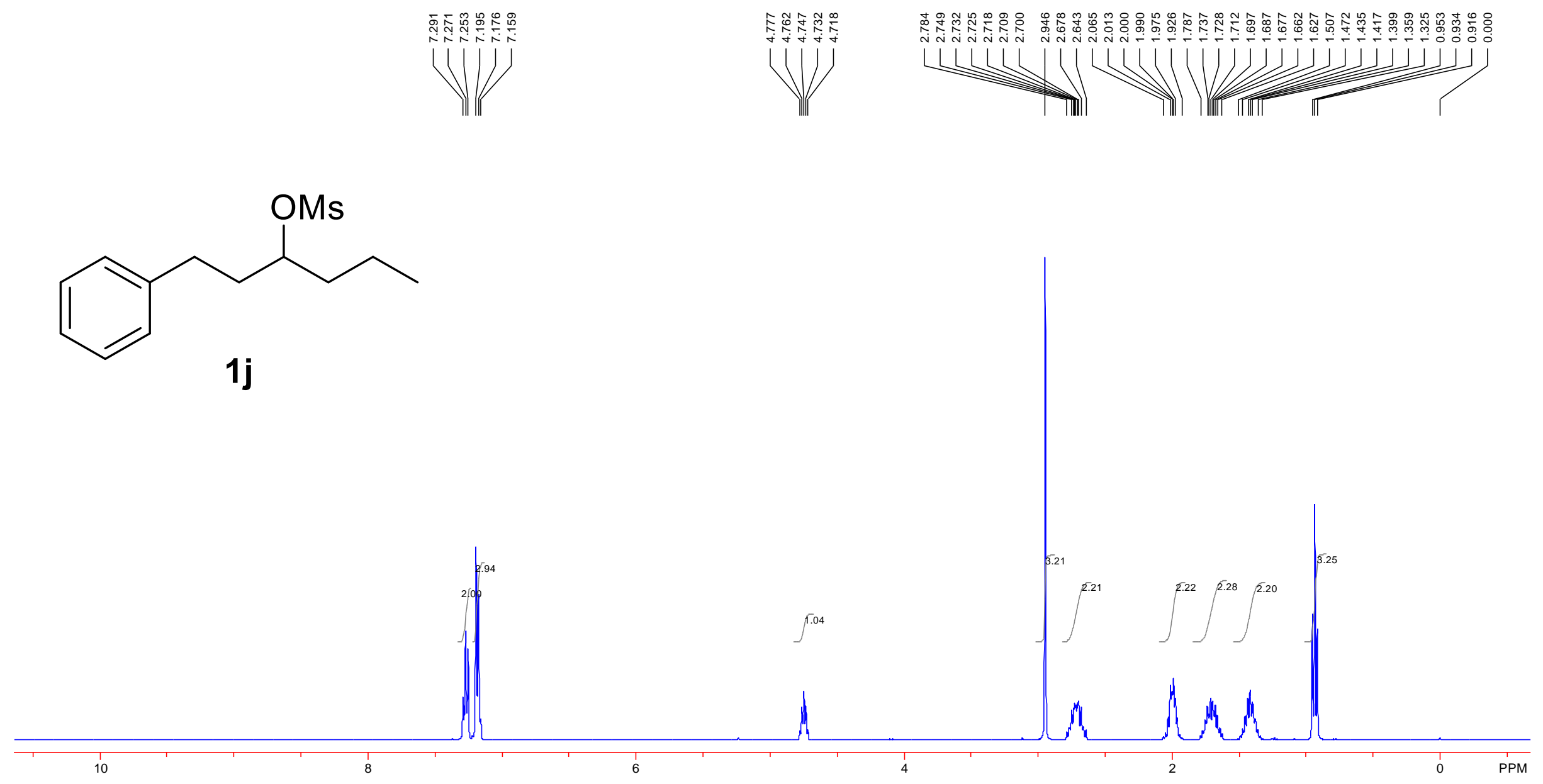
${ }^{13} \mathrm{C}$ NMR (100 MHz, CDCl3)
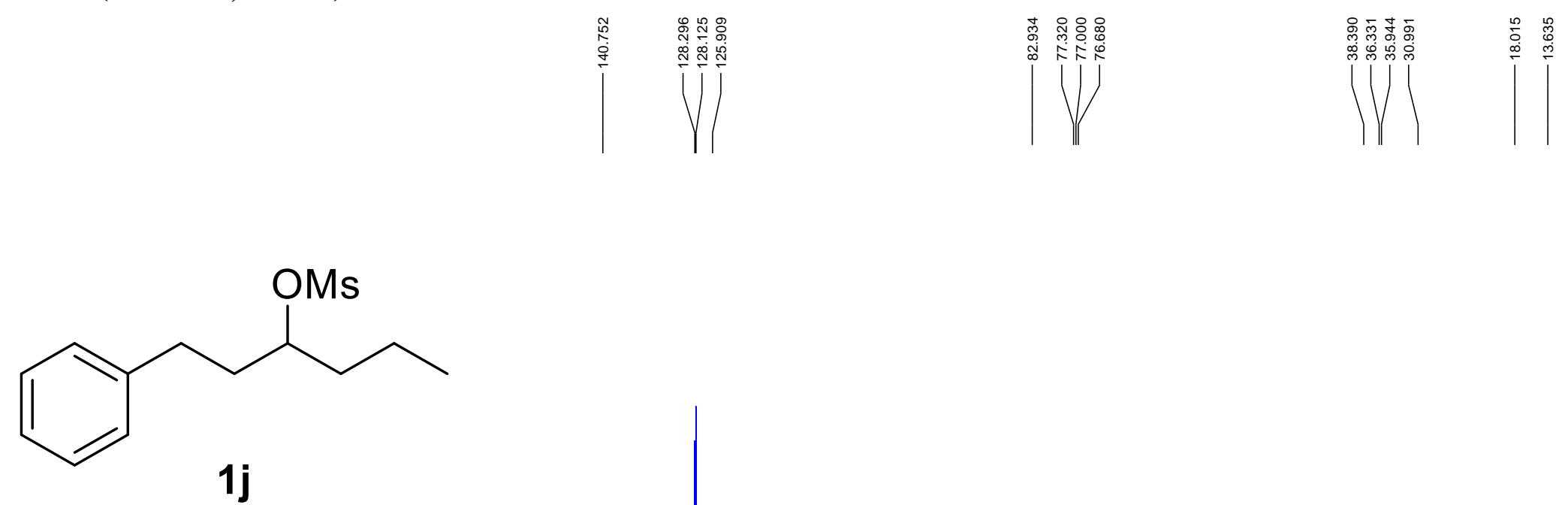

S81 
${ }^{1}$ H NMR (400 MHz, CDCl3)
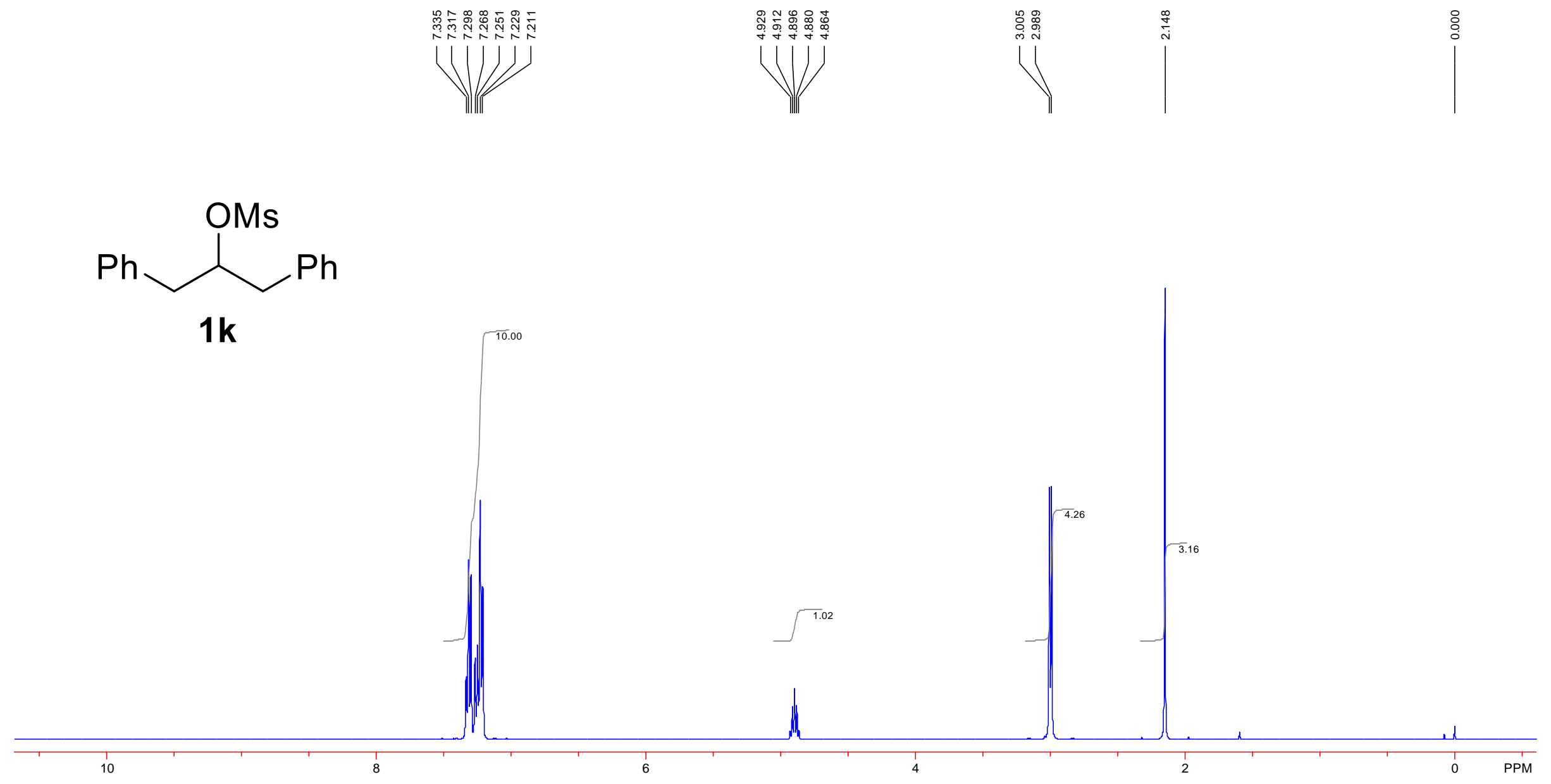
${ }^{13} \mathrm{C}$ NMR (100 MHz, CDCl3)
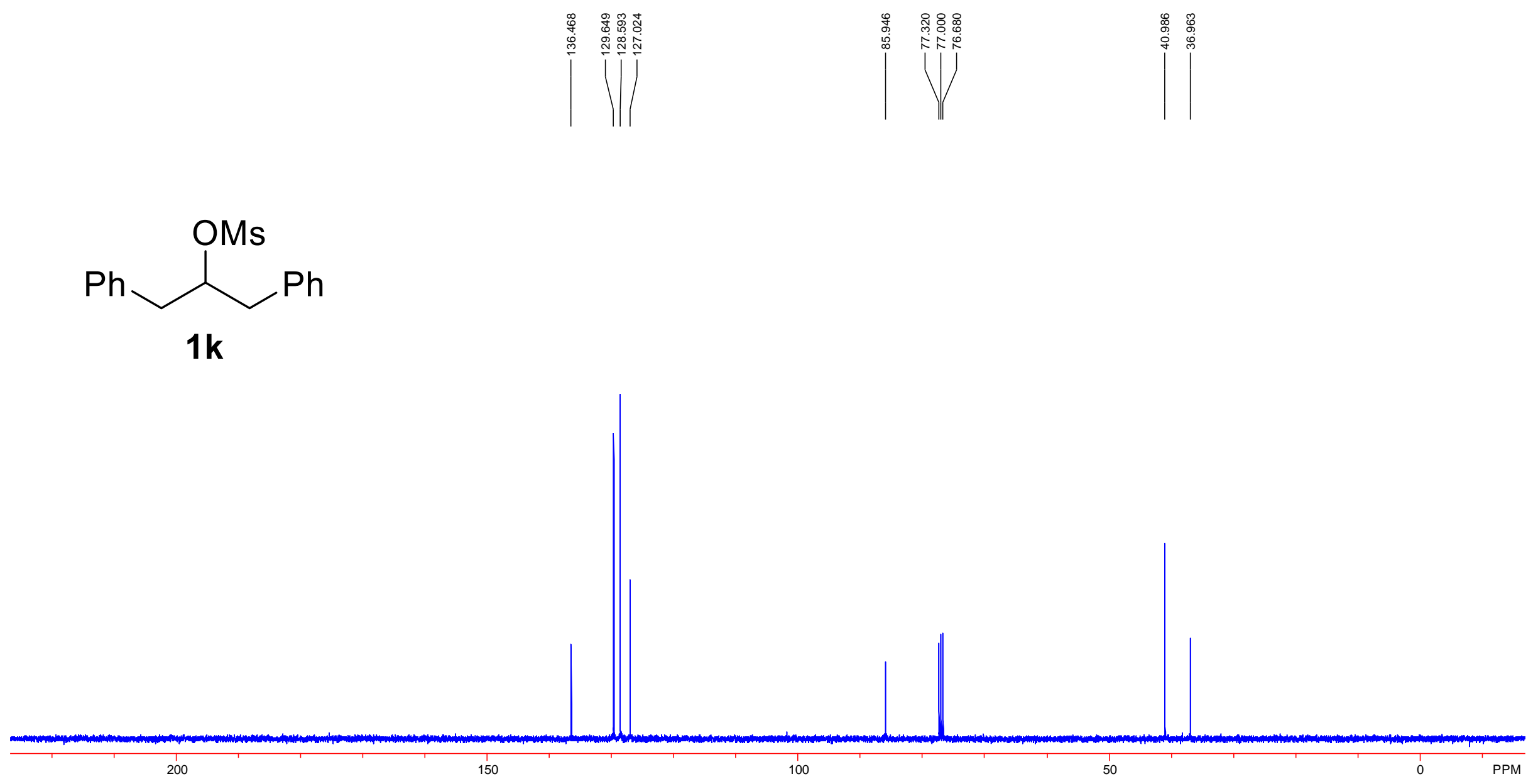
${ }^{1}$ H NMR (400 MHz, CDCl3)
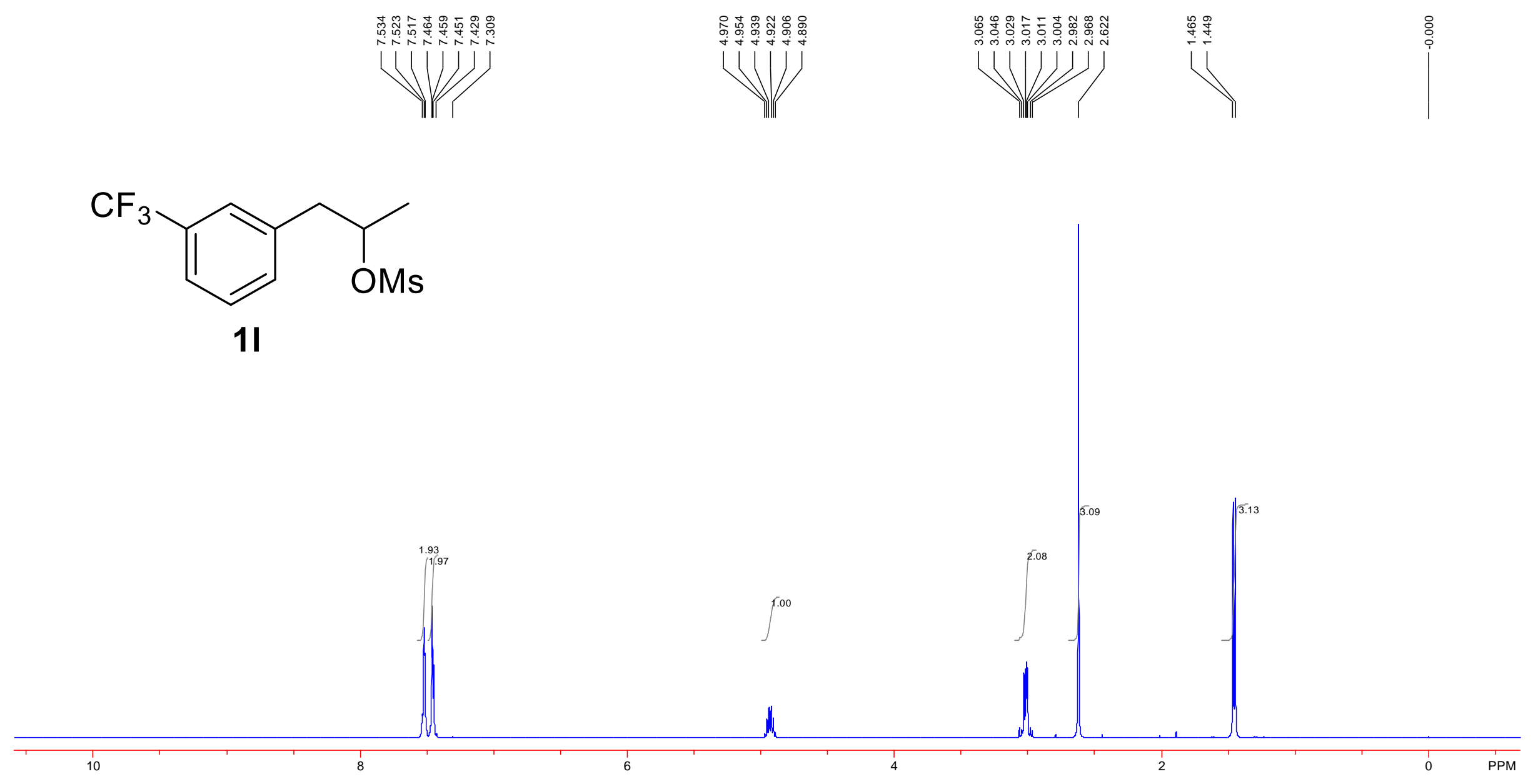
${ }^{13} \mathrm{C}$ NMR (100 MHz, CDCl3)
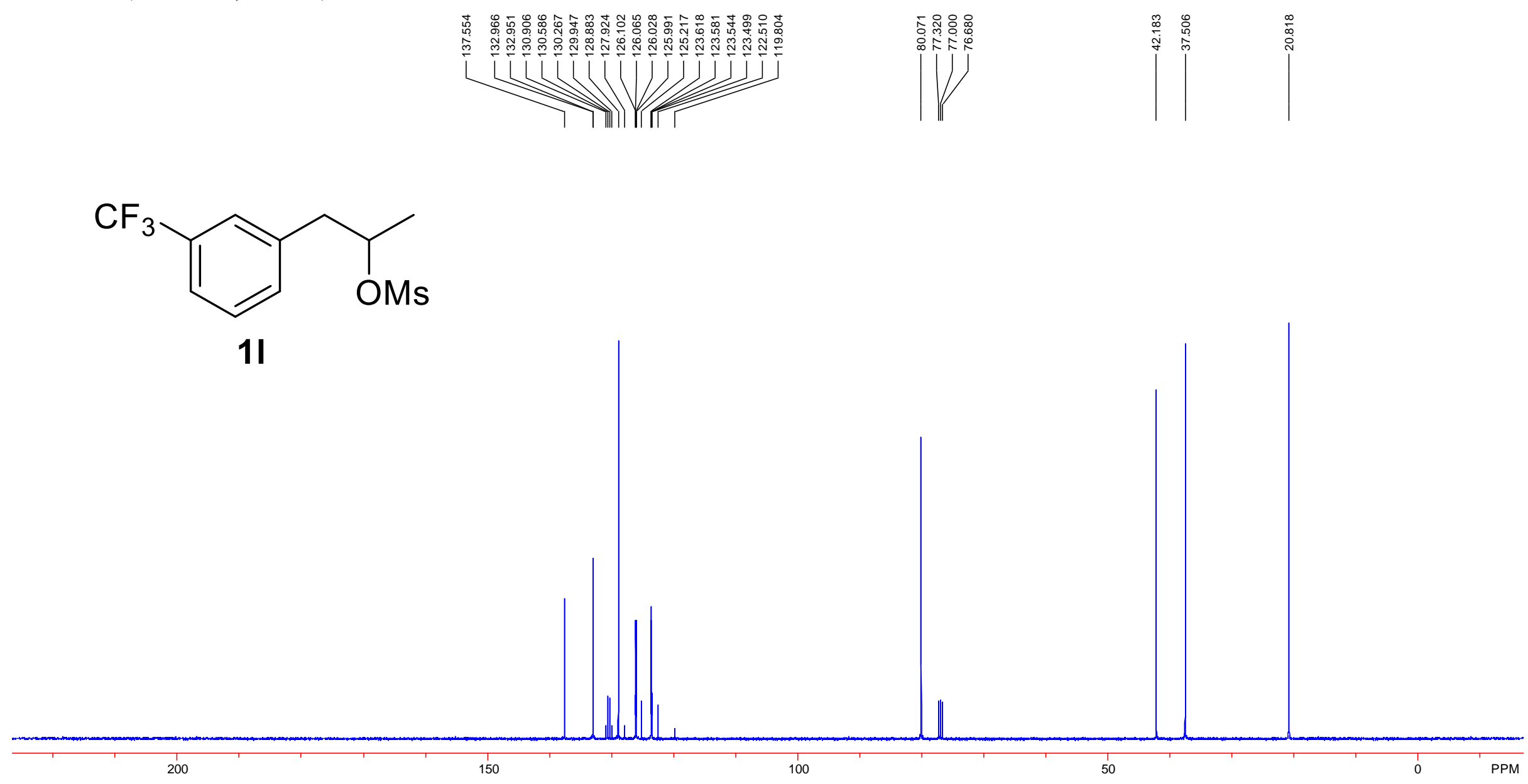
${ }^{1}$ H NMR (400 MHz, CDCl3)
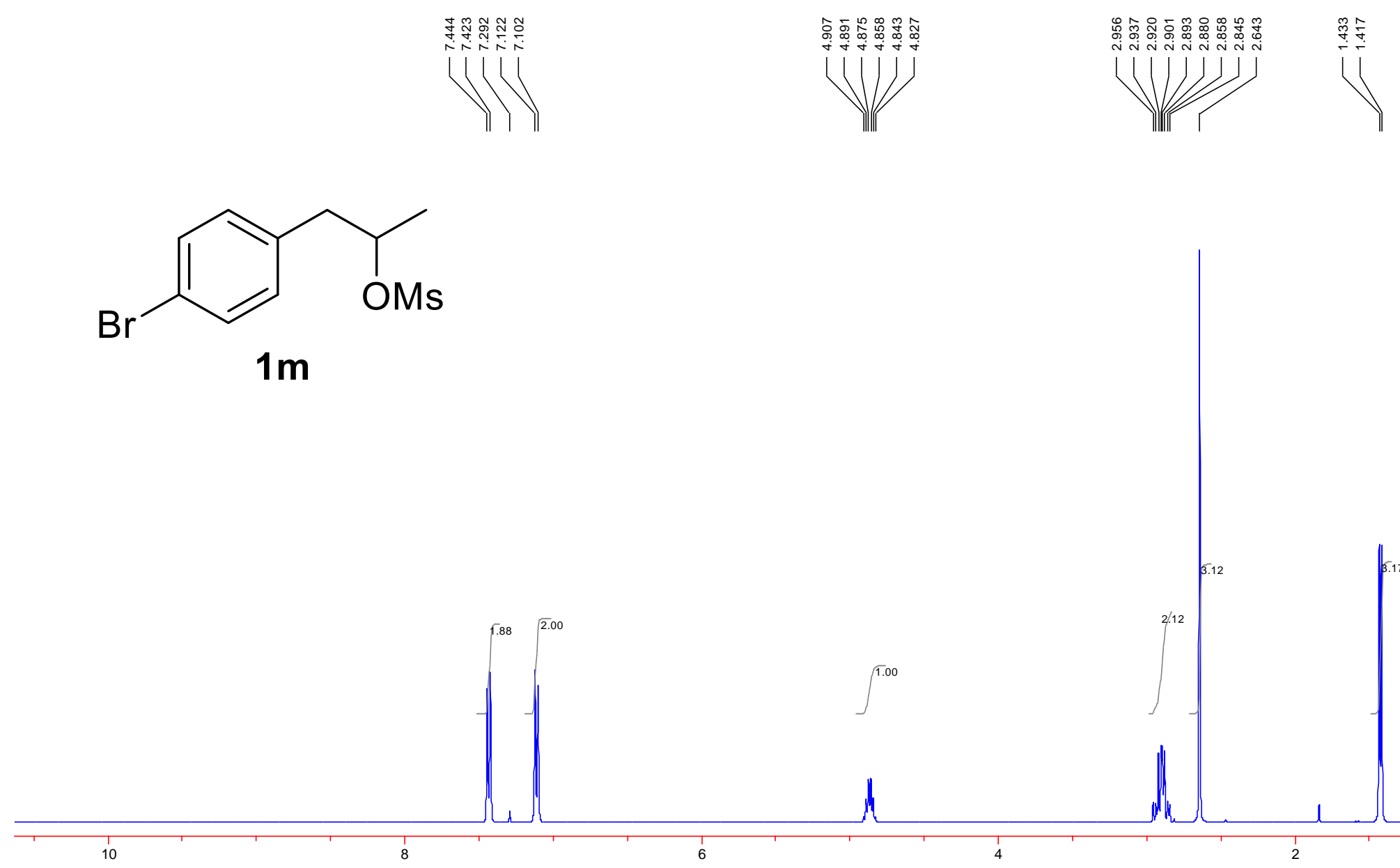

$\int^{1.00}$ 
${ }^{13} \mathrm{C}$ NMR (100 MHz, CDCl3)
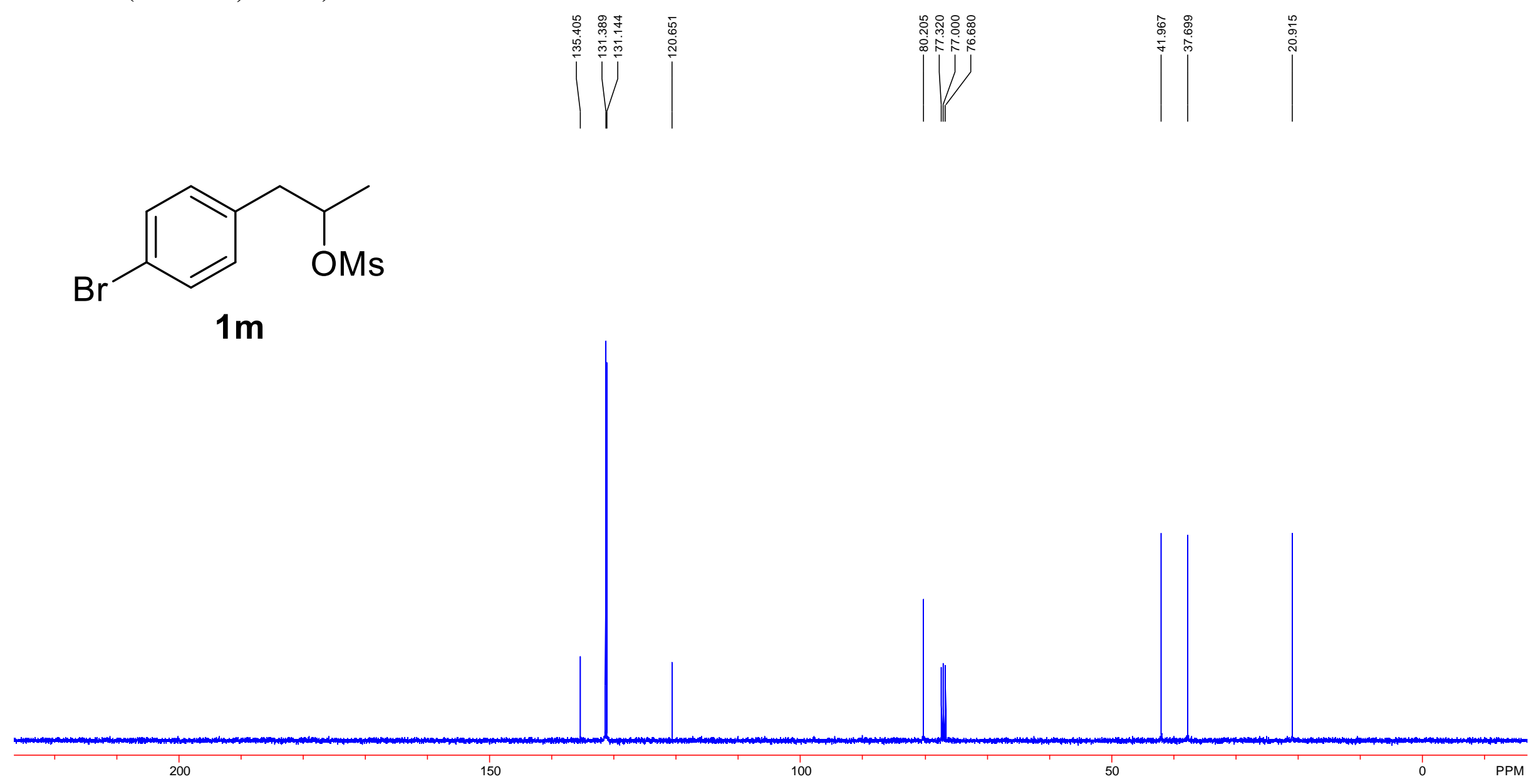
${ }^{1} \mathrm{H}$ NMR (400 MHz, CDCl3)
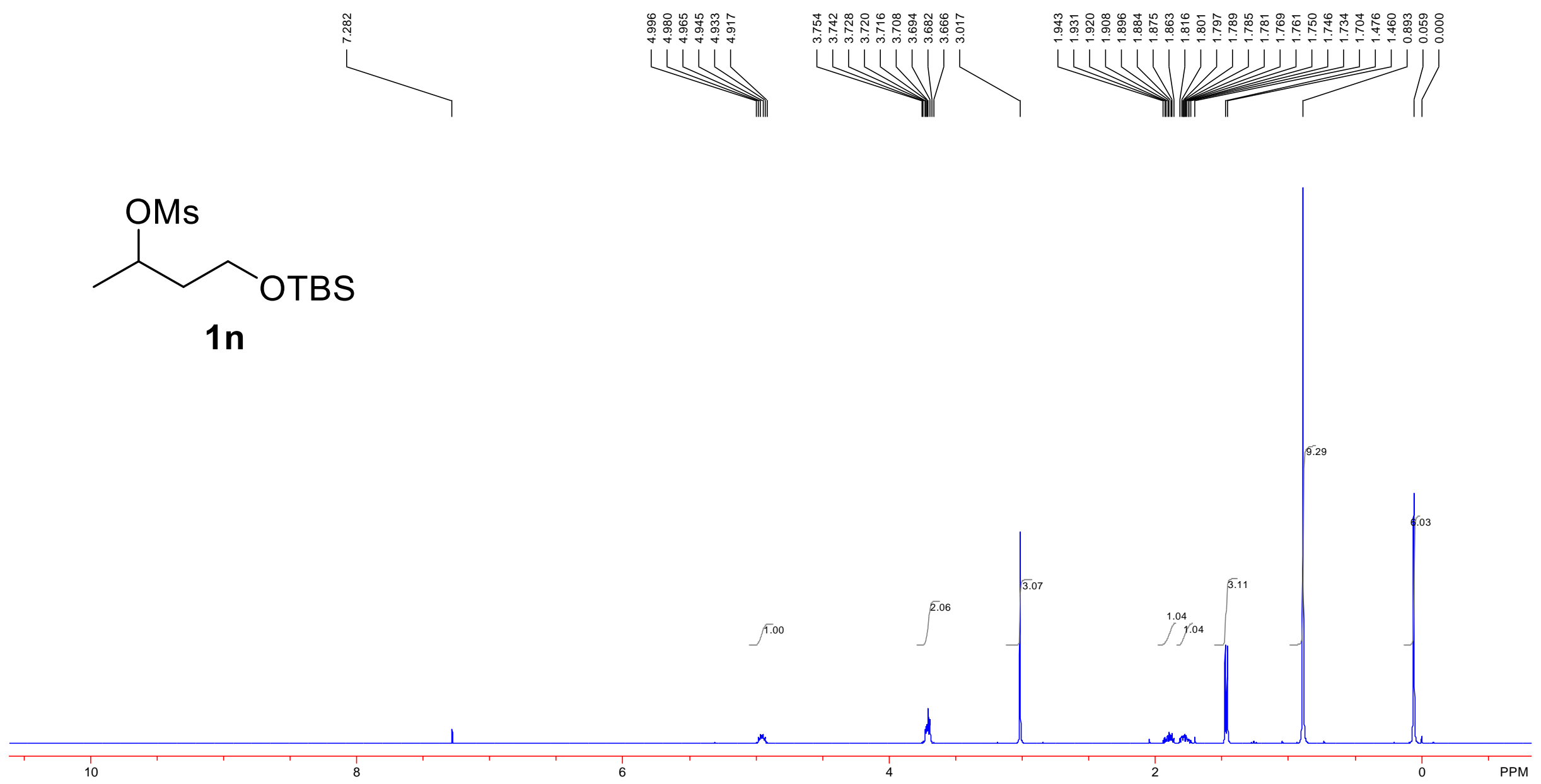
${ }^{13} \mathrm{C}$ NMR (100 MHz, CDCl3)

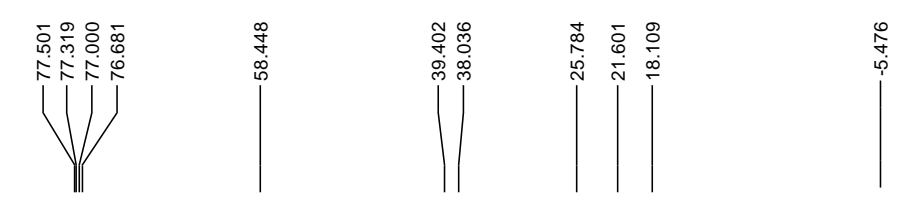<smiles>COC(C)CC[OH+]SC</smiles>

1n 
${ }^{1}$ H NMR (400 MHz, CDCl3)
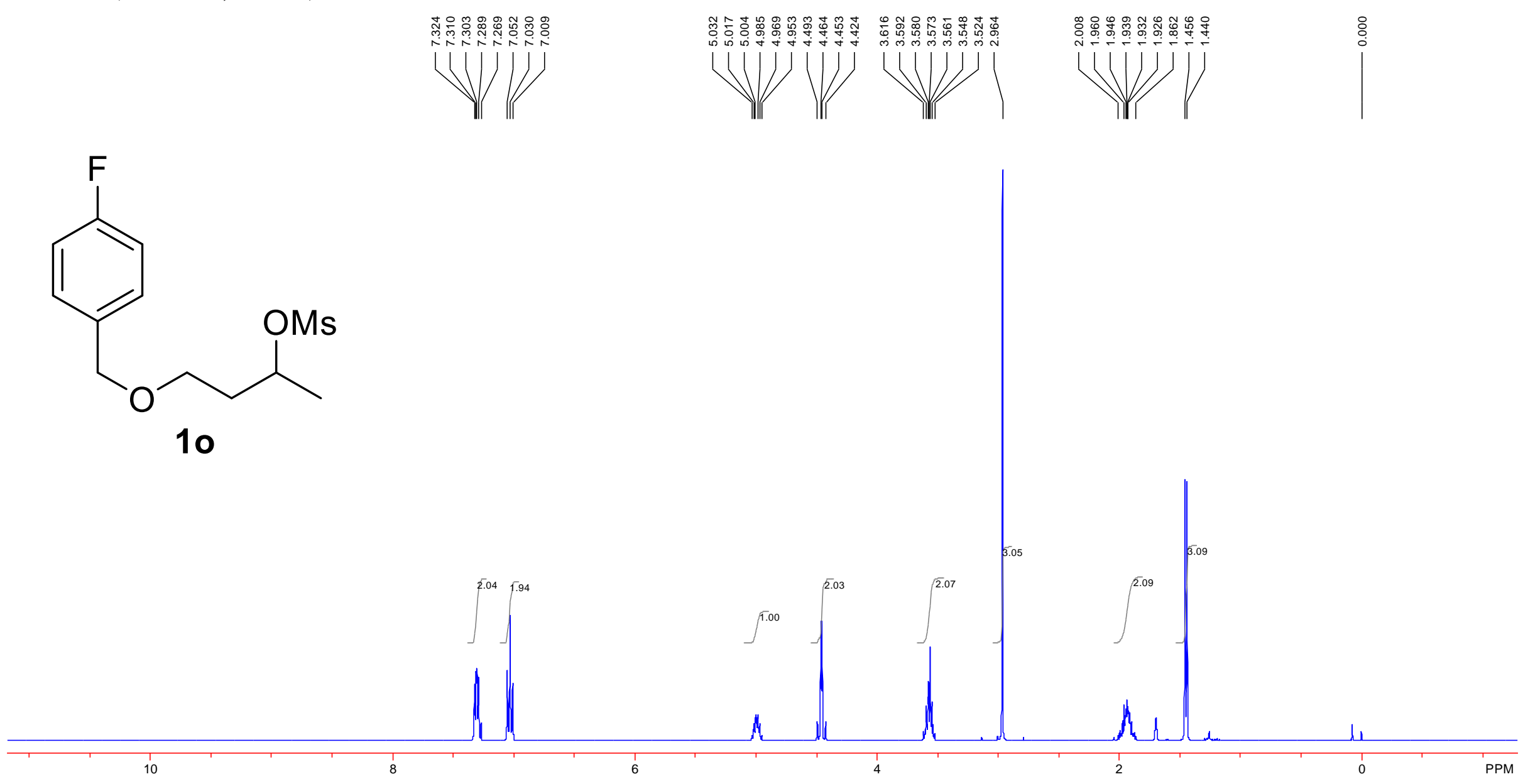
${ }^{13} \mathrm{C}$ NMR (100 MHz, CDCl3)
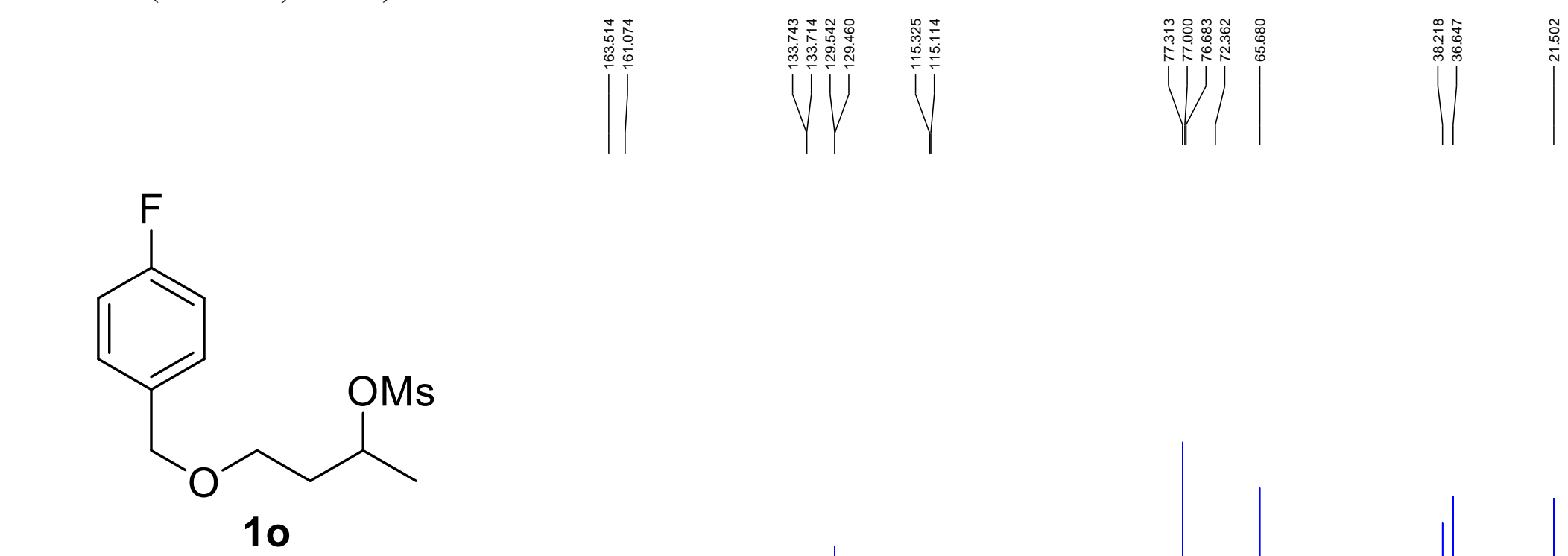

S91 
${ }^{1}$ H NMR (400 MHz, CDCl3)
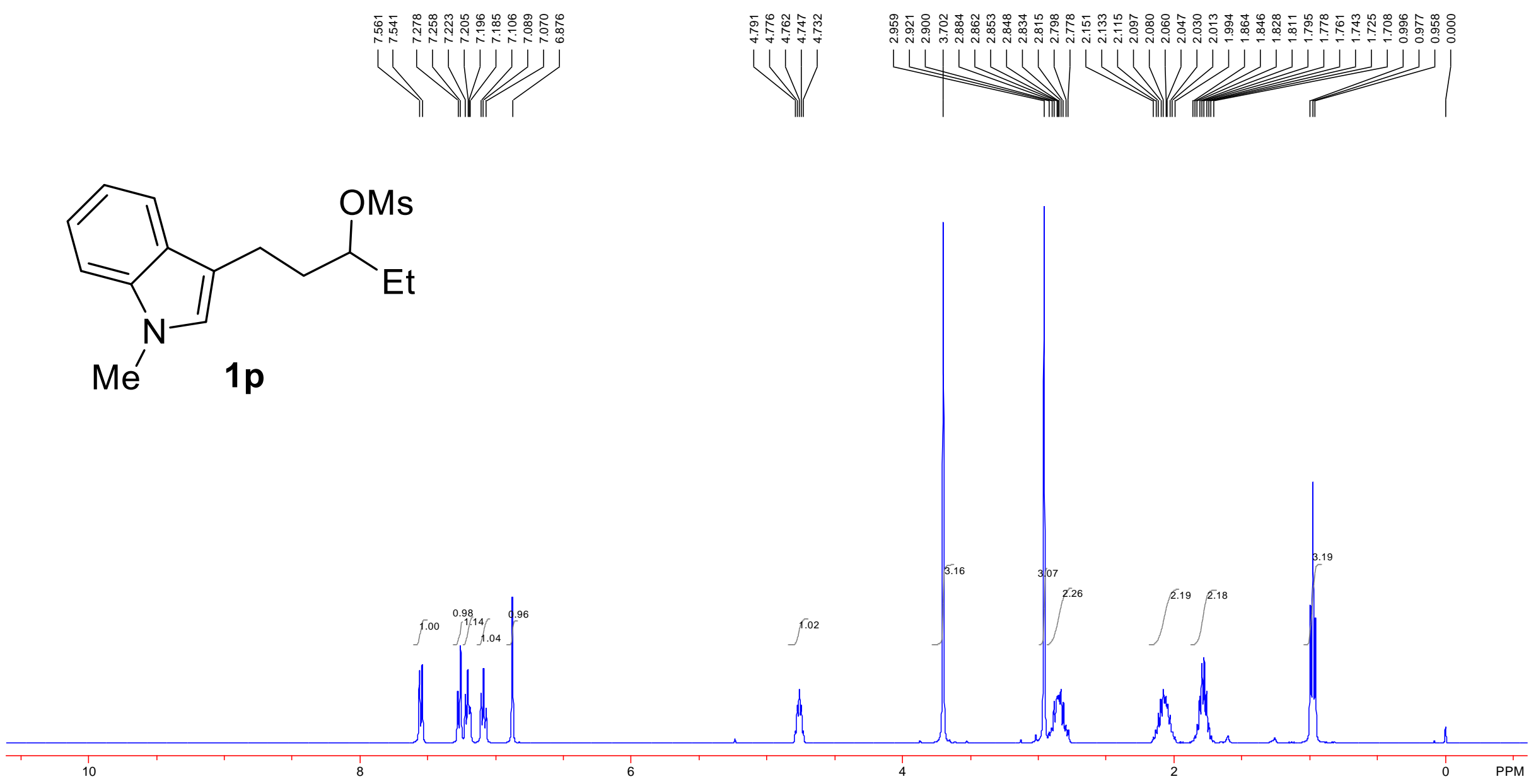
${ }^{13} \mathrm{C}$ NMR (100 MHz, CDCl3)
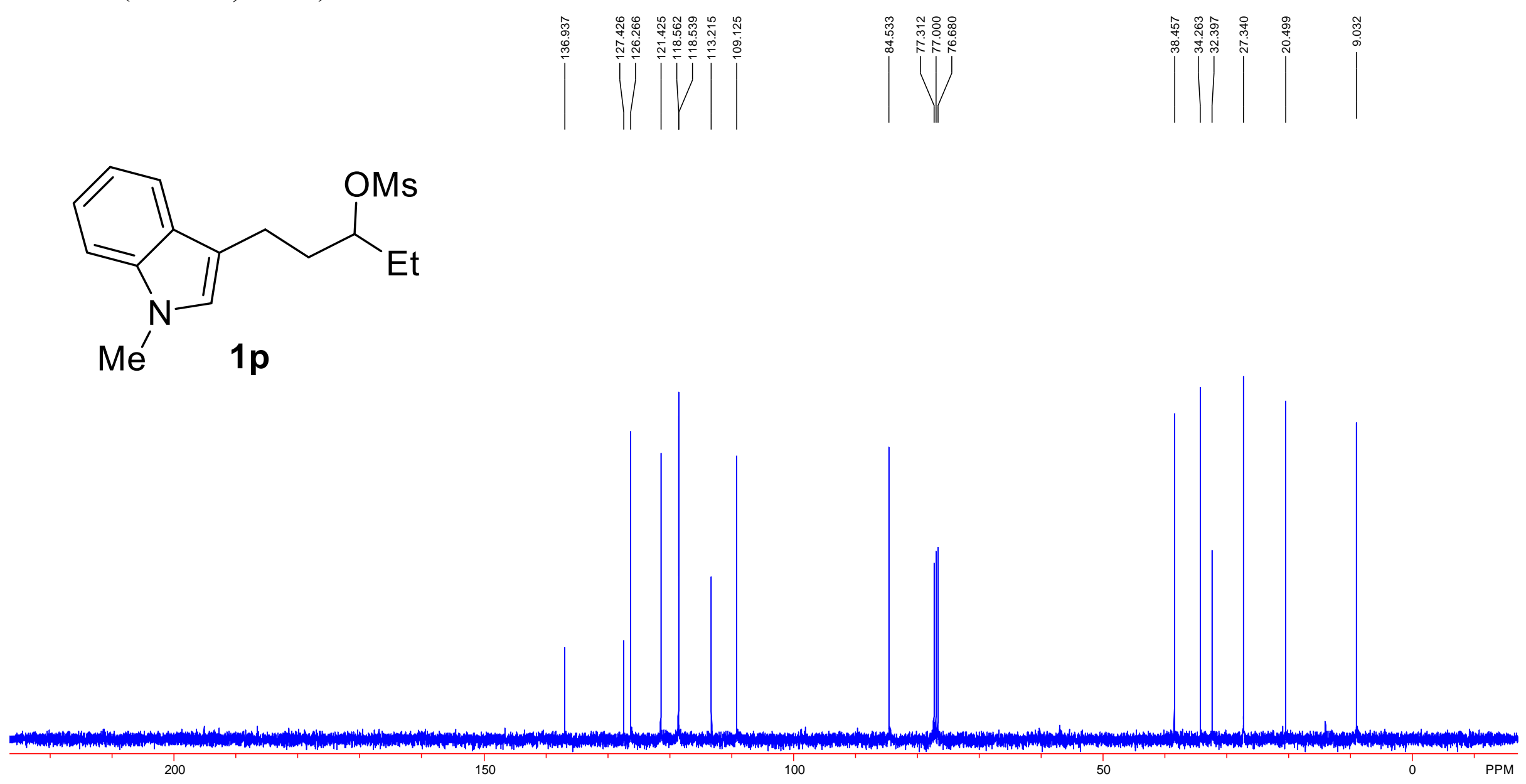
${ }^{1}$ H NMR (400 MHz, CDCl3)
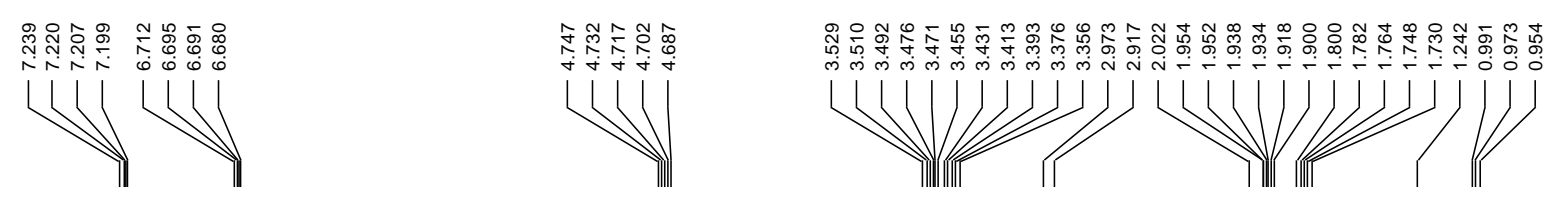<smiles>CCC(CCN(C)c1ccccc1)OC</smiles>

$1 q$

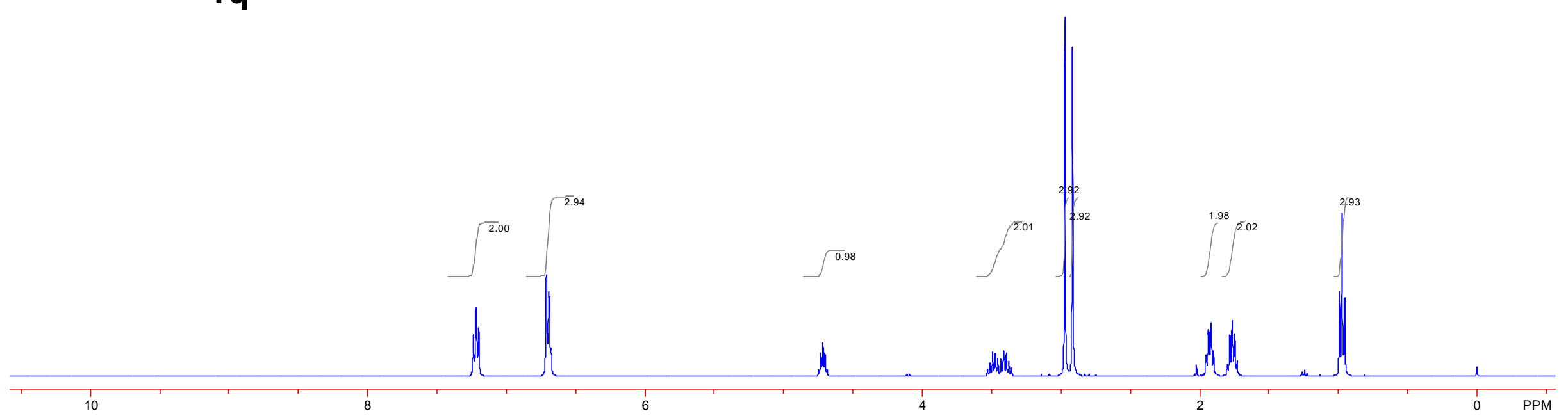


${ }^{13} \mathrm{C}$ NMR (100 MHz, CDCl3)

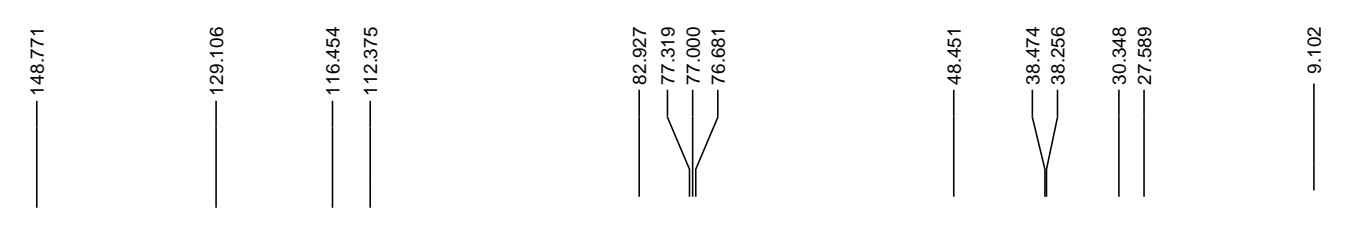<smiles>CCC(CCN(C)c1ccccc1)OC</smiles>

$1 q$

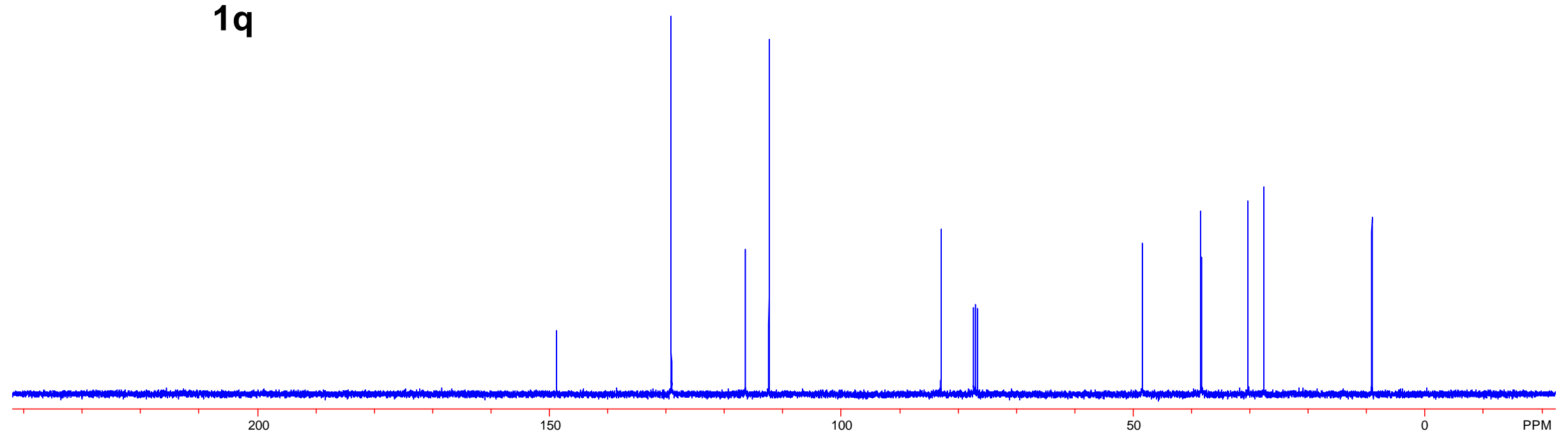


${ }^{1}$ H NMR (400 MHz, CDCl3)

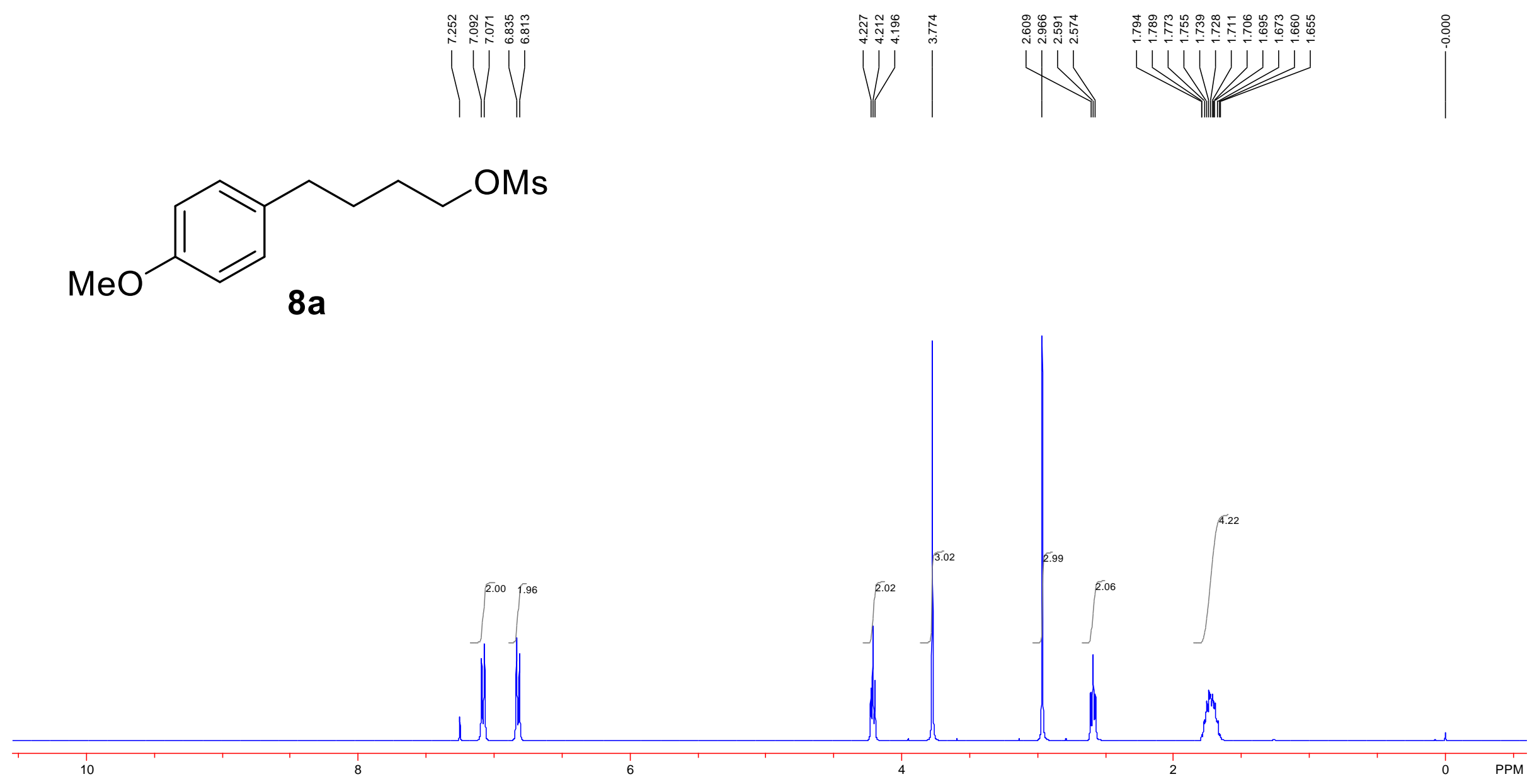


${ }^{13} \mathrm{C}$ NMR (100 MHz, CDCl3)
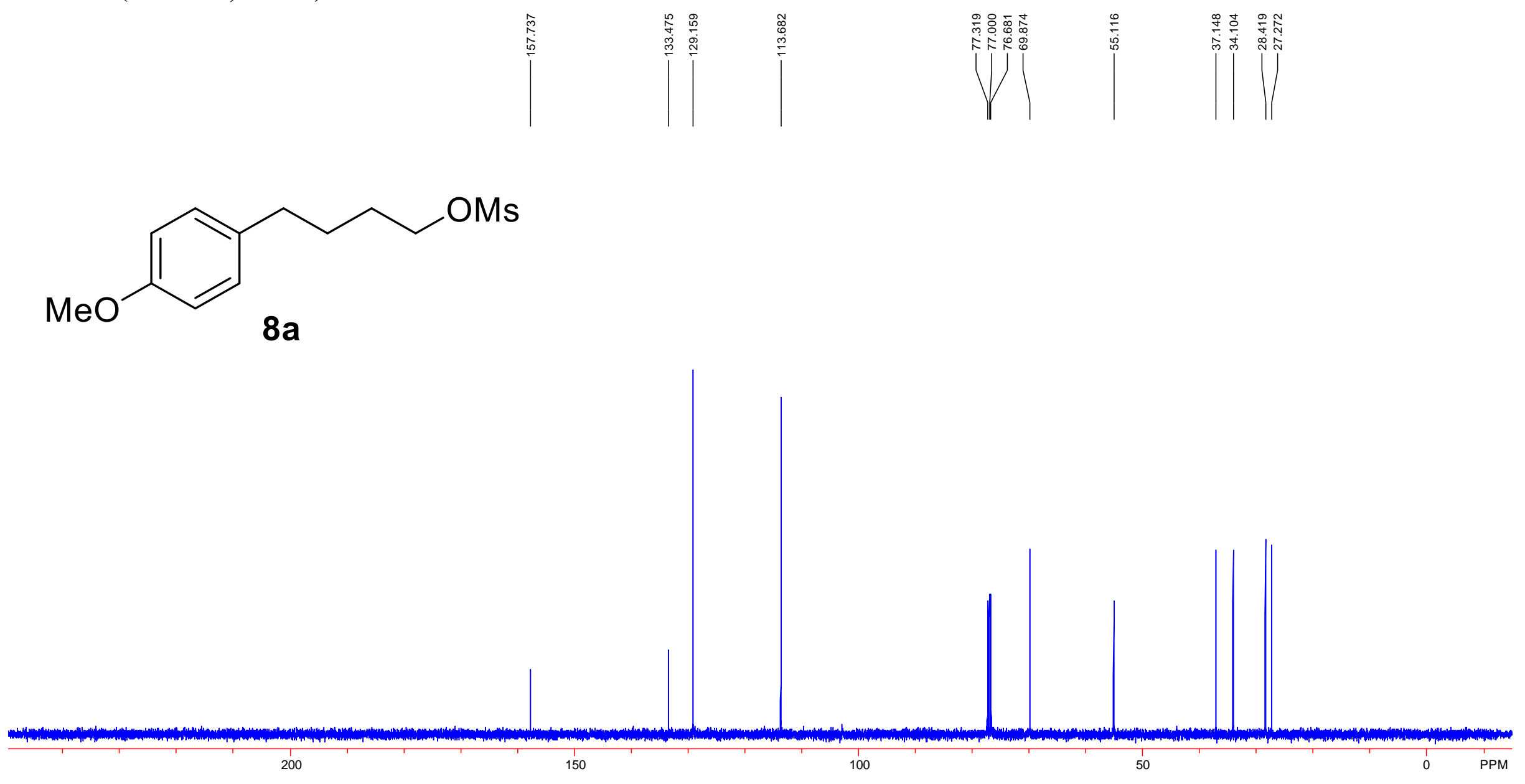
${ }^{1}$ H NMR (400 MHz, CDCl3)
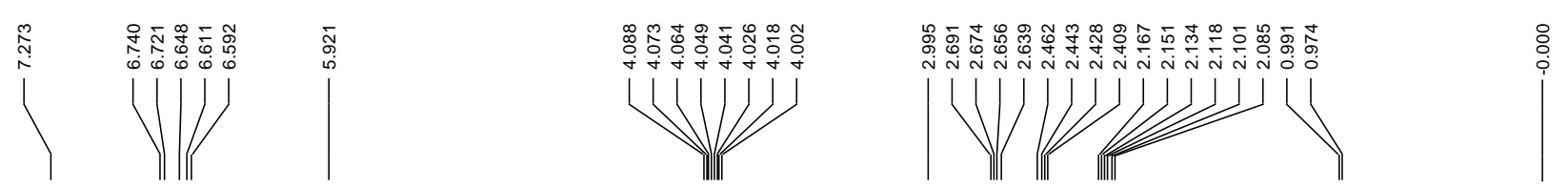<smiles>COCC(C)Cc1ccc2c(c1)OCO2</smiles>

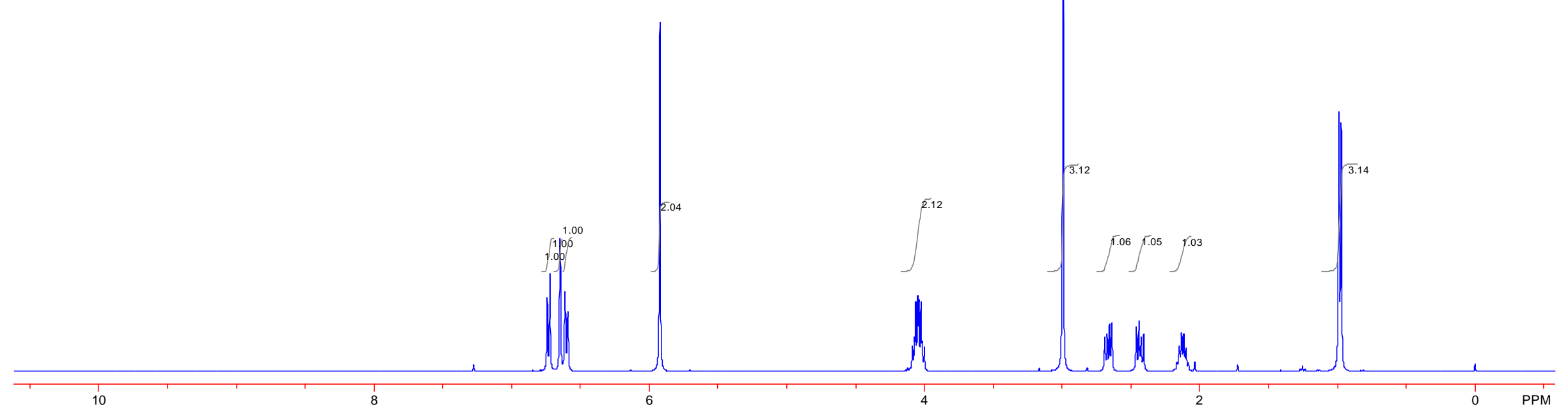


${ }^{13} \mathrm{C}$ NMR (100 MHz, CDCl3)
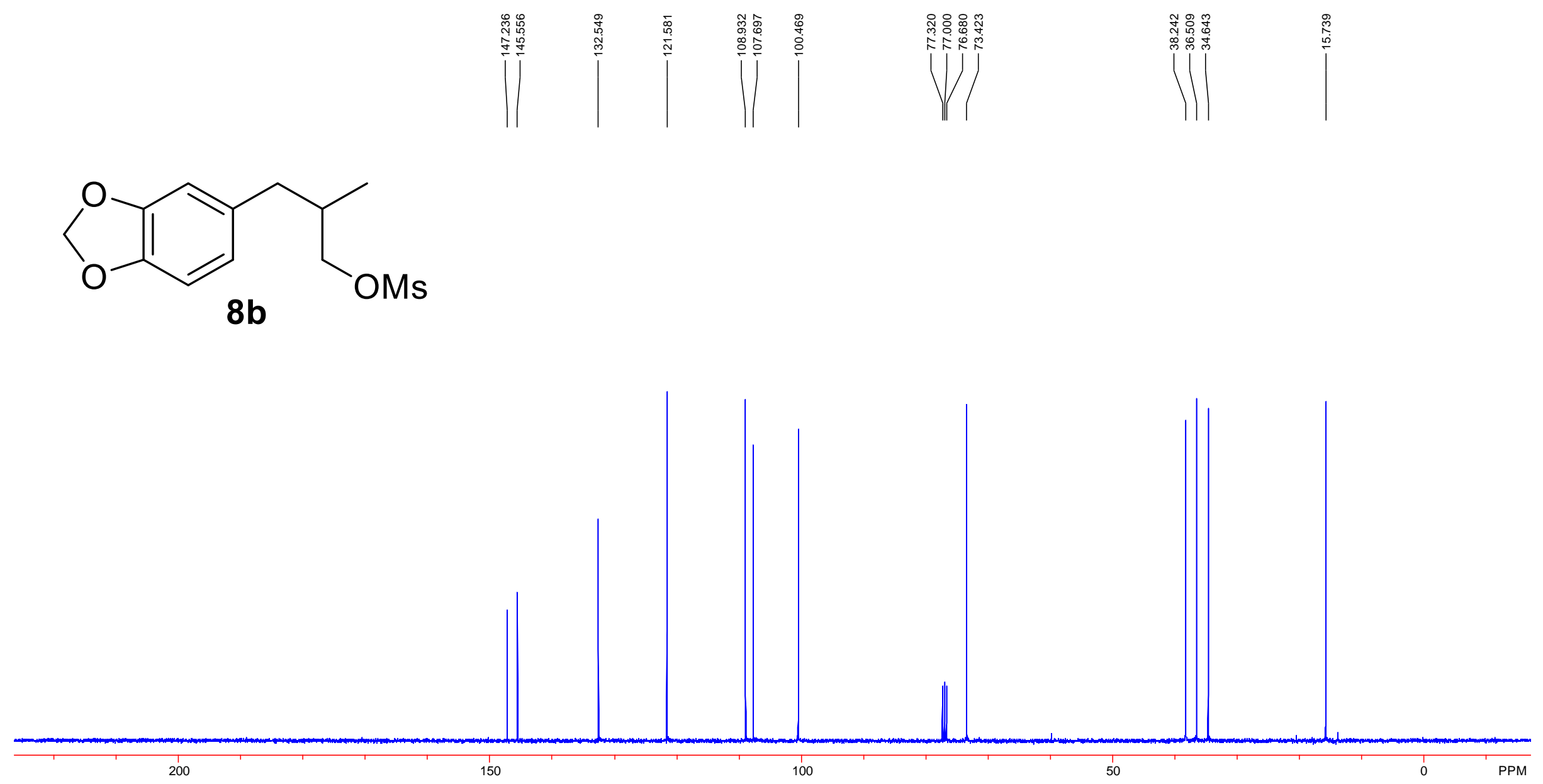


\section{${ }^{1} \mathrm{H}$ NMR (400 MHz, CDCl3)}

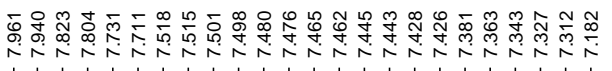

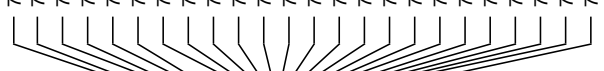

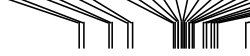

$8 c$

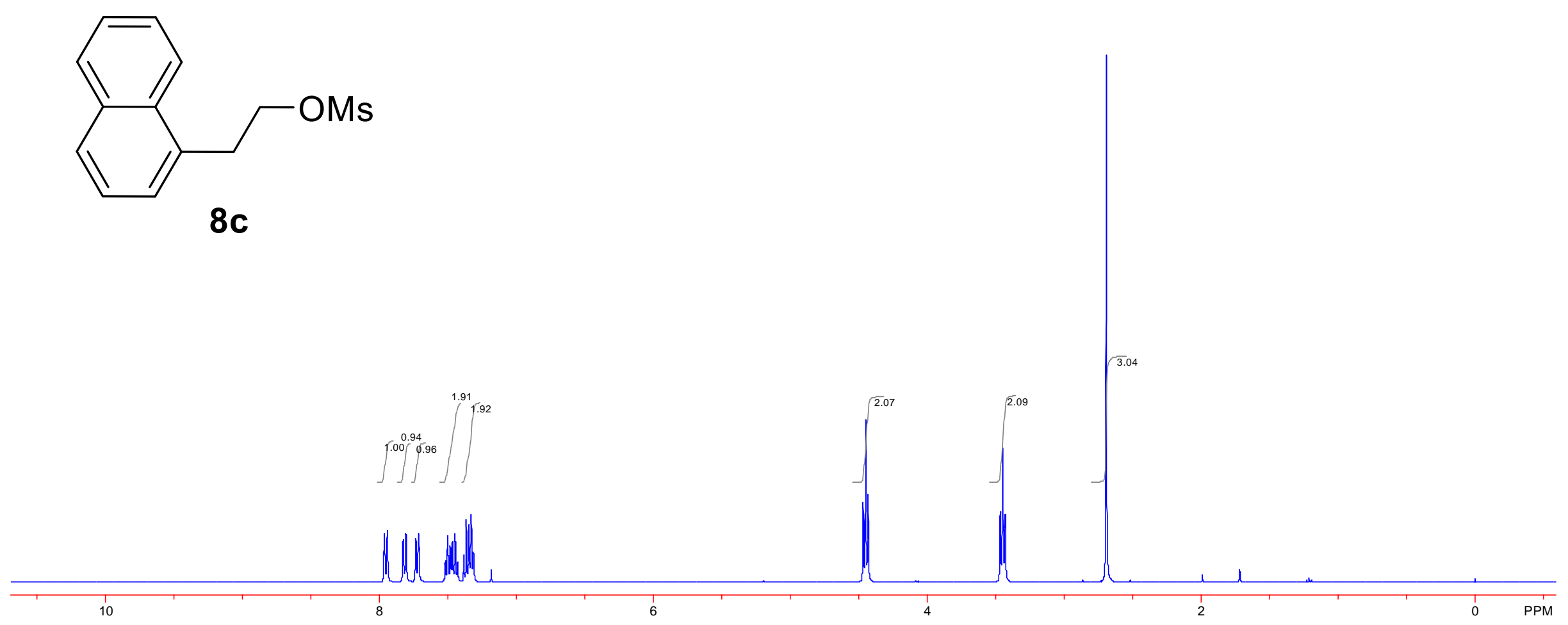

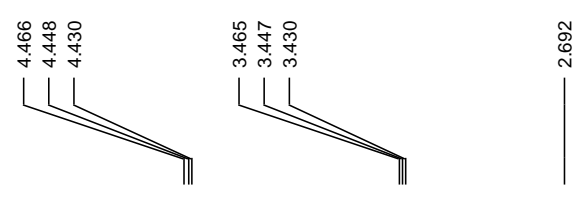

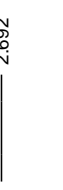

i 
${ }^{13} \mathrm{C}$ NMR (100 MHz, CDCl3)
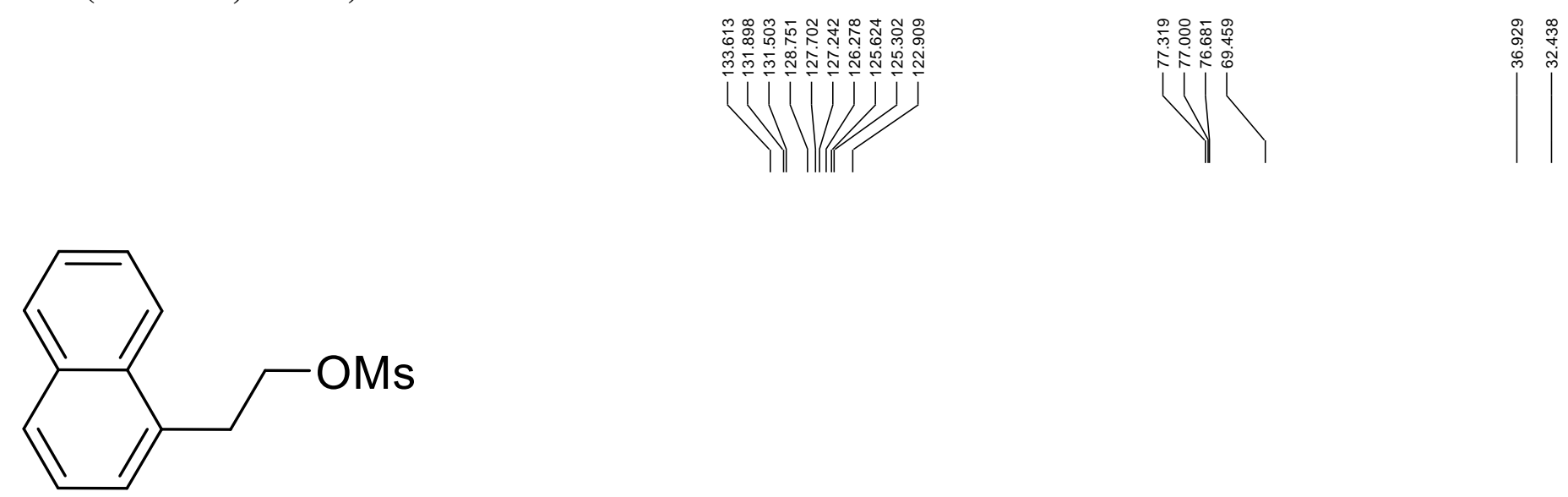

$8 c$

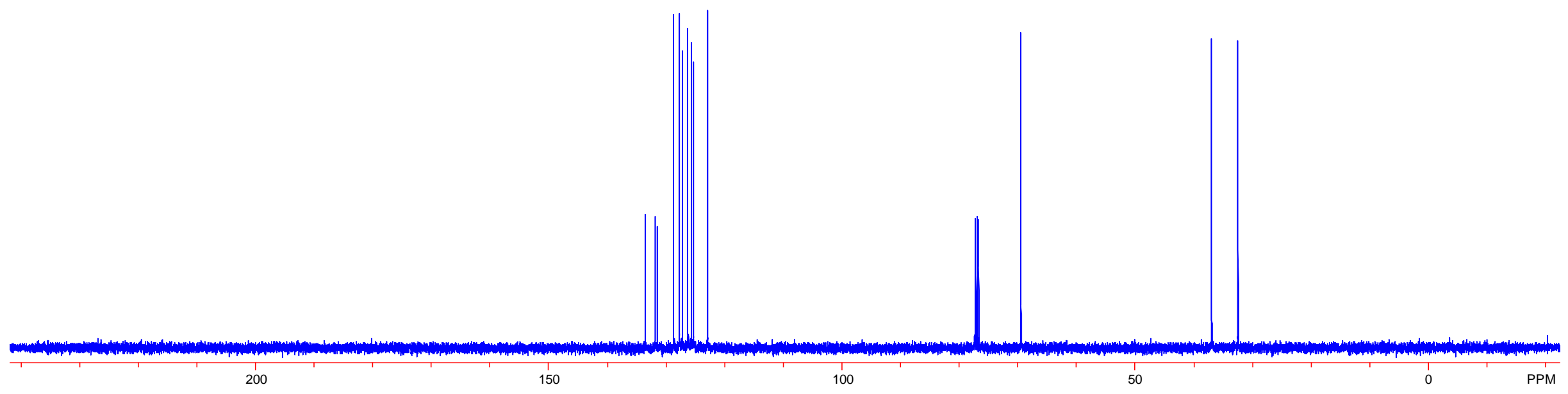


${ }^{1}$ H NMR (400 MHz, CDCl3)

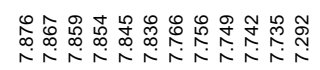

WWHity<smiles>COCCCN1C(=O)c2ccccc2C1=O</smiles>

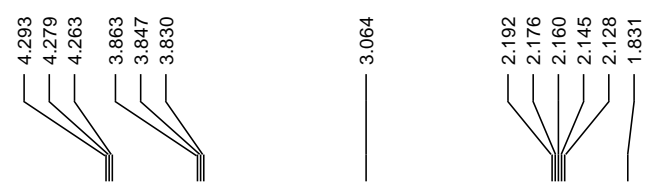

$\stackrel{\circ}{\circ}$

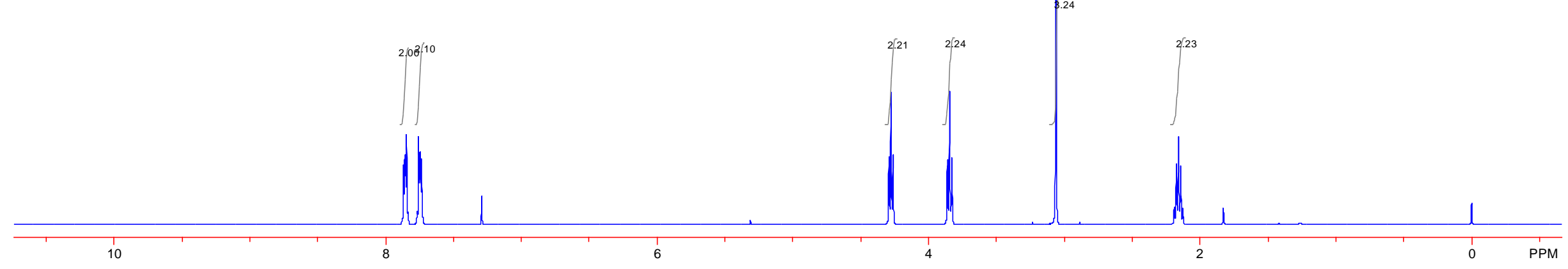


${ }^{13} \mathrm{C}$ NMR (100 MHz, CDCl3)
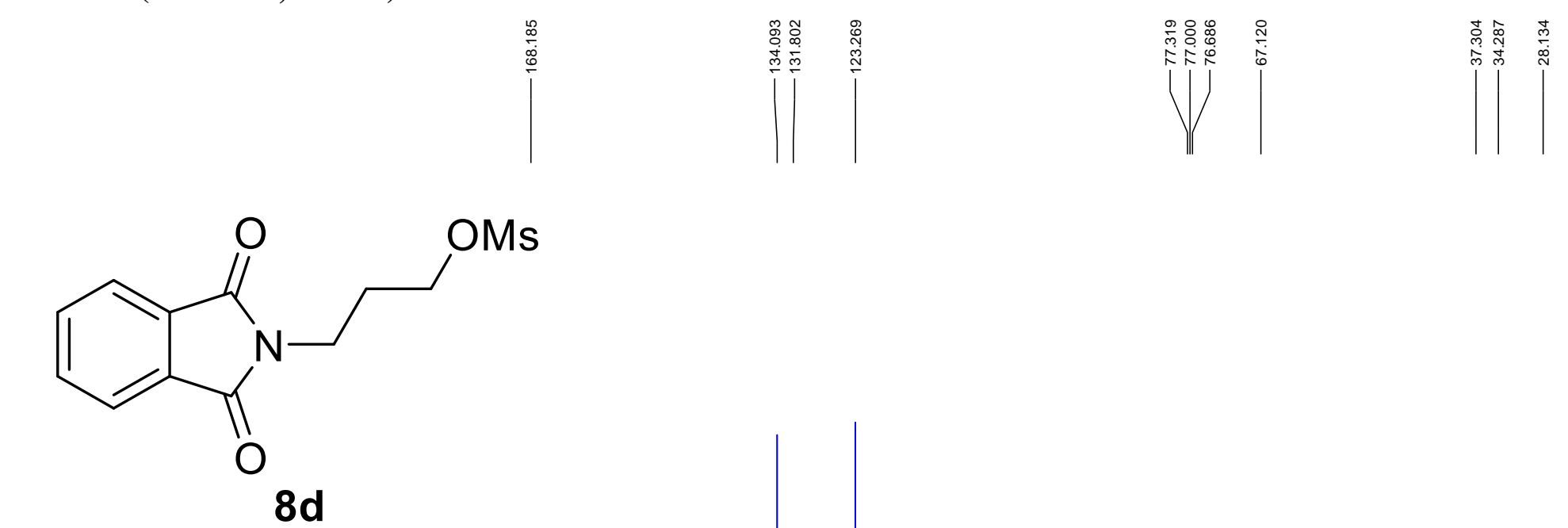
${ }^{1}$ H NMR (400 MHz, CDCl3)
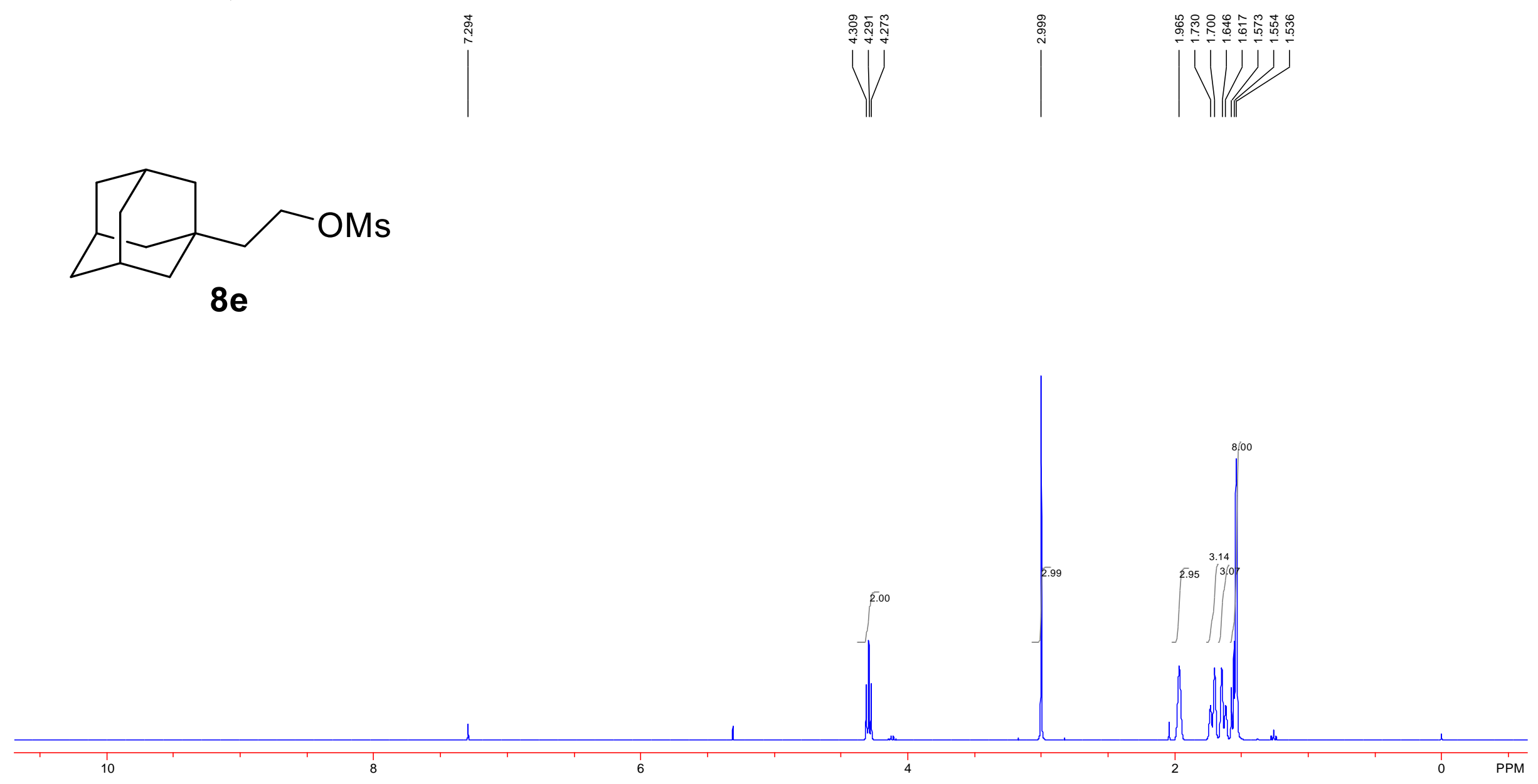
${ }^{13} \mathrm{C}$ NMR (100 MHz, CDCl3)
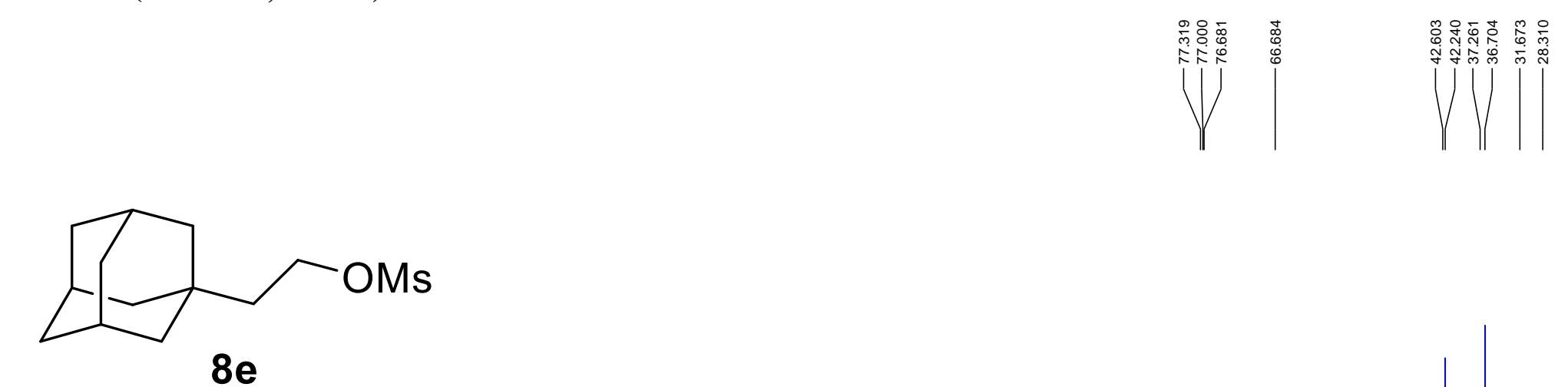
${ }^{1} \mathrm{H}$ NMR (400 MHz, CDCl3)
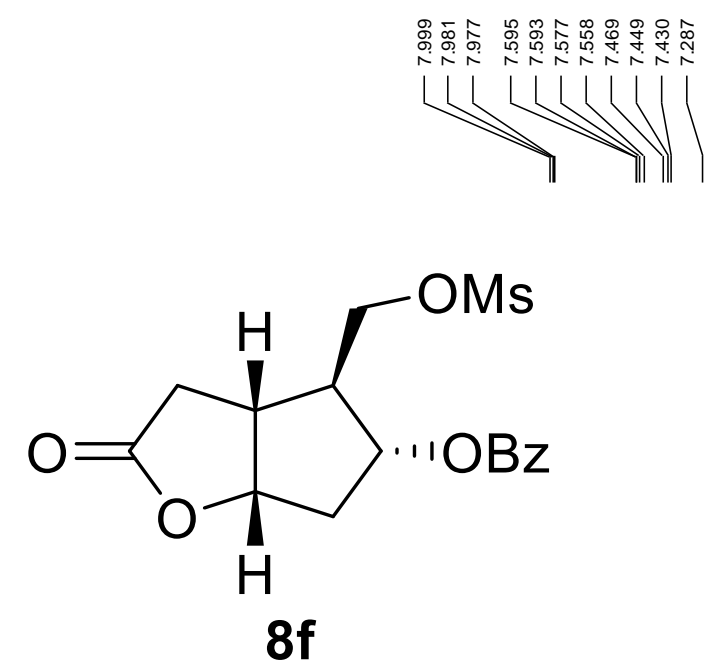

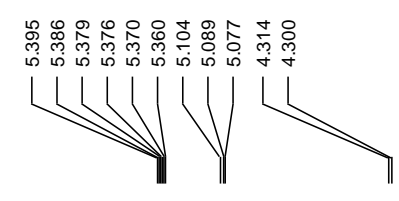

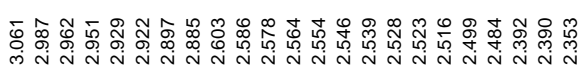

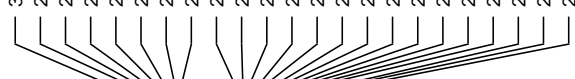

YII Nin

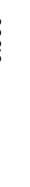


${ }^{13} \mathrm{C}$ NMR (100 MHz, CDCl3)
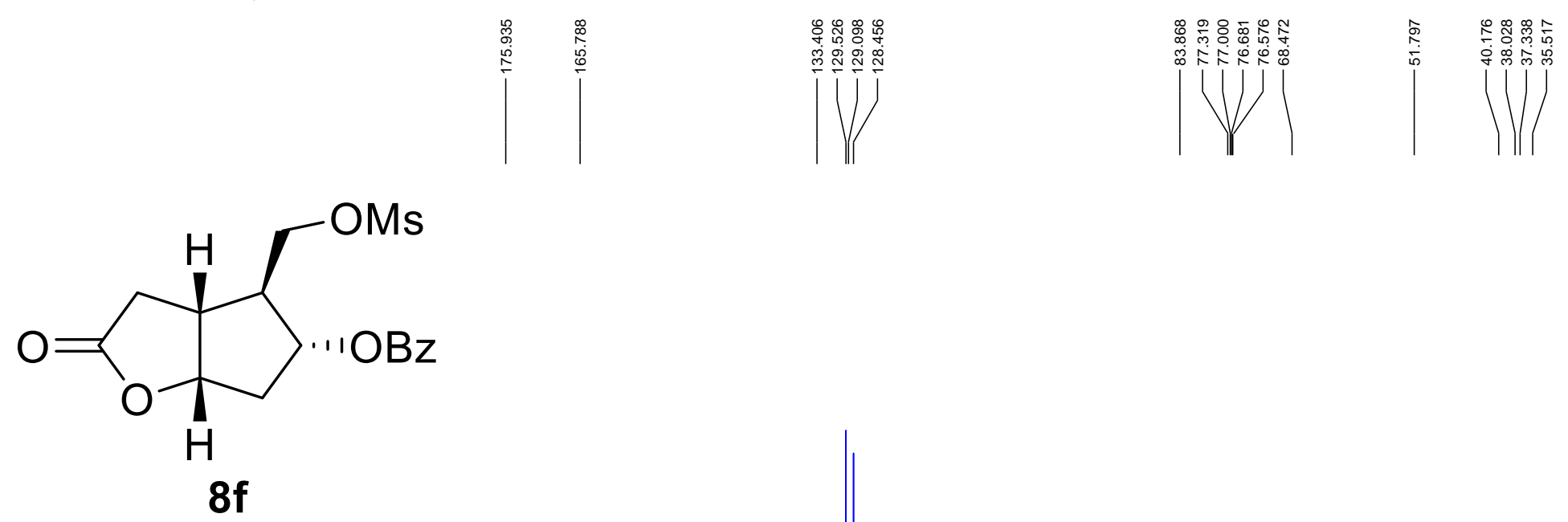
${ }^{1}$ H NMR (400 MHz, CDCl3)
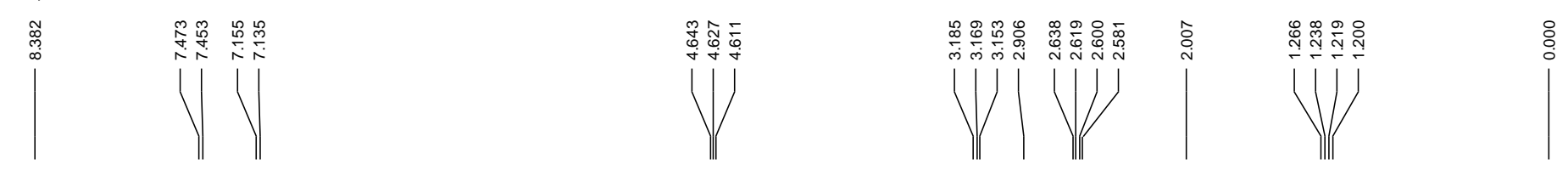<smiles>CCc1ccc(CCOC)nc1</smiles>

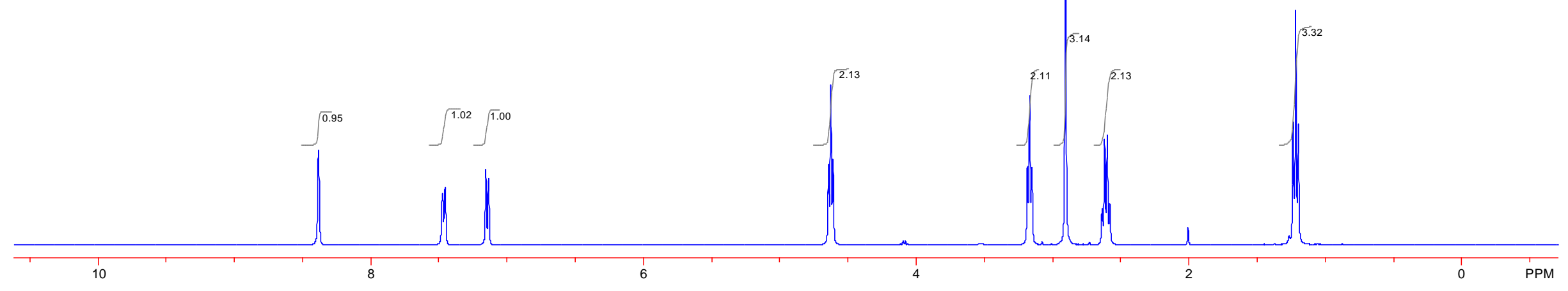


${ }^{13} \mathrm{C}$ NMR (100 MHz, CDCl3)

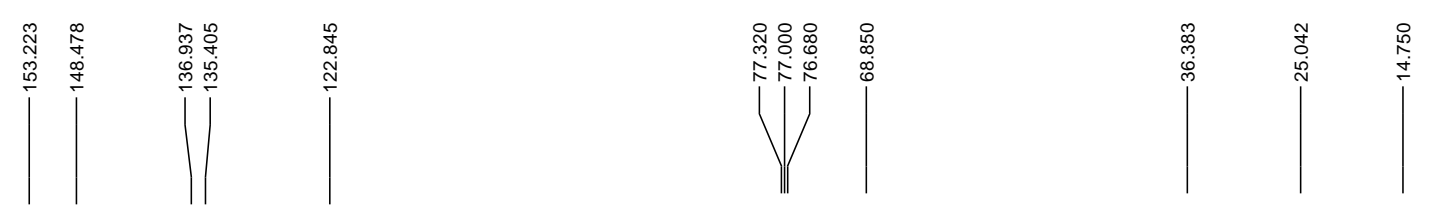<smiles>CCc1ccc(CCOC)nc1</smiles>

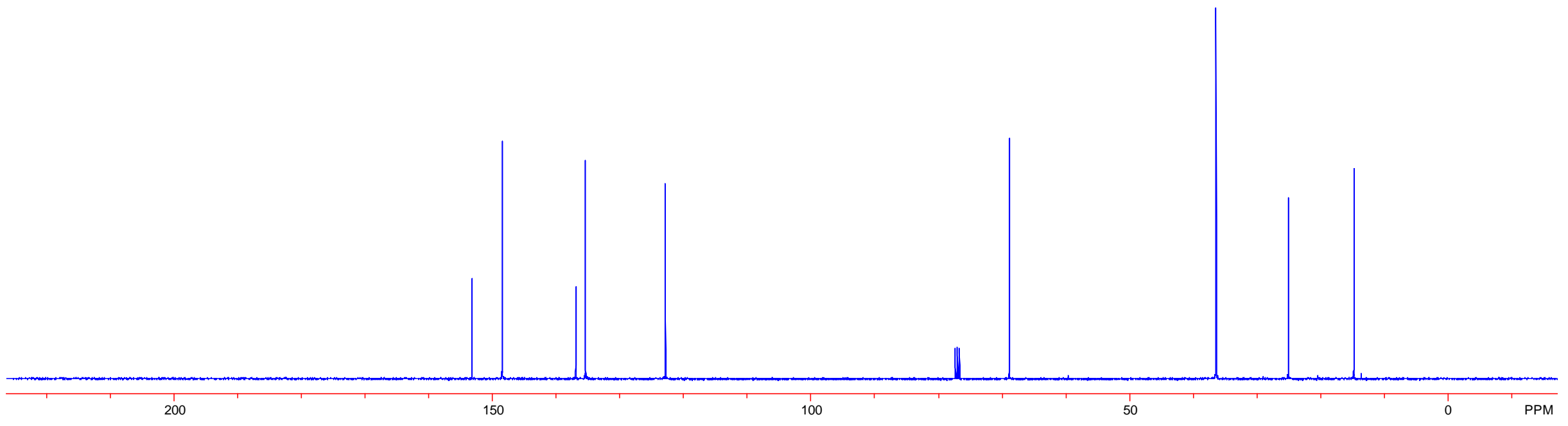


${ }^{1}$ H NMR (400 MHz, CDCl3)
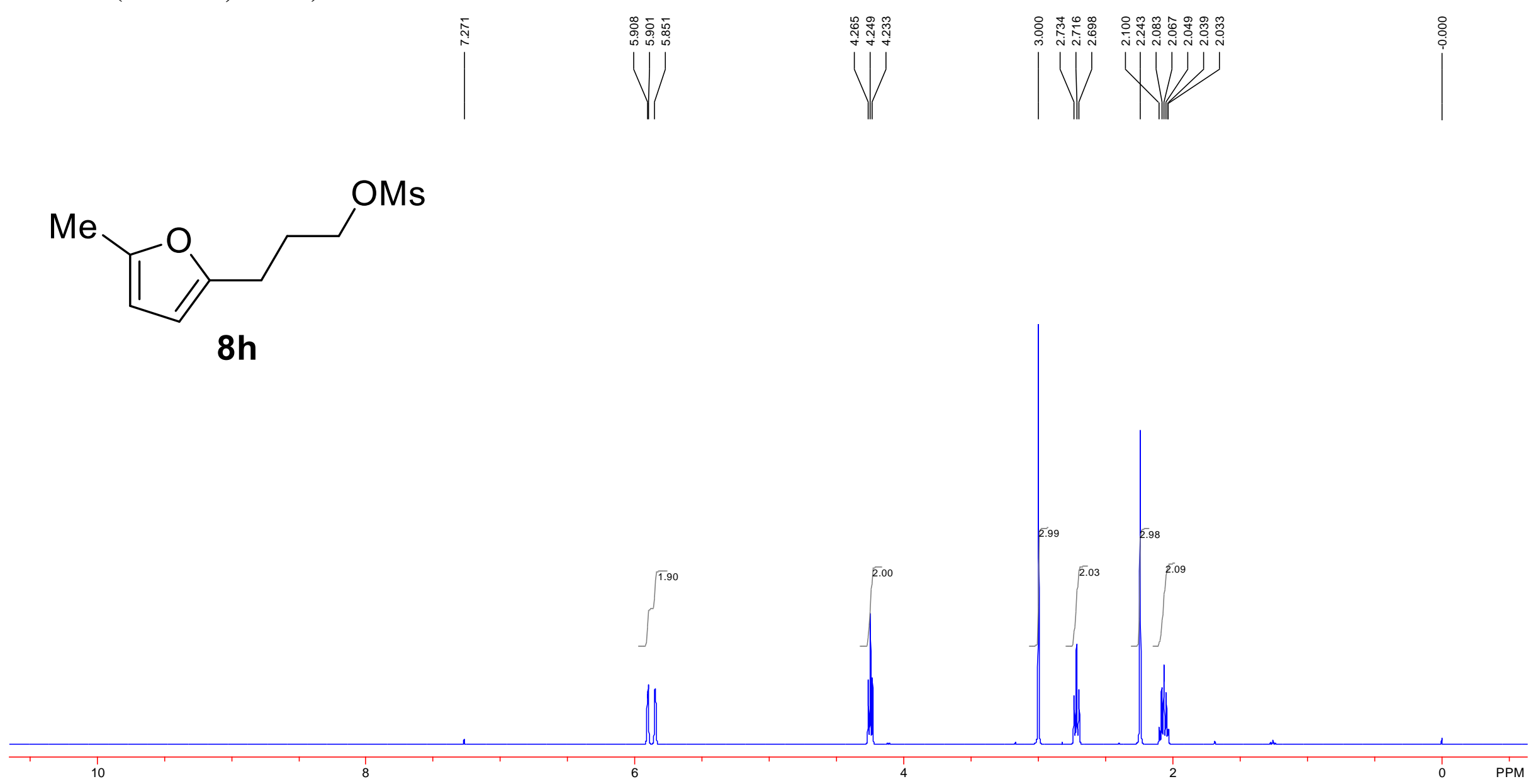
${ }^{13} \mathrm{C}$ NMR (100 MHz, CDCl3)
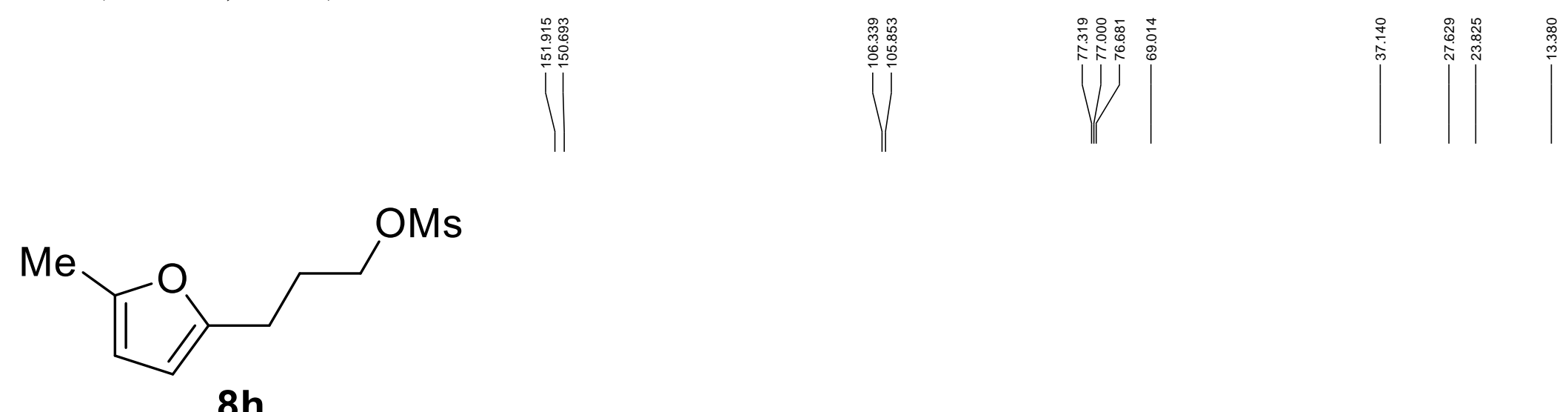

$8 h$

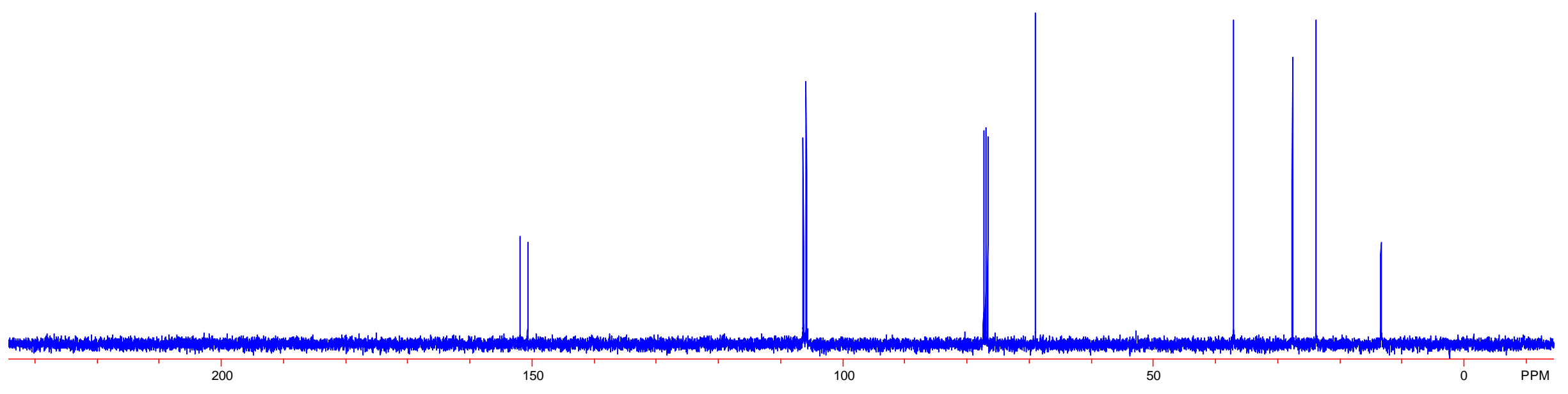


${ }^{1}$ H NMR (400 MHz, CDCl3)
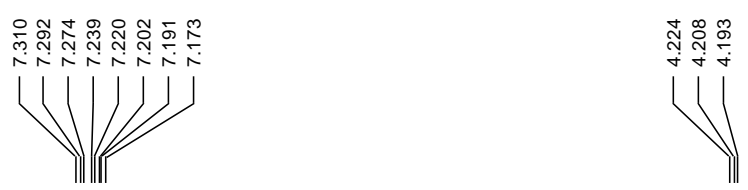

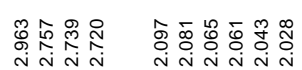

IV WH
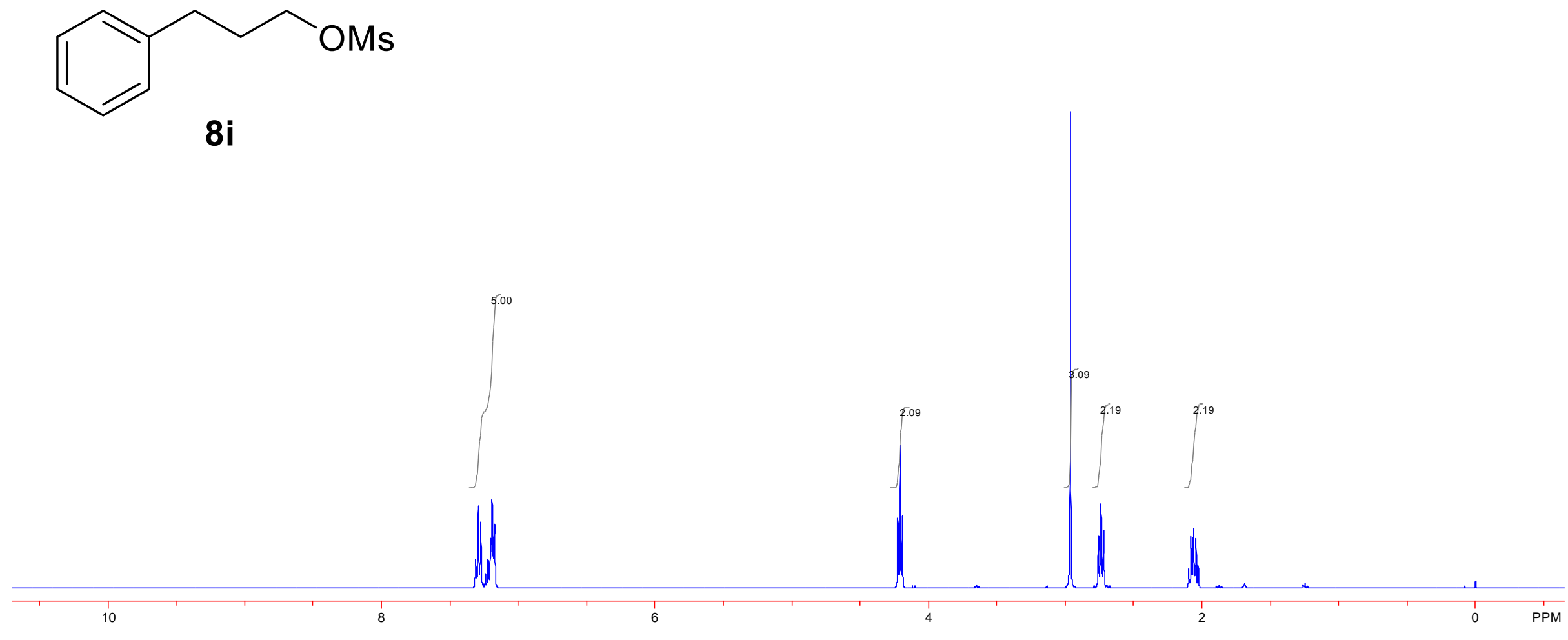
${ }^{13} \mathrm{C}$ NMR (100 MHz, CDCl3)

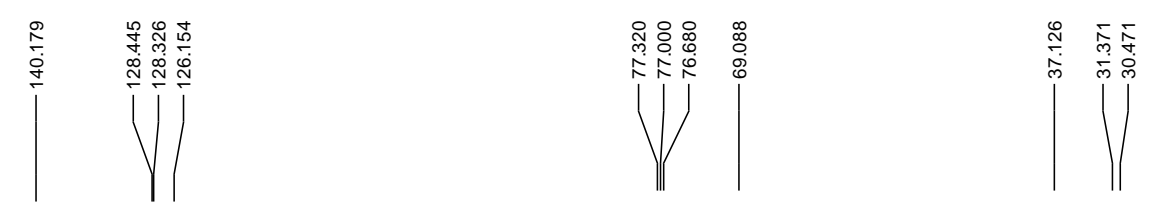

$\overbrace{8 \mathrm{i}} \mathrm{OMs}$

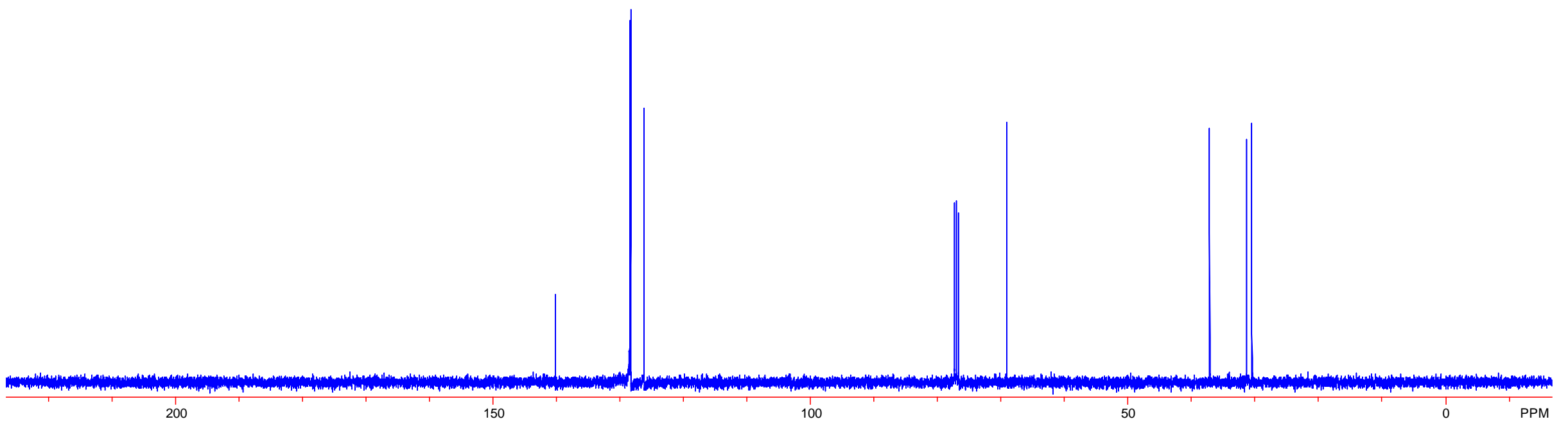


${ }^{1}$ H NMR (400 MHz, CDCl3)
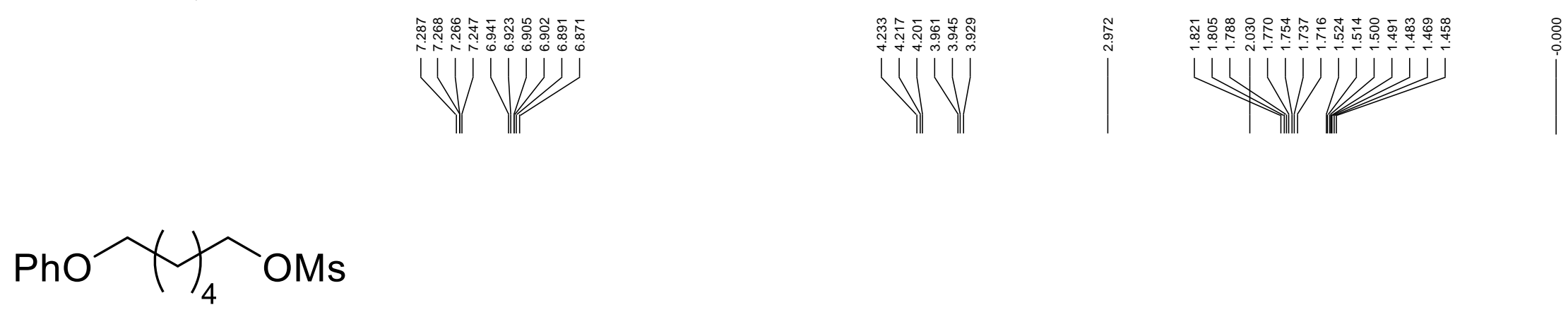

8j

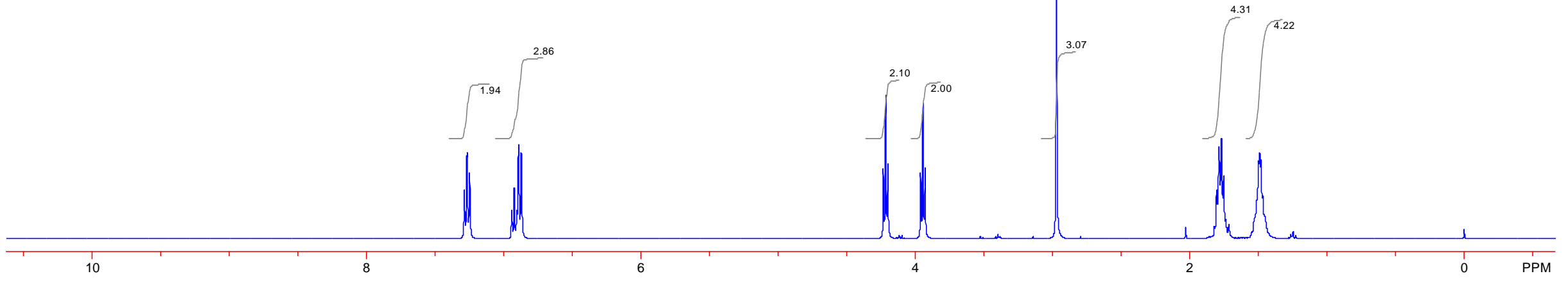


${ }^{13} \mathrm{C}$ NMR (100 MHz, CDCl3)

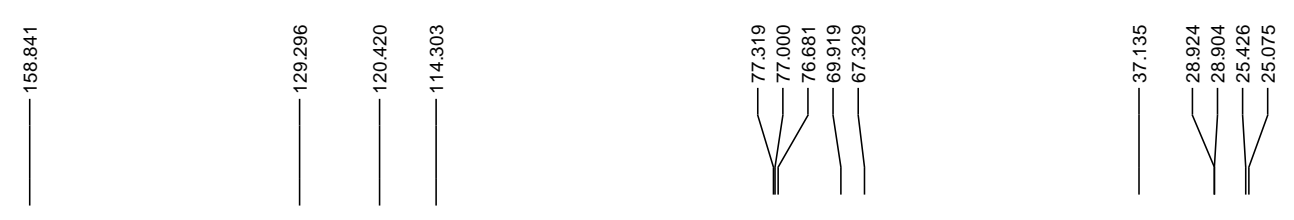

$$
\mathrm{PhO}_{\mathbf{8 j}} \mathrm{OMs}
$$

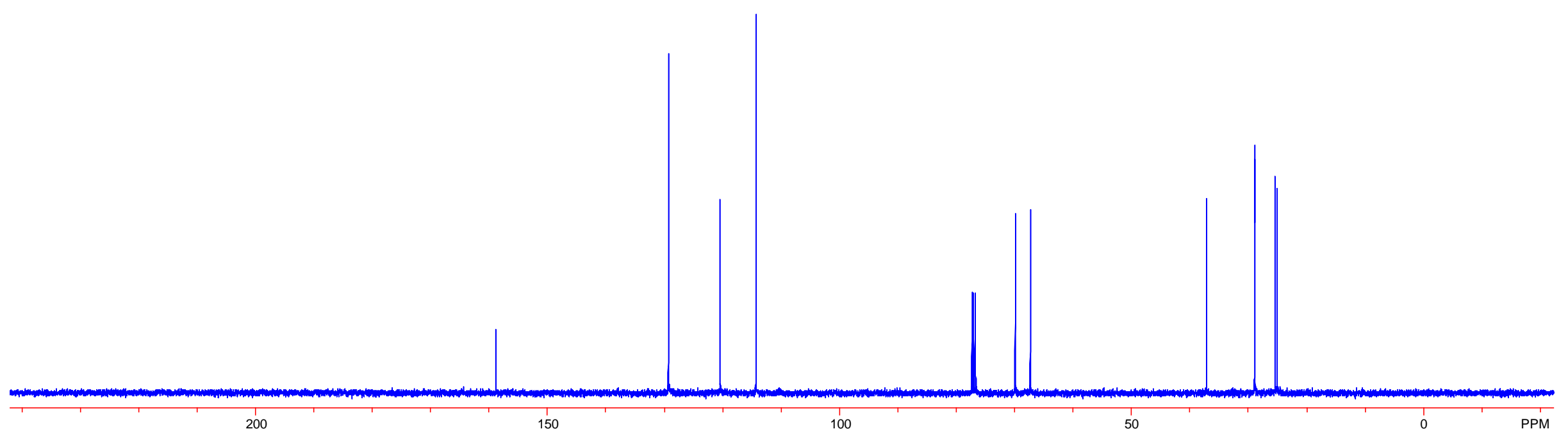


${ }^{1}$ H NMR (400 MHz, CDCl3)
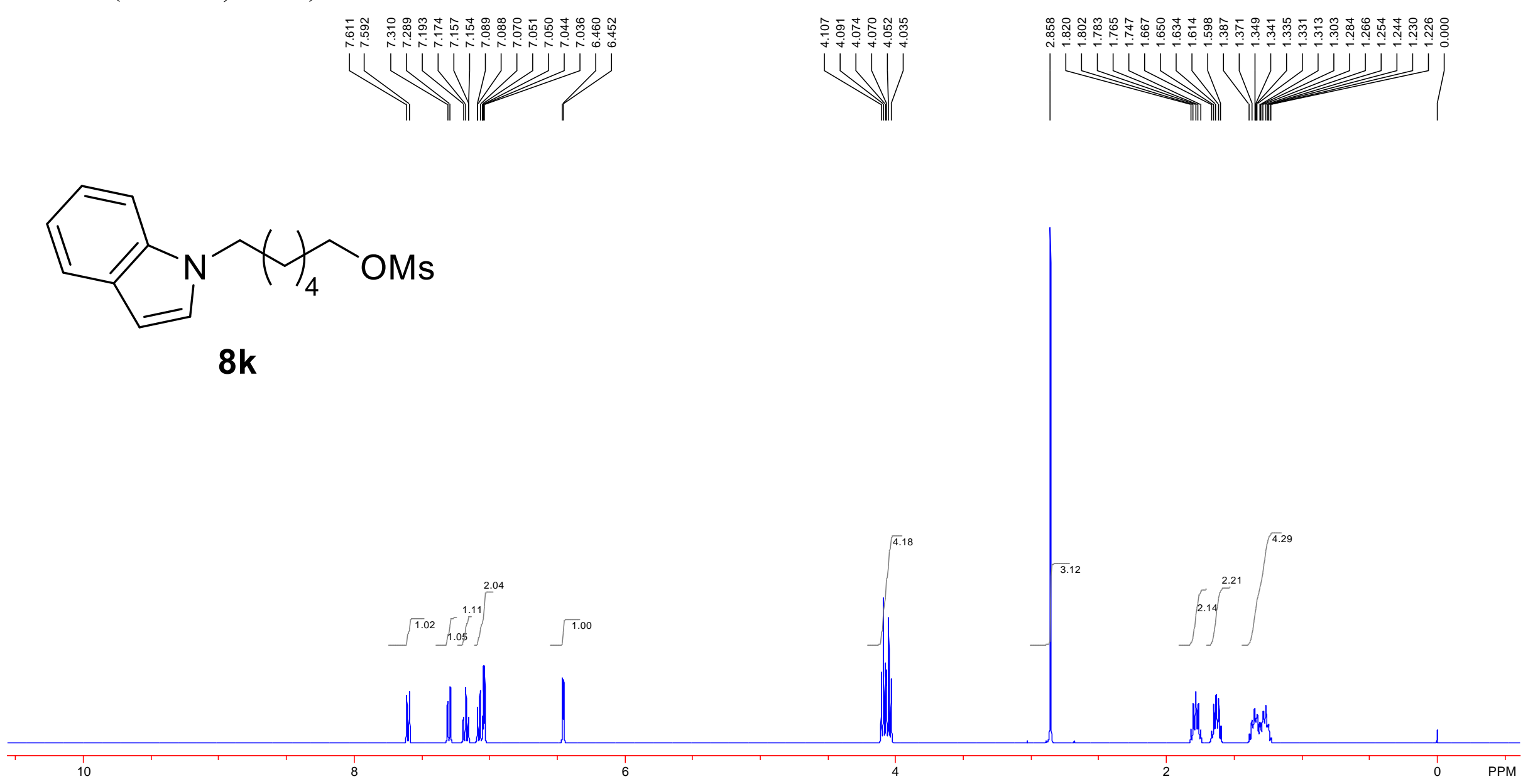
${ }^{13} \mathrm{C}$ NMR (100 MHz, CDCl3)
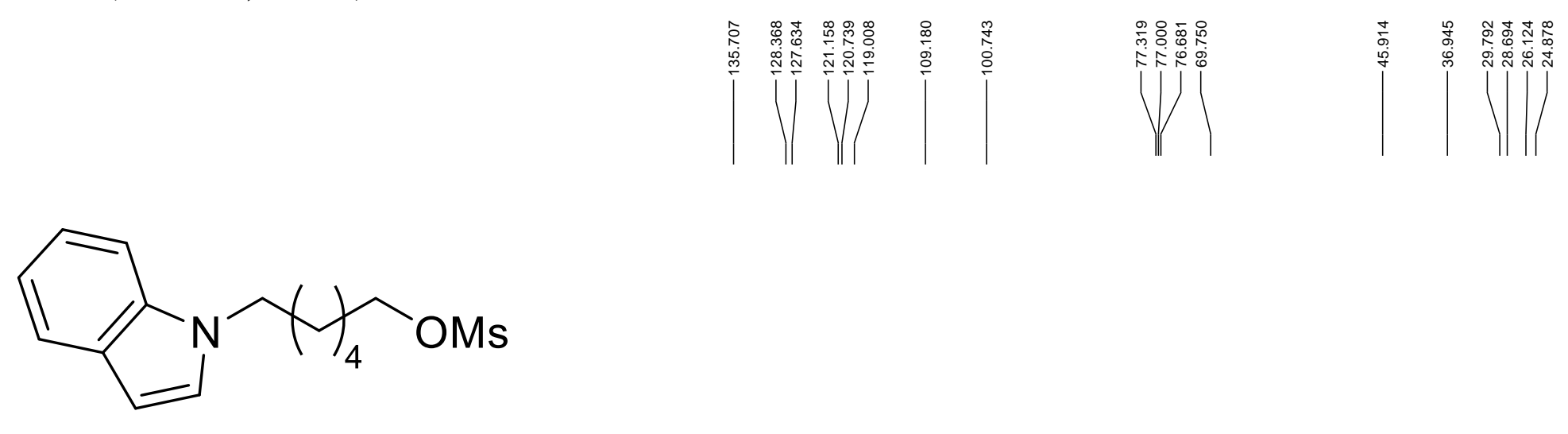

8k

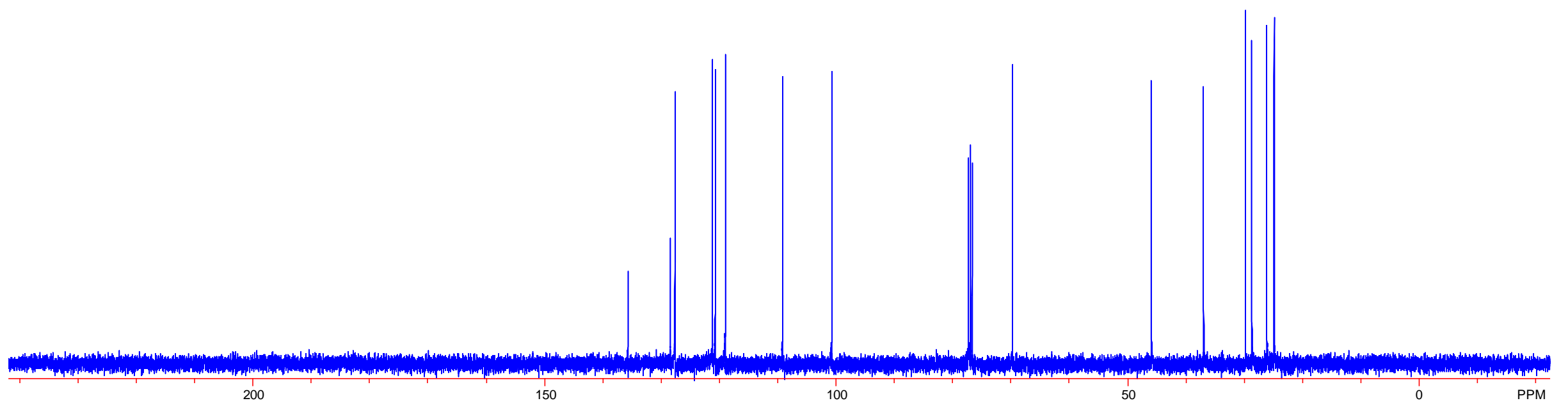


${ }^{1} \mathrm{H}$ NMR (400 MHz, CDCl3)

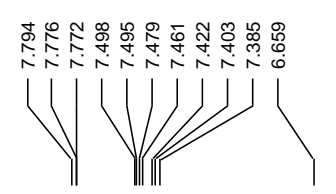

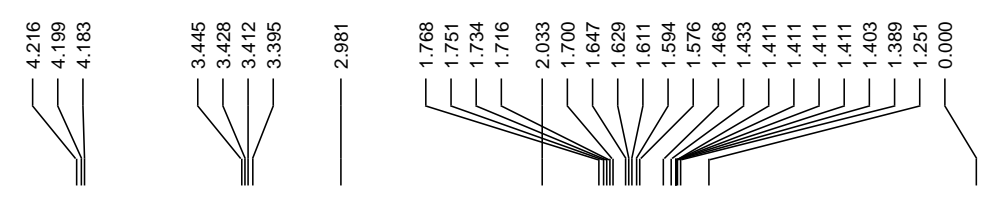<smiles>COCC(C)(C)CNC(=O)c1ccccc1</smiles>

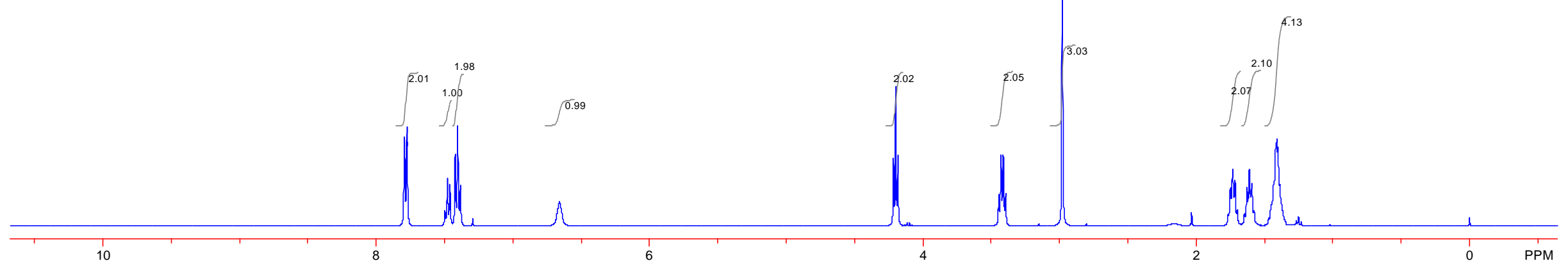


${ }^{13} \mathrm{C}$ NMR (100 MHz, CDCl3)
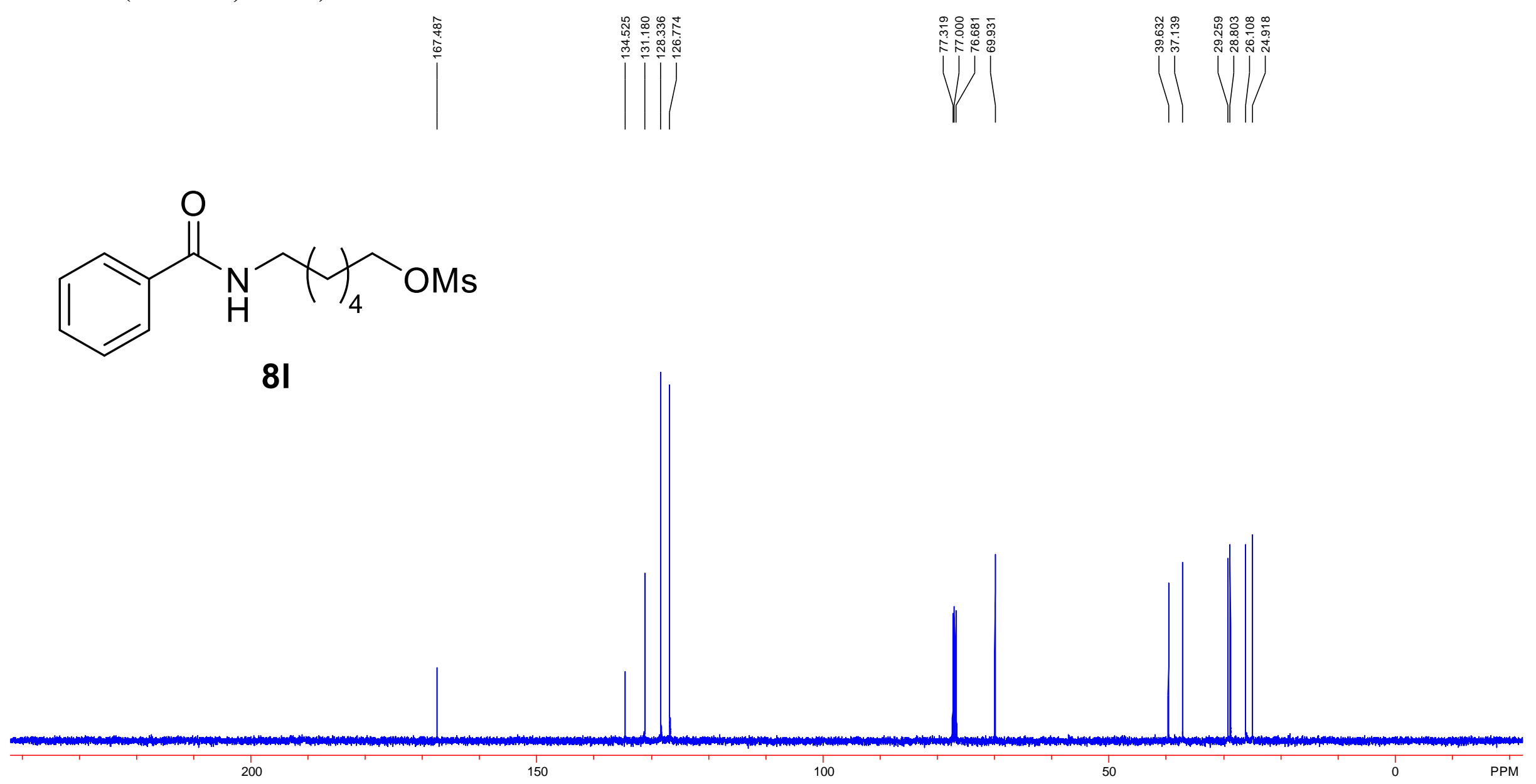
${ }^{1} \mathrm{H}$ NMR (400 MHz, CDCl3)
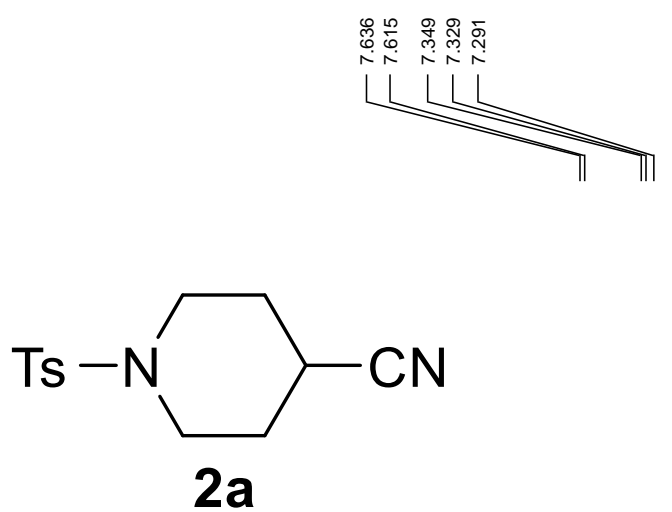

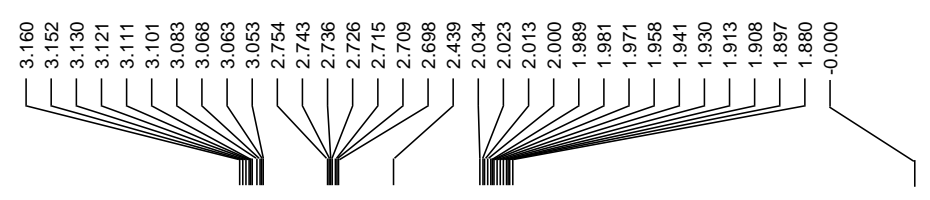

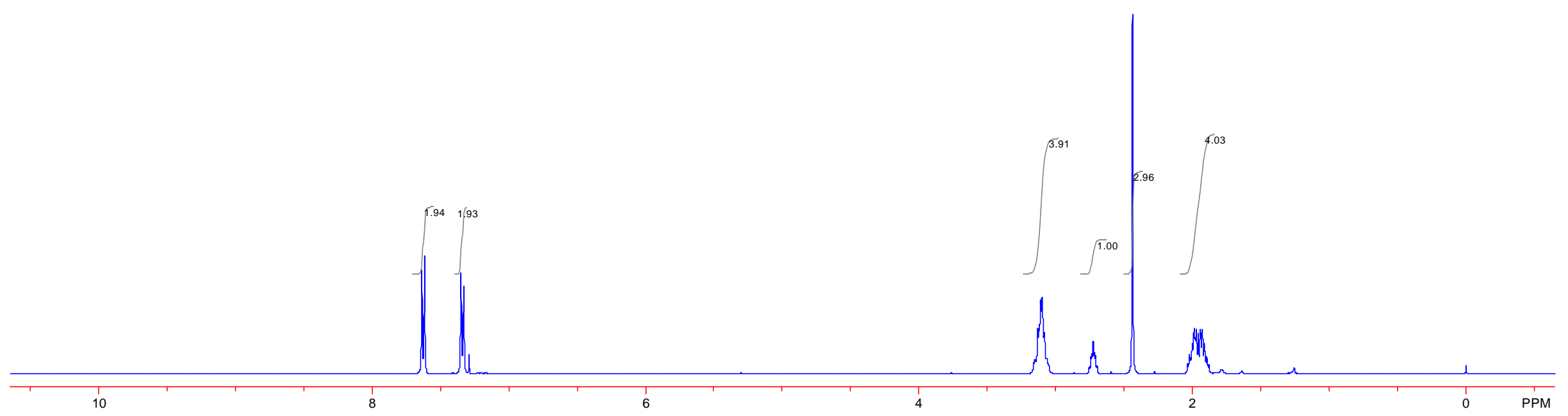


${ }^{13} \mathrm{C}$ NMR (100 MHz, CDCl3)
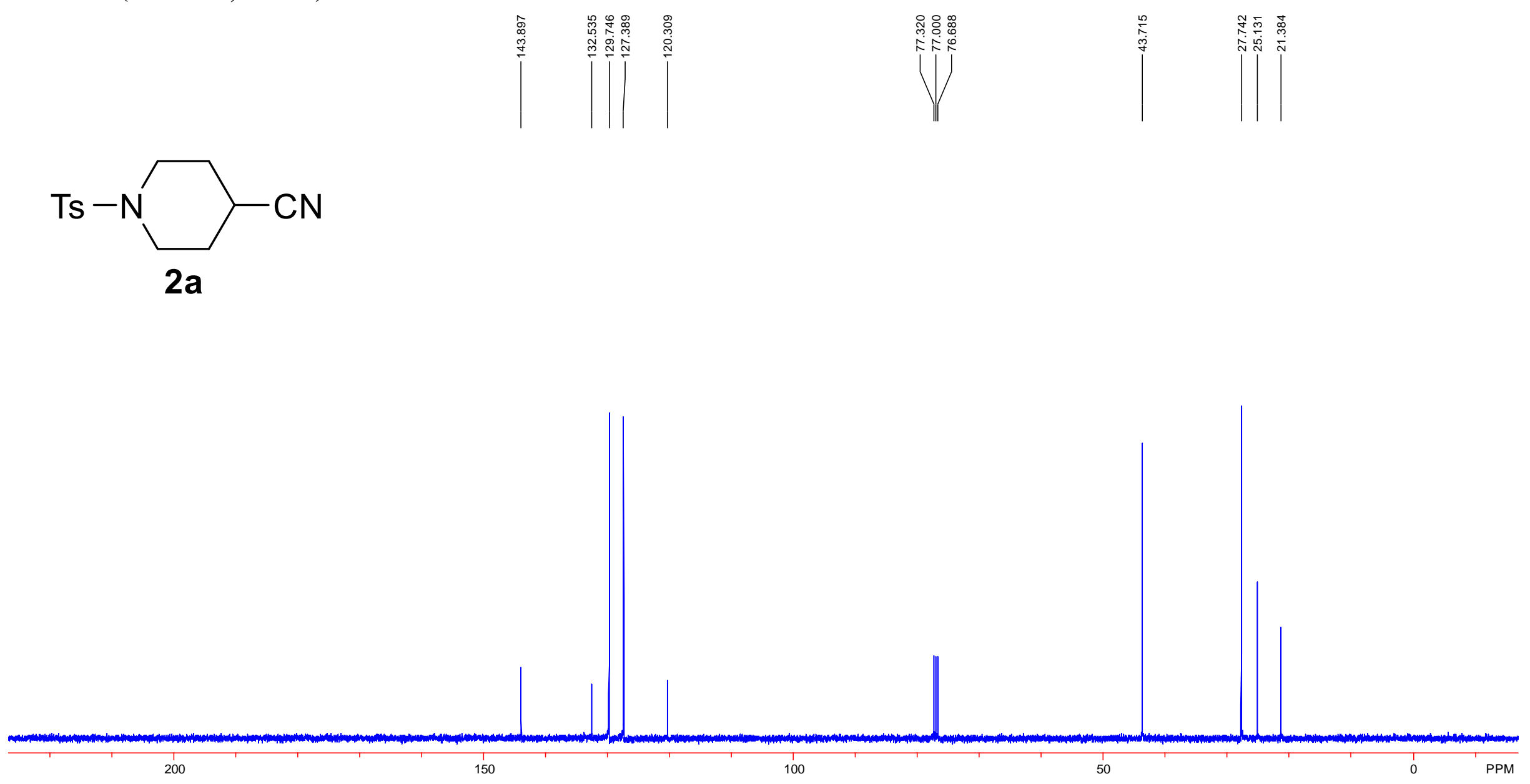
${ }^{1}$ H NMR (400 MHz, CDCl3)

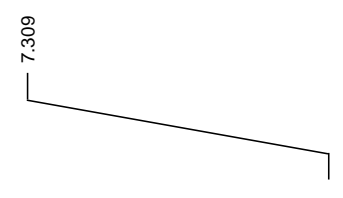

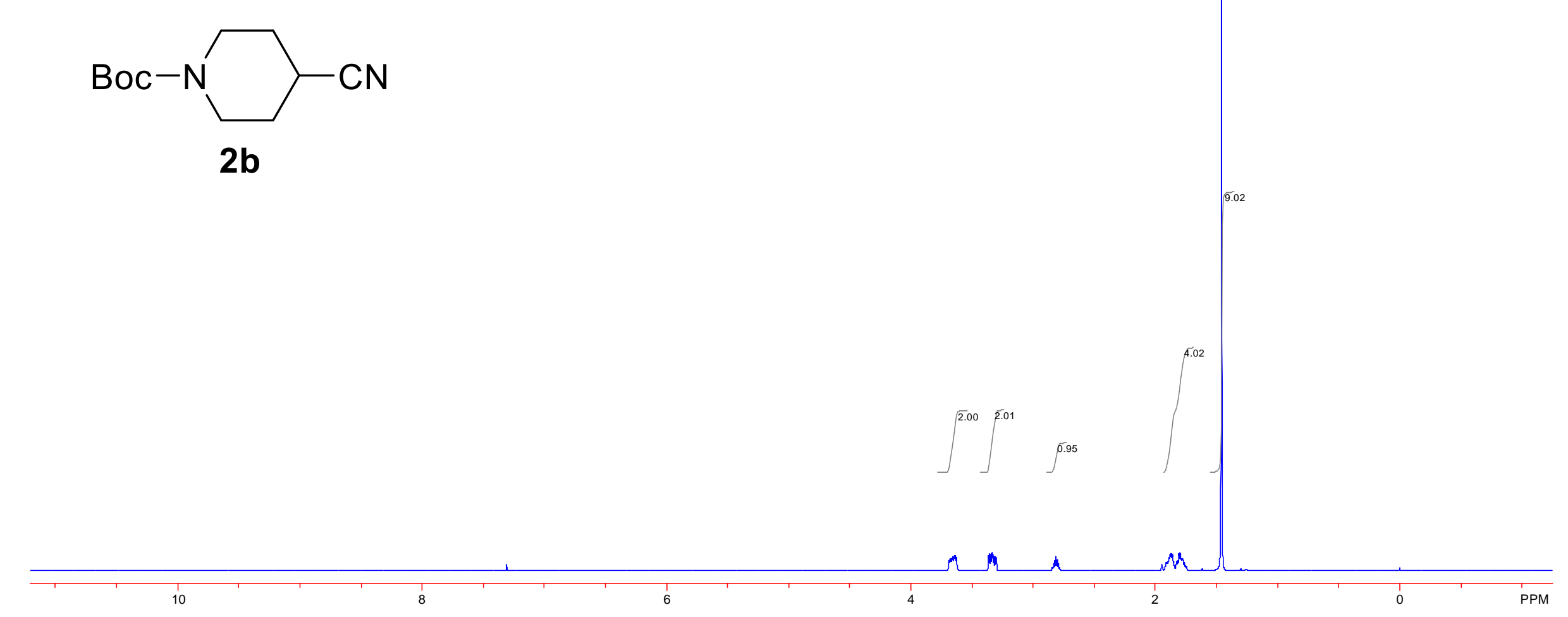

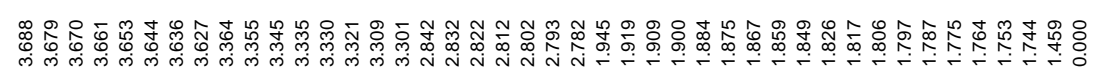

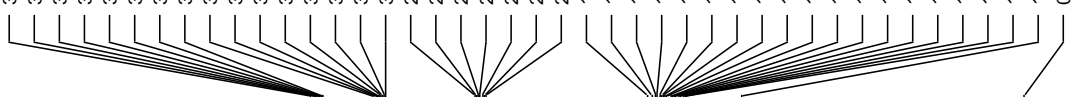


${ }^{13} \mathrm{C}$ NMR (100 MHz, CDCl3)
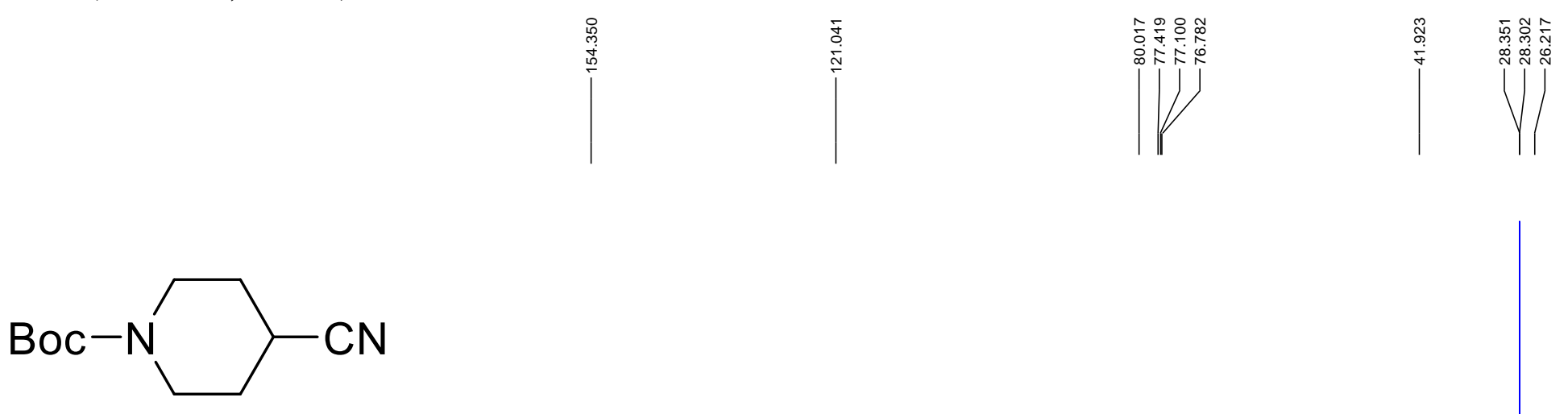

2b 
${ }^{1}$ H NMR (400 MHz, CDCl3)

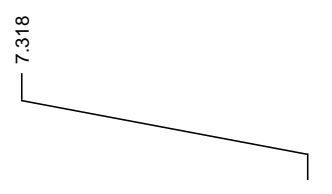

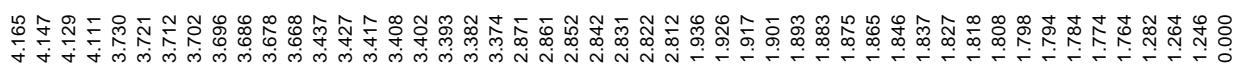

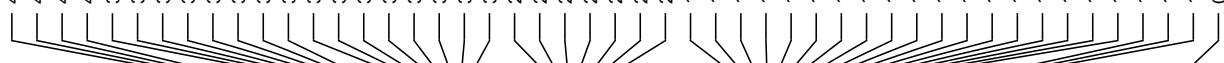
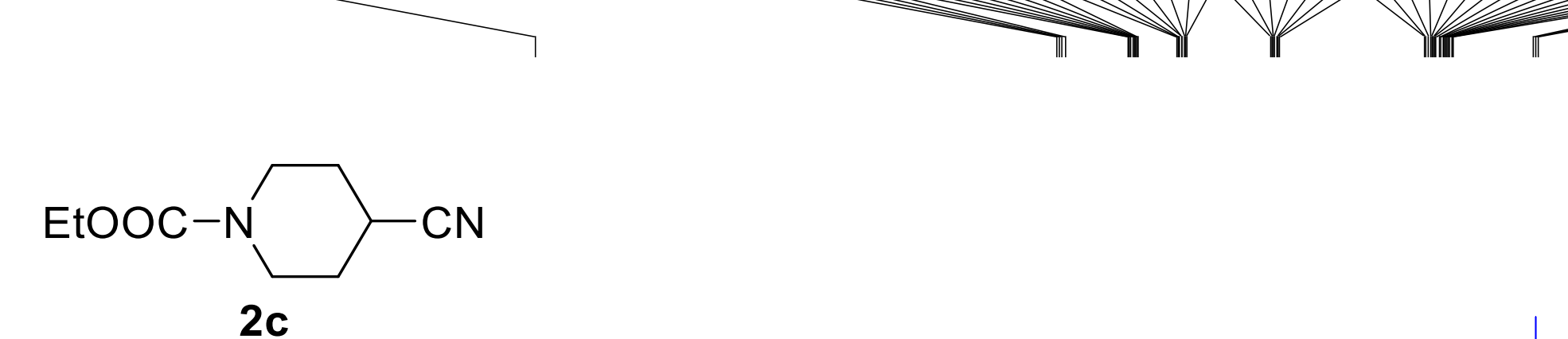

\section{2c}

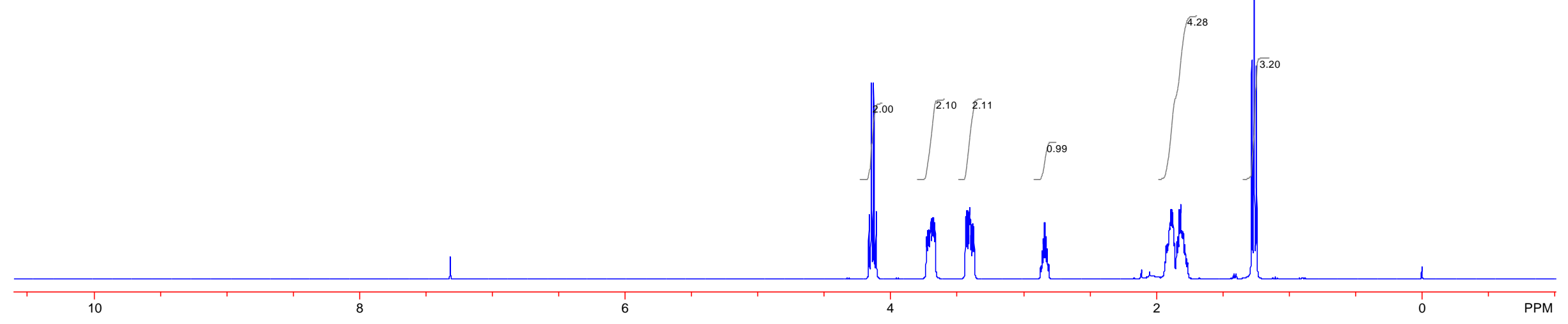


${ }^{13} \mathrm{C}$ NMR (100 MHz, CDCl3)
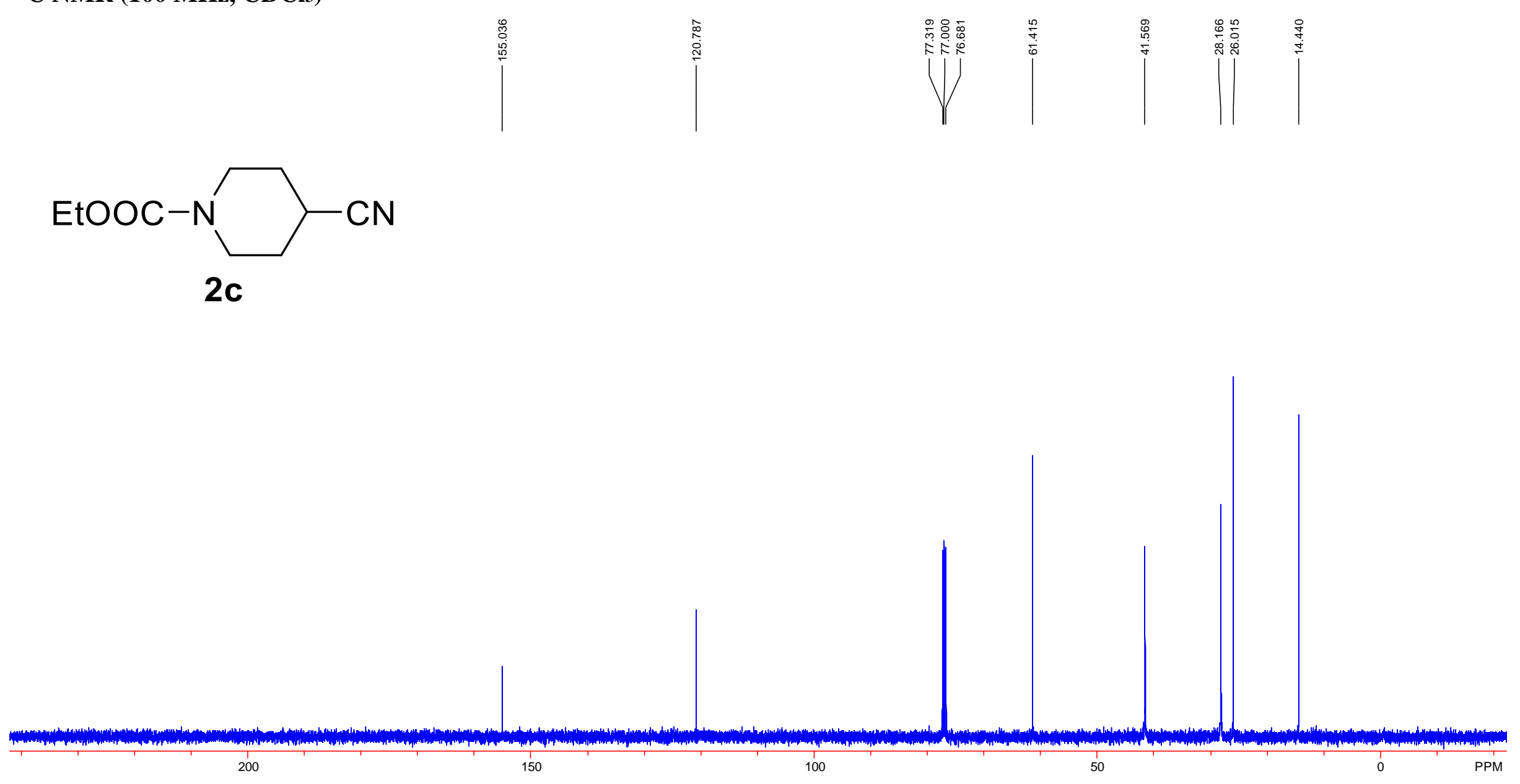
${ }^{1}$ H NMR (400 MHz, CDCl3)

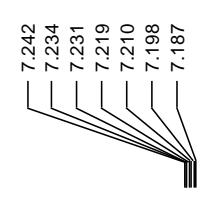

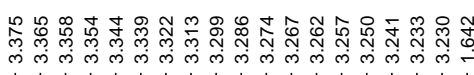

4464UHU10]

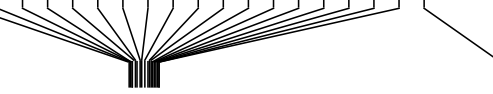<smiles>N#CC1Cc2ccccc2C1</smiles>

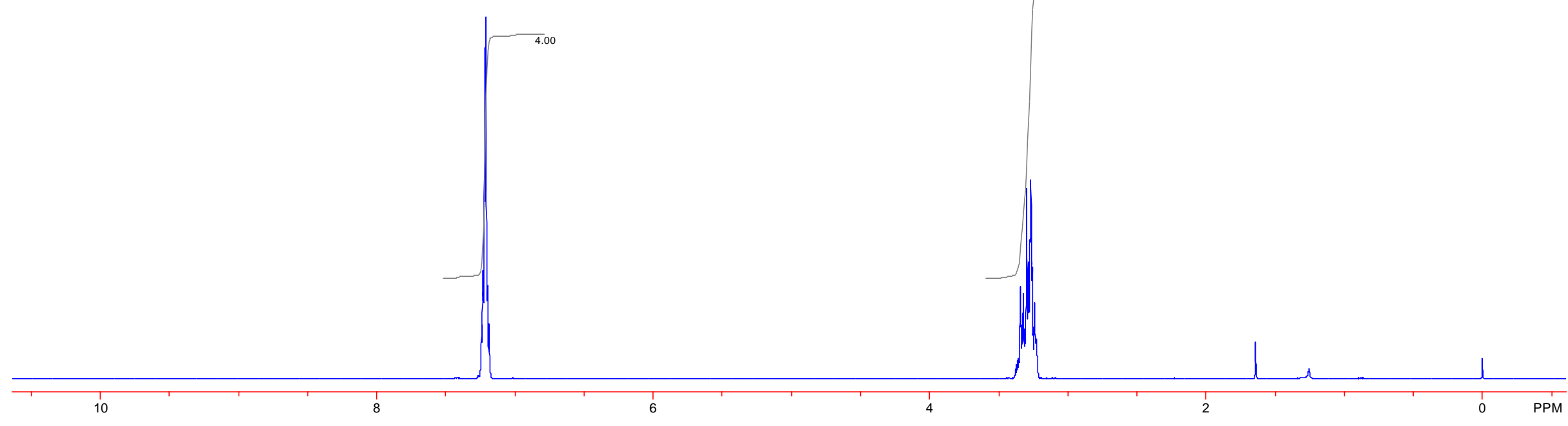


${ }^{13} \mathrm{C}$ NMR (100 MHz, CDCl3)

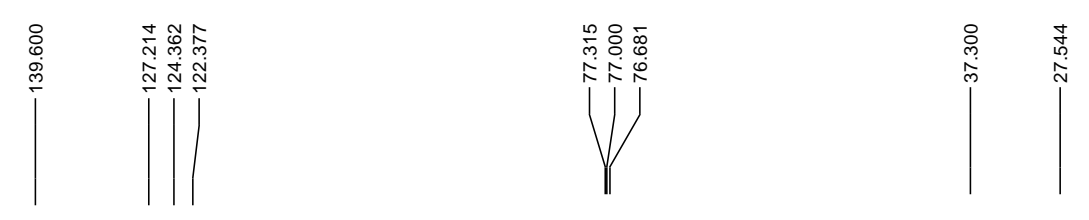<smiles>N#CC1Cc2ccccc2C1</smiles>

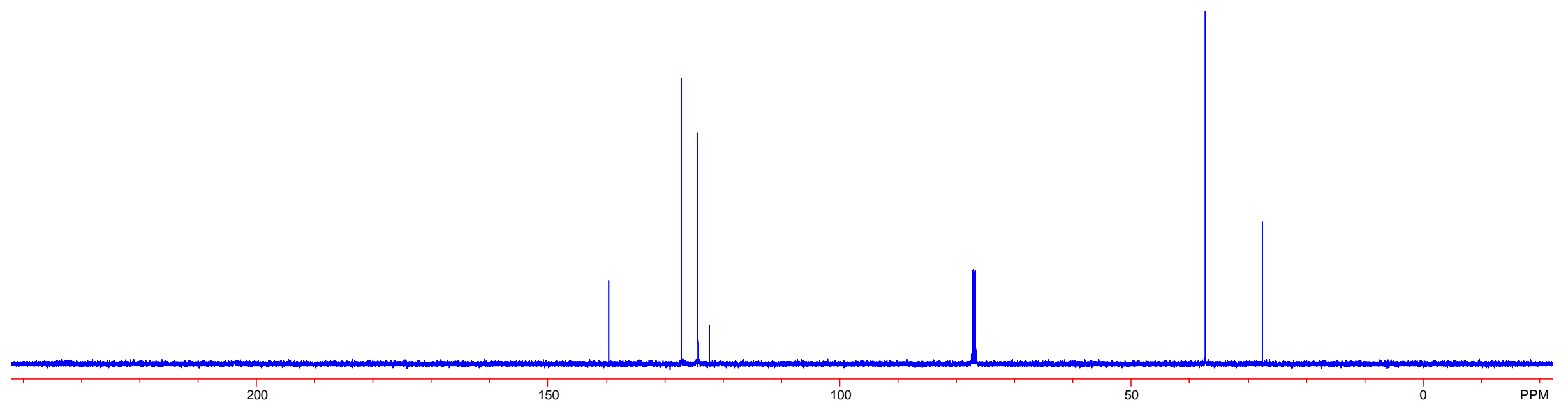


${ }^{1}$ H NMR (400 MHz, CDCl3)

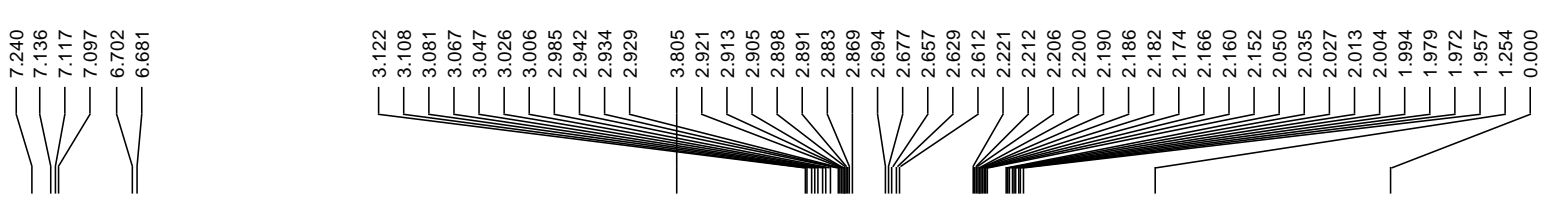<smiles>COc1cccc2c1CCC(C#N)C2</smiles>

$2 e$ 
${ }^{13} \mathrm{C}$ NMR (100 MHz, CDCl3)
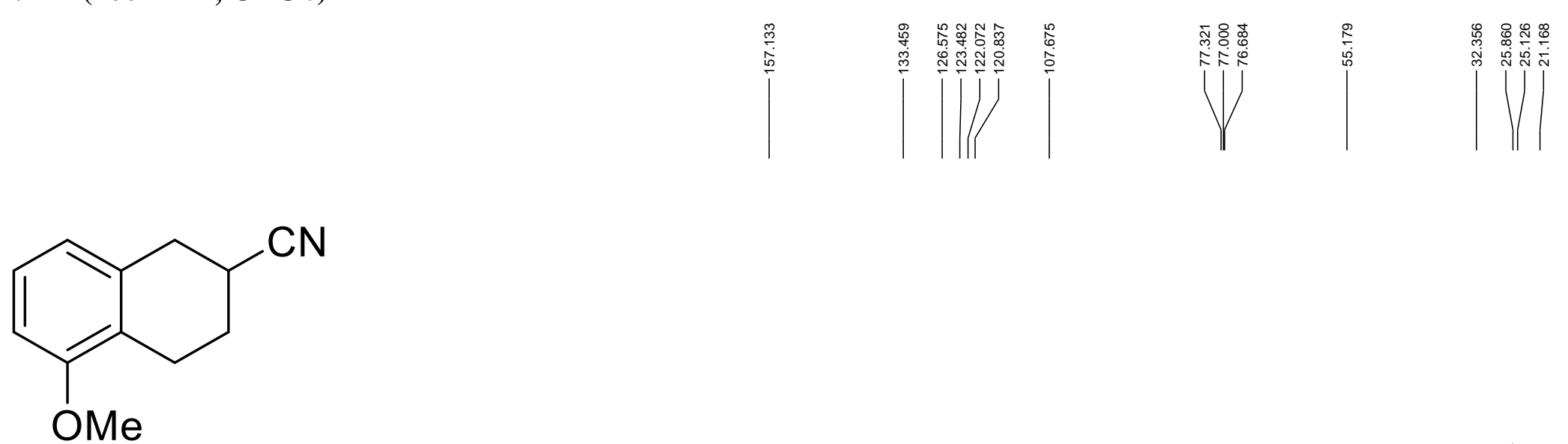

$2 e$ 
${ }^{1}$ H NMR (400 MHz, CDCl3)

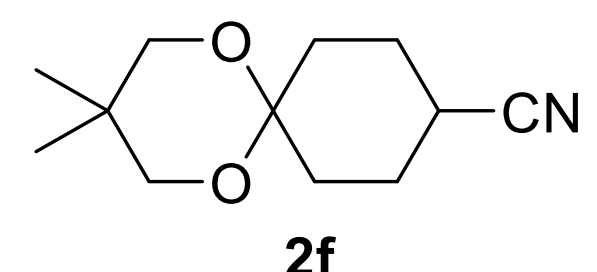

\section{$2 f$}


${ }^{13} \mathrm{C}$ NMR (100 MHz, CDCl3)
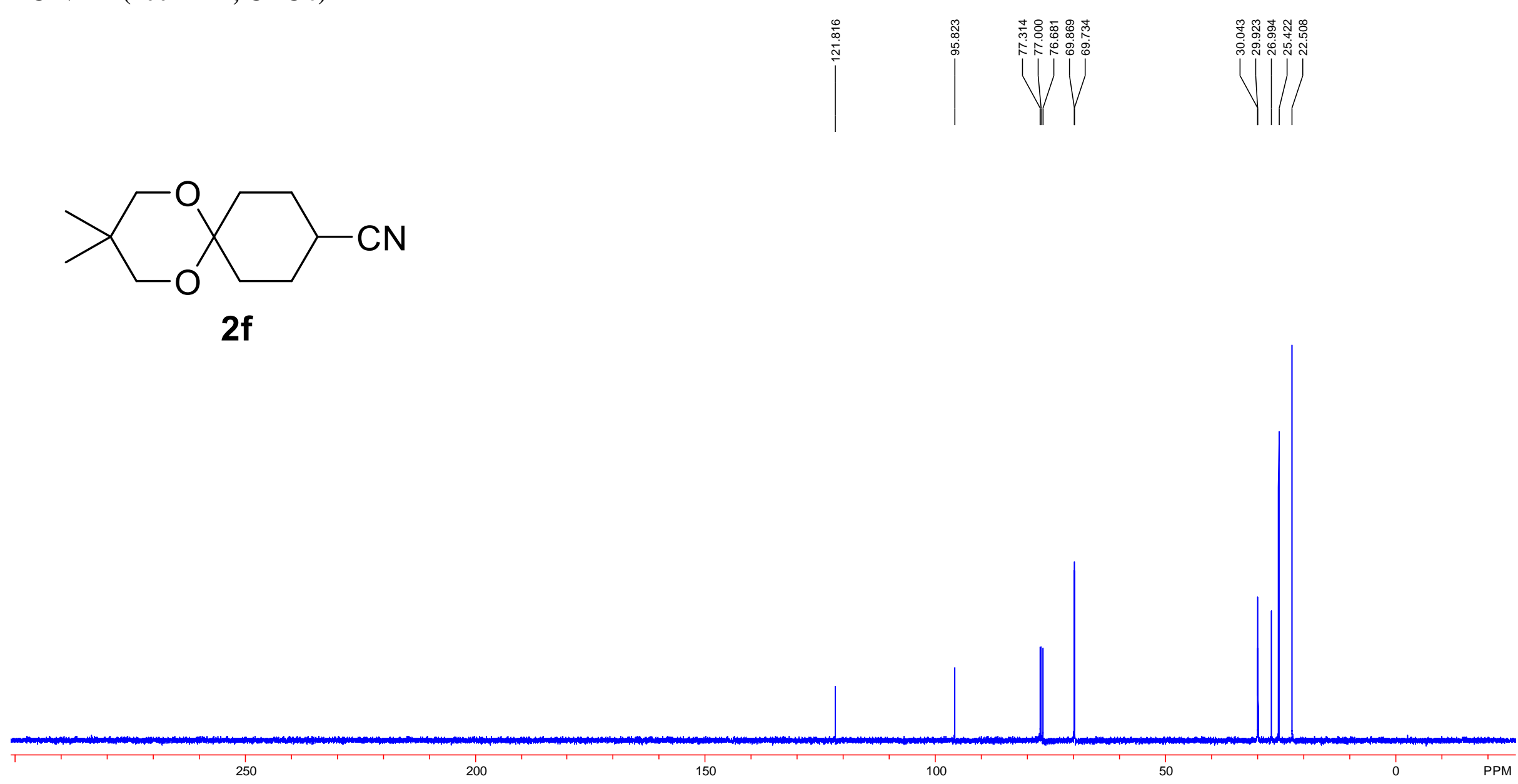
${ }^{1}$ H NMR (400 MHz, CDCl3)
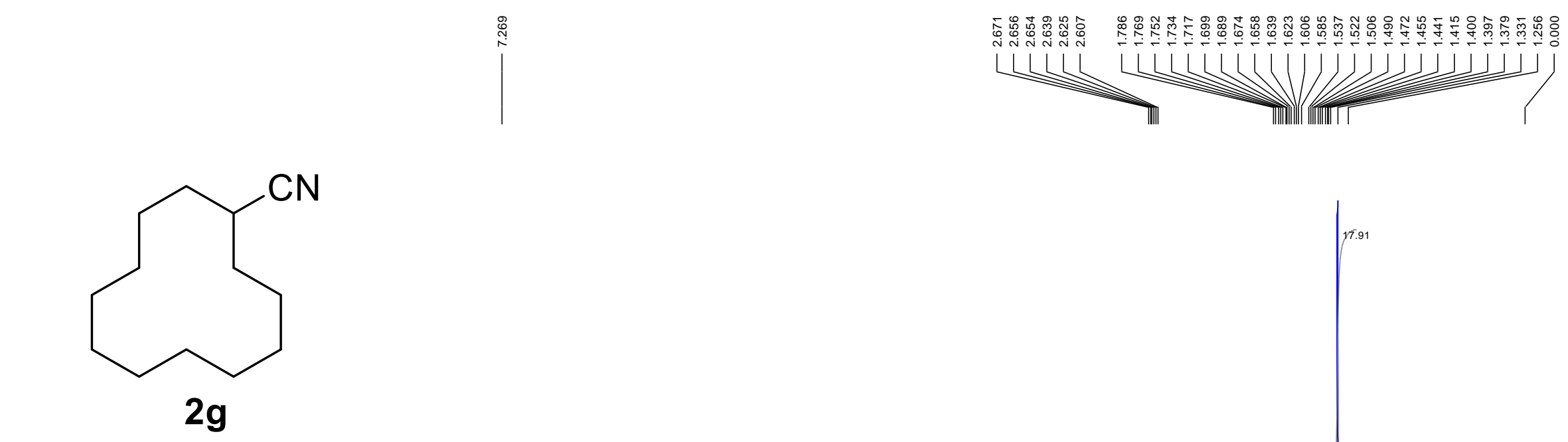

$$
\mid
$$
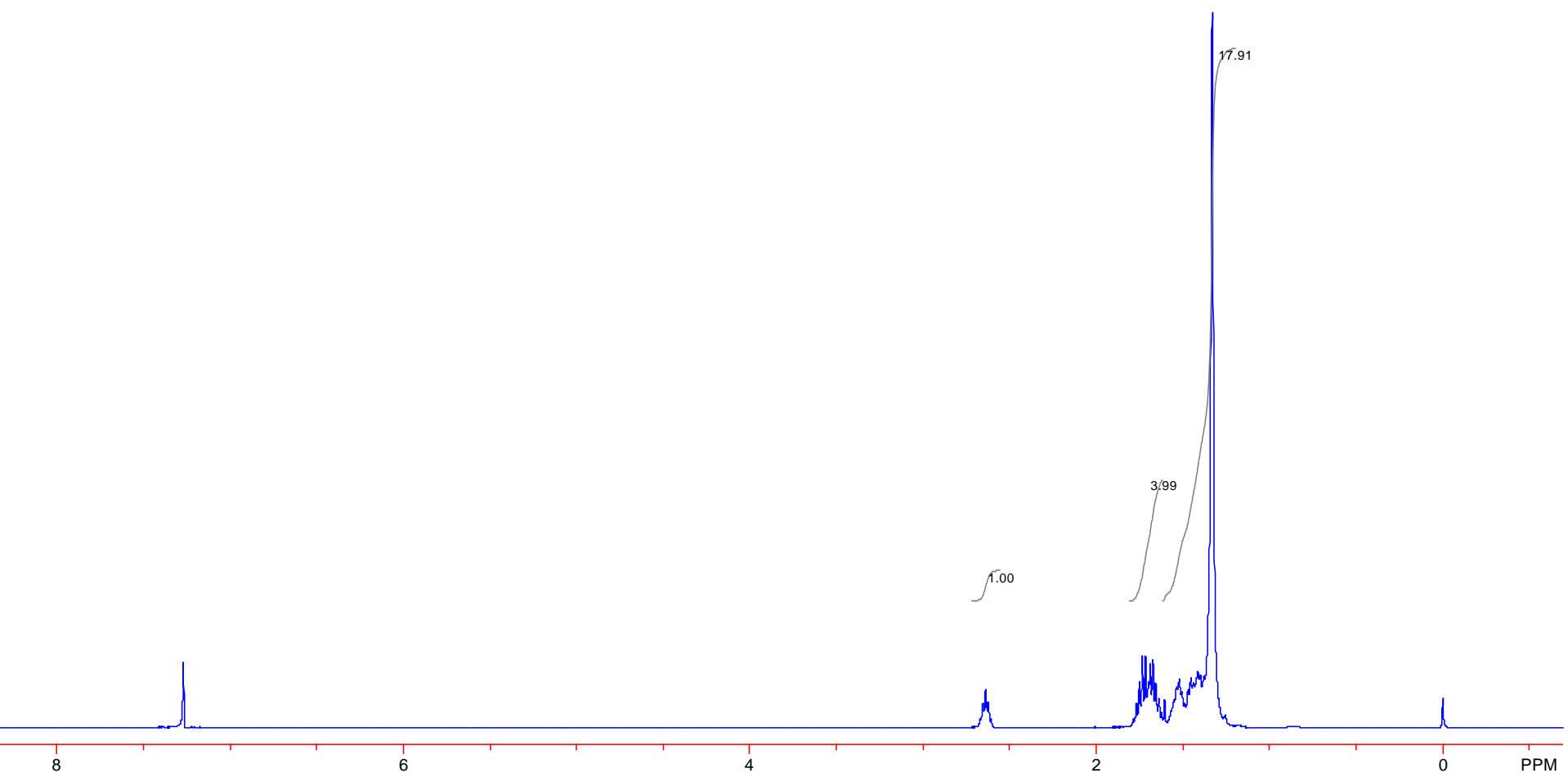
${ }^{13} \mathrm{C}$ NMR (100 MHz, CDCl3)
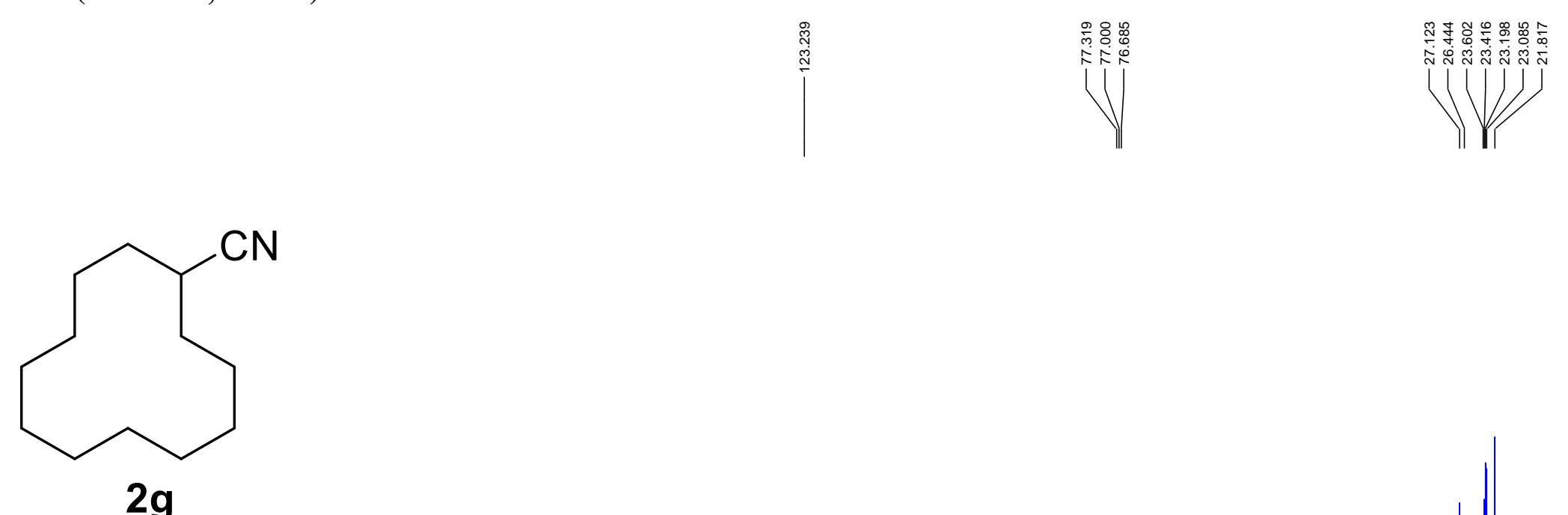
${ }^{1}$ H NMR (400 MHz, CDCl3)

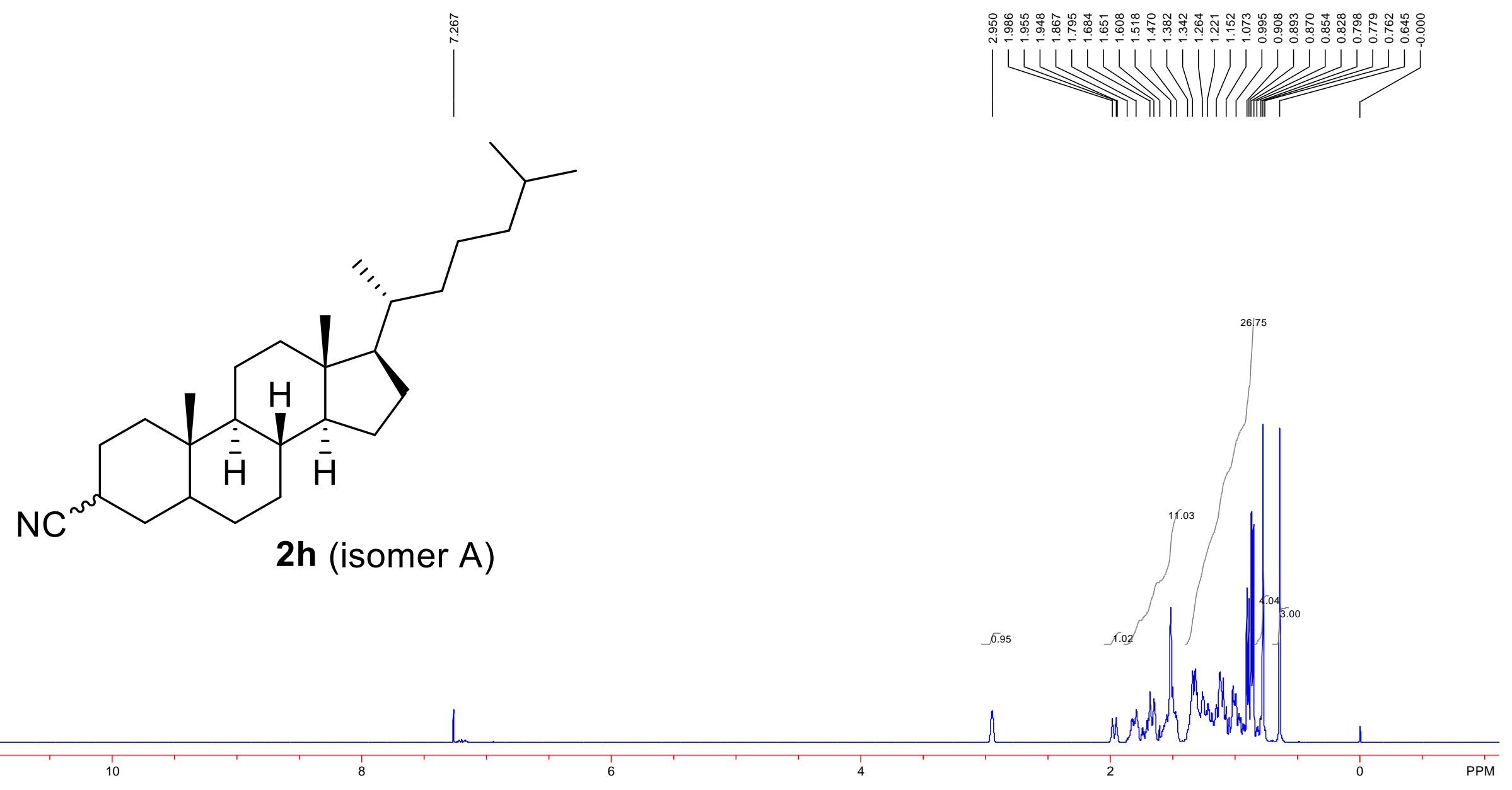


${ }^{13} \mathrm{C}$ NMR (100 MHz, CDCl3)

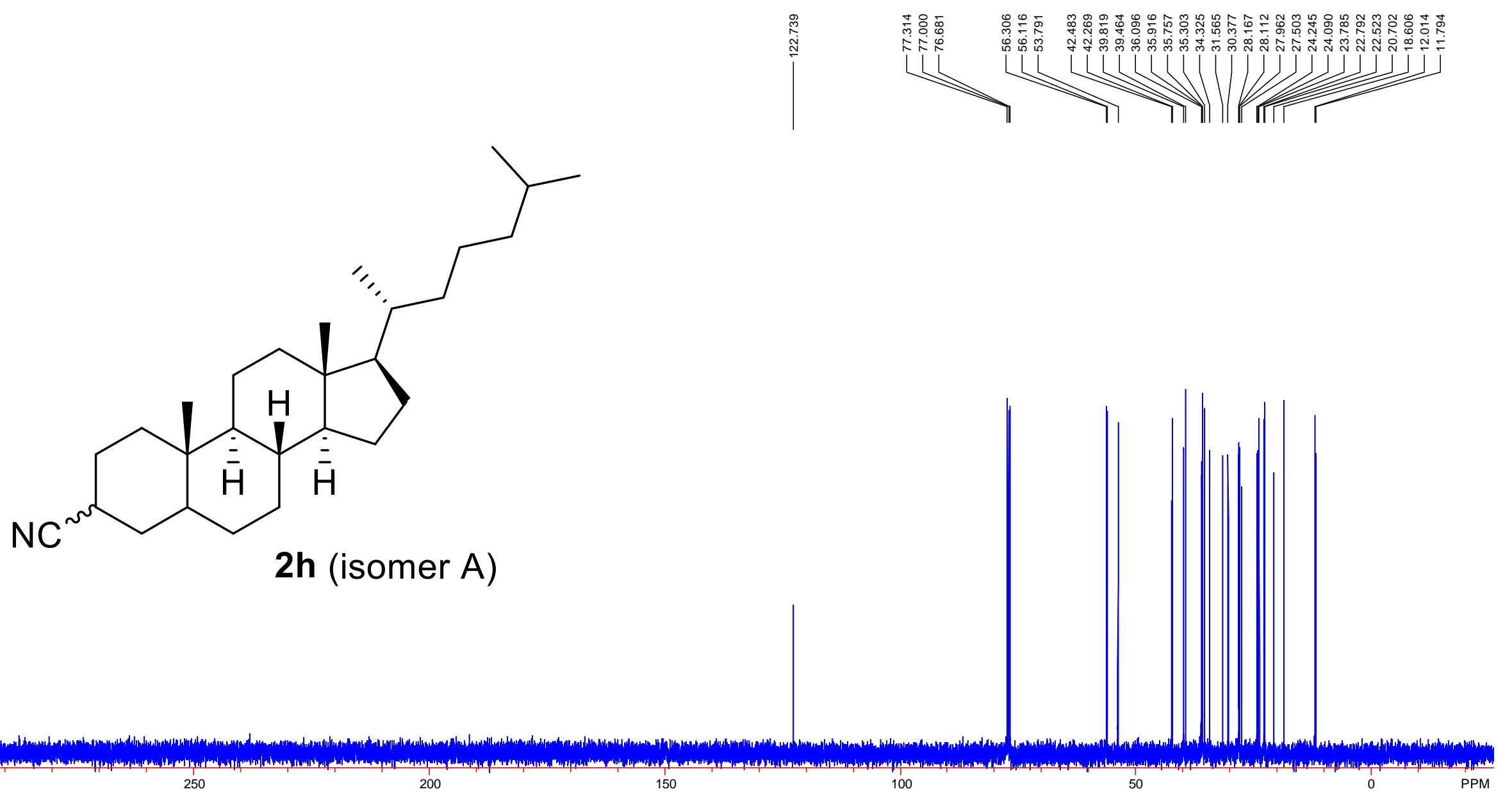


${ }^{1}$ H NMR (400 MHz, CDCl3)

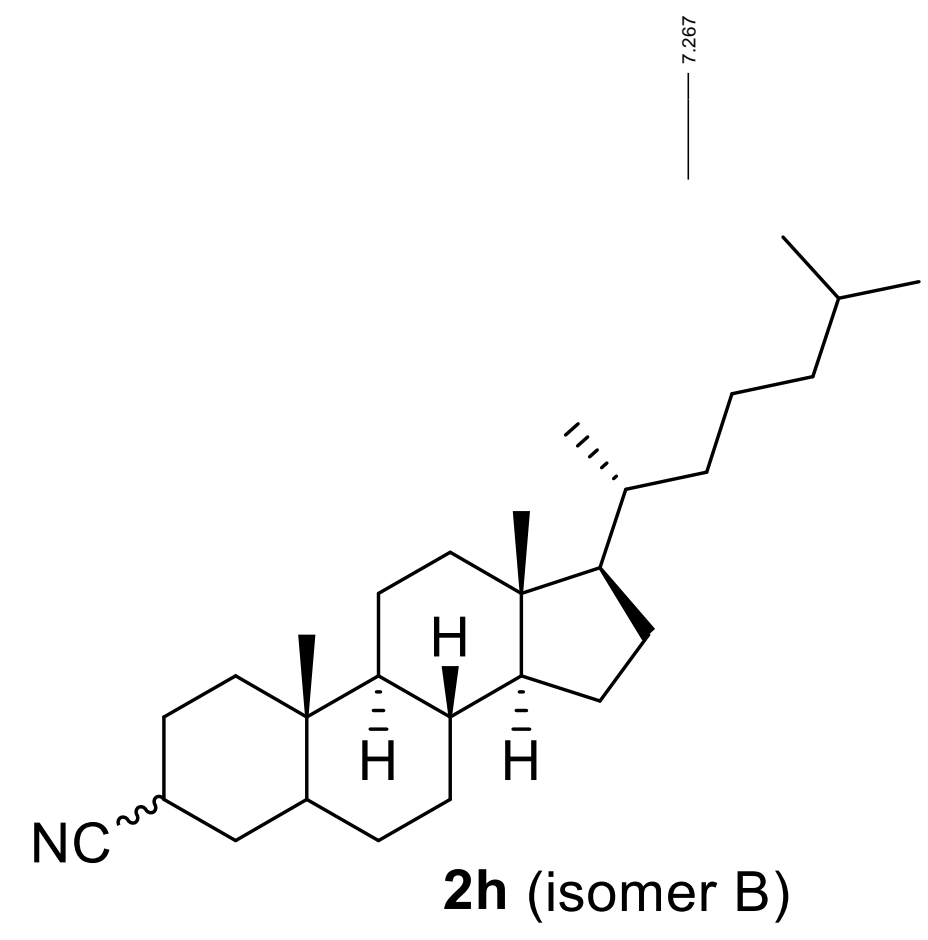

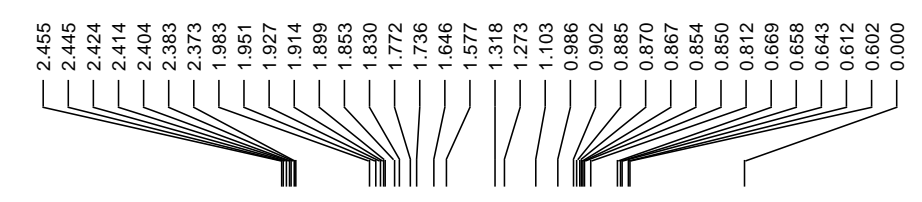

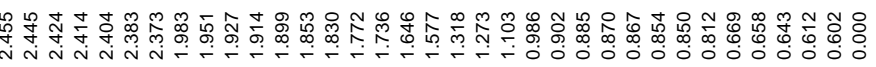

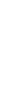

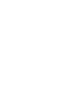


${ }^{13} \mathrm{C}$ NMR (100 MHz, CDCl3)
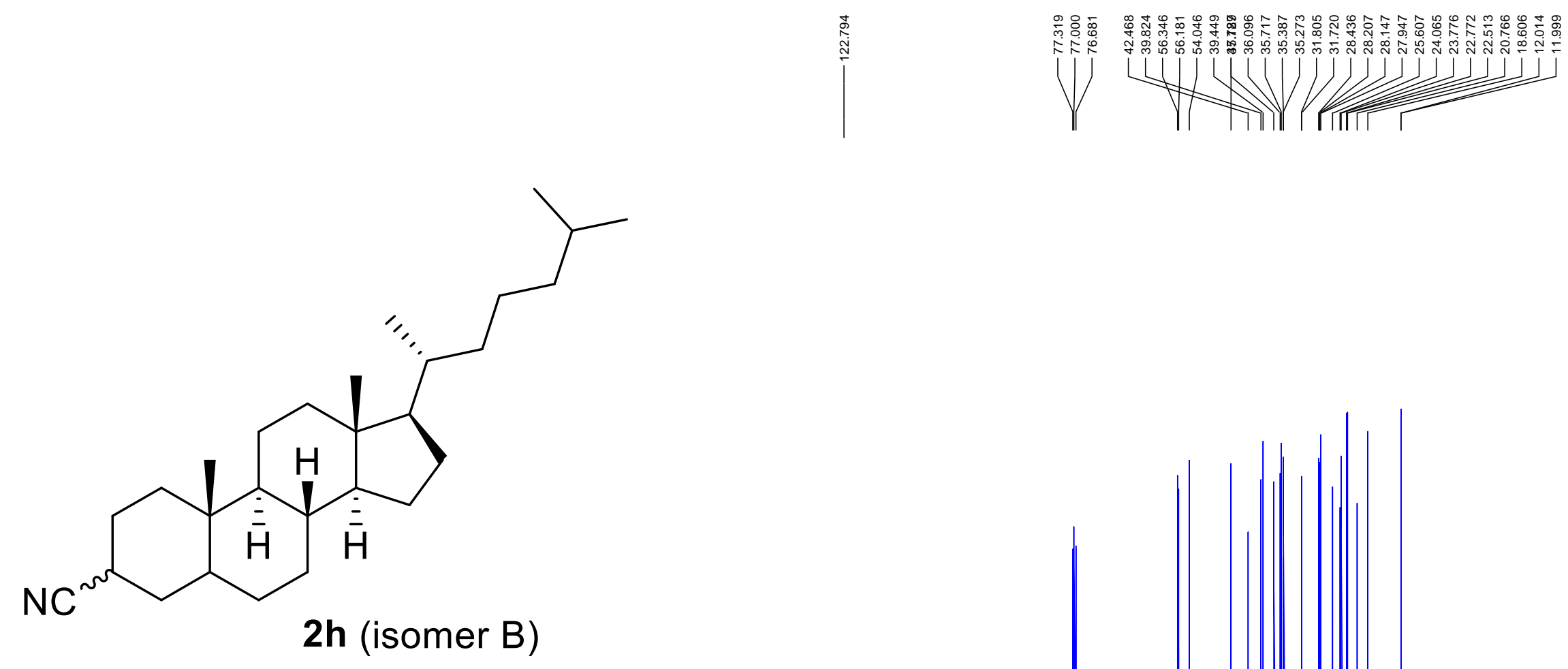
${ }^{1} \mathrm{H}$ NMR (400 MHz, CDCl3)

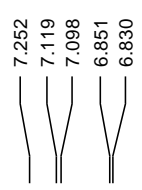

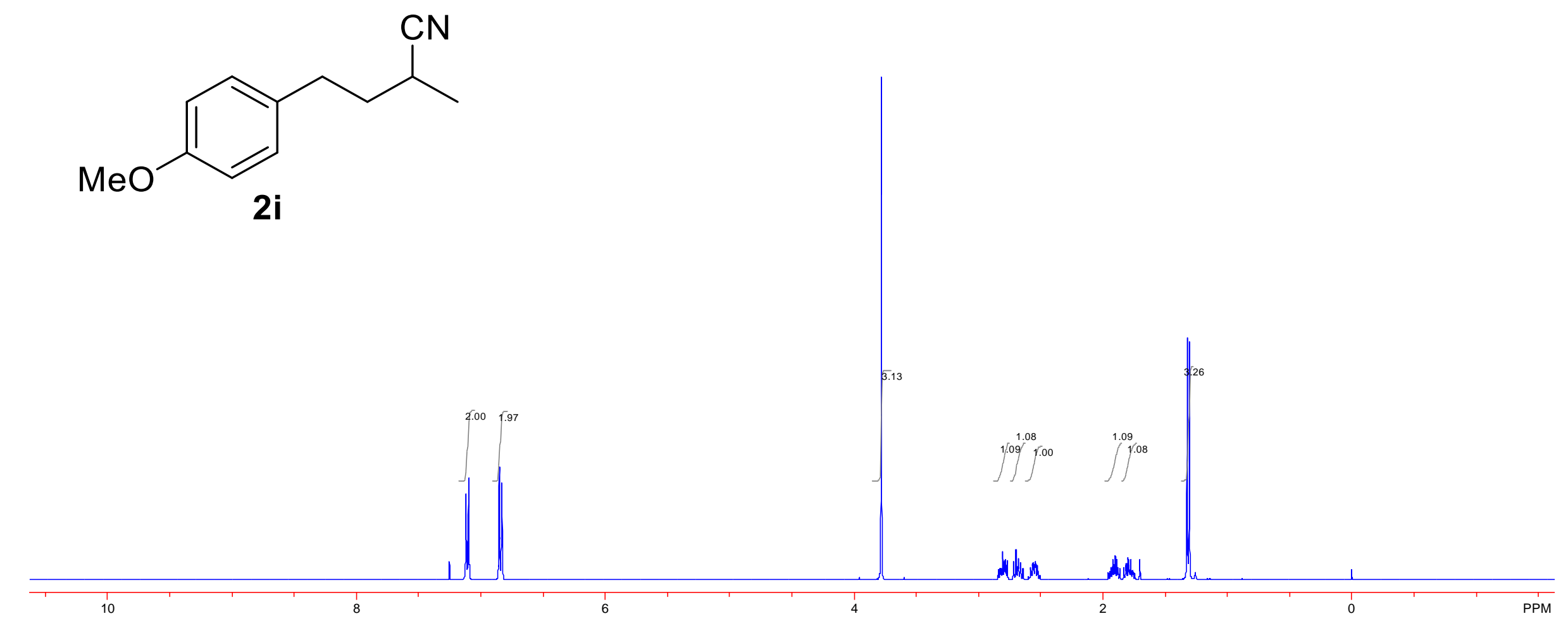

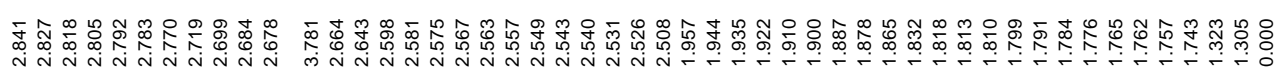

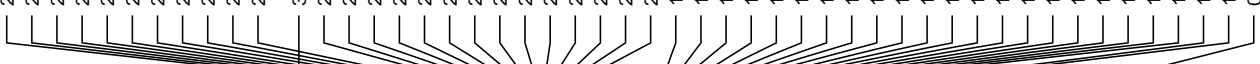

1IIIIII

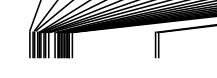


${ }^{13} \mathrm{C}$ NMR (100 MHz, CDCl3)
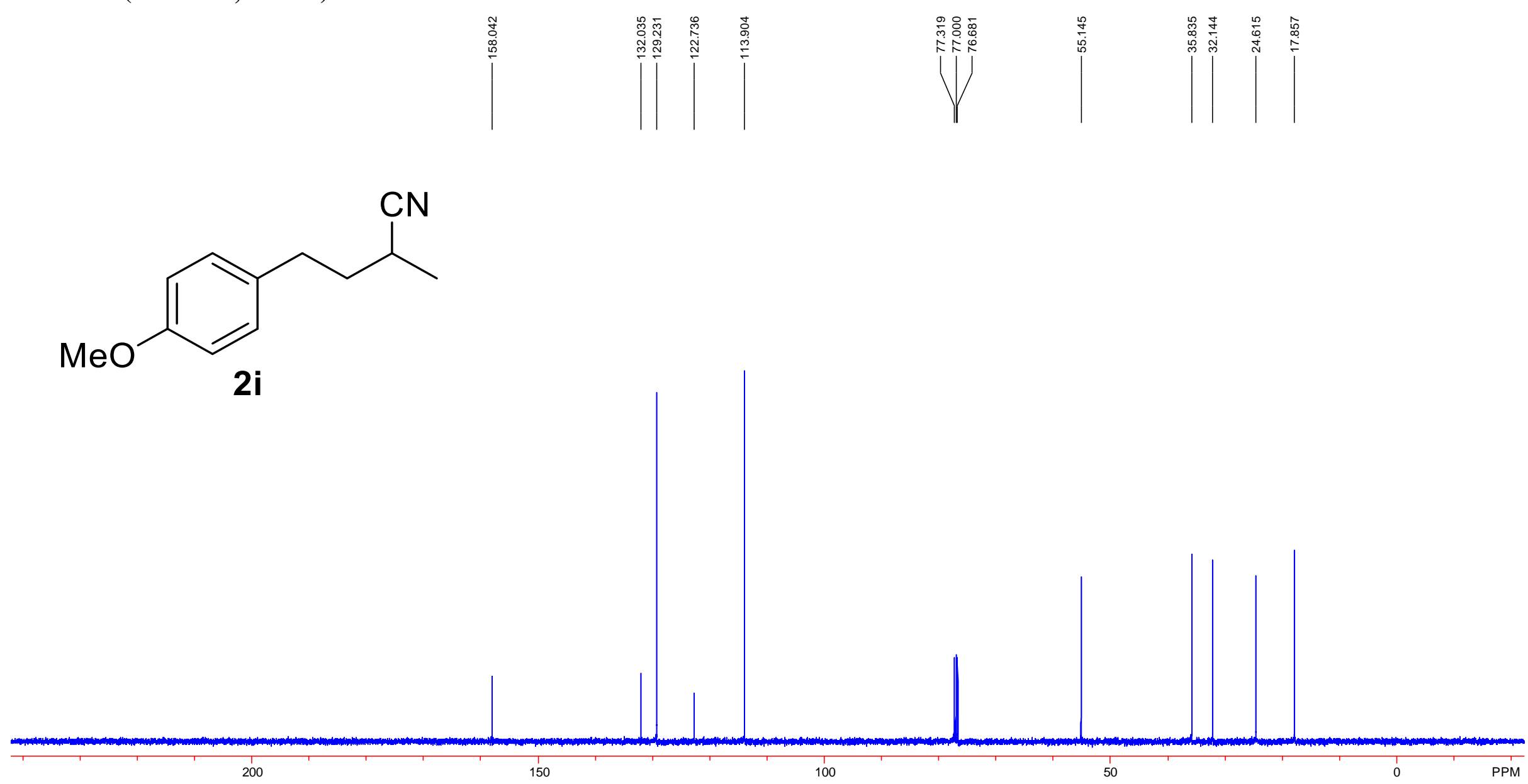
${ }^{1}$ H NMR (400 MHz, CDCl3)

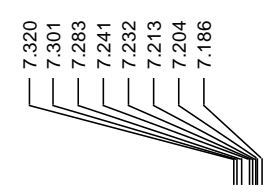<smiles>CCCC(C#N)CCc1ccccc1</smiles>

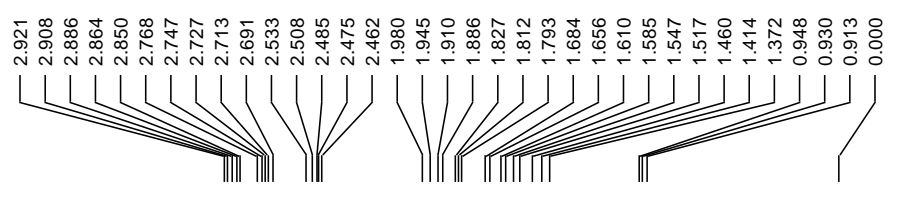

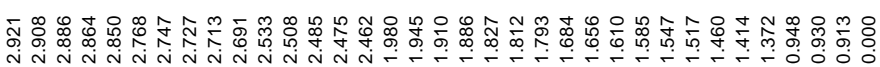

这U

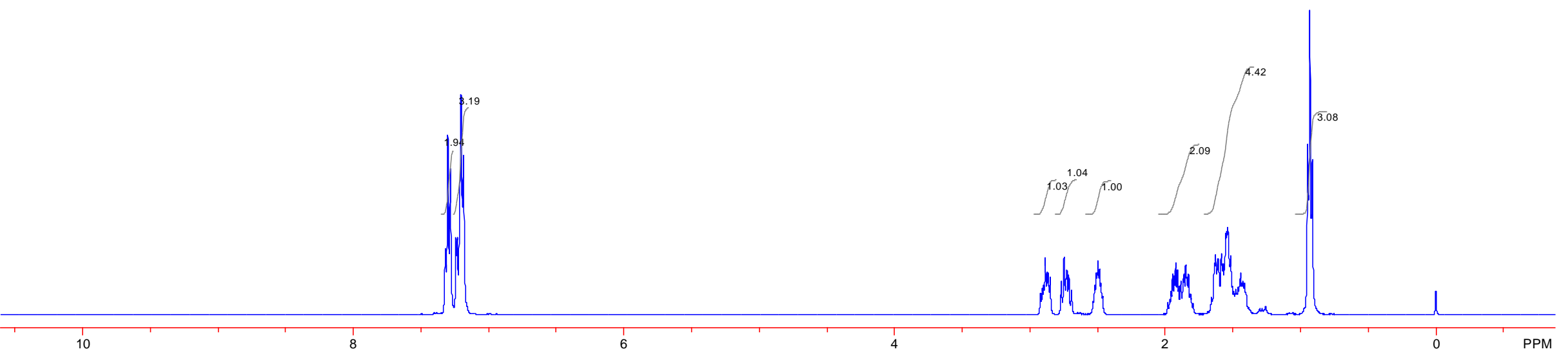


${ }^{13} \mathrm{C}$ NMR (100 MHz, CDCl3)
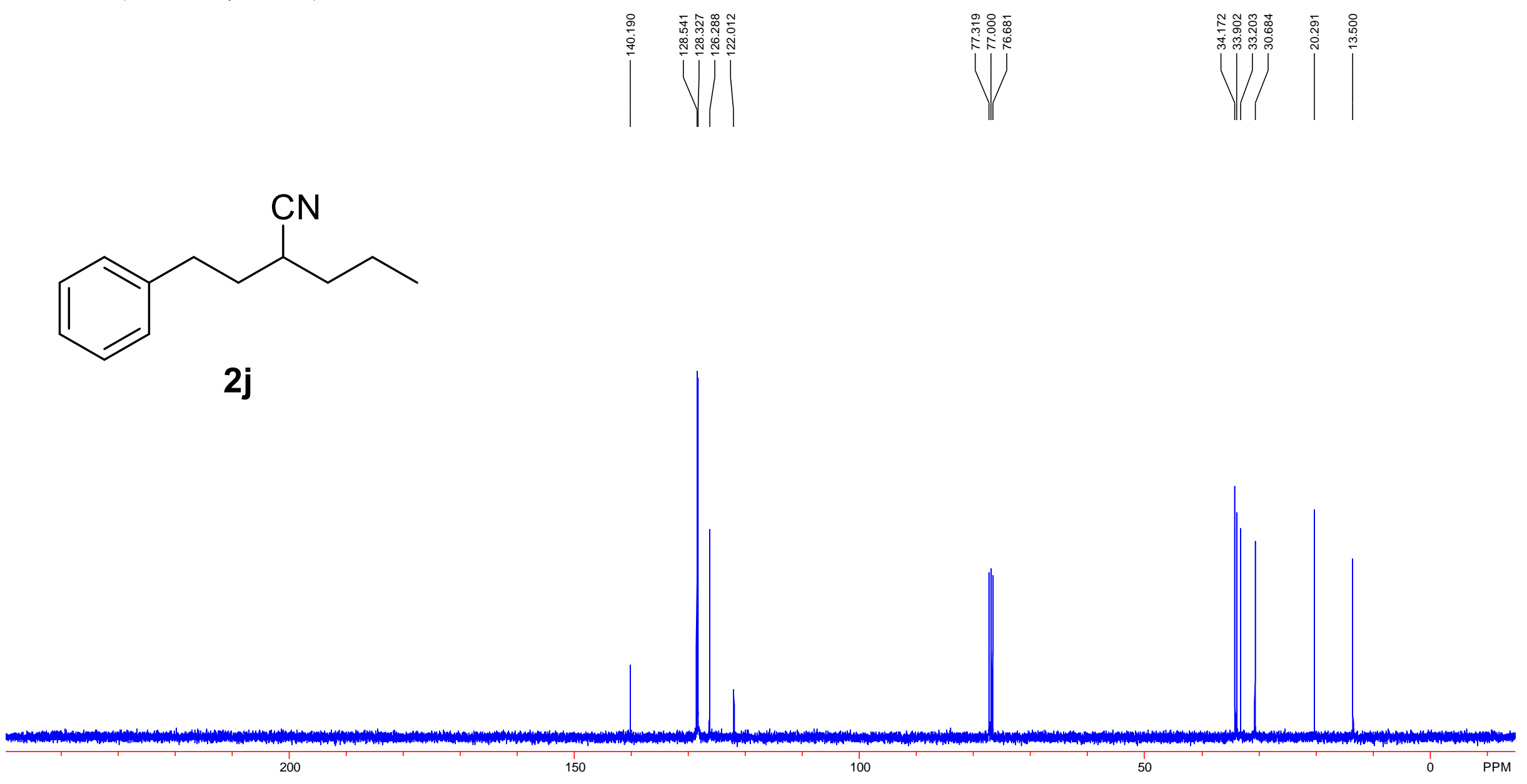
${ }^{1}$ H NMR (400 MHz, CDCl3)
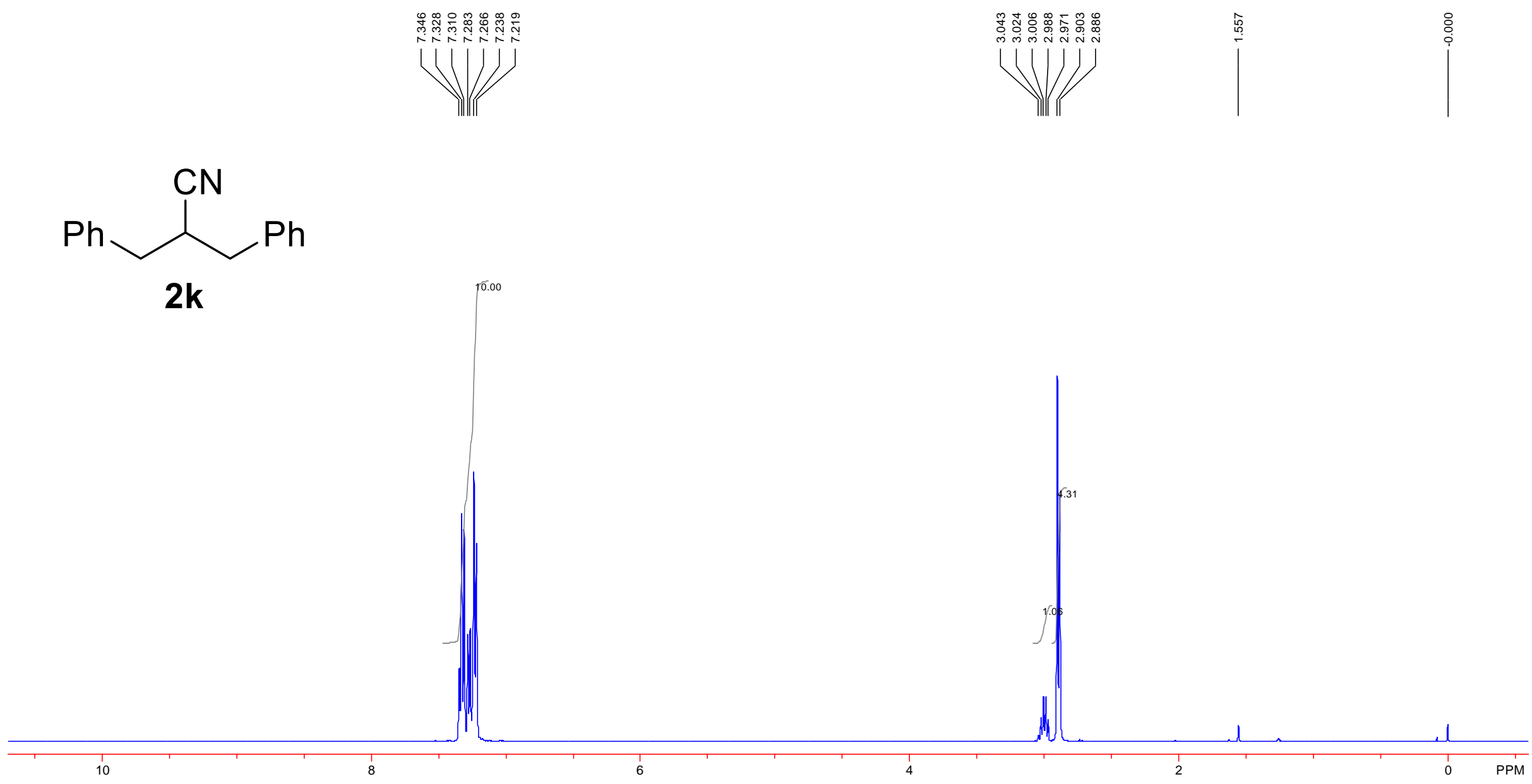
${ }^{13} \mathrm{C}$ NMR (100 MHz, CDCl3)
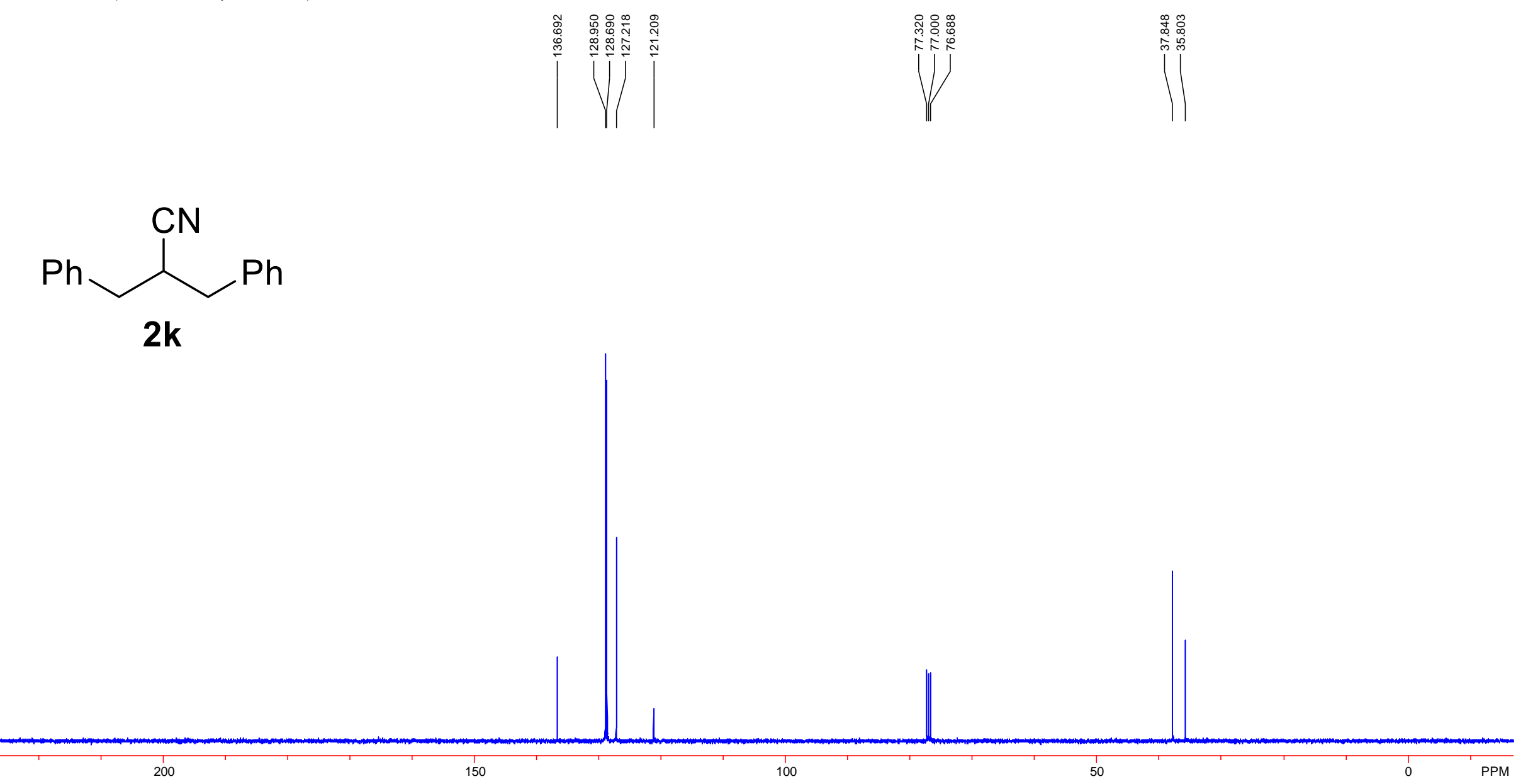
${ }^{1}$ H NMR (400 MHz, CDCl3)
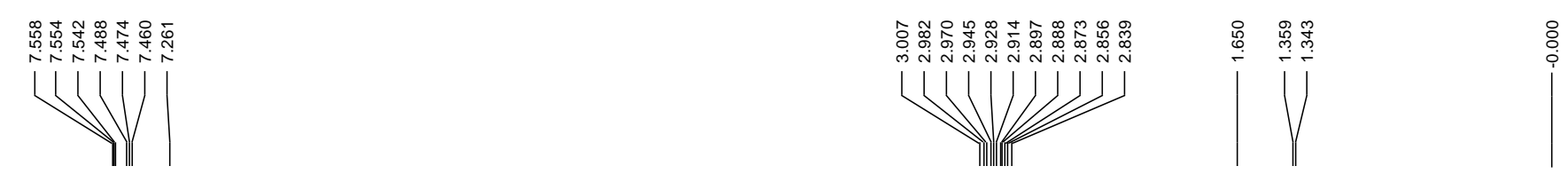<smiles>CC(C#N)Cc1cc[c]c(C(F)(F)F)c1</smiles>

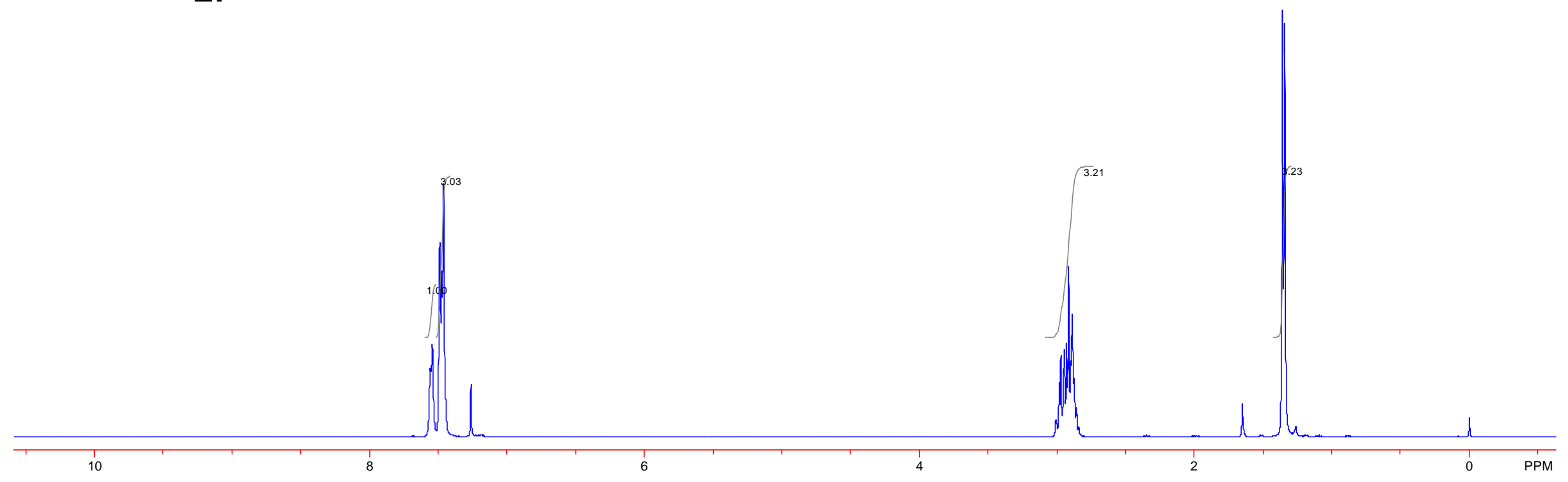


${ }^{13} \mathrm{C}$ NMR (100 MHz, CDCl3)

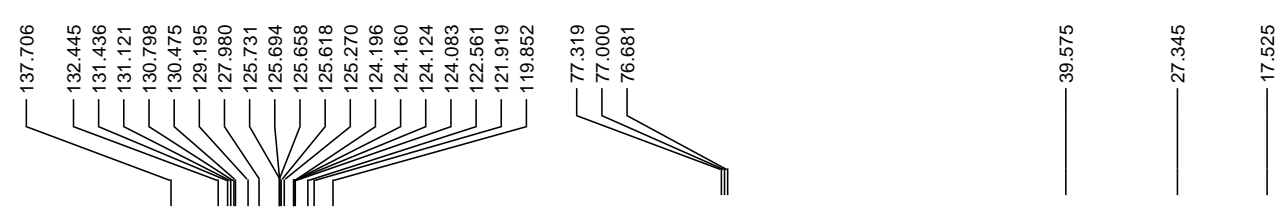<smiles>CC(C#N)Cc1cccc(C(F)(F)F)c1</smiles>

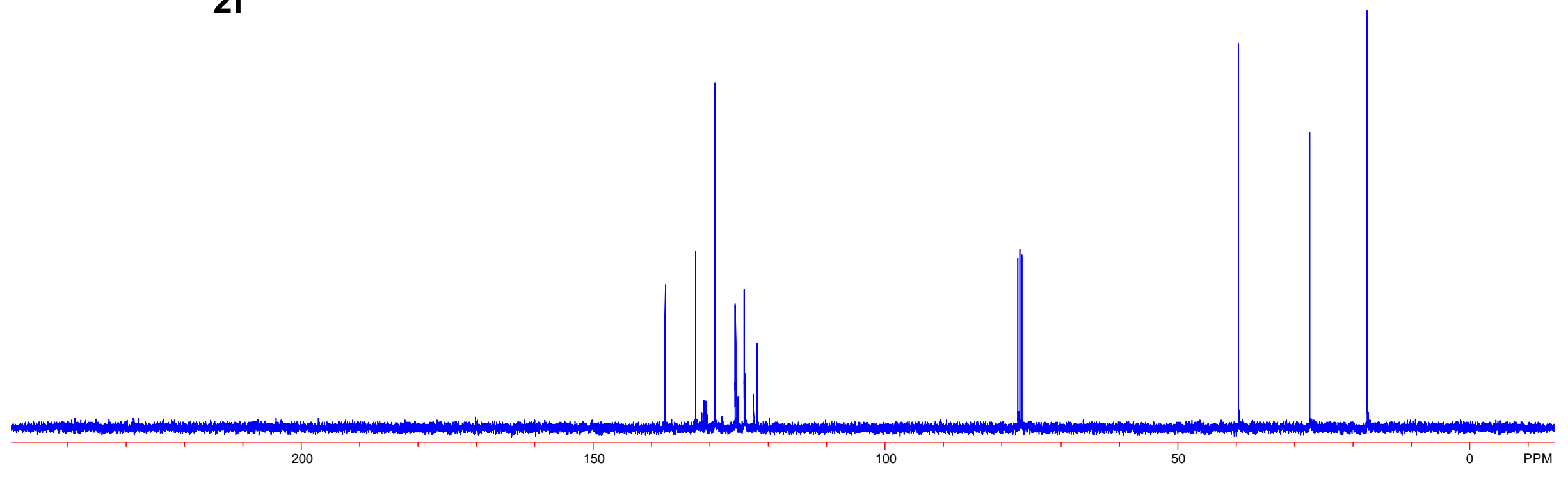


${ }^{1}$ H NMR (400 MHz, CDCl3)

$$
\text { 行 }
$$
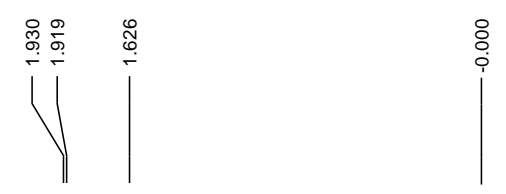<smiles>[3H]c1ccc(C=CC)cc1</smiles>

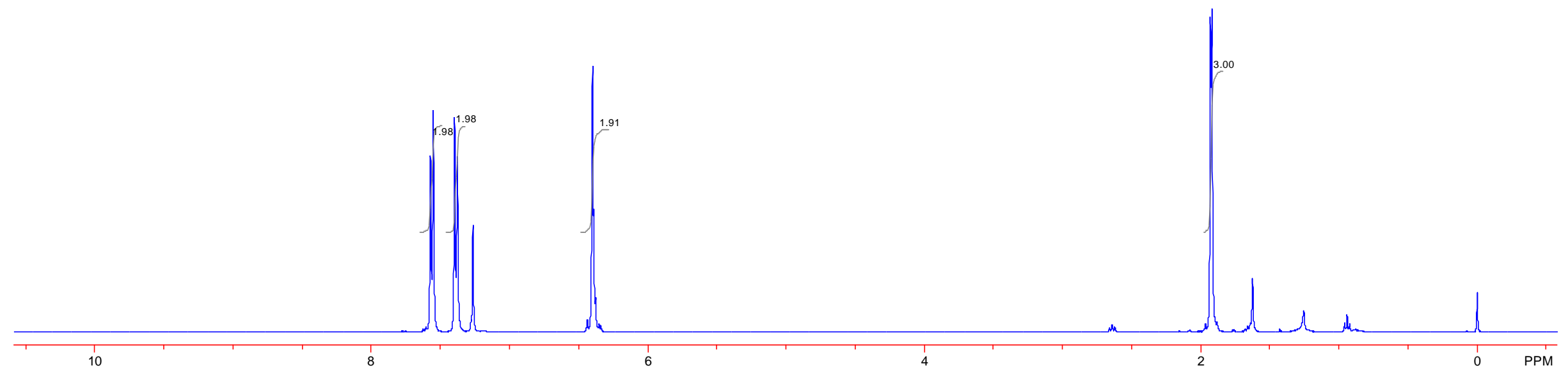


${ }^{13} \mathrm{C}$ NMR (100 MHz, CDCl3)
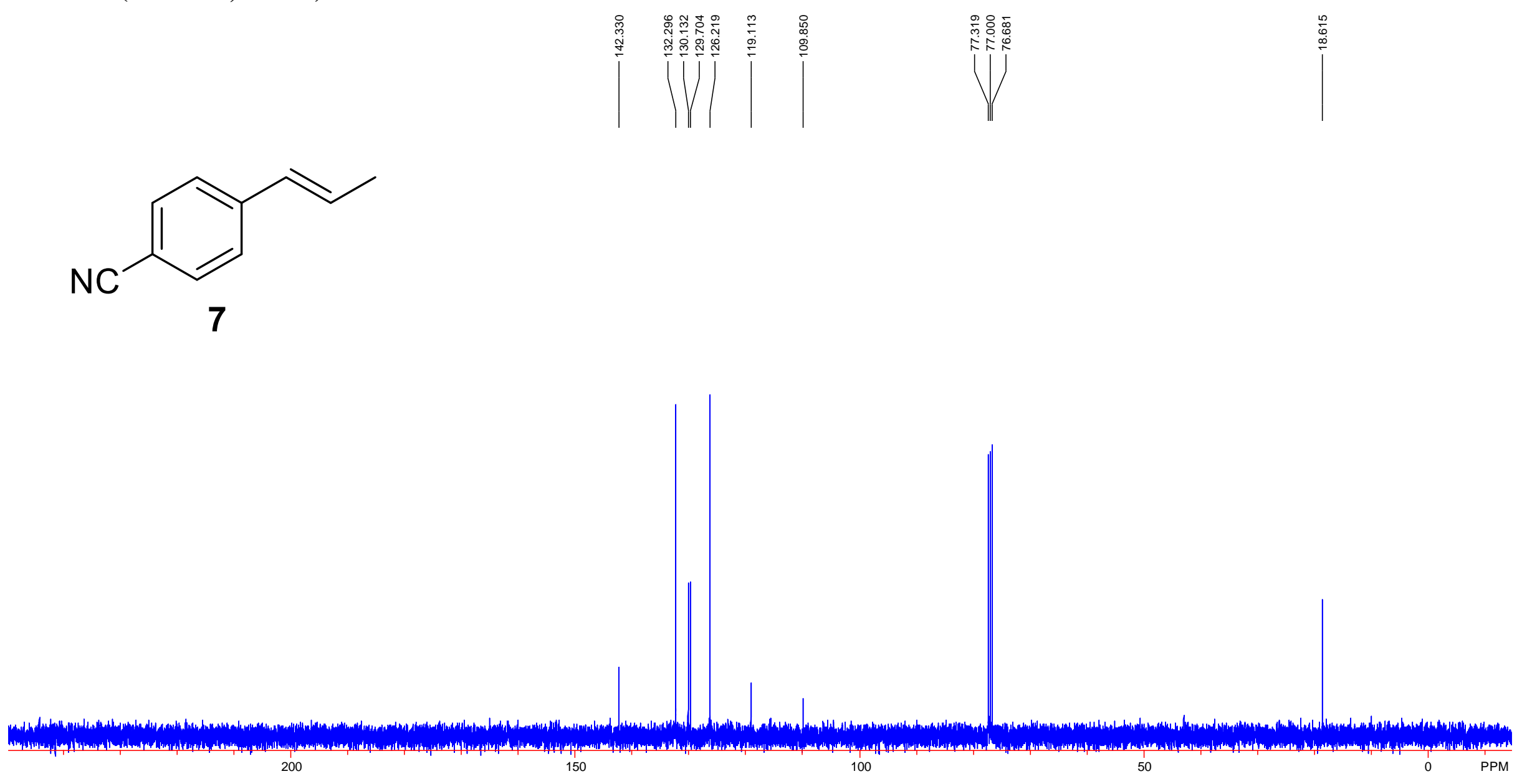
${ }^{1}$ H NMR (400 MHz, CDCl3)
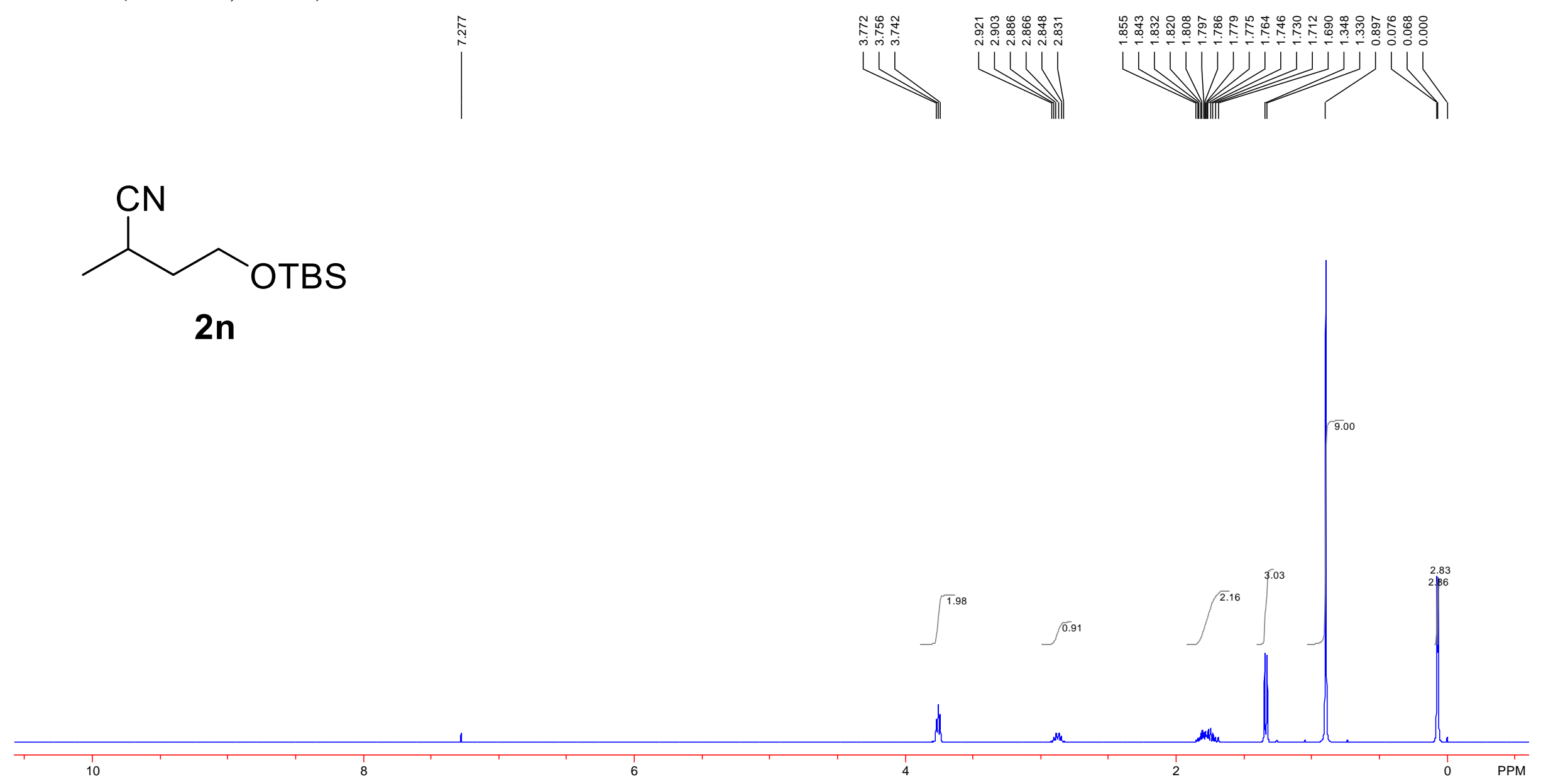
${ }^{13} \mathrm{C}$ NMR (100 MHz, CDCl3)
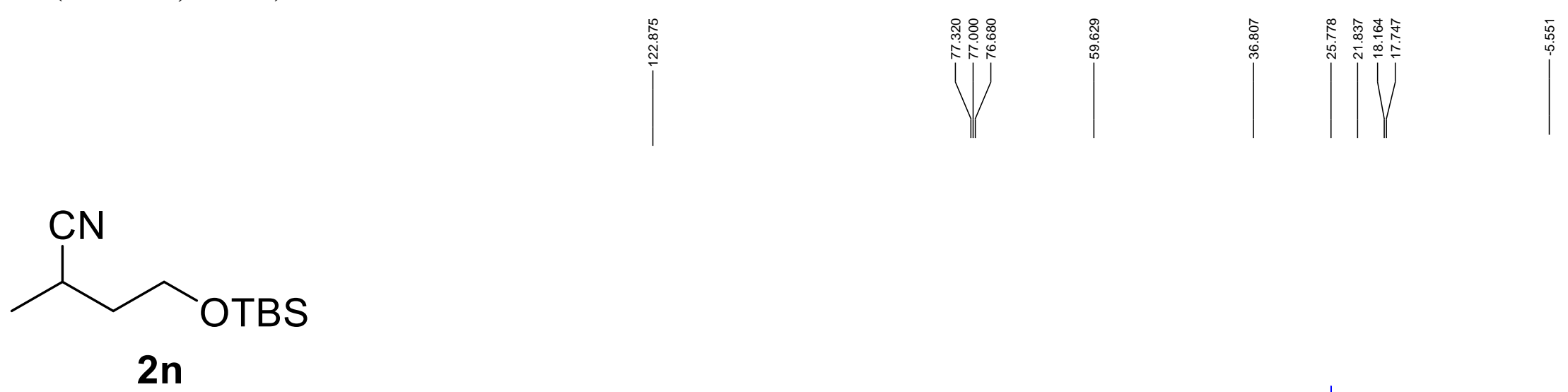
${ }^{1}$ H NMR (400 MHz, CDCl3)
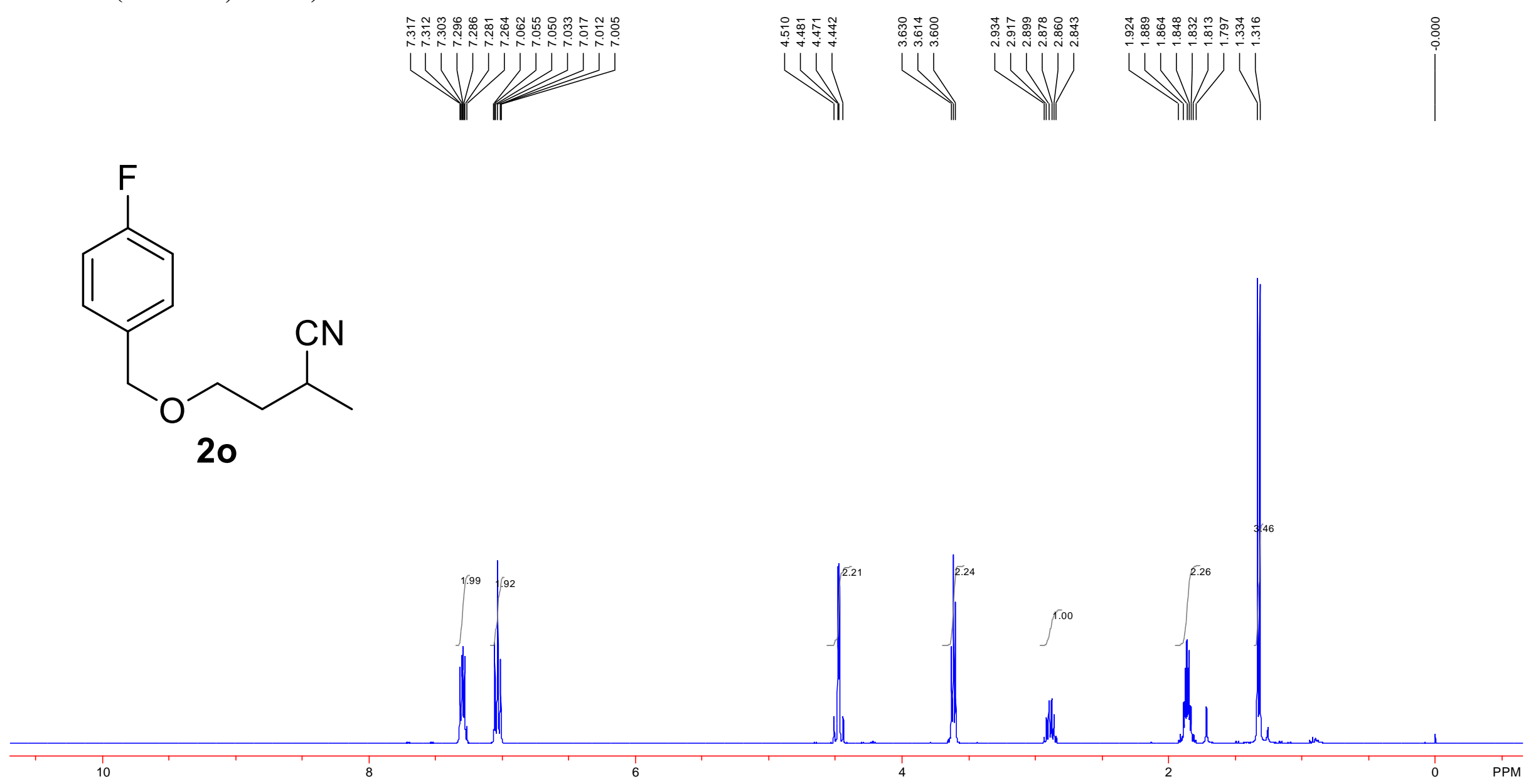
${ }^{13} \mathrm{C}$ NMR (100 MHz, CDCl3)
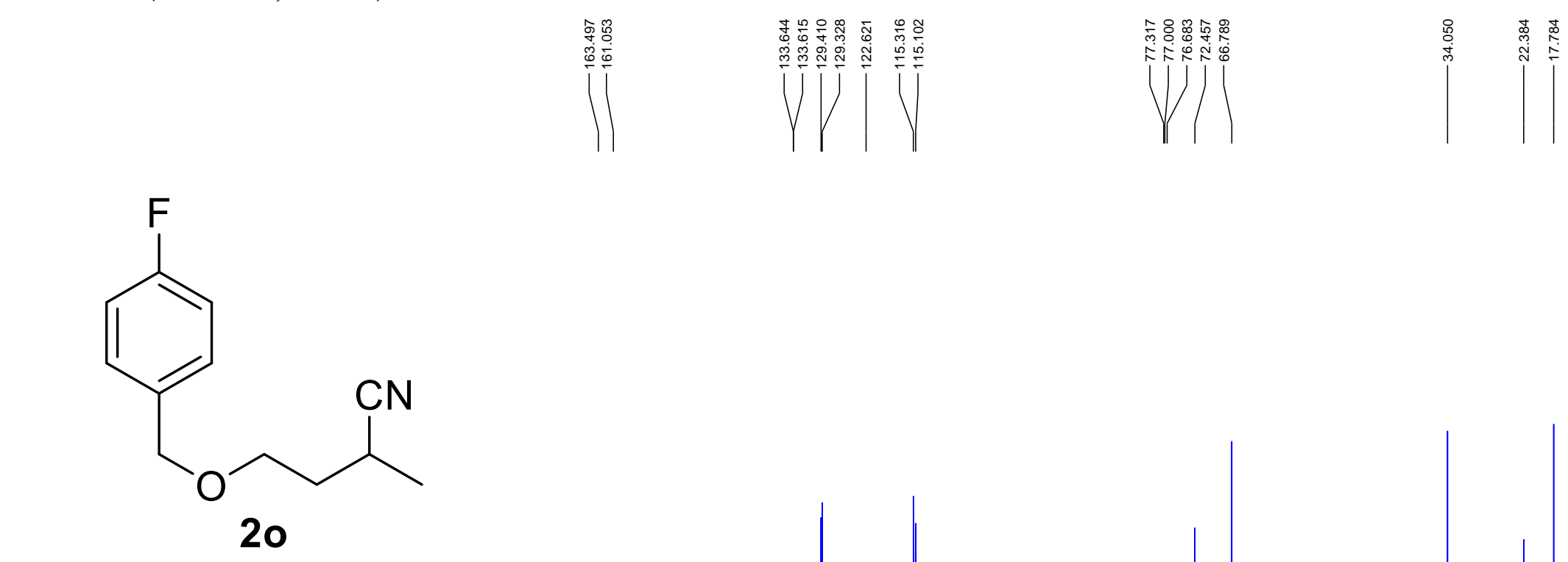
${ }^{1}$ H NMR (400 MHz, CDCl3)

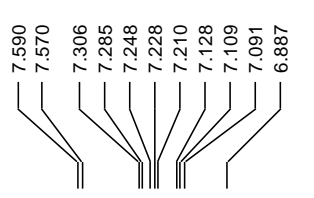

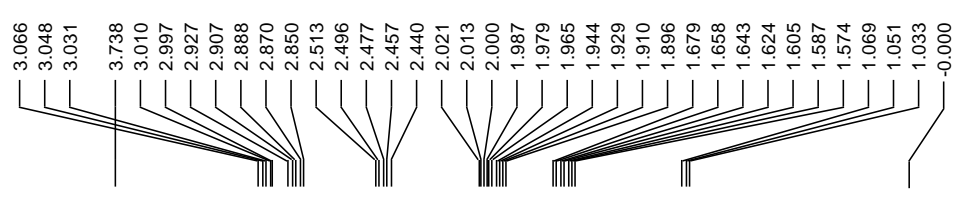<smiles>CCC(C#N)CCc1cn(C)c2ccccc12</smiles>

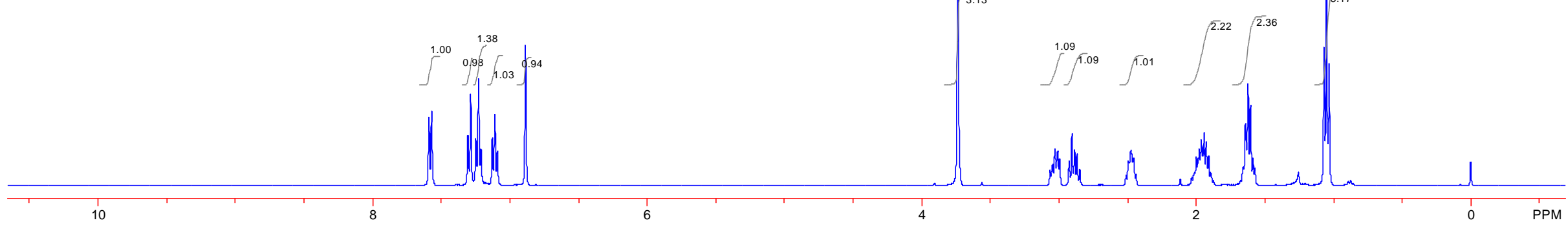


${ }^{13} \mathrm{C}$ NMR (100 MHz, CDCl3)
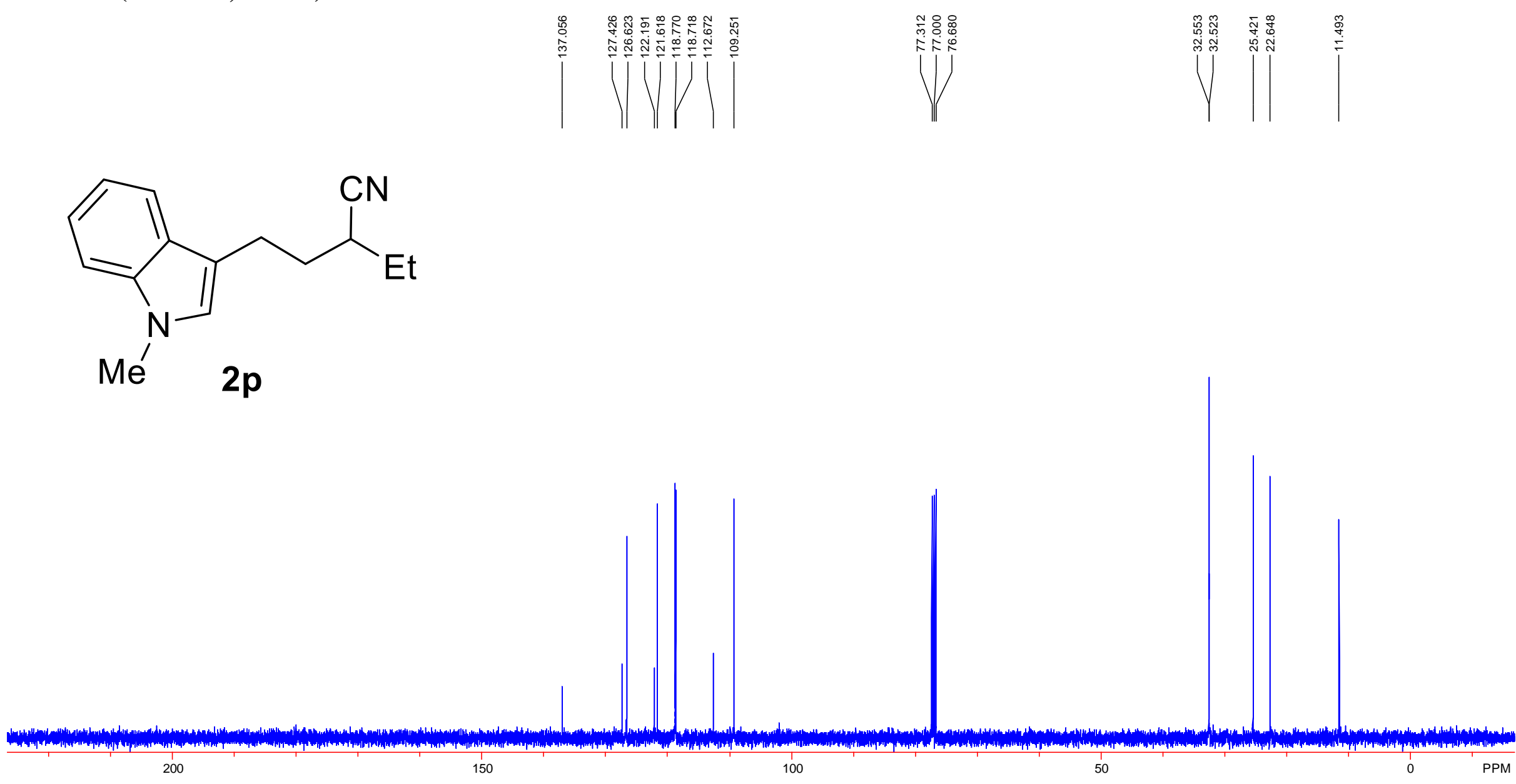
${ }^{1} \mathrm{H}$ NMR (400 MHz, CDCl3)
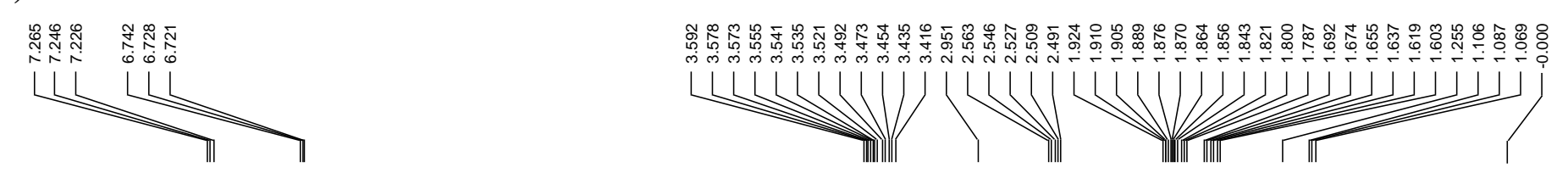<smiles>CCC(C#N)CCN(C)c1ccccc1</smiles>

2q

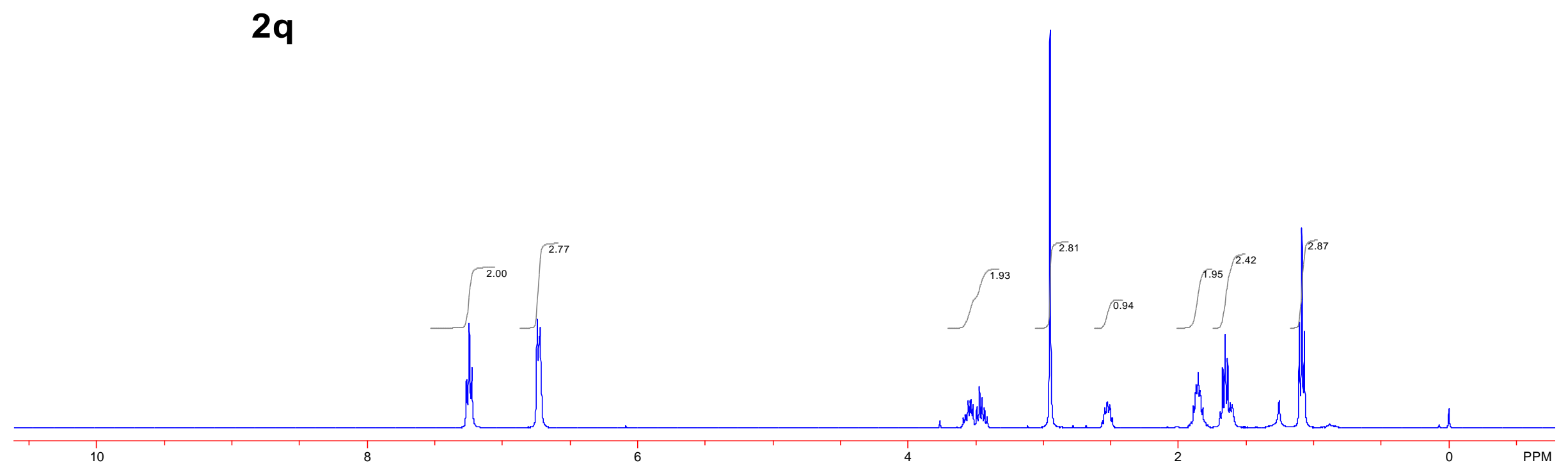


${ }^{13} \mathrm{C}$ NMR (100 MHz, CDCl3)

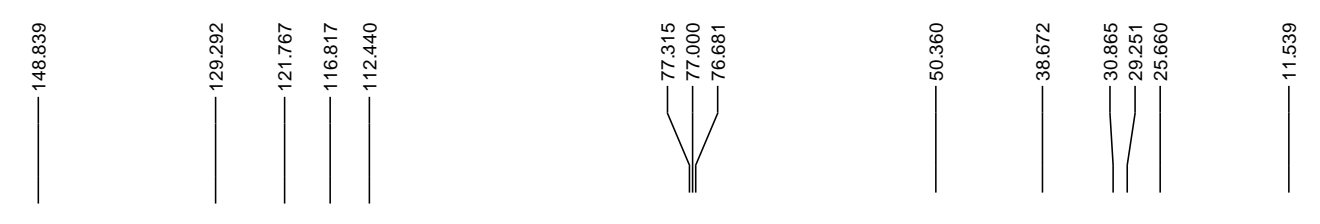<smiles>CCC(C#N)CCN(C)c1ccccc1</smiles>

$2 q$

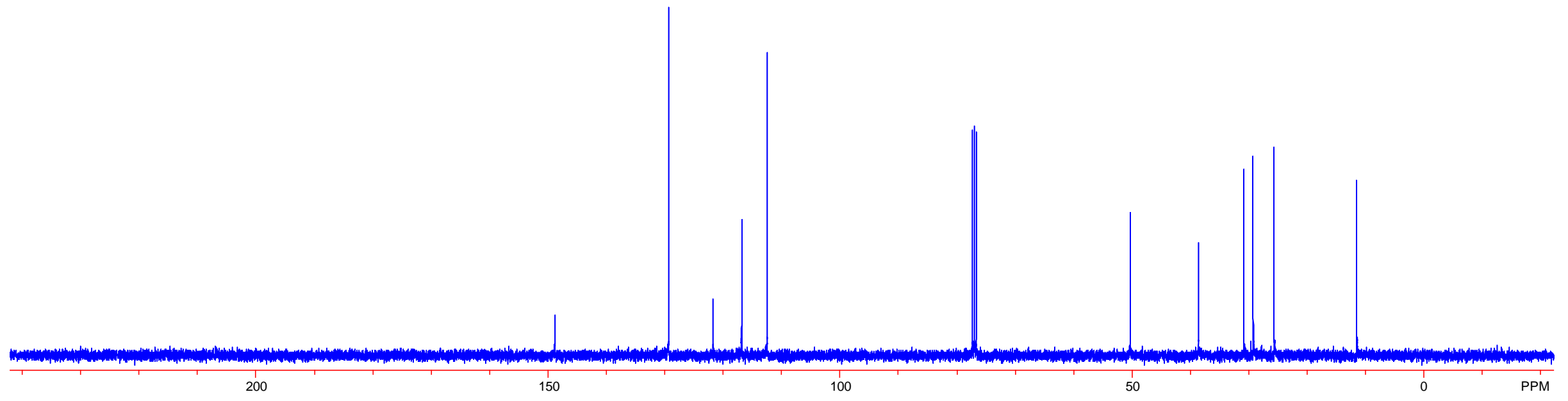


${ }^{1}$ H NMR (400 MHz, CDCl3)

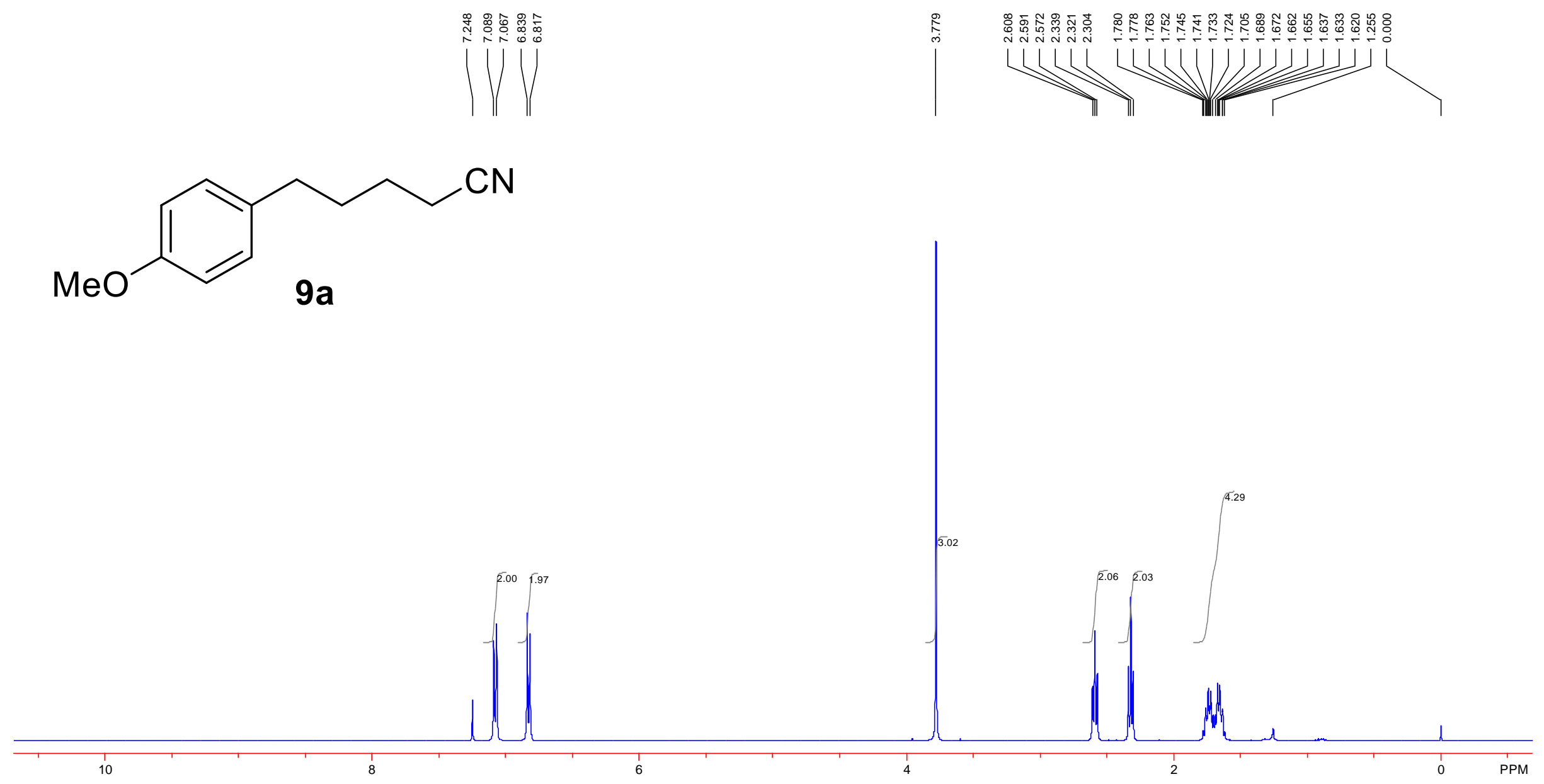


${ }^{13} \mathrm{C}$ NMR (100 MHz, CDCl3)
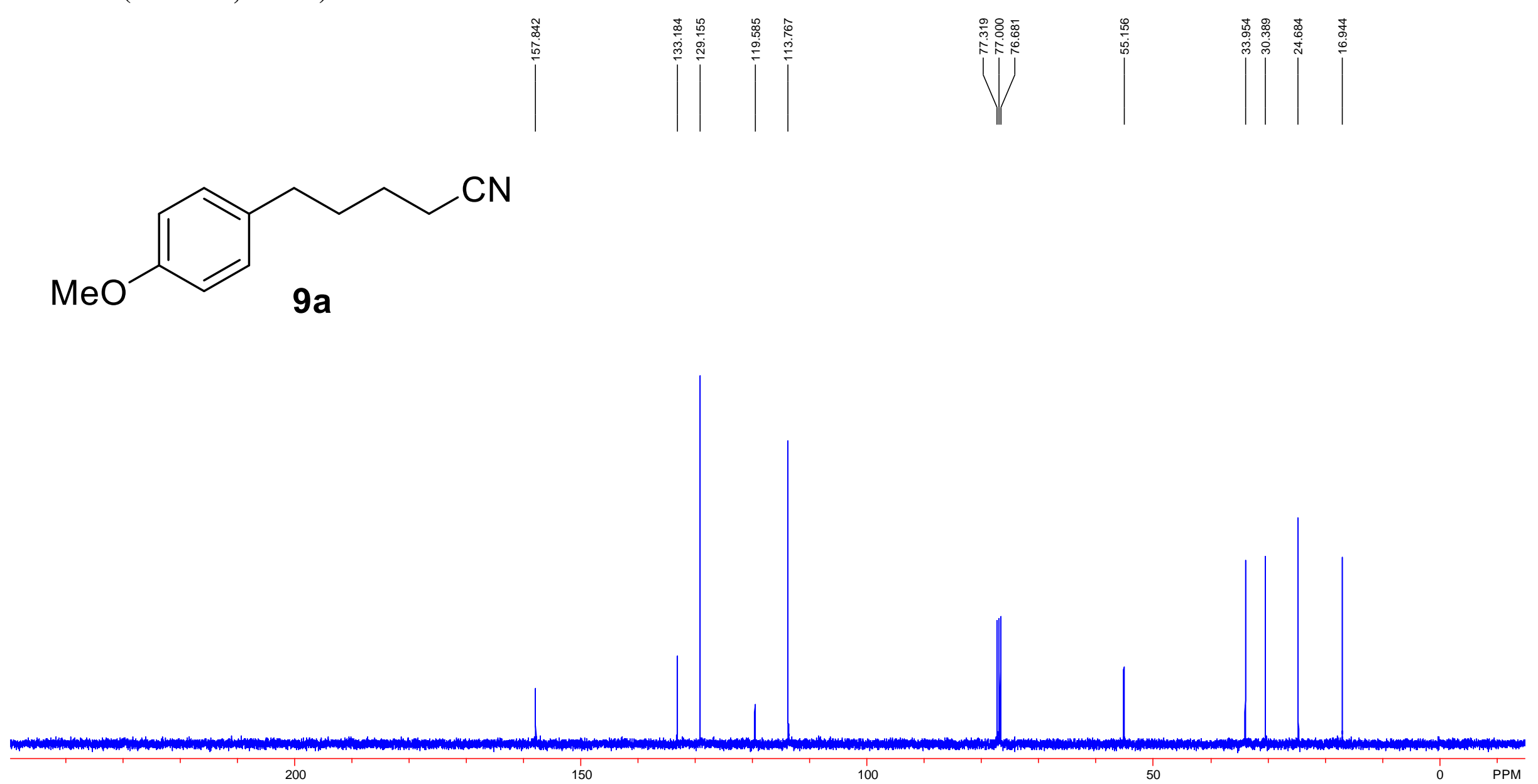
${ }^{1}$ H NMR (400 MHz, CDCl3)

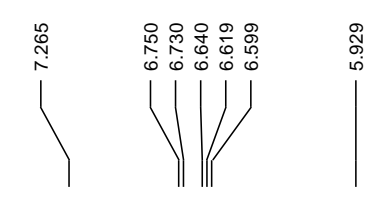

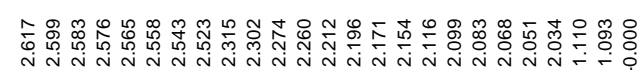
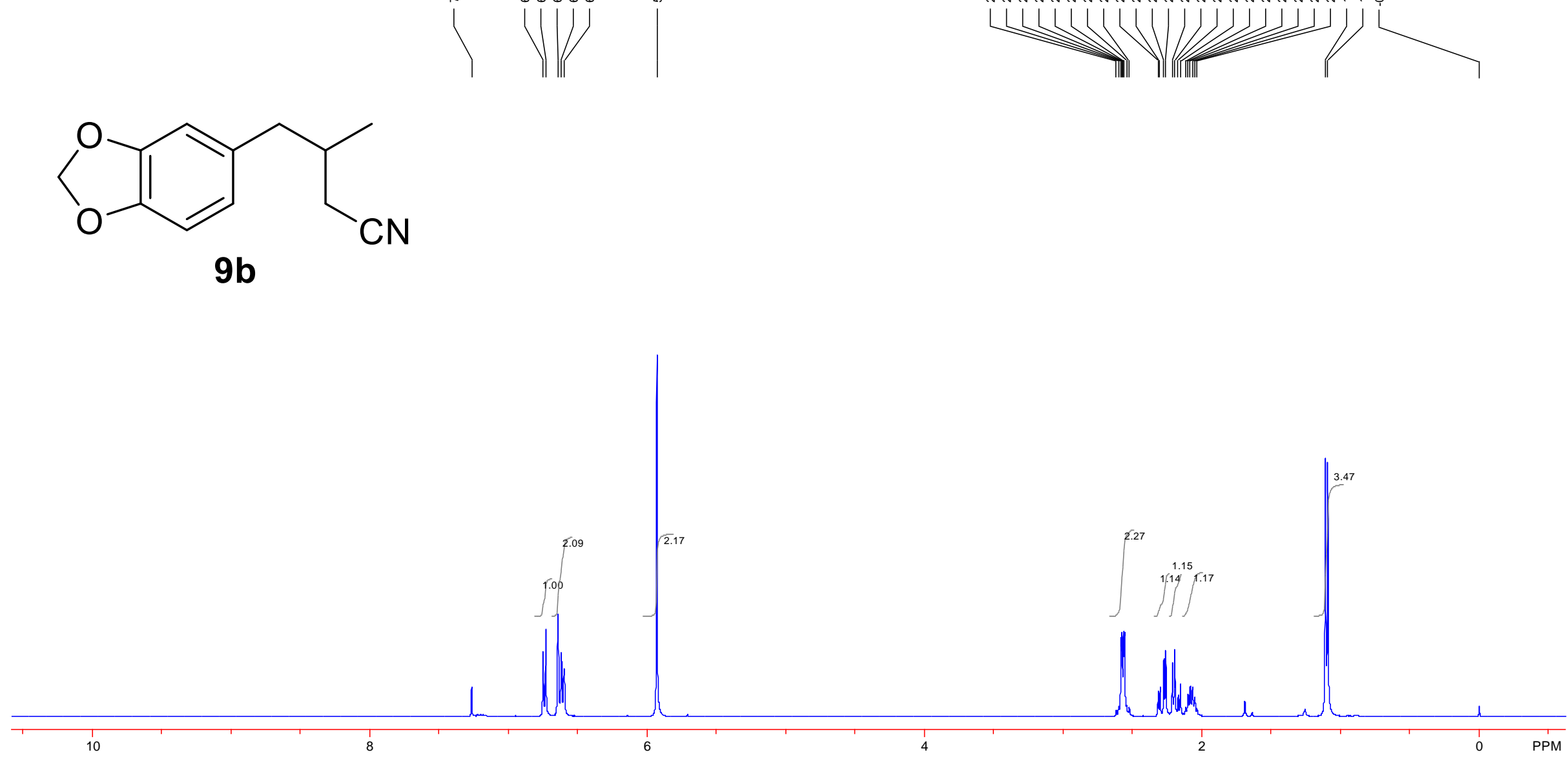
${ }^{13} \mathrm{C}$ NMR (100 MHz, CDCl3)

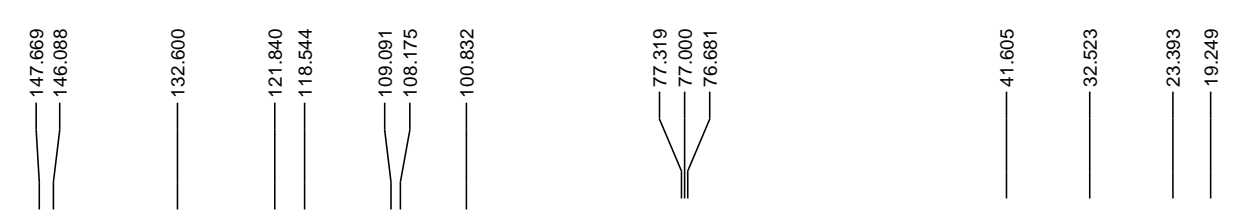<smiles>CC(CC#N)Cc1ccc2c(c1)OCO2</smiles>

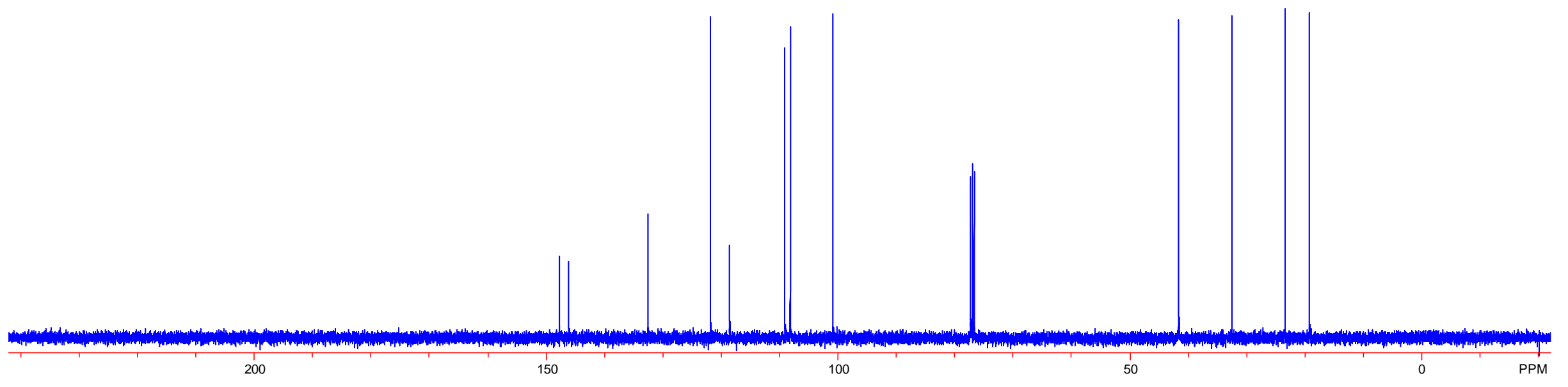


${ }^{1}$ H NMR (400 MHz, CDCl3)

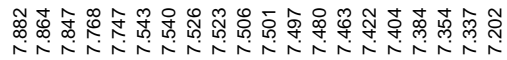

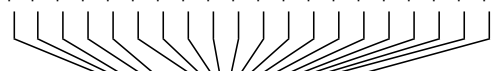

I 1 -

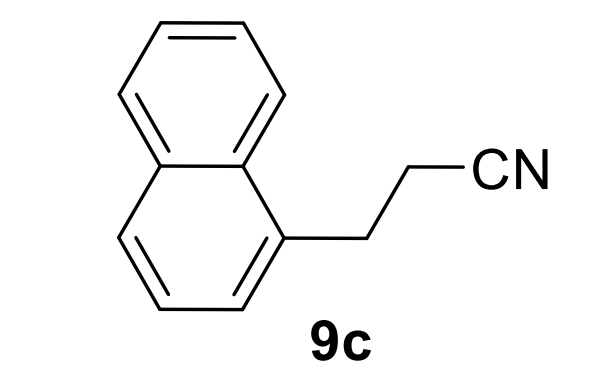

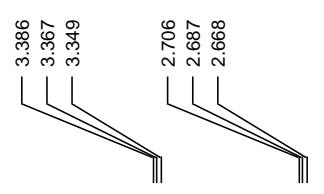

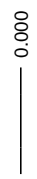

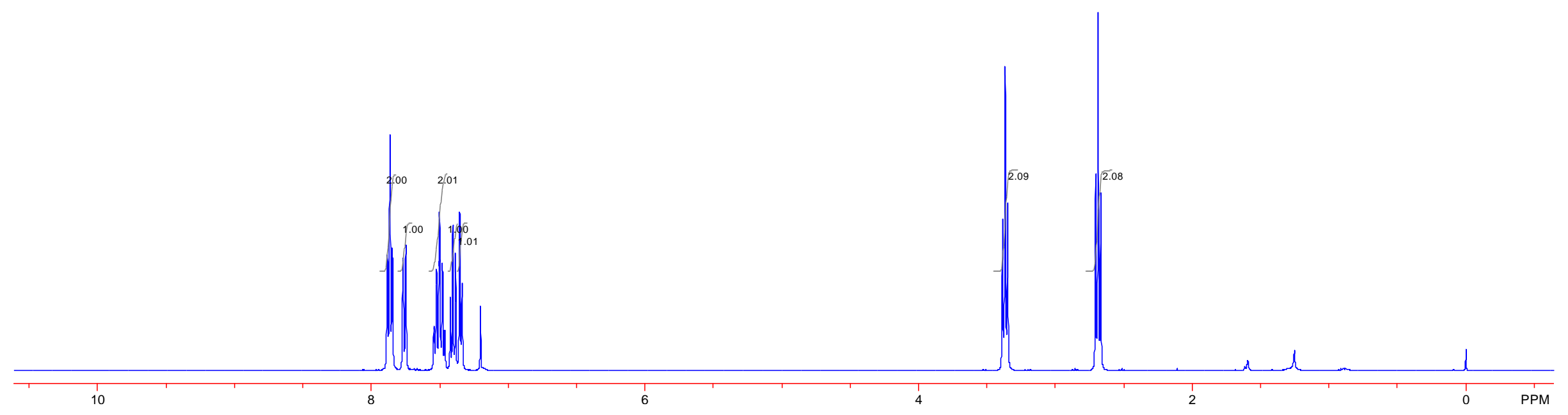


${ }^{13} \mathrm{C}$ NMR (100 MHz, CDCl3)
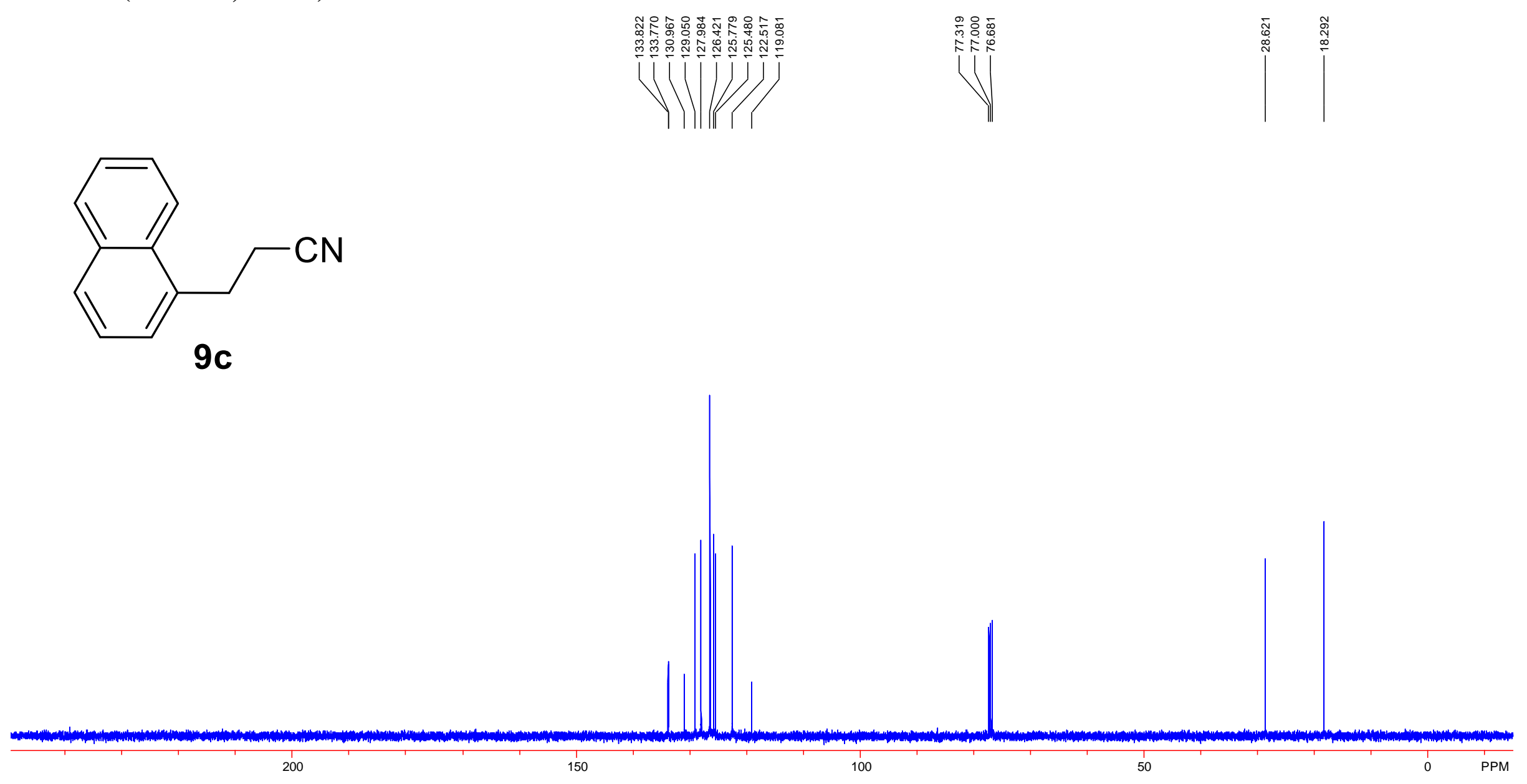
${ }^{1} \mathrm{H}$ NMR (400 MHz, CDCl3)
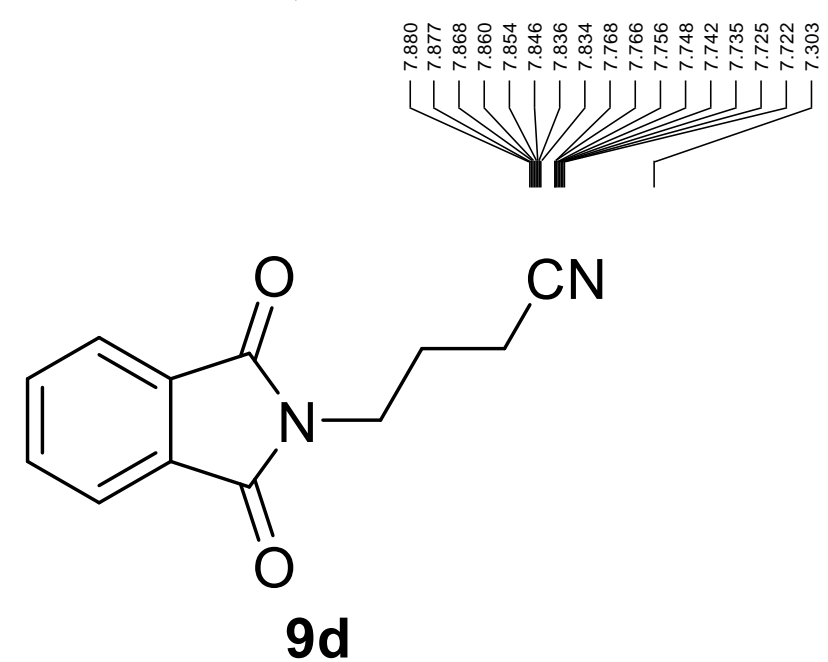
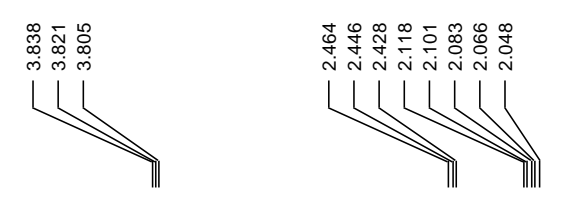

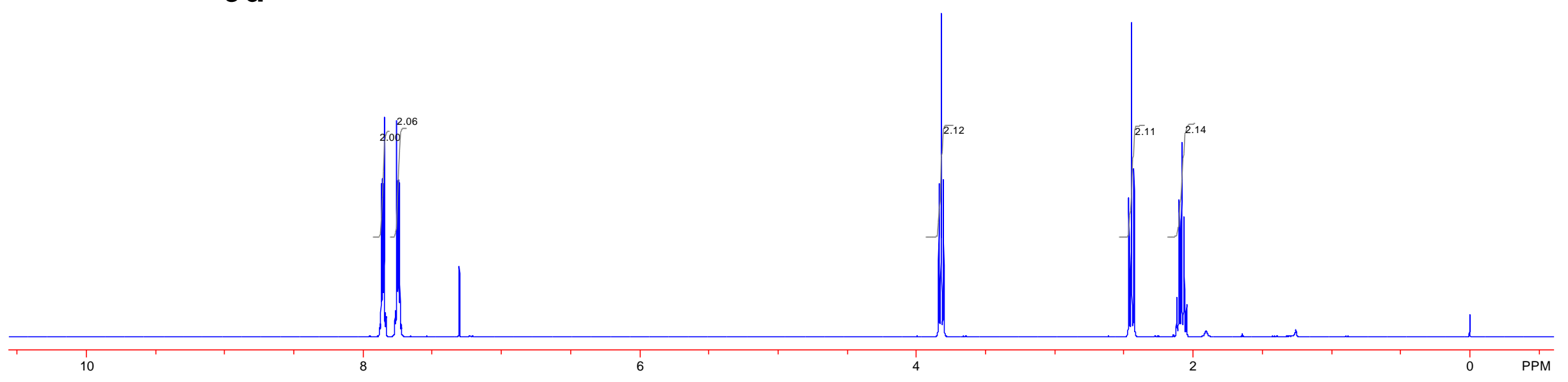


${ }^{13} \mathrm{C}$ NMR (100 MHz, CDCl3)

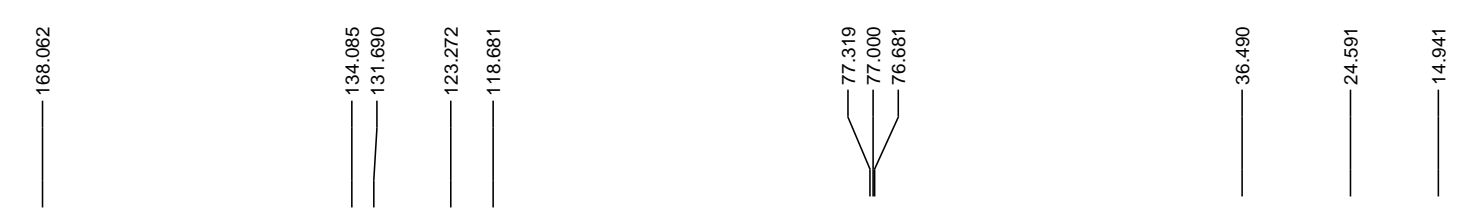<smiles>N#CCCCN1C(=O)c2ccccc2C1=O</smiles>

9d 
${ }^{1}$ H NMR (400 MHz, CDCl3)
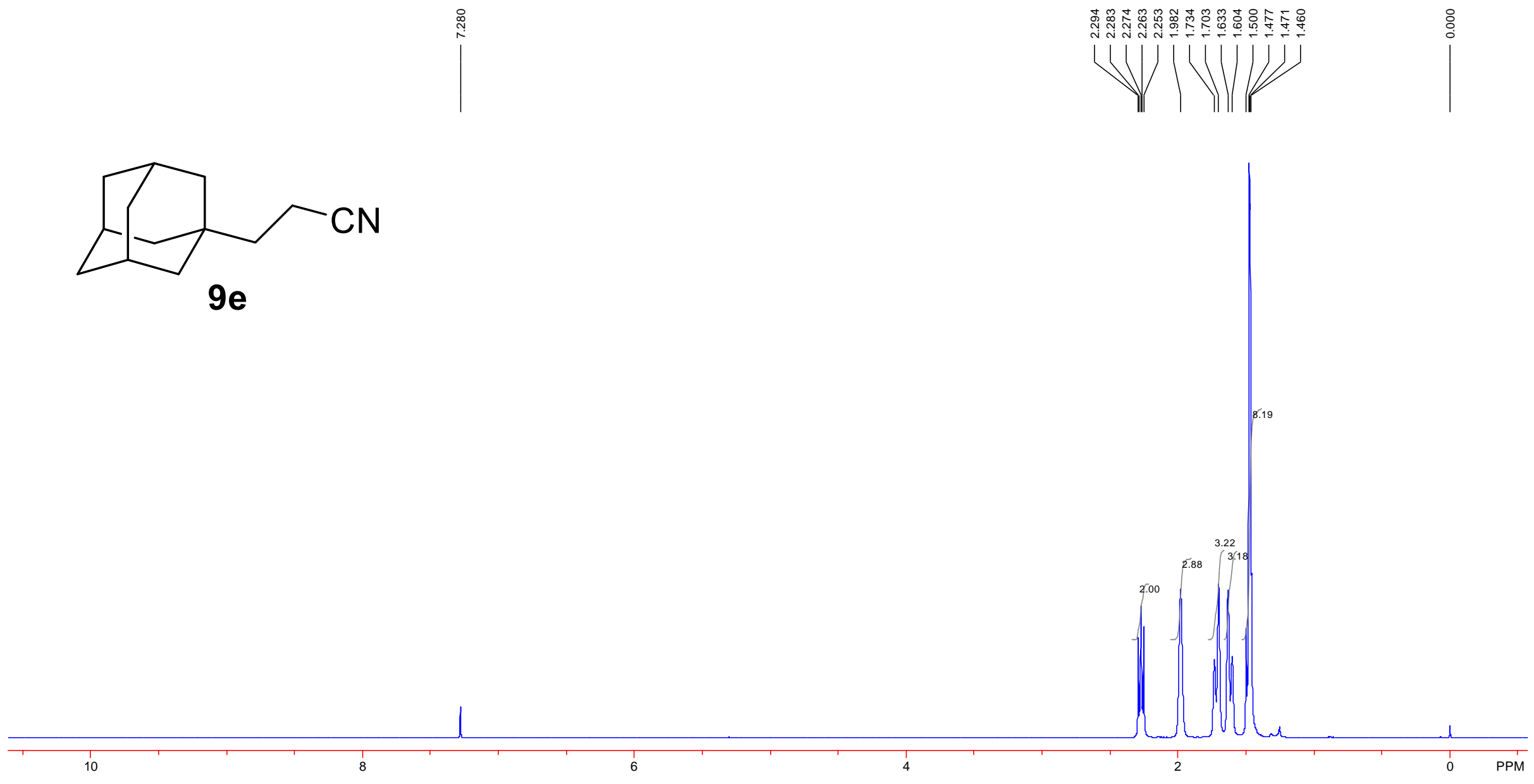
${ }^{13} \mathrm{C}$ NMR (100 MHz, CDCl3)
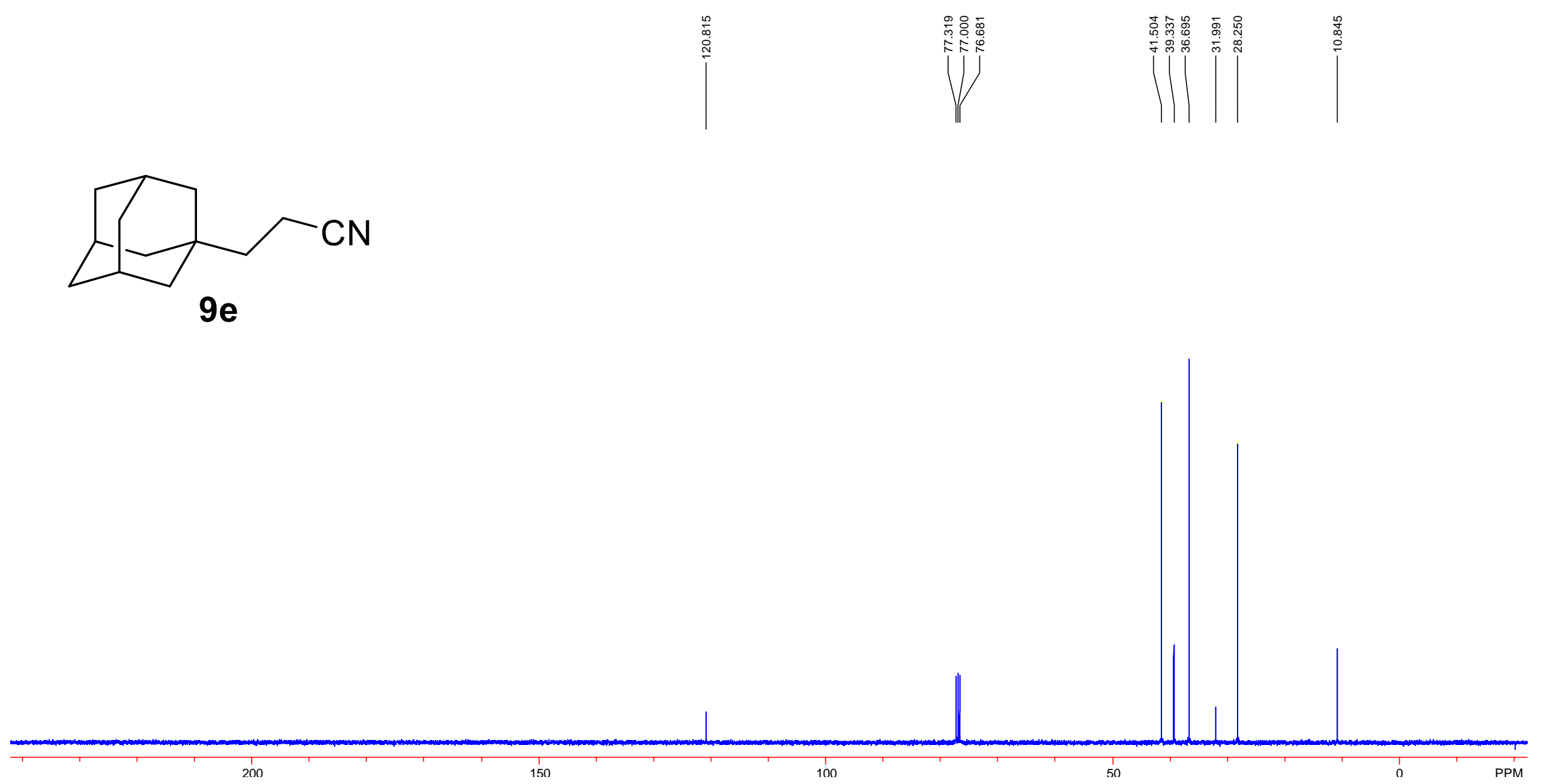
${ }^{1} \mathrm{H}$ NMR (400 MHz, CDCl3)
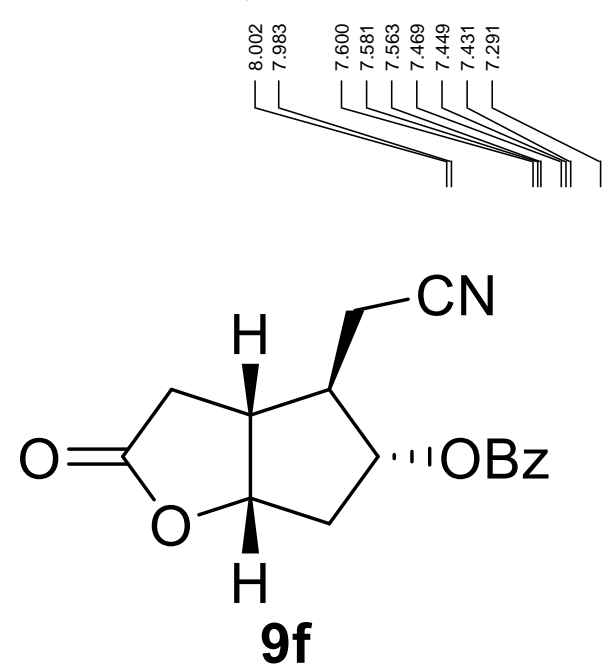

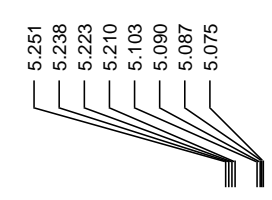

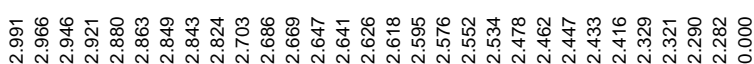

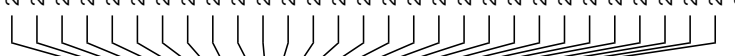
$(1)$

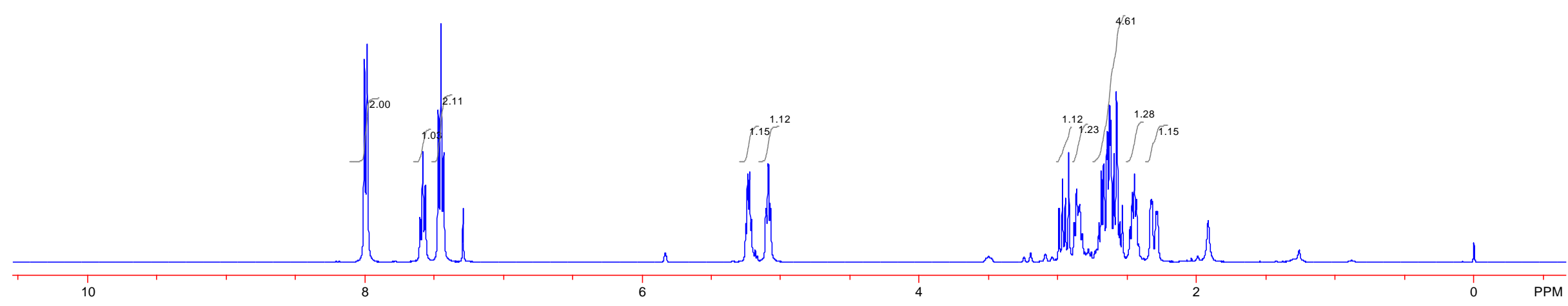


${ }^{13} \mathrm{C}$ NMR (100 MHz, CDCl3)
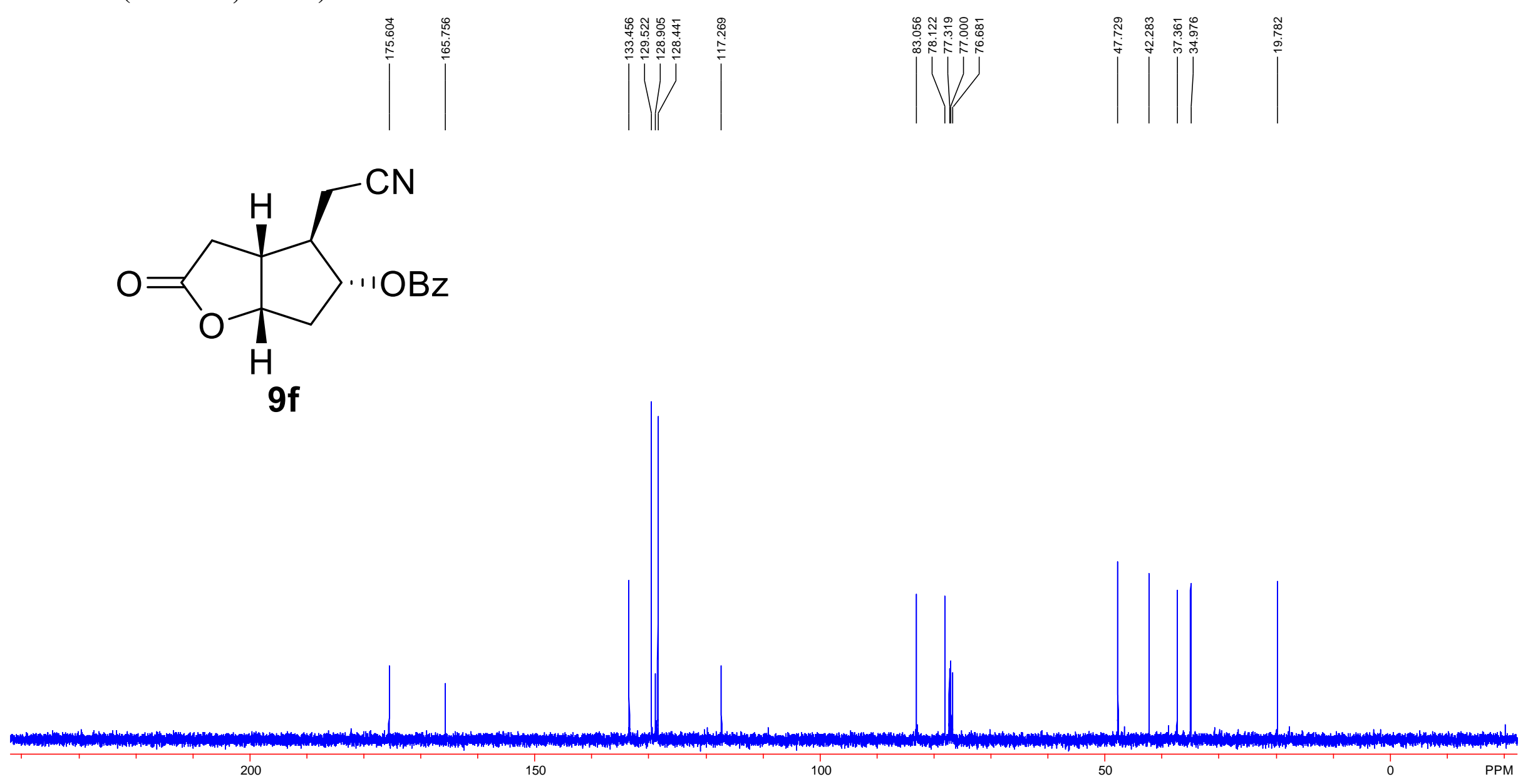
${ }^{1}$ H NMR (400 MHz, CDCl3)
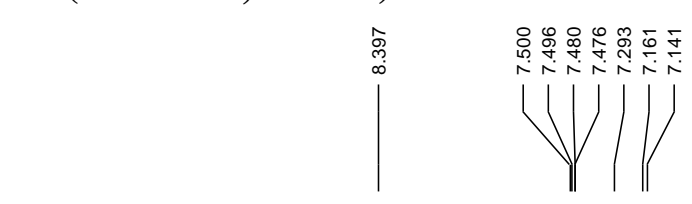

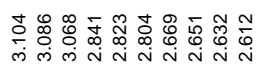

UVWU

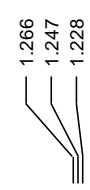<smiles>CCc1ccc(CCC#N)nc1</smiles>

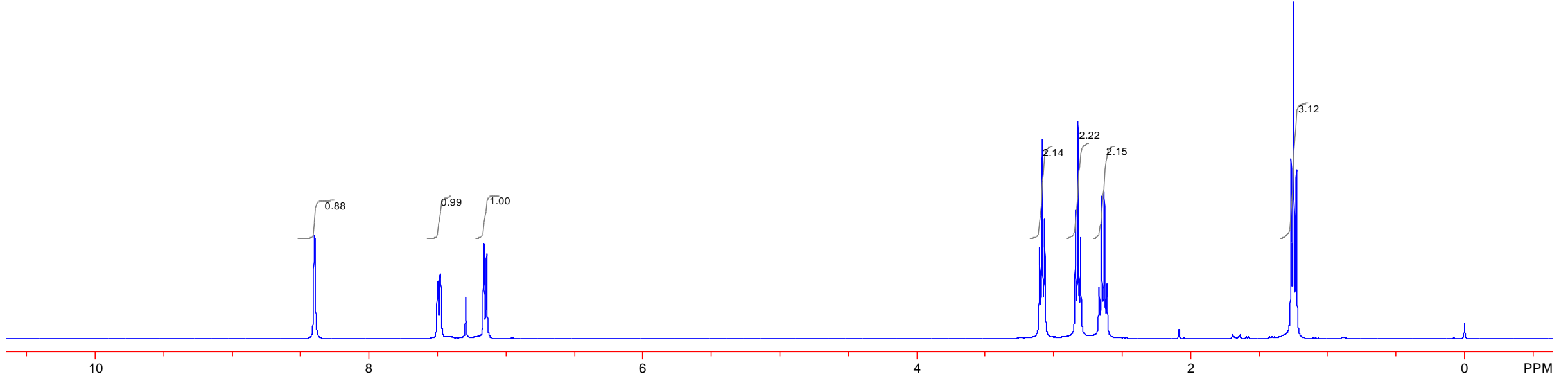


${ }^{13} \mathrm{C}$ NMR (100 MHz, CDCl3)
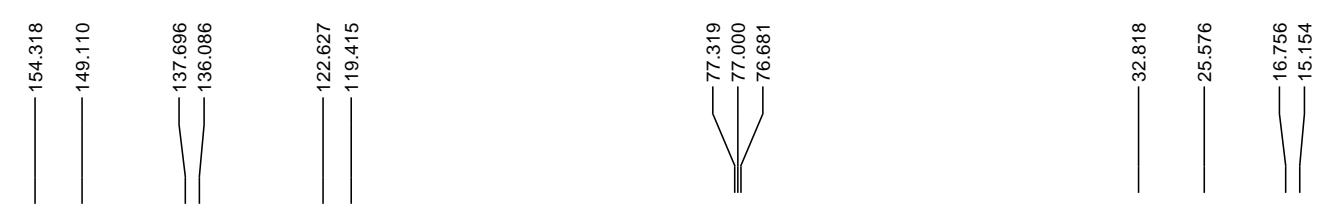<smiles>CCc1ccc(CCC#N)nc1</smiles>

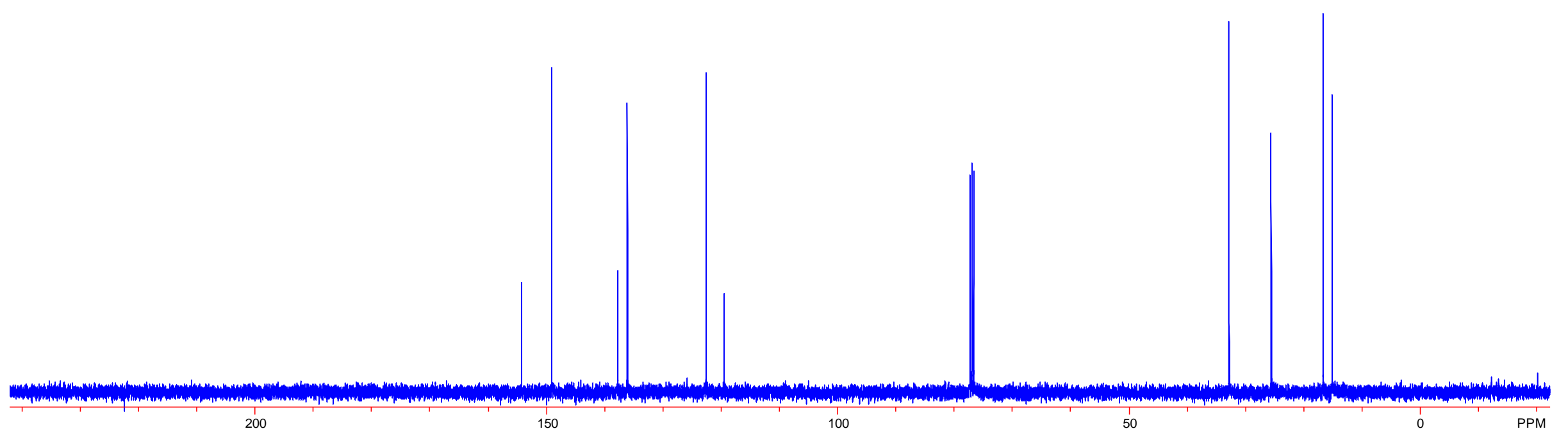


${ }^{1}$ H NMR (400 MHz, CDCl3)
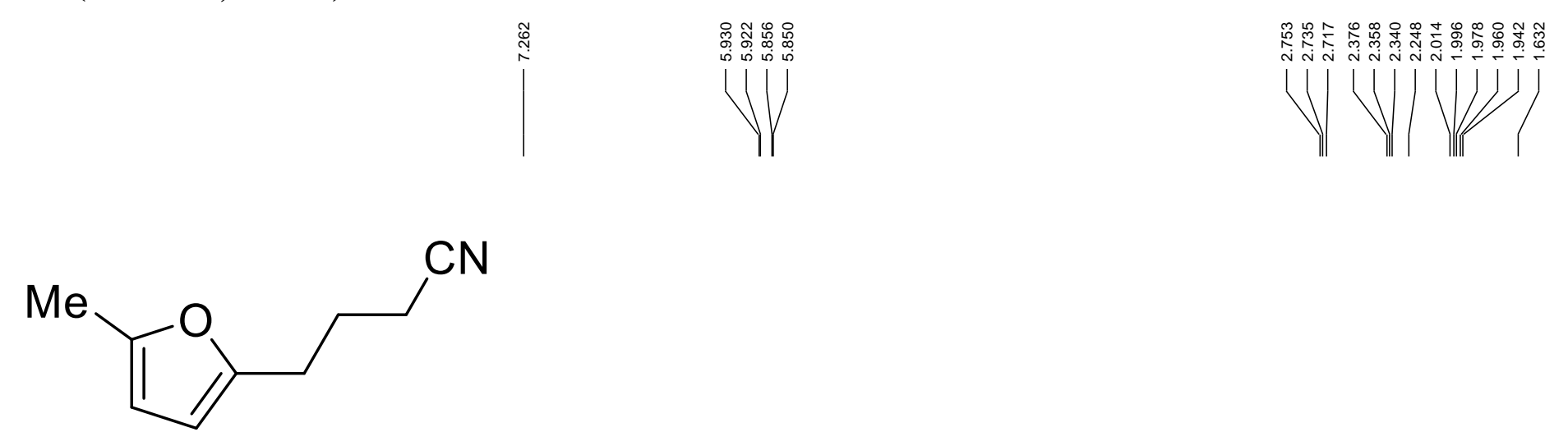

9h

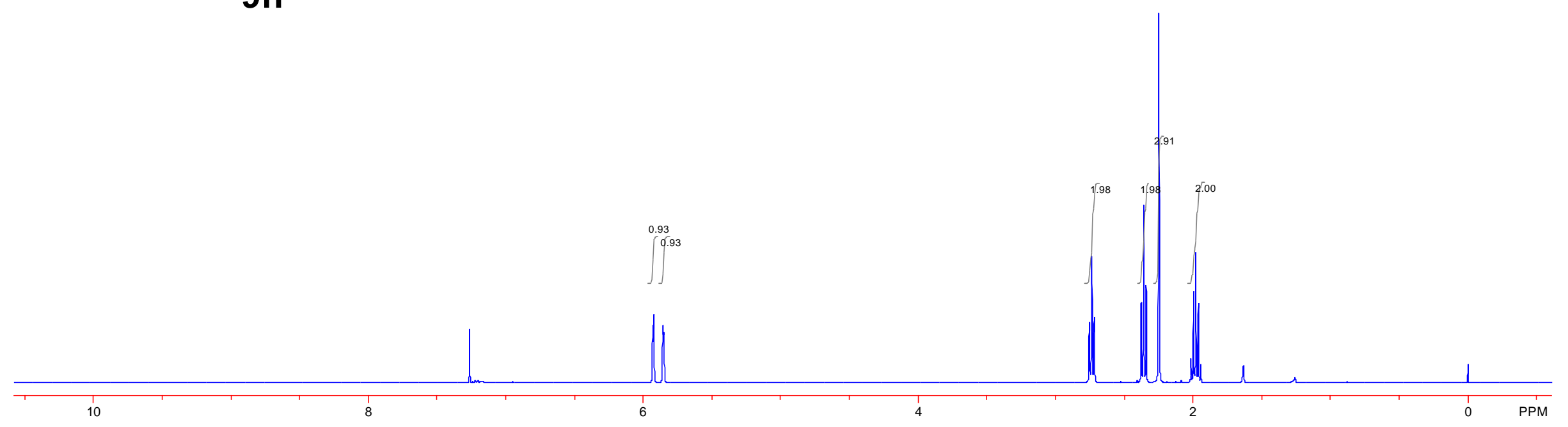


${ }^{13} \mathrm{C}$ NMR (100 MHz, CDCl3)
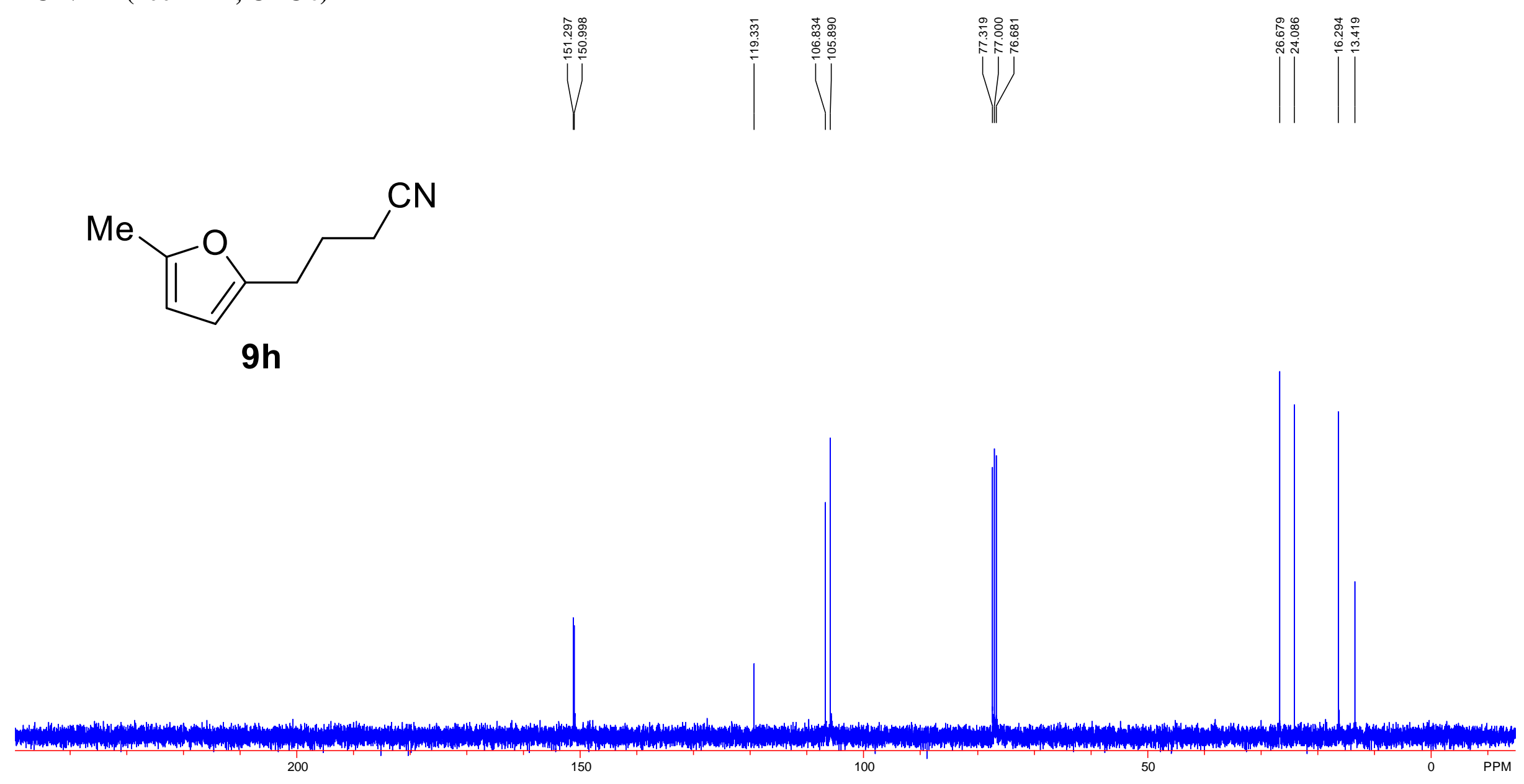
${ }^{1}$ H NMR (400 MHz, CDCl3)

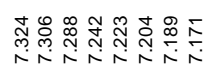
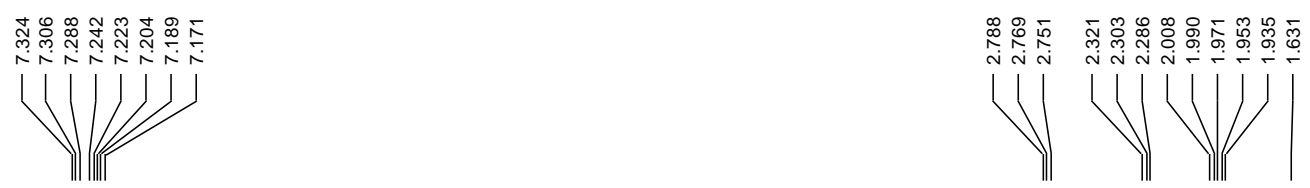<smiles>N#CCCCc1ccccc1</smiles>

$9 \mathrm{i}$
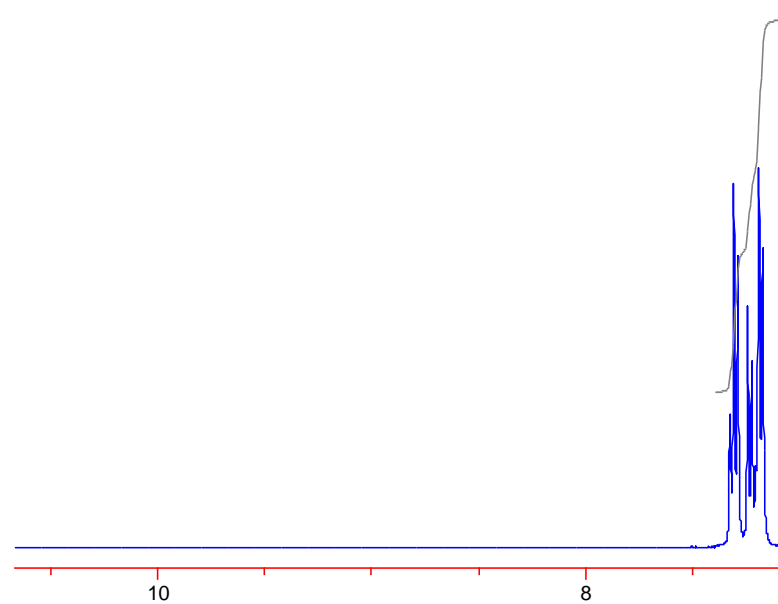
${ }^{13} \mathrm{C}$ NMR (100 MHz, CDCl3)
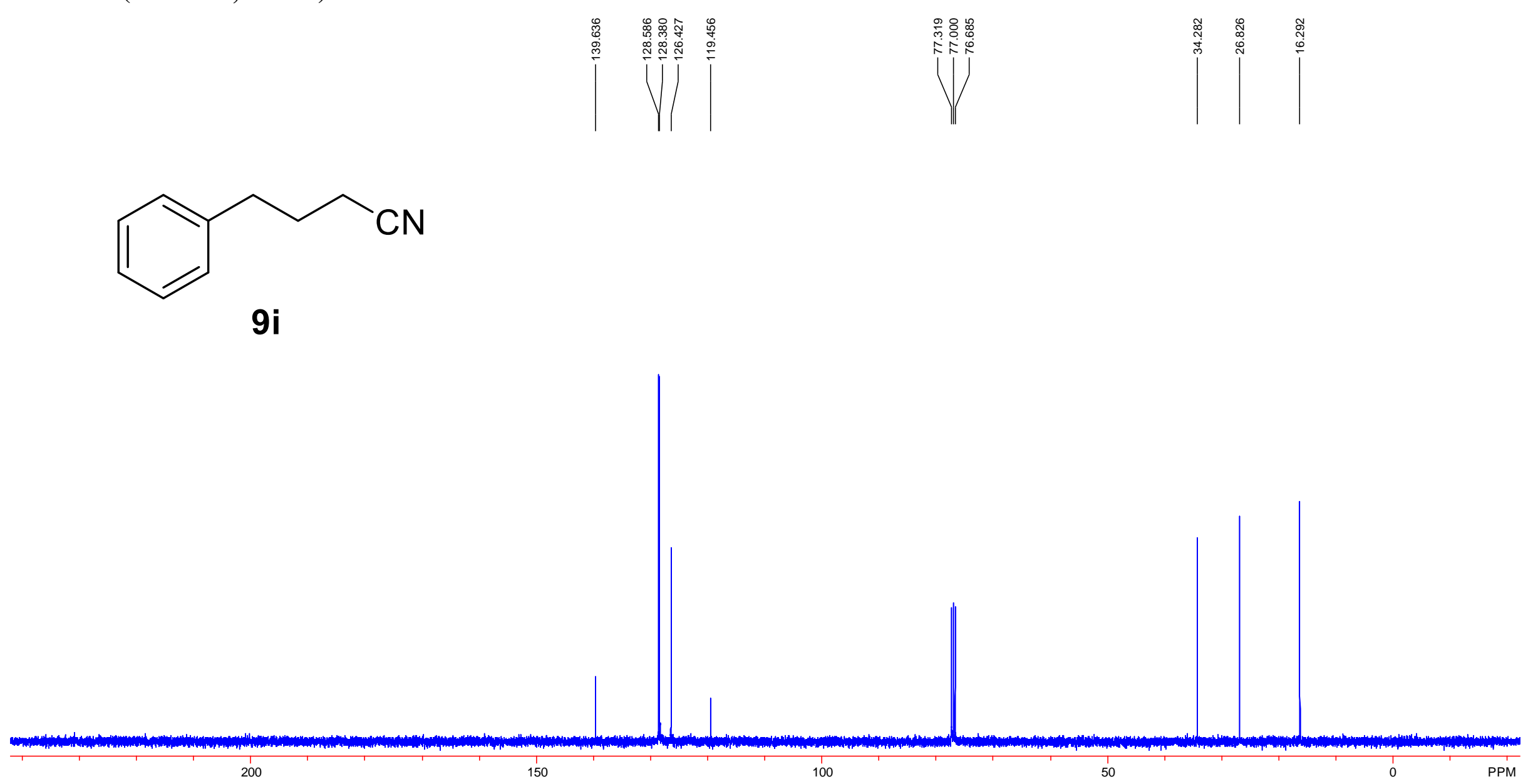
${ }^{1}$ H NMR (400 MHz, CDCl3)
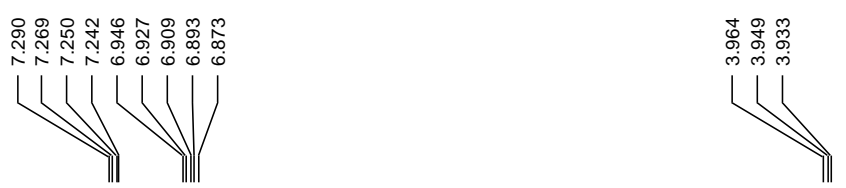

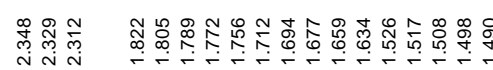

응

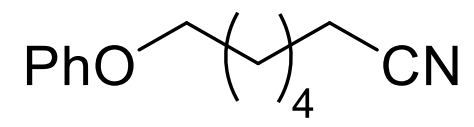

9j

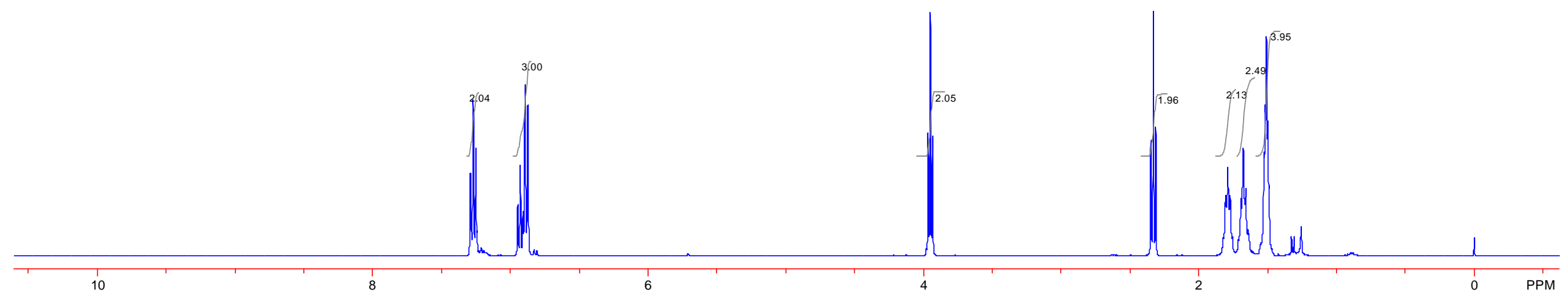


${ }^{13} \mathrm{C}$ NMR (100 MHz, CDCl3)
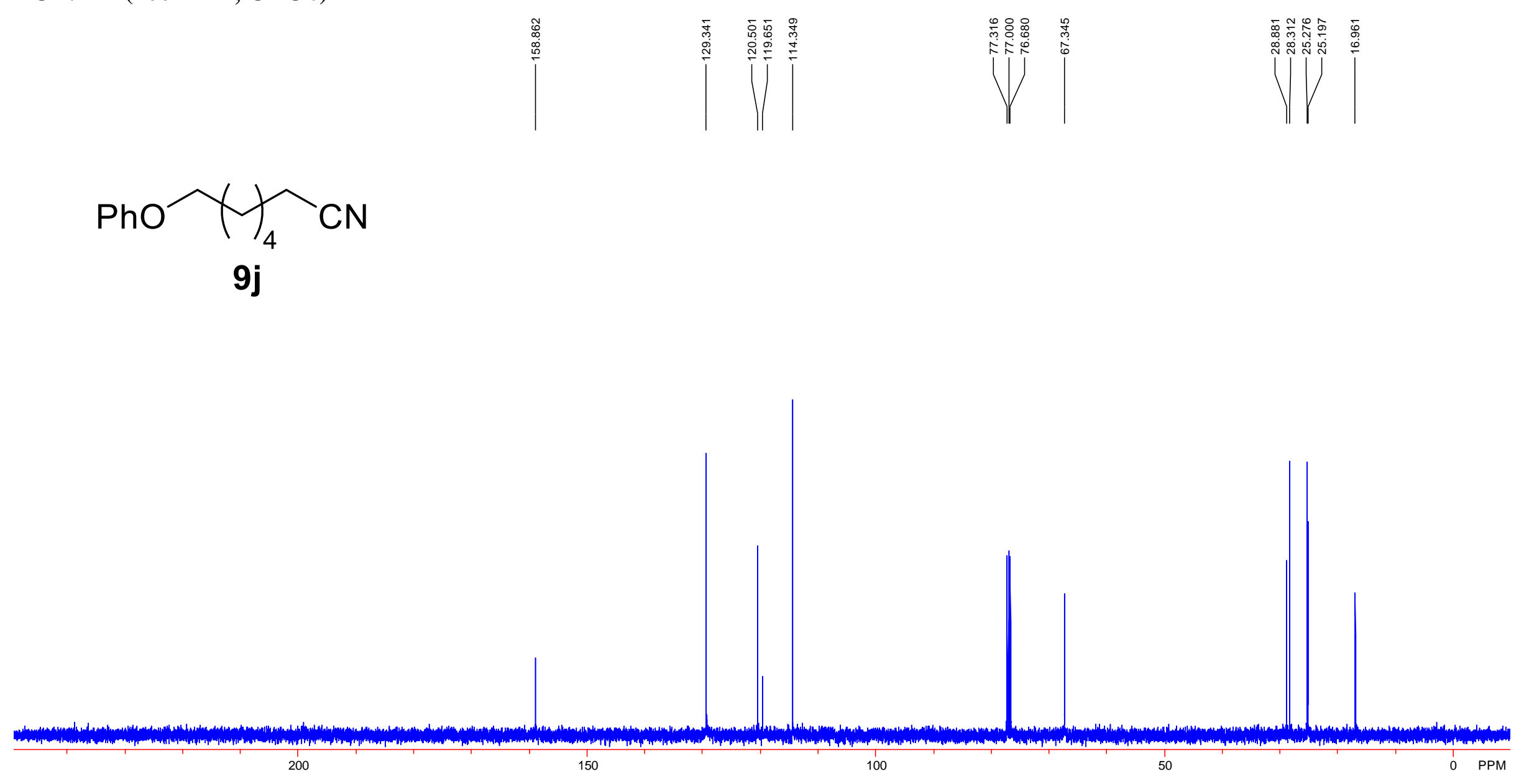
${ }^{1}$ H NMR (400 MHz, CDCl3)
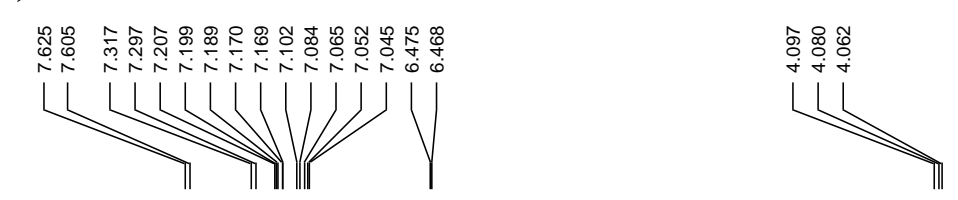

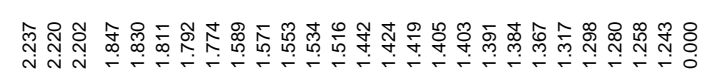
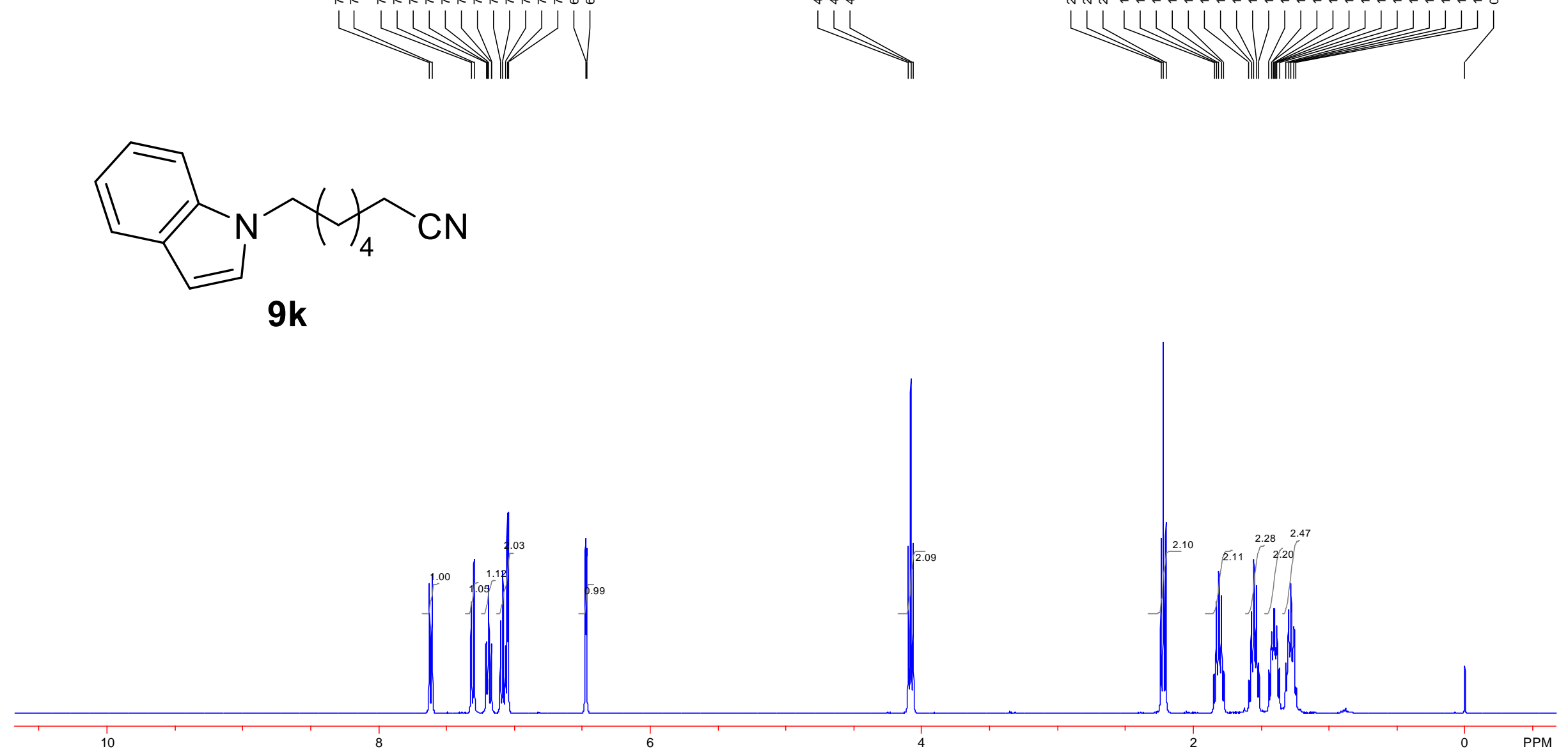
${ }^{13} \mathrm{C}$ NMR (100 MHz, CDCl3)
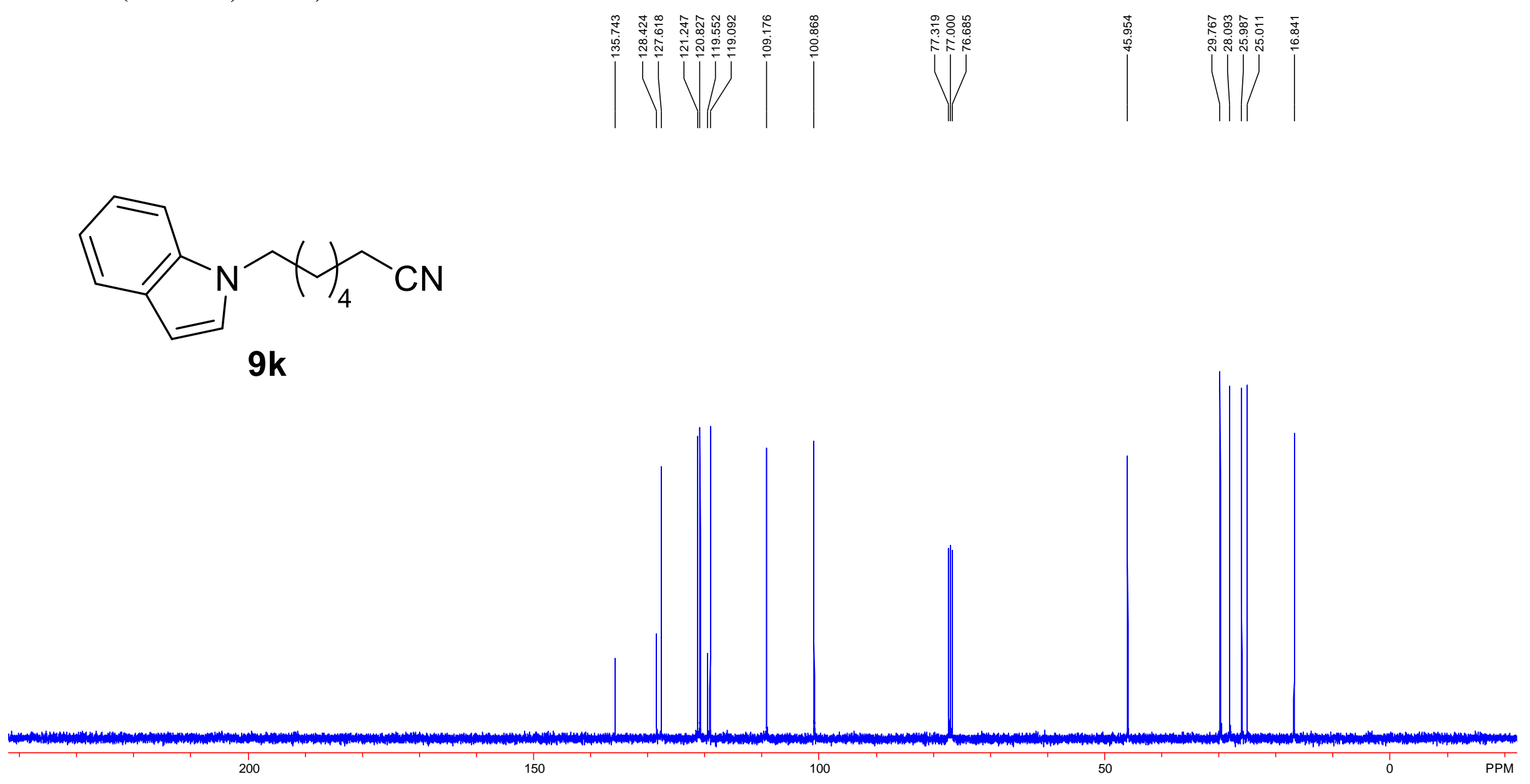
${ }^{1}$ H NMR (400 MHz, CDCl3)
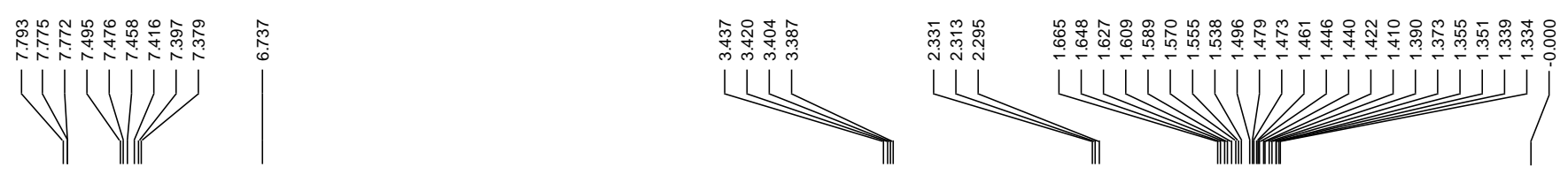<smiles>CC(C)(CC#N)CNC(=O)c1ccccc1</smiles>

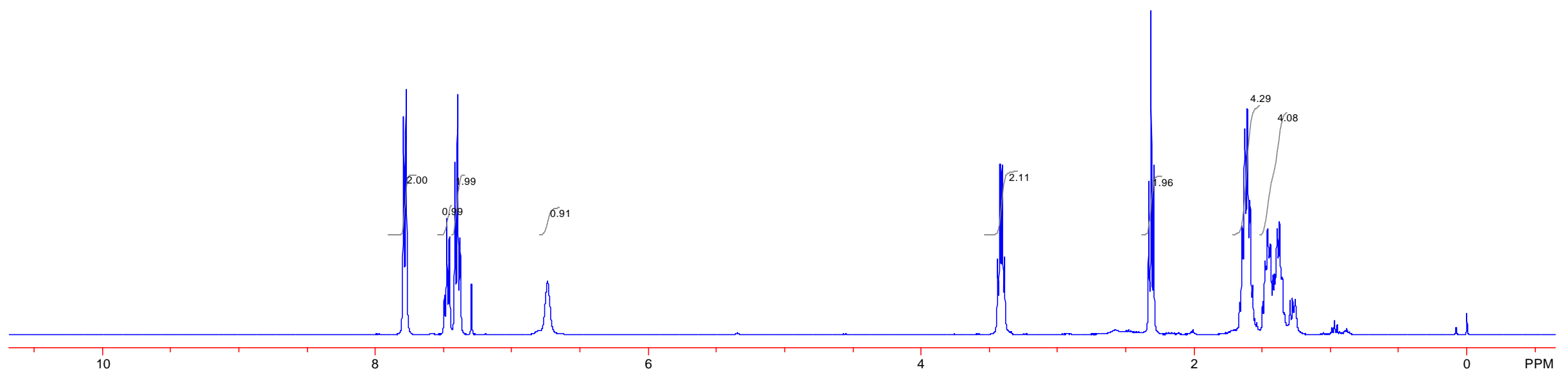


${ }^{13} \mathrm{C}$ NMR (100 MHz, CDCl3)

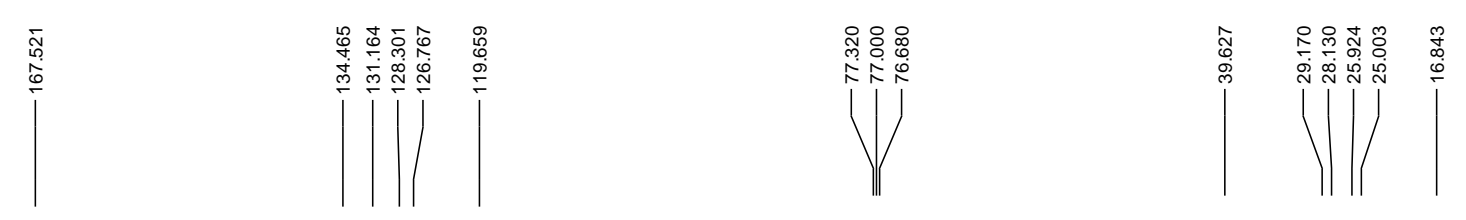<smiles>CC(C)(CC#N)CNC(=O)c1ccccc1</smiles>

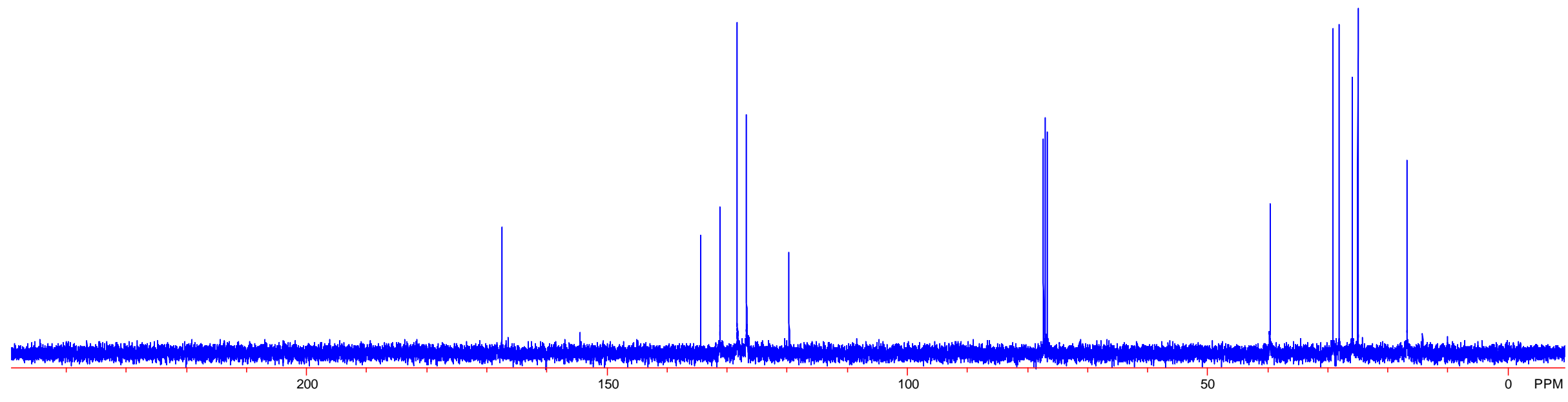

